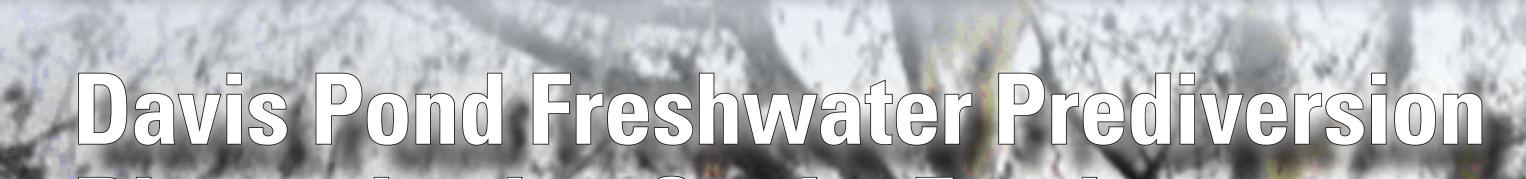

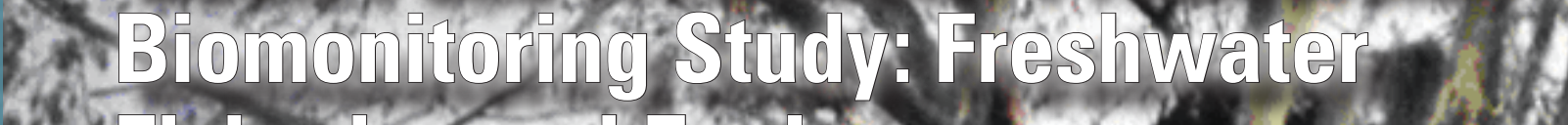

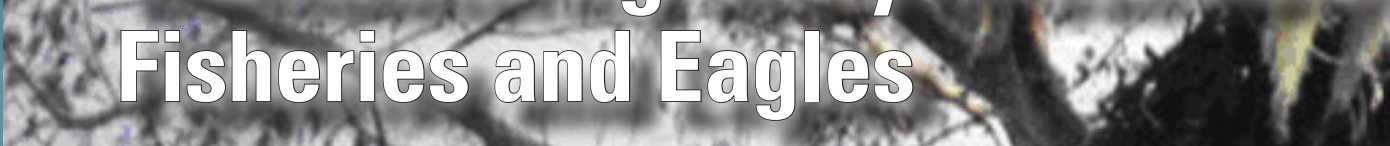
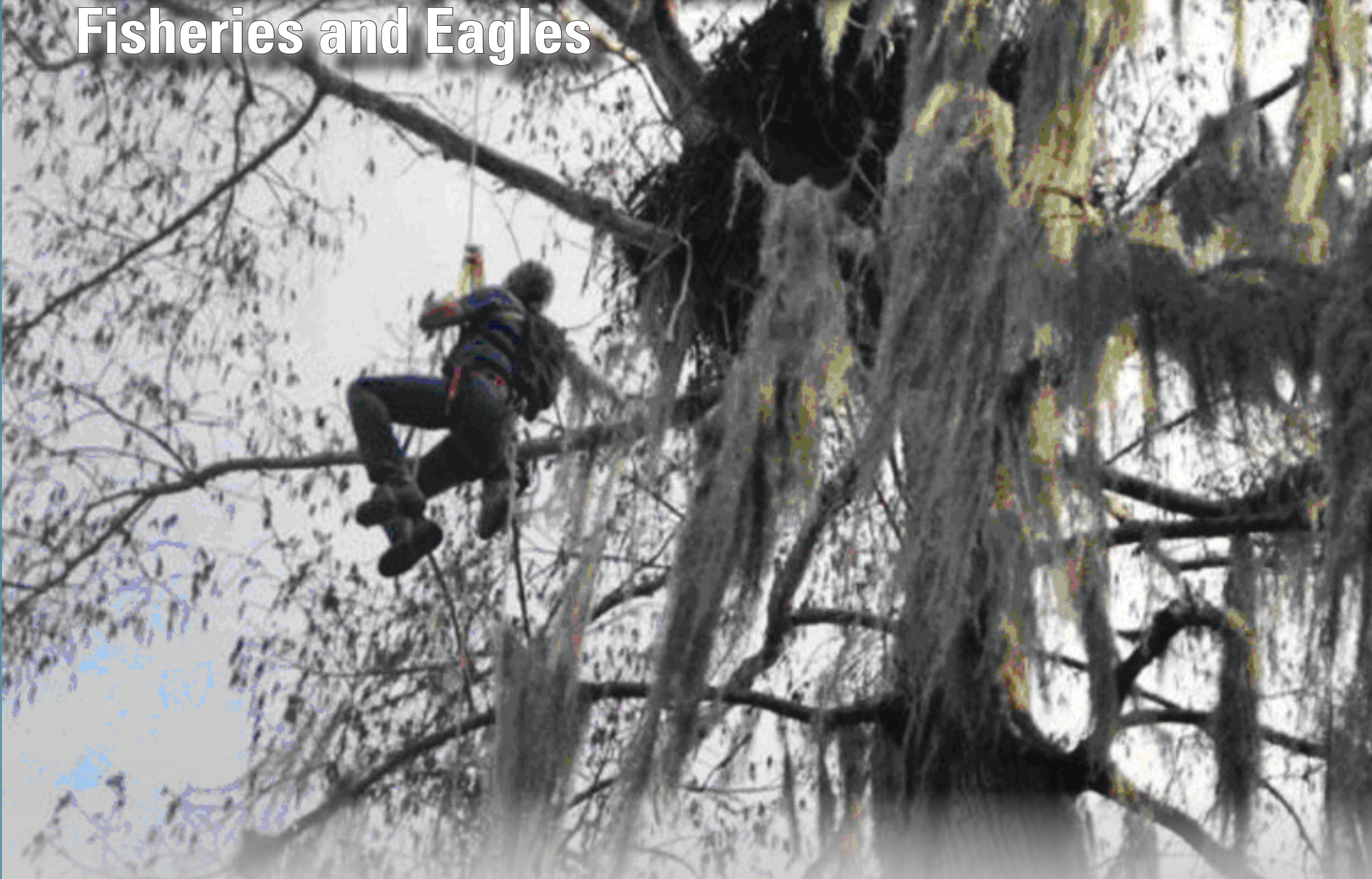

Scientific Investigations Report 2008-5067 
Cover photograph: A tree-climber scales a tree in the Davis Pond, La., area. Active bald eagle (Haliaeetus leucocephalus) nests were targeted for sampling eaglet blood. The site is near mile marker 75 on the Gulf Intracoastal Waterway. 


\section{Davis Pond Freshwater Prediversion Biomonitoring Study: Freshwater Fisheries and Eagles}

By Jill A. Jenkins, E. Beth Bourgeois, and Clint W. Jeske

Scientific Investigations Report 2008-5067 


\section{U.S. Department of the Interior DIRK KEMPTHORNE, Secretary}

\section{U.S. Geological Survey \\ Mark D. Myers, Director}

U.S. Geological Survey, Reston, Virginia: 2008

This and other USGS information products are available at http://store.usgs.gov/

U.S. Geological Survey

Box 25286, Denver Federal Center

Denver, C0 80225

To learn about the USGS and its information products visit http://www.usgs.gov/ 1-888-ASK-USGS

Any use of trade, product, or firm names is for descriptive purposes only and does not imply endorsement by the U.S. Government.

Although this report is in the public domain, permission must be secured from the individual copyright owners to reproduce any copyrighted materials contained within this report.

Suggested citation:

Jenkins, J.A., Bourgeois, E.B., and Jeske, C.W., 2008, Davis Pond freshwater prediversion biomonitoring study_freshwater fisheries and eagles: U.S. Geological Survey Scientific Investigations Report 2008-5067, 102 p. 


\section{Preface}

This report presents results, study interpretations, and background information regarding the biomonitoring survey for contaminants performed at the Davis Pond freshwater diversion project site in Louisiana. The overall purpose of this study was to evaluate potential impacts of the operations of the Davis Pond freshwater diversion structure on fish, bivalves, and eagles in the downstream marsh area. These data were collected in 2001, prior to full functioning of the diversion structure, and so are considered to have been obtained prediversion.

The monitoring plan closely examines the status of the freshwater fisheries and eaglets along with contaminant residues; interpretations of biological relevance are offered based on biomarker observations and literature. Contaminant values are provided for individual fish, composites of bivalve tissues, and eaglet blood samples, and comparisons were made from appropriate available literature, both recent and historical, to enhance understanding of the chemical data. Further, because biomarkers reflect the condition of animals and the habitat in which they reside, biomarker data were collected to add relevant information to the understanding of potential effects of contaminant stressors in or entering this ecosystem.

This study was conducted cooperatively by the U.S. Geological Survey, the Louisiana Department of Wildlife and Fisheries, the U.S. Army Corps of Engineers, and the U.S. Fish and Wildlife Service (USFWS). The study was designed in the mid-1990s through an interagency cooperative effort and is in accordance with a memorandum from the president of the Mississippi River Commission dated October 31, 1995: Flood Control of the Mississippi River and Tributaries, Mississippi Delta Region, Louisiana, Salinity Control Structures, Design Memorandum No. 1 - Davis Pond Freshwater Diversion Structure, Supplement No. 1 - Biological, Hydrologic, Water and Sediment Quality Monitoring Program. Specifics of this sampling design are in accordance with the initial USFWS 1984 biological opinion written by Dennis Jordan, then field supervisor of the USFWS Endangered Species Field Office, and the 1996 revision for the Davis Pond diversion as mandated by the Endangered Species Act of 1973.

Questions regarding this report should be directed to either of the following:

U.S. Fish and Wildlife Service

Ecological Services Field Office

646 Cajundome Blvd., Suite 400

Lafayette, LA 70506
J.A. Jenkins

U.S. Geological Survey

National Wetlands Research Center

700 Cajundome Blvd.

Lafayette, LA 70506 


\section{Contents}

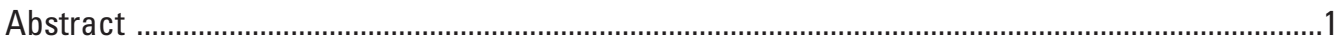

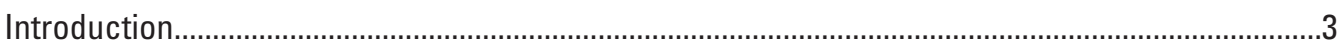

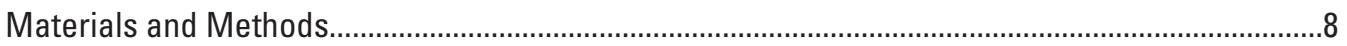

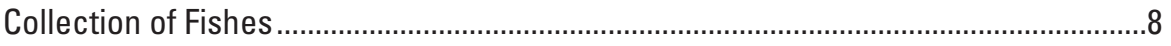

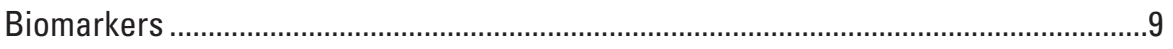

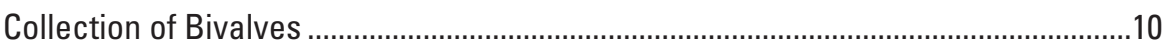

Collection of Eaglet Blood................................................................................... 10

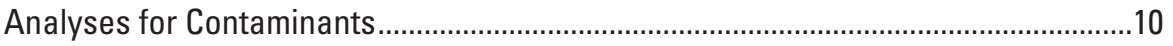

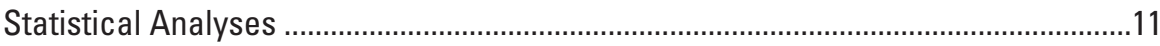

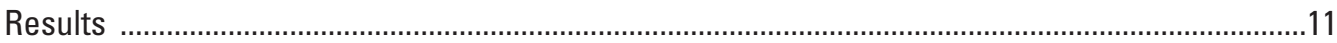

Graphics for Contaminants Analyses ……………………................................11

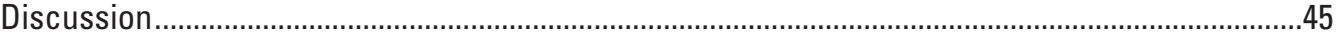

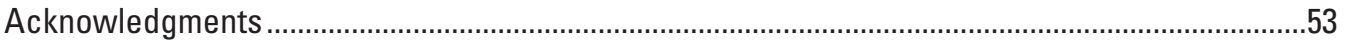

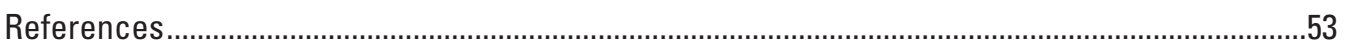

Appendix 1. Additional Tables and Figures............................................................................61

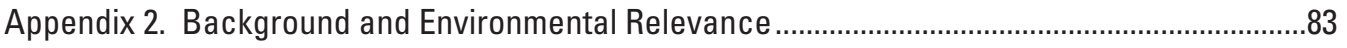

Appendix 3. Citations for Chemical Names and Abbreviations ......................................................93

\section{Figures}

1. Map showing locations of sampling sites for freshwater fish at the Davis Pond freshwater diversion in Louisiana

2. Map showing locations of sampling sites in the current study for fish along the Mississippi River in relation to the Caernarvon and Davis Pond freshwater diversions.

3. Graph of splenosomatic indices of fish.......................................................................

4. Microscopic image of blood cells from mullet ................................................................12

5. Graph of comparison of average percent white blood cells per site per species .............13

6. Micrographs of macrophage aggregates from fish spleens ...........................................13

7. Graph of frequency of macrophage aggregates per spleen by site ..................................14

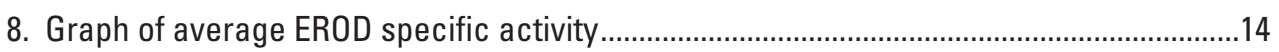

9. Graph and data table showing total organochlorines from aquatic animal tissues ..........16

10. Graph and data table showing total polycyclic aromatic hydrocarbons from

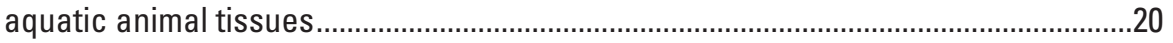

11. Graph showing percent white blood cells per fish versus BaP .......................................21

12. Graph and data table showing total aliphatic hydrocarbons from aquatic

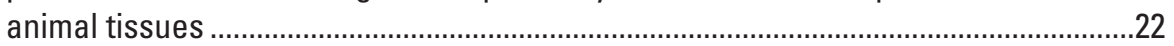

13. Graph and data table showing aluminum from aquatic animal tissues ..........................23

14. Graph showing aluminum, arsenic, barium, and zinc in eaglet whole blood ...................24

15. Graph and data table showing arsenic from aquatic animal tissues ...............................25

16. Satellite image showing EMAP Louisianian Province within Caernarvon and Davis Pond areas. 
17. Graph and data table showing barium from aquatic animal tissues ...............................28

18. Graph and data table showing boron from aquatic animal tissues ................................29

19. Graph and data table showing cadmium from aquatic animal tissues .............................30

20. Graph and data table showing chromium from aquatic animal tissues............................32

21. Graph and data table showing copper from aquatic animal tissues ...............................33

22. Graph showing copper, selenium, and silicon in eaglet whole blood................................34

23. Graph and data table showing iron from aquatic animal tissues.....................................35

24. Graph showing iron and sulfur in eaglet whole blood....................................................36

25. Graph and data table showing lead from aquatic animal tissues .....................................37

26. Graph showing lead, mercury, and strontium in eaglet whole blood ...............................38

27. Graph and data table showing magnesium from aquatic animal tissues.......................39

28. Graph showing calcium and magnesium in eaglet whole blood ......................................40

29. Graph and data table showing manganese from aquatic animal tissues ........................41

30. Graph and data table showing mercury from aquatic animal tissues..............................42

31. Graph and data table showing nickel from aquatic animal tissues ................................43

32. Graph and data table showing selenium from aquatic animal tissues.............................44

33. Graph and data table showing strontium from aquatic animal tissues .............................46

34. Graph and data table showing vanadium from aquatic animal tissues ...........................47

35. Graph and data table showing zinc from aquatic animal tissues.....................................48

\section{Tables}

1. Trace element ranges, geometric means, 85 th percentiles, and their dry weight equivalents from the National Contaminant Biomonitoring Program ...........................8

2. Range of detectable inorganic chemicals in aquatic animal tissues compared to values in NOAA Screening Quick Reference Tables (SQuiRTs) .....................................

3. Organochlorine concentrations per aquatic animal collected for study ............................17

4. Levels of organochlorines in eaglet whole blood ............................................................18

5. Ranges and geometric means of organochlorines from the National Contaminant Biomonitoring Program ...................................................................19

6. EMAP trace metals data from fillet composites from sampling stations within Caernarvon and Davis Pond areas........................................................................27

7. Levels of inorganic elements from eaglet blood ..........................................................31

8. Comparison of trace element ranges in fish and bivalves from Caernarvon and Davis Pond prediversion studies.

9. Nests and observations on food items 


\section{Conversion Factors}

\begin{tabular}{|c|c|c|}
\hline Multiply & By & To obtain \\
\hline \multicolumn{3}{|c|}{ Length } \\
\hline centimeter $(\mathrm{cm})$ & 0.3937 & inch (in.) \\
\hline meter $(\mathrm{m})$ & 3.281 & foot $(\mathrm{ft})$ \\
\hline kilometer $(\mathrm{km})$ & 0.6214 & mile $(\mathrm{mi})$ \\
\hline \multicolumn{3}{|c|}{ Volume } \\
\hline liter (L) & 33.82 & ounce, fluid (fl. oz) \\
\hline liter (L) & 61.02 & cubic inch $\left(\mathrm{in}^{3}\right)$ \\
\hline \multicolumn{3}{|c|}{ Mass } \\
\hline gram (g) & 0.03527 & ounce, avoirdupois (oz) \\
\hline kilogram $(\mathrm{kg})$ & 2.205 & pound avoirdupois (lb) \\
\hline
\end{tabular}

Temperature in degrees Celsius $\left({ }^{\circ} \mathrm{C}\right)$ may be converted to degrees Fahrenheit $\left({ }^{\circ} \mathrm{F}\right)$ as follows:

${ }^{\circ} \mathrm{F}=\left(1.8 \mathrm{x}^{\circ} \mathrm{C}\right)+32$

Specific conductance is given in microsiemens per centimeter at 25 degrees Celsius $(\mu \mathrm{S} / \mathrm{cm}$ at $\left.25^{\circ} \mathrm{C}\right)$. 


\title{
Davis Pond Freshwater Prediversion Biomonitoring Study: Freshwater Fisheries and Eagles
}

\author{
By Jill A. Jenkins, ${ }^{1}$ E. Beth Bourgeois, ${ }^{2}$ and Clint W. Jeske ${ }^{1}$
}

\section{Abstract}

In January 2001, the construction of the Davis Pond freshwater diversion structure was completed by the U.S. Army Corps of Engineers. The diversion of freshwater from the Mississippi River is intended to mitigate saltwater intrusion from the Gulf of Mexico and to lessen the concomitant loss of wetland areas. In addition to the freshwater inflow, Barataria Bay basin would receive nutrients, increased flows of sediments, and water-borne and sediment-bound compounds. The purpose of this biomonitoring study was, therefore, to serve as a baseline for prediversion concentrations of selected contaminants in bald eagle (Haliaeetus leucocephalus) nestlings (hereafter referred to as eaglets), representative freshwater fish, and bivalves. Samples were collected from January through June 2001. Two similarly designed postdiversion studies, as described in the biological monitoring program, are planned.

Active bald eagle nests targeted for sampling eaglet blood $(n=6)$ were generally located southwest and south of the diversion structure. The designated sites for aquatic animal sampling were at Lake Salvador, at Lake Cataouatche, at Bayou Couba, and along the Mississippi River. Aquatic animals representative of eagle prey were collected. Fish were from three different trophic levels and have varying feeding strategies and life histories. These included herbivorous striped mullet (Mugil cephalus), omnivorous blue catfish (Ictalurus furcatus), and carnivorous largemouth bass (Micropterus salmoides). Three individuals per species were collected at each of the four sampling sites. Freshwater Atlantic rangia clams (Rangia cuneata) were collected at the downstream marsh sites, and zebra mussels (Dreissena spp.) were collected on the Mississippi River.

The U.S. Geological Survey (USGS) Biomonitoring of Environmental Status and Trends (BEST) protocols served as guides for fish sampling and health assessments. Fish are useful for monitoring aquatic ecosystems because they accumulate pesticides and other contaminants. Biomarker data on individual fish, generated at the USGS National Wetlands Research Center (Lafayette, La.), included percent white blood cells in whole blood, spleen weight to body weight ratio, liver weight to body weight ratio, condition factor, splenic macrophage aggregates, and liver microsomal 7-ethoxyresorufin-o-deethylase (EROD) activity. Fish age was estimated by comparing total lengths with values from the same species in the Southeast United States as determined from the literature. Contaminant analyses were coordinated by the U.S. Fish and Wildlife Service (USFWS) Analytical Control Facility (Laurel, Md.), where residues of organochlorine (OC) pesticides, total polychlorinated biphenyls (PCBs), polycyclic aromatic hydrocarbons (PAHs), aliphatic hydrocarbons (AHs), and trace elements were determined. The organic contaminant data were generated at the Mississippi State University Chemical Lab (Mississippi State, Miss.), and the inorganic contaminant data were generated by the Texas A\&M University Geochemical and Environmental Research Group (College Station, Tex.). Statistical tests were performed to assess relationships among contaminants, fish age, fish species, and collection sites.

Trends in interspecific differences among fish in concentrations of contaminants were noted. Striped mullet (hereafter mullet) frequently displayed the highest chemical concentrations. Levels of contaminants were generally higher in samples obtained from the Mississippi River than in those collected from the diversion area and were higher in mussels and clams (hereafter bivalves) than in fish. Because the Mississippi River sampling site for mullet and largemouth bass was downriver of the structure and south of New Orleans and the catfish site was upriver, the downriver data may not be directly reflective of the results from the receiving waters at the Davis Pond structure. Compared to the Caernarvon freshwater prediversion study in 1990 that assessed possible influx of contaminants with the freshwater diversion, contaminant levels in fishes and bivalves in this study were generally lower, yet three nontoxic inorganic elements in Davis Pond fish samples exhibited ranges of concentrations that were more than two times higher than did those from Caernarvon. Levels in bivalves were different between diversions but about equal in the numbers of trace elements showing high levels per location. Contaminant values were

${ }^{1}$ U.S. Geological Survey.

${ }^{2}$ National Oceanic and Atmospheric Administration National Marine Fisheries Service. 
compared to those listed in various literature and agency sources, both regional and national, including the National Contaminant Biomonitoring Program (NCBP), in which the 85th percentile and above represents what is considered to be an elevated contaminant concentration and cause for concern.

Generally, bivalves were at the high end of their ranges for both organic and inorganic contaminants. In this study, OCs were detectable in 67 percent of fish from the Mississippi River site, ranging from 0.15 to $1.09 \mu \mathrm{g} / \mathrm{g}$ wet weight (ww) or fresh weight (fw), and in 11 percent of the fish from the marsh sites, ranging from 0.06 to $0.612 \mu \mathrm{g} / \mathrm{g}$ ww. Bivalves from the Mississippi River had OC levels of $0.096 \mu \mathrm{g} / \mathrm{g} \mathrm{ww}$, whereas none were detectable in bivalves at the marsh sites. In this study, $p, p$ '-dichlorodiphenyldichloroethylene ( $p, p$ 'DDE) (a biodegradation product of DDT [dichlorodiphenyl trichloroethane]) and total PCBs were the most frequently detected OCs and were primarily from the Mississippi River. For total OC content, using adjusted least squares means, some significant interactions were noted between fish species and sites. PAHs were detected in aquatic animals at all sites (range of 0.017-17.534 $\mu \mathrm{g} / \mathrm{g} \mathrm{ww}$ ), as were AHs (range of 0.423-4.549 $\mu \mathrm{g} / \mathrm{g} w \mathrm{w})$; the highest levels of PAHs and AHs were found in bivalves from the Mississippi River. When analysis of variance $(\alpha=0.05)$ was performed with data from aquatic animals, there were only two significant relationships between PAHs, AHs, and OCs between species, site, and age or the interaction among these variables. There was an interaction between fish species and n-decane (an $\mathrm{AH}$ ) in that mullet and largemouth bass had significantly higher levels than did catfish $(P=0.0175)$.

When general linear means were used to investigate associations of inorganic contaminants among fish species, site, and age or any interactions among these variables, no significant results were noted for arsenic, cadmium, lead, beryllium, boron, molybdenum, or nickel. The range of mercury in fish in this study was $0.04-0.14 \mu \mathrm{g} / \mathrm{g}$ ww $(0.14$ $0.48 \mu \mathrm{g} / \mathrm{g}$ dry weight [dw]), with the most elevated levels detected in predatory largemouth bass at the sampling point farthest downstream from the structure and within the marsh area. Mercury was positively correlated with fish age $(P=$ 0.0152 ), where levels were estimated to increase 0.0253 parts per million (ppm) dw per year. In the Mississippi River, catfish showed significantly higher levels of mercury than did mullet or largemouth bass $(P=0.00167)$.

Among fish species, mullet displayed the highest levels in fish of aluminum, barium, manganese, and iron, all considered to have low toxicity in hydrologic systems. An interaction between fish and site was seen with aluminum $(P=0.0031)$, where concentrations in mullet were significantly higher in the Mississippi River than at the other sites, as was also seen with barium $(P=0.0009)$, chromium $(P=<0.0001)$, manganese $(P=0.0004)$, strontium $(P=0.0074)$, vanadium $(P=0.0156)$, and zinc $(P=0.0059)$. For iron $(P=0.0 .0001)$, mullet and largemouth bass at both the Mississippi River and Lake Salvador showed higher levels than did catfish, and these two species showed higher levels at two of the four sites. An interaction between fish and site was also seen with chromium $(P=<0.0001)$ in that concentrations in mullet were significantly higher in the Mississippi River than at the other sites, as was also seen with strontium $(P=0.0074)$, vanadium $(P=0.0156)$, and zinc $(P=0.0059)$, metals for which deleterious effects have been demonstrated in other ecosystems. The NCBP program lists the 85th percentile for zinc at $34.2 \mu \mathrm{g} / \mathrm{g}$ fw $(117.9 \mu \mathrm{g} / \mathrm{g} \mathrm{dw})$. In the Davis Pond prediversion biomonitoring study (hereafter the current study), one fish (MUL31RIVER, fish ID 8) showed values higher than that $(125.4 \mu \mathrm{g} / \mathrm{g} \mathrm{dw}$ or $37.54 \mu \mathrm{g} / \mathrm{g} \mathrm{ww})$, and the Mississippi River bivalve sample (MUSSRIVER) had a value of $140 \mu \mathrm{g} / \mathrm{g}$ $\mathrm{dw}(41.2 \mu \mathrm{g} / \mathrm{g} \mathrm{ww})$.

In the current study, approximately 86 percent of the fish had measurable selenium levels, yet none reached the 85 th percentile. The 85 th percentile for selenium from the NCBP was $0.73 \mu \mathrm{g} / \mathrm{g}$ ww. Significantly higher levels of selenium were seen in mullet than in largemouth bass and catfish $(P=0.0023)$. The NCBP 85 th percentile for lead is $0.22 \mu \mathrm{g} / \mathrm{g}$ ww $(0.76 \mu \mathrm{g} / \mathrm{g} \mathrm{dw})$. In the current study, the range of concentrations of lead was as much as $18.3 \mathrm{ppm}$ dw (MUL31RIVER, fish ID 8), with the three most elevated values (range of 3.46-5.31 $\mu \mathrm{g} / \mathrm{g} \mathrm{ww}$ ) coming from mullet from the Mississippi River.

Biomarker data are measurable and directly reflect the condition of the animal, and measuring more than one biomarker in an individual increases confidence in health assessments. In the current study, biomarkers included macrophage aggregates (MAs), liver (hepatosomatic index [HSI]) and spleen (splenosomatic index [SSI]) weight to body weight ratios, percent white blood cells (WBCs) in whole blood, and condition factor. Few significant differences were noted with any of the biomarkers between sites, and there were no relationships between species and sites. For improved use of biomarker assessments, an increase in fish sample size would be useful for postdiversion sampling, as would comparisons of fish of the same sex and reproductive condition.

During the current study, success for eagle nests in the diversion area and reference sites was similar as determined by numbers of nestlings fledged. When temperatures were below average during winter 2000, nests in both regions similarly failed. At each nest, the primary evidence of food items was small mammals. Eaglets $(n=6)$ generally appeared healthy, and whole blood concentrations of organic contaminants exceeded detection limits with three incidences of $p, p^{\prime}$-DDE $(0.002-0.006 \mu \mathrm{g} / \mathrm{L} \mathrm{ww})$ and one incidence of oxychlordane $(0.002 \mu \mathrm{g} / \mathrm{L} w \mathrm{w})$. The levels of $p, p$ '-DDE were well below those that have been inversely correlated with productivity and success rates of nesting bald eagles on a regional scale. The low values found in the whole blood samples for OC pesticides and PCBs were even lower when corrected for plasma volume. Aluminum values were 3.66 and $5.75 \mu \mathrm{g} / \mathrm{L}$ in two samples, zinc ranged from 5.21 to $6.77 \mu \mathrm{g} / \mathrm{L} \mathrm{ww}$ in six samples, and silicon ranged from 1.7 to $4.6 \mu \mathrm{g} / \mathrm{L}$ in four samples. Selenium was detectable in each bird with the range 
at $0.332-0.566 \mu \mathrm{g} / \mathrm{L} w \mathrm{w}$, and strontium ranged from 0.0581 to $0.0975 \mu \mathrm{g} / \mathrm{L}$ ww. Mercury was detectable in blood samples from each bird and ranged from 0.0254 to $0.0845 \mu \mathrm{g} / \mathrm{L}$ ww, whereas lead was detectable in four samples and ranged from 0.0042 to $0.0136 \mu \mathrm{g} / \mathrm{L}$ ww. Although no detectable levels of total PCBs were found (also correlated with decreased reproductive productivity), 70 percent of the aquatic animals from the Mississippi River contained total PCBs (range $0.13-0.79 \mu \mathrm{g} / \mathrm{L}$ ), whereas only about 7 percent of the aquatic animals sampled from the marsh area contained PCBs.

Suggestions for postdiversion sampling include lowering the analytical detection limit for some metals, sampling aquatic animals over the course of a single season, obtaining a higher sample number of mature fish of one species (for example, blue catfish) within a range of total lengths for biomarker analyses, obtaining otoliths for estimating fish ages, assessing dioxins in eaglet blood, examining triazines in water, and obtaining all Mississippi River fish samples as close to the Davis Pond structure intake as possible. Because contaminants found in blood of eaglets reflect their prey species and because of the contaminant levels found in fish in the current study, eaglets may not be consuming primarily these species; therefore, obtaining juvenile nutria (Myocastor coypus) or turtle species for contaminant analyses might be considered, as well as collecting greater blood volume and using plasma to measure OCs and PCBs. Data obtained postdiversion will be compared with prediversion data to monitor changes.

Keywords: bald eagle, Barataria Bay, Bayou Couba, biomarkers, bivalves, blue catfish, Caernarvon, contaminants, Davis Pond, freshwater diversion, Lake Cataouatche, Lake Salvador, largemouth bass, Louisiana, Mississippi River, striped mullet.

\section{Introduction}

In January 2001, construction of the Davis Pond freshwater diversion structure in southeastern Louisiana was completed by the U.S. Army Corps of Engineers (USACE). The construction was authorized under the Flood Control Act of 1965 (Title II of Public Law 89-298), the Water Resources Development Act of 1974 (Title I of Public Law 93-251), and the Water Resources Development Act of 1986 (Public Law 99-662) through the Mississippi Delta Region Project to achieve suitable salinity gradients and temperature requirements for indigenous species. The diversions of freshwater from the Mississippi River are intended to alleviate saltwater intrusion from the Gulf of Mexico and to lessen loss of wetland areas in southeastern Louisiana; nutrients, sediments, and waterborne and sediment-bound compounds are diverted along with the freshwater into the Barataria Bay basin.

The purpose of this prediversion biomonitoring study (hereafter referred to as the current study) was to collect data on the concentrations of selected contaminants in resident representative freshwater fish and bivalves and in eaglets. Samples were collected from January through June 2001. Two similar postdiversion studies are planned (U.S. Army Engineer District, 1995).

The Davis Pond project site is in the Lake Cataouatche area and along the west bank of the Mississippi River in St. Charles Parish, La. (figs. 1 and 2). Operation of the structure is intended to imitate historical spring floods to provide a controlled flow of freshwater and nutrients from the Mississippi River into a target area in the Barataria Bay basin. The target salinity level is approximately 15 parts per thousand (ppt) in the middle of the basin, and the project would be active for about 50 years.

In this report, we also present comparison data from Conzelmann and others (1996) on the Caernarvon freshwater diversion. The Caernarvon freshwater diversion structure, completed in 1991 and located south of New Orleans on the east bank of the Mississippi River near the boundary of St. Bernard and Plaquemines Parishes, La., is where Mississippi River water is diverted into the Breton Estuary. This structure became partially operative in 1992. Similar to the Davis Pond diversion, the objectives were to enhance nourishment of emergent marsh vegetation, reduce marsh loss via increase in sedimentation, and enhance productivity of fisheries and wildlife. Conzelmann and others (1996) presented data from two prediversion and two postdiversion samplings at the Caernarvon site, and these results offer comparisons with those presented in this report.

The U.S. Fish and Wildlife Service (USFWS) provides oversight of the Davis Pond diversion through the Endangered Species Act of 1973 (Public Law 93-205; 87 Stat. 884, as amended; 16 U.S.C. 1531 et seq) for endangered and threatened species, formerly including the bald eagle (Haliaeetus leucocephalus). Bald eagles were officially removed from the List of Endangered and Threatened Species as of August 8, 2007, but they are protected by the Bald and Golden Eagle Protection Act (54 Stat. 250, as amended, 16 U.S.C. 668a-d) and the Migratory Bird Treaty Act (40 Stat. 755, as amended; 16 U.S.C. 703-712.). Because of their status, eagles and their supportive fisheries (for example, fish and bivalves) were the focal points of this study.

Rates of nesting successes of raptor populations can inform managers of the level of reproductive success that might be expected under optimal conditions (Anthony and others, 1994), but several factors may influence eagle health and productivity. Changes in water levels, water chemistry, and salinity may impact nesting habitat (Dugoni, 1980). Concentrations of contaminants in blood reflect nestling exposure to these compounds from their prey, and effects of environmental contaminants on bald eagle productivity have been well studied (Wiemeyer and others, 1984, 1993; Frenzel and Anthony, 1989; Grubb and others, 1990; Bowerman and others, 2003). There have been regional resurgences of bald eagle populations in North America (Colborn, 1991), despite concentrations of $p, p^{\prime}$-dichlorodiphenyldichloroethylene ( $p, p^{\prime}$ - 


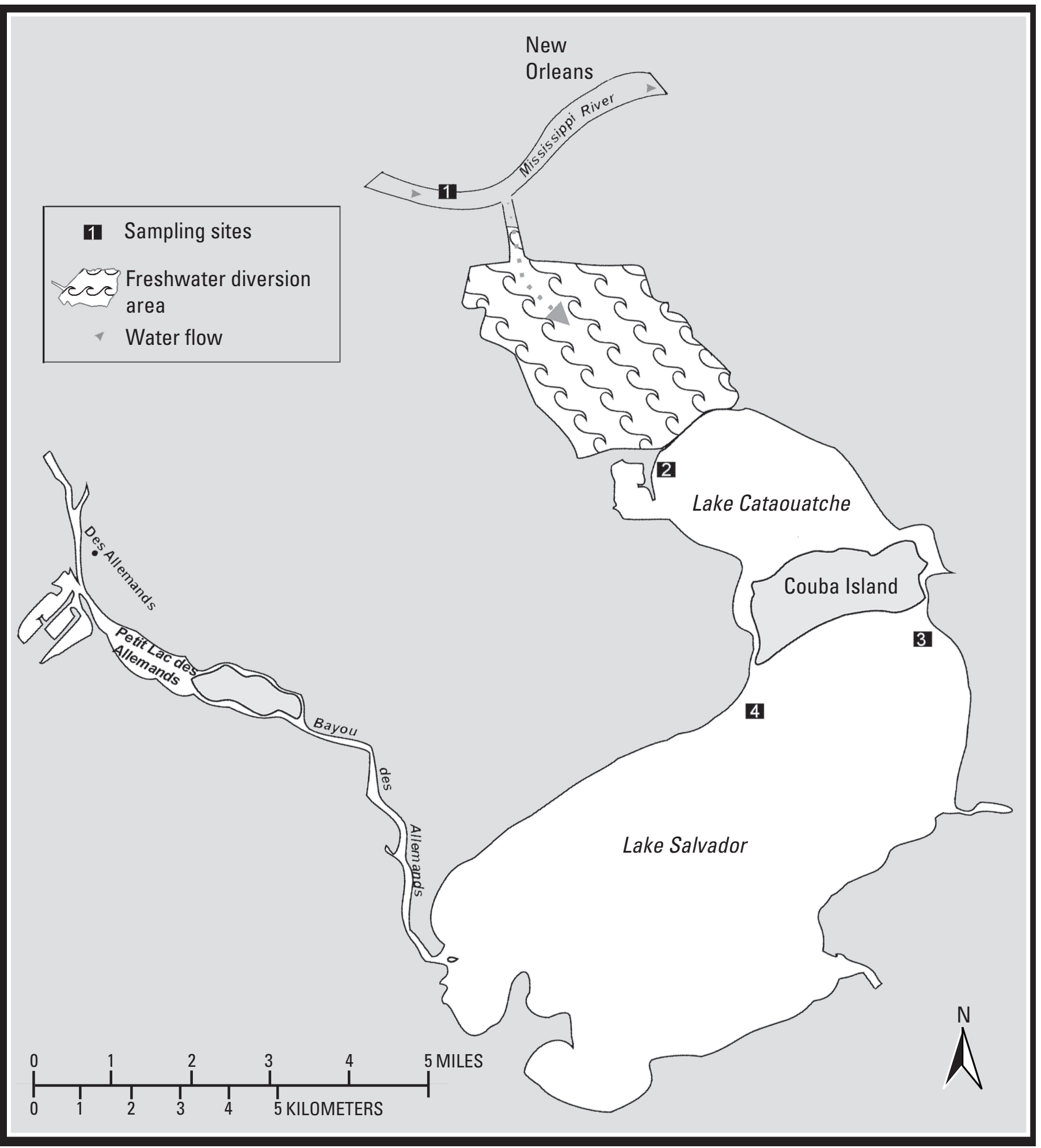

Figure 1. Locations of sampling sites for freshwater fish at the Davis Pond freshwater diversion in Louisiana. Sites include site 1 at the Mississippi River, site 2 at Lake Cataouatche, site 3 at Bayou Couba, and site 4 at Lake Salvador. Sampling of sites for eaglets was generally performed south and west of the structure. For background information, images, and maps, refer to http://www.mvn.usace. army.mil/pao/dpond/davispond.htm. 


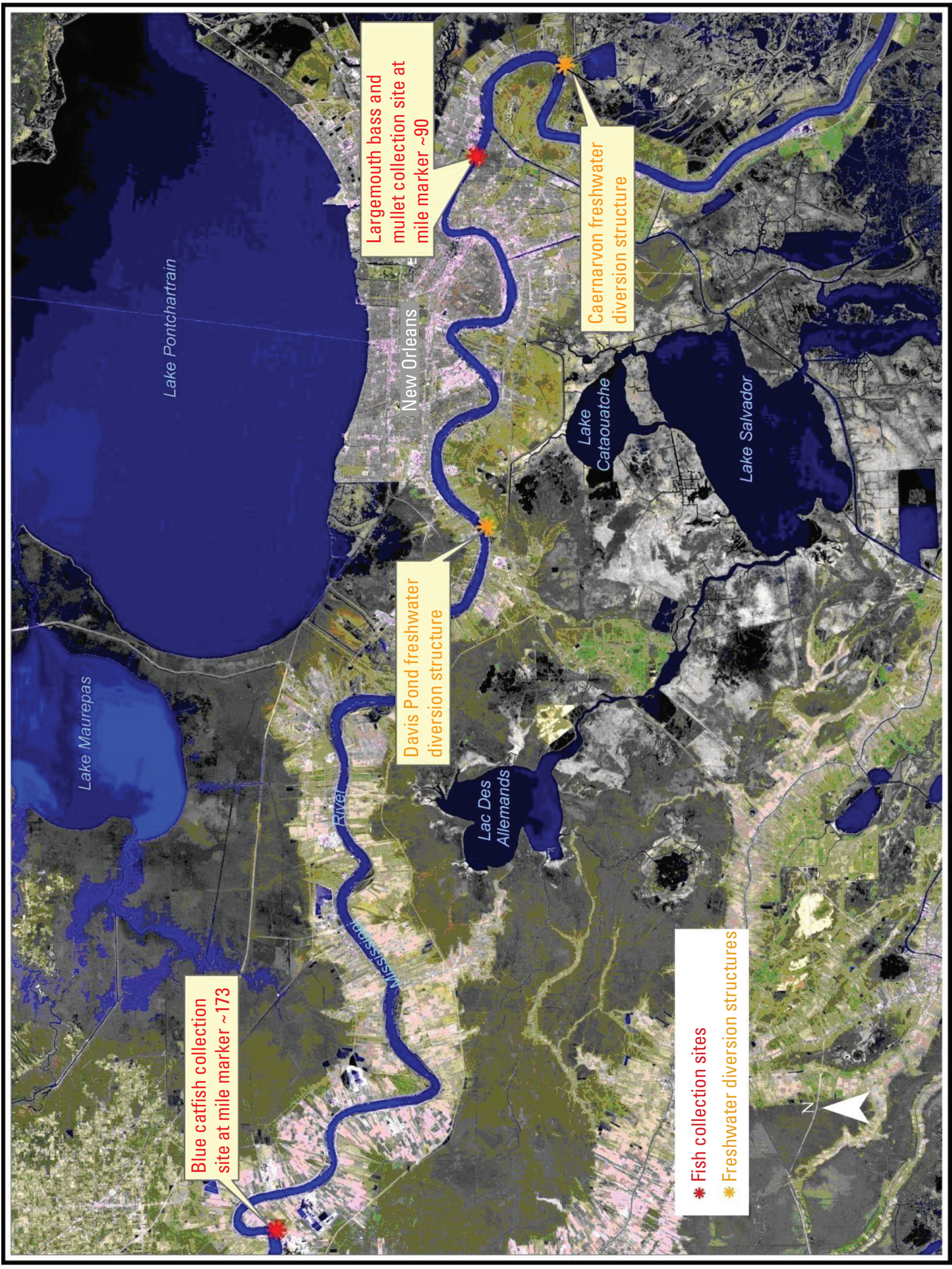

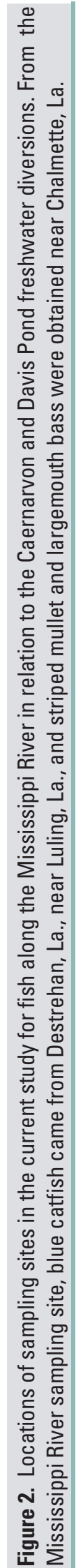


DDE) (Wiemeyer and others, 1984) and total polychlorinated biphenyls (PCBs) in blood from eaglets that are linked to reductions in productivity (total number of fledged young per occupied nest) and success rates (percent of nests producing at least one fledged young) of nesting bald eagles (Bowerman and others, 2003). The most sensitive functional endpoint for PCB- and dioxin-mediated toxicity is reproductive impairment (Hoffman and others, 1996). Fish and small animals are primary food sources for eagles. The primary route of their exposure to contaminants is by prey consumption. The Food and Drug Administration regulates tolerances of PCBs in foods and feeds; the tolerance for fish is 2.0 parts per million (ppm) in fish and shellfish (edible portions) (National Toxicology Program, 2002). In the current study, contaminant levels were directly measured in whole blood of eaglets sampled from the pond area and a reference site, from whole bodies of fish species considered prey items, and from composites of bivalve tissues from the pond area and a reference site.

Bald eagle nesting territories near the Davis Pond structure are in the vicinity of Lake Cataouatche, St. Charles Parish, and Lafitte, Jefferson Parish. Nests are in large trees, often old growth timber, near coastal areas, lakes, and rivers and are rarely found in areas of heavy human use. Eagles use the same nest yearly, or if it is blown down, they build another nearby. Nesting territories are approximately $5.2 \mathrm{~km}^{2}$. Bald eagles have been observed nesting successfully at 4 years of age, but most do not breed until at least their fifth year. Breeding pairs remain together as long as both are alive. In the Southeastern United States, eggs are laid from winter to late spring (Dugoni, 1980). Squirrels, ravens, and gulls are known to break and eat egg contents. Eagles lay one clutch per year, yet if the clutch is lost, a replacement clutch may be laid (Buehler, 2000). Young fledge at about 10-12 weeks of age but return to the nest for food for several weeks. Successful breeding depends on weather conditions, food abundance, and habitat. Sometimes two eaglets will survive, but it is not uncommon for the larger eaglet to kill its sibling.

During the current study, no eggs were produced in the 2000 breeding season; the average temperature for the months of November through January was $57.6^{\circ} \mathrm{C}$, which was below normal, and there was a regional drought (climate data from the National Oceanic and Atmospheric Administration [NOAA]). Therefore, eaglet clutches from 2001 were sampled from eagle nests in the diversion area and reference sites for the current study. Aerial surveys allowed the assessment of nest locations, and trees were climbed to handle eaglets for blood sampling. Climbing trees to band young and capture breeding adults for radiotelemetry has been found to have no apparent adverse effect on occupancy of nest sites or nesting success of bald eagles (Anthony and others, 1994).

Dugoni (1980) performed an ecological and biological study from 1977 to 1980 of nesting bald eagles in southcentral and southeastern Louisiana, through which food habits and organochlorine (OC) residues were evaluated for some major prey species. Bald eagle nests were primarily located in permanently or annually flooded swamps composed of baldcypress (Taxodium distichum) and tupelogum (Nyssa biflora) and mixed hardwoods commonly found along the back slopes of former deltaic distributaries and near water bodies. Out of 10 active nests, remains of prey were composed of 42.3 percent birds, 41.6 percent fish, 15.7 percent mammals, and 0.4 percent reptiles. American coots (Fulica americana) and catfish (Ictalurus spp.) composed 42.0 percent of the diet. Of the avian species, American coots made up 48 percent of the prey items. Of the fish, equal numbers of bowfin (Amia calva), freshwater drum (Aplodinotus grunniens), and striped mullet (Mugil cephalus) made up 29.7 percent of that total fish percentage. Muskrat (Ondatra zibethicus) and nutria (Myocastor coypus), both aquatic mammals, accounted for 84.2 percent of mammals identified. Fish from shallow waters and carrion were noted as being important in eagle foraging. In St. Mary and St. Tammany Parishes, the frequency of Aroclor 1254, a common PCB, was detected at a 68 percent occurrence rate in prey items, and $p, p$ '-DDE and dieldrin occurred in 55 percent and 50 percent of the samples, respectively. Bioaccumulation of DDT has led to eggshell thinning in fish-eating birds, including the bald eagle (Schmitt and Bunck, 1995). Organochlorines were detected in 86 percent of the prey in the 1980 study (Dugoni, 1980), but no concentrations exceeded $0.297 \mu \mathrm{g} / \mathrm{g}$ ww.

In the current study, the designated sampling sites for aquatic animals were located at Lake Salvador, at Lake Cataouatche, at Bayou Couba, and along the Mississippi River (figs. 1 and 2). The animals sampled were selected for the current study because they represented three ecological niches. Striped mullet (hereafter mullet) are herbivores that feed on plankton, small algae, and detritus, thereby often consuming sediment. Blue catfish (Ictalurus furcatus; hereafter catfish) are omnivores, and largemouth bass (Micropterus salmoides) are carnivores that feed in the water column and consume aquatic insects and fish (bluegill [Lepomis macrochirus], American gizzard shad [Dorosoma cepedianum], and threadfin shad [Dorosoma petenense]) (U.S. Fish and Wildlife Service, 1983; Ross, 2001). Freshwater bivalves are benthic invertebrates that obtain food by filter feeding and are consequently exposed to contaminants that are dissolved in water, associated with suspended particles, and deposited in bottom sediments (Naimo and others, 1992). Freshwater Atlantic rangia clams (Rangia cuneata) were collected at the downstream sites, and zebra mussels (Dreissena spp.) were collected on the Mississippi River. General fish health and morphological measurements were recorded, and blood, spleens, and livers were collected according to the USGS Biomonitoring of Environmental Status and Trends (BEST) protocols (Schmitt, 2002). Individual fish, composite bivalve meats, and eaglet whole blood were appropriately stored and frozen at $20^{\circ} \mathrm{C}$ until overnight mailing to laboratories for contaminants analyses.

In ecotoxicological studies, the impact of pollutants can be assessed by the use of bioindicator data (biomarkers) which reflect different levels of ecological relevance (Adams, 2002). 
Therefore, biomarkers from individual fish were measured in attempts to interpret possible stressor impacts to physiological parameters. Two important features of biomarkers are the ability to detect interactions between stressors and organisms and the capability to quantify sublethal effects. Biomarkers reflect chemical exposures and can integrate many of the physical, chemical, and biological stressors that operate in aquatic ecosystems (Adams, 2002). Biomarker analyses assist in measuring effects of highly toxic chemicals and of those that do not accumulate in fish and wildlife prior to reaching harmful levels. For ecological risk assessments (the process for assessing magnitudes and probabilities of the adverse effects of human activities), some of the most valuable biomarkers have been phase I liver enzymes, biotransformation products (such as biliary PAH metabolites), reproductive parameters, and genotoxic parameters (van der Oost and others, 2003). In the current study, although fish were of different ages, sex, and reproductive maturities, biomarker measurements were taken. Biomarkers included spleen to body weight ratio (splenosomatic index [SSI]), liver to body weight ratio (hepatosomatic index [HSI]), white blood cell (WBC) counts from whole blood, macrophage aggregates (MAs) from spleens, and liver microsomal 7-ethoxyresorufino-deethylase (EROD) activity that reflects metabolism of xenobiotics.

For the current study, we also applied condition factor, an index of fish health based on length and weight that can be influenced by fish age, sex, stage of maturation, nutrients, amount of fat reserve, and degree of muscular development, as well as season (Zugarramurdi and others, 2003). Body condition indices such as the condition factor-commonly used in fisheries biology — can be useful in situations in which a wide range of conditions is expected (Sutton and others, 2000).

Organosomatic indices (ratios of organ weight to body weight), which have been used in a number of stress assessment studies (Goede and Barton, 1990; Barton and others, 2002), were also employed in the current study. The assumption is that lower than normal gonadosomatic index (GSI) and HSI indicate a diversion of energy away from organ or tissue growth and toward combating a stressor. The HSI is the most frequently used organ-to-mass ratio (Goede and Barton, 1990). The liver serves as a major storage site for glycogen; therefore, the HSI can provide an indication of the nutritional state of the fish. Some HSI values have been shown to decrease in fish stressed by adverse changes in water quality (Lee and others, 1983), by altered water flows (Barnes and others, 1984), and by repeated handling (Barton and others, 1987). The HSI values can increase after exposure to certain types of contaminants, particularly petroleum hydrocarbons (Baumann and others, 2003). Livers of male eastern mosquitofish (Gambusia holbrooki) from Lake Apopka, Fla., a site contaminated with hormonally active compounds, were found to be heavier than those from nearby reference lakes (Toft and others, 2003). Amplified liver mass is presumably due to an increase in liver cell number (hyperplasia) and size (hypertrophy) as a consequence of the induction of the mixedfunction-oxidase system to detoxify (for example, EROD activity) the contaminants (Poels and others, 1980); however, spawning condition can influence liver weight by production of vitellogenin (Myers and Fournie, 2002). Because the liver is the major detoxification organ (Kime, 1998), altered liver morphology or enzymatic activity in fish following exposure to toxicants is common.

The spleen is involved with new blood cell development and immunological interactions. Spleen swelling can indicate a pathobiological response, and hypertrophy of cells is often due to organelle hyperplasia (Arey, 1966). Poor health can lead to bacterial infections in fish, which in turn stimulates the immune system, often resulting in swelling of the spleen. Also, acute tissue damage could result in the protracted production of extracellular matrix, leading to the formation of scar tissue that could enlarge the spleen (Schlenk, 2001). The spleen, kidneys, and liver are filtering organs that are targets for compounds in blood circulation. MAs are accumulations of the macrophage WBC cell type in organs (kidney, liver, and spleen) and have been associated with low dissolved oxygen and organic xenobiotic exposure (Blazer and others, 1997; Fournie and others, 2001). MAs are sites of inflammation, oxygen radical formation, and lipid oxidation (Rice, 2001). Splenic MAs, and to a lesser degree liver and kidney MAs, have been used extensively as indicators of exposure to degraded environments (Blazer and others, 1997; Fournie and others, 2001). Their relative distribution differs among species and also within species in relation to age, environmental stressors, infectious disease, and nutrition (Wolke, 1992; Agius and Roberts, 2003). MAs localize products of tissue destruction, are sites of cellular interactions, and are identifiable histologically. The use of MAs is common for assessing impacts or recovery in aquatic environments; for example, MAs were used in fish health studies and remediation efforts in Burlington Harbor, Vt., on Lake Champlain (Facey and others, 2005).

For the current study, no attempt was made to measure GSI because the collection occurred during different seasons (Zugarramurdi and others, 2003). The GSI may vary naturally with food availability, state of sexual maturation, and life history stage and may not be an accurate indicator of gonadal activity in some species (de Vlaming and others, 1982); however, GSI has been used in conjunction with other indicators for comparing individuals collected within a single season and to show impaired gonadal development that may be due to mercury, leachate, and sewage effluent (Friedmann and others, 1996; Noaksson and others, 2001; Diniz and others, 2005).

When compared with total blood cell numbers, if the WBC percentage is either high or low, immunomodulation may be occurring. Inflammation, parasites, and infectious agents may elevate WBC counts, whereas low numbers of WBCs indicate immunosuppression. Immunomodulation by stressors can be either direct (as in immune response that is due to bacteria) or indirect (as in decreased immune capacity 
due to chronic exposure to stressor via neuroendocrine involvement). Some WBCs are found in organs (such as in MAs), but most are found in the vascular system. Cell trafficking occurs between the organs and the peripheral blood; because contaminants are either absorbed or actively taken up via fish gills, skin, buccal cavity, or gastrointestinal tract (Rice and Arkoosh, 2002), blood cells are directly exposed to the compounds and to reactive metabolites.

Measurement of EROD activity is a well-established biomarker of exposure to particular PAHs and structurally related compounds (Whyte and others, 2000). Many compounds induce EROD activity, a catalytic measurement of cytochrome P4501A, with the most important being analogs of 2,3,7,8-tetrachlorodibenzo-p-dioxin. Responsiveness by EROD results from a wide range of chemicals that share similar structural and toxic properties. The species and the reproductive age of fish, as well as abiotic factors such as water temperature, can influence EROD activity. In the current study, EROD results from fish livers were obtained outside the maximal time (24 months) recommended for liver storage (Anulacion and others, 1997). Because results expressed as relative rates of activity can yield comparable results, the data generated from these tissues stored long-term in liquid nitrogen were suitable for investigating comparisons within and among species collected only in the current study.

Contaminants data from the current study were compared to the levels, ranges, and geometric means from the National Contaminant Biomonitoring Program (NCBP) (Schmitt and Brumbaugh, 1990; Schmitt, Zajicek, and others, 1999). The NCBP data were obtained from composite samples of fish whole bodies from over a hundred stations sampled over multiple years throughout the United States. Inorganic elements included arsenic, cadmium, copper, lead, mercury, selenium, and zinc (Schmitt and Brumbaugh, 1990), and a number of OCs were included (Schmitt, Zajicek, and others, 1999). Table 1 reports the 85 th percentile, trace element ranges, and geometric means. (The 85 th percentile is an arbitrary value used to distinguish NCBP sites having elevated concentrations of the elements.) Additionally, comparisons were made with the BEST 2002 report (Schmitt, 2002), fish tissue data collected from the Caernarvon and Davis Pond sites within the Louisianian Province in the U.S. Enviromental Protection Agency's (EPA) Environmental Monitoring and Assessment Program (EMAP) (Summers, 2001), NOAA's Screening Quick Reference Tables (SQuiRTs) (Buchman, 2003) (see table 2), EPA's national recommended water quality criteria (U.S. Environmental Protection Agency, 1999), the Caernarvon biomonitoring study (Conzelmann and others, 1996), “Contaminant Hazard Reviews 1-35” (Eisler, 1999), the EPA's "Wildlife Exposure Factors Handbook" (U.S. Environmental Protection Agency, 1993), and some texts and scientific literature on specific topics. For historical waterrelated information, an extensive bibliographic report by the USGS National Water-Quality Assessment Program on 39 Louisiana parishes and 5 southwestern Mississippi counties provided citations and abstracts from publication dates 1863 through 2000 (Grimsley and D'Arconte, 2003). Detailed recent ecological information (1999-2000) from about 6.4 $\mathrm{km}$ south of the Davis Pond diversion area was provided in a USGS report (Swarzenski and others, 2004). A searchable database on contaminant exposure and effects is available through the USGS (http://www.pwrc.usgs.gov/contaminantsonline/).

Overall goals of the current study were to report contaminant levels from the five species, to examine nesting success and evidence of food items for eagles, and to consider possible exposure of eagles and their prey to contaminants. The data presented here can be considered a baseline by which to assess possible impacts to the Davis Pond marsh areas postdiversion.

\section{Materials and Methods}

\section{Collection of Fishes}

From January through June 2001, fish were collected (app. 1, table 1-1) according to a final plan dated October 31, 1995 (U.S. Army Engineer District, 1995), and coordinated among agencies including the USGS, USFWS, USACE, and Louisiana Department of Wildlife and Fisheries (LDWF). Fish were collected by LDWF personnel who used electroshock and gill and hoop nets from four sites (figs. 1 and 2): Lake Salvador, Bayou Couba, Lake Cataouatche, and the Mississippi River. Thirty-six fish were harvested, 12 fish from each of three species, with 3 individuals per species per site. Species included largemouth bass, blue catfish, and striped 
Table 2. Range of detectable trace elements ( $\mu \mathrm{g} / \mathrm{g}$, dry weight) in aquatic animal tissues from the Davis Pond prediversion study compared to values listed for freshwater in National Oceanic and Atmospheric Administration (NOAA) Screening Quick Reference Tables (SQuiRTs; Buchman, 2003).

[dw, dry weight. MCL, maximum contaminant levels. CMC, criteria maximum concentration, is the highest concentration of a material in surface water to which an aquatic community can be exposed for a 1-hour average; considered "acute." CCC, criteria continuous concentration, is an estimate of the highest concentration of a material in surface water to which an aquatic community can be exposed for a 4-day average; considered "chronic." Dots indicate "no data"]

\begin{tabular}{|c|c|c|c|c|}
\hline \multirow[t]{2}{*}{ Metals } & \multirow{2}{*}{$\begin{array}{l}\text { Prediversion } 2001 \\
\text { range ( } \mu \mathrm{g} / \mathrm{g} \mathrm{dw})\end{array}$} & \multicolumn{3}{|c|}{ NOAA SQuiRTs 2003 ( $\mu \mathrm{g} / \mathrm{g} \mathrm{dw}$ ) } \\
\hline & & MCL & CMC & CCC \\
\hline Aluminum & $14.67-1,598.87$ & $0.050-0.200$ & . & . \\
\hline Arsenic & $0.48-15.03$ & 0.05 & 0.340 & 0.150 \\
\hline Barium & $1.3-152.43$ & 2.000 & . & . \\
\hline Boron & $1.89-2.21$ & . & . & . \\
\hline Cadmium & $0.1-2.51$ & 0.005 & 0.0043 & 0.00022 \\
\hline Chromium & $1.43-21.46$ & 0.100 & . & . \\
\hline Copper & $0.98-15.97$ & 1.300 & 0.013 & 0.009 \\
\hline Iron & $26.04-2,900$ & 0.300 & . & 1.000 \\
\hline Lead & $0.49-18.3$ & 0.015 & 0.065 & 0.025 \\
\hline Mercury & $0.0772-0.48$ & 0.002 & 0.0014 & 0.00077 \\
\hline Magnesium & $472.72-3,028.62$ & . & . & . \\
\hline Manganese & $3.03-423.64$ & 0.050 & . & . \\
\hline Nickel & $0.49-12.7$ & 0.100 & 0.470 & 0.052 \\
\hline Selenium & $0.49-5.93$ & 0.050 & $0.013-0.186$ & 0.005 \\
\hline Strontium & $10.6-585.08$ & . & . & . \\
\hline Vanadium & $0.51-9.38$ & . & . & . \\
\hline Zinc & $27.63-140$ & 5.000 & 0.120 & 0.120 \\
\hline
\end{tabular}

length comparisons (Carlander, 1969, 1977; Collins, 1985). Because fish were collected from winter through summer, attempts were not made to statistically examine differences in condition factor and GSI among species.

\section{Organosomatic Indices}

Spleens and livers were observed and weighed. Spleens were stored in 10 percent buffered formalin. Livers were cut into 1-cm cubes, placed into cryogenic vials, and immediately stored in liquid nitrogen.

\section{Differential Blood Cell Count}

Whole blood was collected into sodium heparin anticoagulant, and slides were smeared and stained with WrightGiemsa (Sigma-Aldrich, St. Louis, Mo.). For obtaining WBC counts, leukocytes and erythrocytes were identified and enumerated by using bright-field microscopy to total between 300 and 500 cells per slide from at least three fields of view and by using duplicate slides per animal.

\section{Macrophage Aggregates}

Spleens were histologically processed by the Louisiana State University's Department of Pathobiological Sciences,

mullet. Sample collections were performed in accordance with protocols of the USGS BEST Program (Schmitt and others, 1995; Schmitt, Blazer, and others, 1999; Smith and others, 2002) and the National Water-Quality Assessment Program (Crawford and Luoma, 1993).

\section{Biomarkers}

Fish health assessments and collections were performed in accordance with protocols of the USGS BEST Program (Schmitt and others, 1995; Schmitt, Blazer, and others, 1999; Smith and others, 2002). Observations were made on length (in centimeters), weight (in grams), internal and external body appearance, skin, surface, parasite incidence, organ color and condition, spleen and liver weight, gonadal sex and gonad condition, fin condition, and skeletal abnormalities (app. 1, table 1-2). Condition factor was calculated by using the formula weight/length ${ }^{3} \times 10,000$ (Busacker and others, 1990), and age was estimated by performing within-species
School of Veterinary Medicine, Baton Rouge, La. Sections were stained by using a periodic acid Schiff protocol for optimal visualization of MAs. MAs were scored at the USGS National Wetlands Research Center (Lafayette, La.) by using bright-field microscopy at $100 \times$ magnification and were digitally imaged with Image-Pro ${ }^{\circledR}$ Plus, v. 4.5 (Media Cybernetics, Inc., Bethesda, Md.). Three random fields of view were scored for MA frequency (mean number of MA per square millimeter tissue), area (or mean size in square microns), and percent total area occupied per square millimeter of spleen tissue.

\section{EROD Activity}

Microsomal EROD activity was determined by using a revision of a protocol from the USGS Columbia Environmental Research Center. Samples of approximately $0.5 \mathrm{~g}$ were removed from liquid nitrogen and homogenized in $1.5 \mathrm{~mL}$ of cold phosphate buffer. The homogenate was 
centrifuged at $5,452 \times \mathrm{g}(9,000$ relative centrifugal force $)$ in a Hermle Labnet Z323K universal centrifuge (Labnet International, Inc., Woodbridge, N.J.) for 25 minutes at $4{ }^{\circ} \mathrm{C}$, and supernatants were centrifuged in a Beckman Coulter Avanti ${ }^{\circledR} \mathrm{J}-301$ High-Performance Centrifuge at $4^{\circ} \mathrm{C}$ at 100,000 $\times \mathrm{g}(30,000$ revolutions per minute) for 50 minutes. The pellet was retained for assaying EROD activity.

The pellet was resuspended and then distributed with assay chemicals into a clear microplate by using a microplate reader (GENios, Tecan Instruments, Mannedorf, Switzerland) with the excitation filter at 530 nanometers $(\mathrm{nm})$, the mission filter at $580 \mathrm{~nm}$, and the gain at 55. Fluorescamine (Sigma) was added to the wells for protein determination with the excitation filter at $360 \mathrm{~nm}$, the emission filter at $460 \mathrm{~nm}$, and the gain at 55. The assay is based on the ability of the CYP1A protein to convert a substrate (7-ethoxyresorufin) (Sigma) to a fluorescent product (resorufin). Resorufin and protein standards (bovine serum albumin) were measured and expressed as picomoles per minute per milligram protein. Over the previous 3-plus years, the optimization and validation of the laboratory assay for EROD levels occurred; therefore, results are comparable for only the current study.

\section{Collection of Bivalves}

Freshwater Atlantic rangia clams were collected from Bayou Couba and Lake Salvador on January 9, 2001, and from Lake Cataouatche on May 8, 2001, by using a boattowed dredge. Zebra mussels were collected from the bank of the Mississippi River in February 2003 by using a longhandled net. These bivalves were opened with a stainless steel oyster knife that had been cleaned by rinsing in tap water, denatured alcohol, and then in distilled water. Composite samples weighing at least $50 \mathrm{~g}$ (about 30 Atlantic rangia clams and hundreds of immature zebra mussels) were frozen at $-20^{\circ} \mathrm{C}$ until shipment on dry ice to the appropriate facility for contaminants analyses.

\section{Collection of Eaglet Blood}

Information on nest locations and on the approximate ages of nestlings within the proposed sampling region was obtained from LDWF. Blood samples were collected from two nests in the Davis Pond area and from three nests in a reference area near Houma, La., during the first 2 weeks of February 2001. Eaglets were banded (app. 1, table 1-3). The nests failed in 2000, so eaglets from clutches in 2001 were sampled. Below normal temperatures and drought conditions occurred that year. Historical activity of the sampled bald eagle nests was obtained from LDWF (app. 1, table 1-4).

Personnel from a professional tree-climbing service accessed the nests and lowered the eaglets to the ground for banding and blood collection. Debris and food items in nests and condition of eaglets were noted. Blood samples were collected from brachial leg veins of the eaglets (which were approximately 8 weeks old) by using sodium heparinized 1-mL disposable syringes with 22-gage needles. Eaglets were then returned to nests. Whole blood was transported to the lab in glass tubes on ice and then frozen in cryogenic vials at $-80^{\circ} \mathrm{C}$ until shipment on dry ice to the appropriate facility for contaminant analyses.

\section{Analyses for Contaminants}

Fish whole bodies, bivalve composites, and eagle whole blood samples were sent to USFWS Analytical Control Facility (Laurel, Md.) for handling and for data quality control checks. Fish were wrapped in heavy-duty food-grade aluminum foil (no. 2411, Alcan Foil Products, La Grange, Ga.) that conforms to U.S. Food and Drug Administration regulation 178.3910 (with chemical composition of the wrought aluminum alloy as aluminum at 99.00 percent according to the Material Safety Data Sheet), frozen at $-20^{\circ} \mathrm{C}$, and sent on dry ice. Consistent with the NCBP, major contaminant screens were conducted for contaminant groups. The biomonitoring plan (U.S. Army Engineer District, 1995) specified analyses of EPA priority pollutants for which approved tissue analysis methods exist. The inorganic compound analyses were performed by the Geochemical and Environmental Research Group, Texas A\&M (College Station, Tex.), and the organic compound scans were performed by Mississippi State Chemical Lab (MSCL; Mississippi State, Miss.). Aquatic animal tissues received the major screens (metals, AHs, PAHs, and OCs), and eaglet blood received the $\mathrm{OC}$ and metal scans. Resultant data were reviewed and evaluated for accuracy as part of a quality-control/ quality-assurance program at the Analytical Control Facility. Individual laboratories performed standard quality-control and quality-assurance checks and used duplicate samples, spiked samples, standard reference materials, and procedural blanks. The limits of detection were defined as the Student's t test value for 99 percent confidence multiplied by the standard deviation of seven replicate measurements of the same lowlevel sample (Code of Federal Regulations, 2006).

Analyses for AHs and PAHs were done by first digesting tissue with potassium hydroxide, then neutralizing, and then reconstituting in petroleum ether before transfer to a silica gel chromatography column. Eluates of $\mathrm{AH}$ and $\mathrm{PAH}$ residues were separated by eluting aliphatics from the column with petroleum ether followed by elution of aromatics with methylene chloride with petroleum ether mixture and then methylene chloride. This eluate was concentrated for quantification by capillary column, flame ionization gas chromatography (MSCL standard operating procedure [SOP] 1.265). The aromatic hydrocarbon fraction was reconstituted in methylene chloride and quantified by gas chromatographymass spectroscopy (MSCL SOP 1.276).

Separation of OC pesticides and PCBs was done on a 
silicic acid chromatographic column following analysis by megabore column electron capture gas chromatography (MSCL SOP 1.267). Total PCBs were calculated by adding the sum of Aroclors 1242, 1248, 1254, and 1260.

Analysis for metals followed procedures contained in SOPs of the Geochemical and Environmental Research Group (tissue digestion SOPs 0006 and 9408 and analysis SOPs 9409 and 9802). For trace metals analyses, frozen samples were thawed, subsamples removed for percent dry weight and trace metals analyses, and subsamples were freeze dried. Tissues were macerated by using a Teflon ${ }^{\circledR}\left(\right.$ Dupont $\left.^{\mathrm{TM}}\right)$ spatula, and the freeze-dried subsamples were ground to a fine powder, weighed to $0.1 \mathrm{mg}$, and transferred into a 50$\mathrm{mL}$ polypropylene centrifuge tube. Concentrated sulfuric acid $(2.5 \mathrm{~mL})$ was added and vortexed, and then concentrated nitric acid $(1.5 \mathrm{~mL})$ was added and vortexed. The sample tube was capped loosely and then heated in a water bath at $90^{\circ} \mathrm{C}-95^{\circ} \mathrm{C}$ for 30 minutes. After cooling, distilled deionized water $(10 \mathrm{~mL})$ was added and vortexed, and then 5 percent (by weight) potassium permanganate $(10 \mathrm{~mL})$ and 5 percent (by weight) potassium persulfate $(5 \mathrm{~mL})$ were added to each tube. The tube was vortexed, capped tightly, and left overnight at room temperature (more than 12 hours). A sodium chloride/ hydroxylamine sulfate solution $(5 \mathrm{~mL})$ was added to reduce excess permanganate, and the digestate was brought to a final volume of $35 \mathrm{~mL}$ with deionized water prior to analysis. The tube was mixed until the manganese oxide particles were dissolved, and then samples were analyzed by using cold vapor atomic absorption spectrophotometry (Geochemical and Environmental Research Group SOP 006).

\section{Statistical Analyses}

To investigate possible differences in selected biomarkers among sites and among species, the SAS ${ }^{\circledR}$ (Cary, N.C.) GLM multivariate analysis of variance, with a fixed effects model after tests of homogeneity, was performed with alpha value at 0.05 . Analyses were also run per species, for which appropriate transformations were used: percent WBC as arcsine (sqrt[pWBC/100]), HSI as arcsine (sqrt[HSI/100]), SSI as arcsine (sqrt[SSI/100]), MA area log or sqrt, and MA frequency as log. Organosomatic indices are usually performed as a weight to length ratio, but ratios do not conform to common statistical distributions (Adams, 2002). Statistical analysis of the condition factor (app. 1, fig. 1-1) was not performed because fish were collected during three seasons. The HSI is presented (app. 1, fig. 1-2). Tests for correlations with age, weight, and length were tested with each variable. The hypothesis was that no significant difference existed between sites, between species, or in the interaction between site and species for biomarkers. Two-way and oneway analyses of variance tests were employed, where alpha is $0.05 / 26=0.001923$ for pairwise comparisons. Power analysis for indicating appropriate sample sizes needed for biomarker analyses was performed.

\section{Results}

No gross abnormalities in skeletal, skin, or internal conditions were noted in fish collected (see app. 1, table 1-2). Each fish showed red to dark red coloration of livers, and this characteristic is considered to be indicative of a healthy spleen (Schmitt, 2002). Blue catfish were generally heavier than the other species, and weights were significantly different among species $(P=0.0409)$ (app. 1, fig. 1-3).

No significant differences in SSI (fig. 3) were noted among species, among sites, or with species and site interactions.

No significant differences in percent WBCs (figs. 4 and 5) were noted among species or sites or with species and site interactions; however, largemouth bass displayed significantly lower WBCs with increasing total AHs than did the other two fish species $(P=0.0003)$. There was a significant site effect in that WBCs in largemouth bass were higher at the Mississippi

River than at Lake Salvador $(P=0.0244)$ (fig. 5). The percent of WBCs for largemouth bass at the Lake Salvador site was lower, although not significantly, than the percentages at all of the other sites for each species.

MAs stained darker than the surrounding spleen tissue (fig. 6). When GLM analysis of variance was used, results indicated that the total area of MA and the frequency (fig. 7) were significantly different among species. Values were higher in mullet than in the other two species for MA area and frequency $(P=0.0055$ and $P=0.0014$, respectively). For both MA biomarkers, there were some significant species and site interactions.

Tests of all biomarkers per species with age, weight, and length indicated no correlations. Analysis of results for statistical power indicated that a sample size of 20 fish per species per site would add more confidence in results for future statistical analyses.

Data on EROD were collected beyond the optimum time for analyses for frozen storage; therefore, EROD data (fig. 8) are comparable within the current study but not between the current study and the planned postdiversion studies. Low sample sizes rendered categorical (for example, low, medium, and high enzyme activity) analyses inapplicable. In nonparametric analyses, largemouth bass enzyme levels were significantly higher at the Mississippi River site than at Lake Cataouatche and Bayou Couba $(P=0.0390)$.

\section{Graphics for Contaminants Analyses}

The graphs that follow present the data grouped per site locations north to south, and the species order per group, left to right, is largemouth bass, blue catfish, striped mullet, and bivalves (striped bars). Results are presented as parts per million ( $\mathrm{ppm}), \mu \mathrm{g} / \mathrm{g}$ wet weight (ww) or fresh weight (fw) for organics, and $\mu \mathrm{g} / \mathrm{g}$ dry weight (dw) for trace and major elements (dry weight can be converted to wet weight 


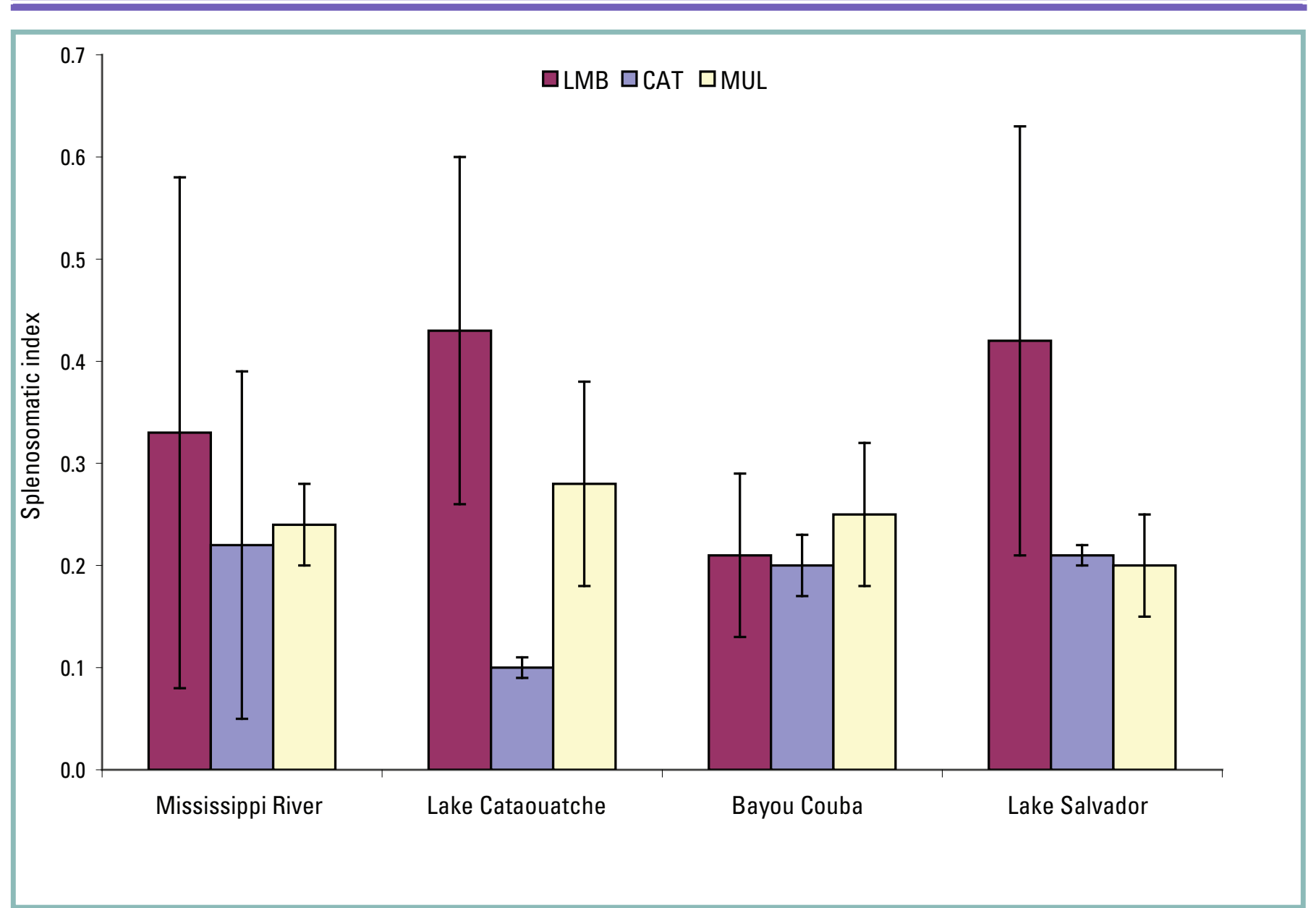

Figure 3. Splenosomatic indices (SSl; spleen weight/body weight $\times 100$ ) ( \pm standard error) from largemouth bass (LMB), blue catfish (CAT), and striped mullet (MUL) collected at four sites in southern Louisiana for the Davis Pond prediversion biomonitoring study in 2001.

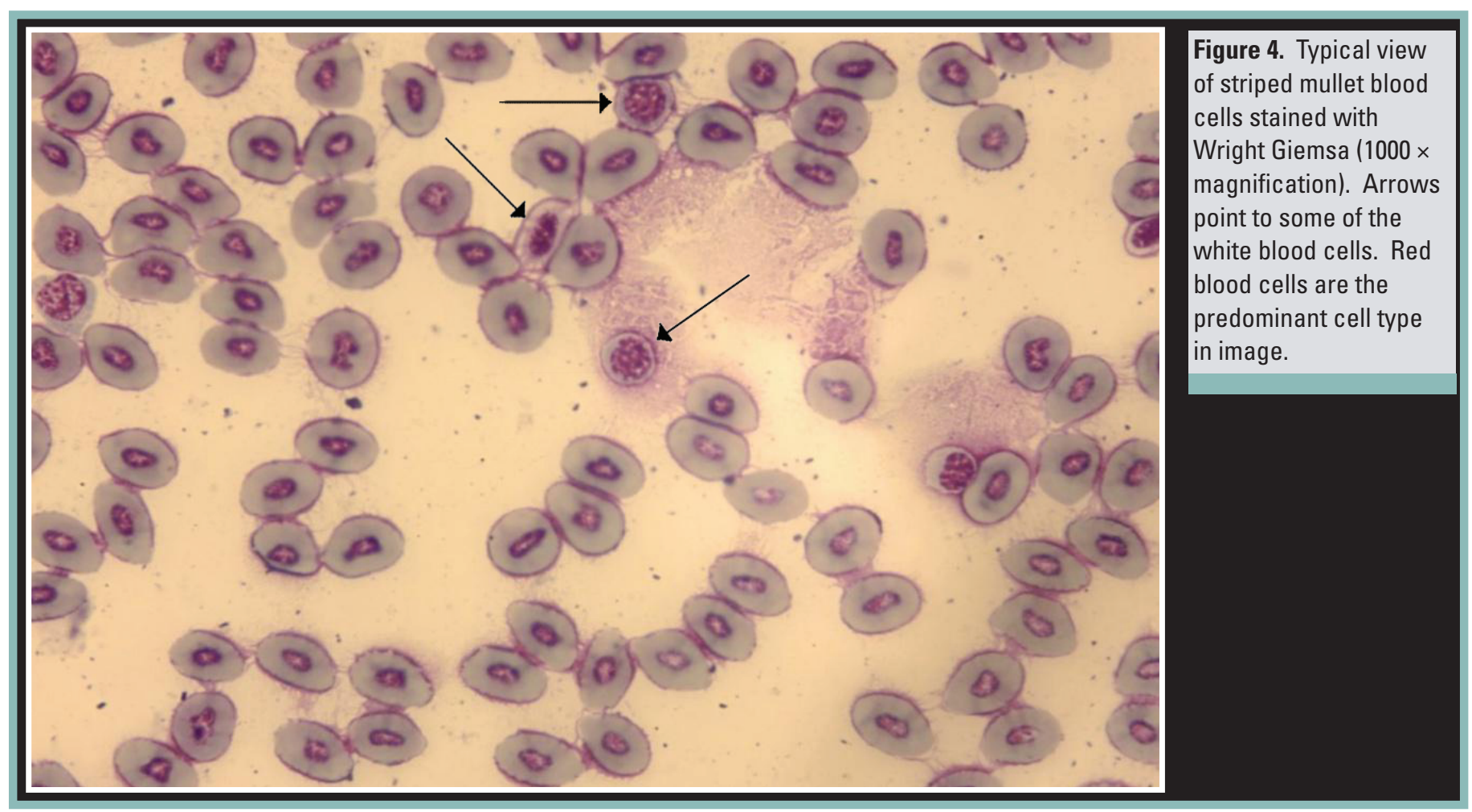




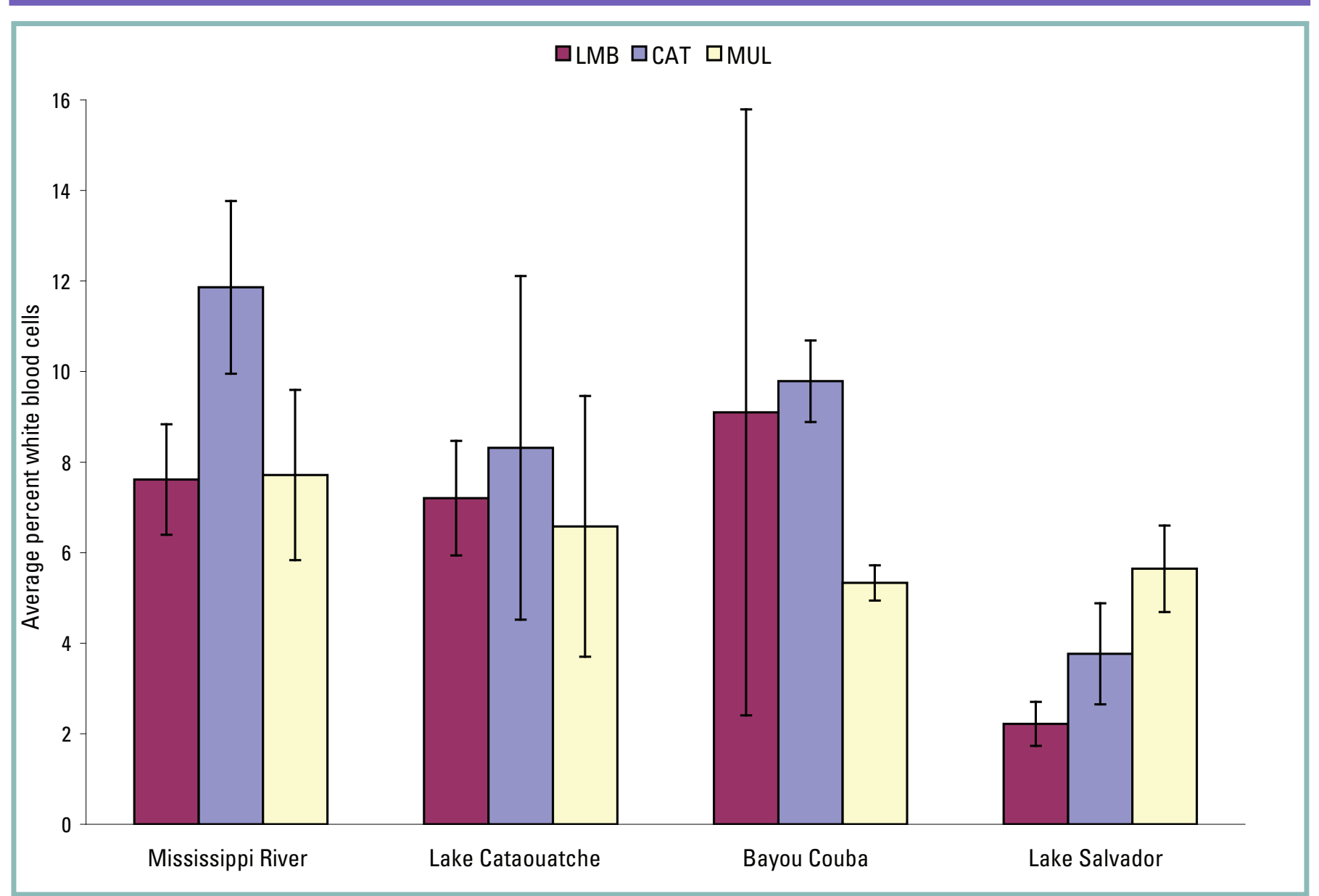

Figure 5. Average percent white blood cells per total cells ( \pm standard error) per species of fish. Largemouth bass (LMB), blue catfish (CAT), and striped mullet (MUL) were collected at sites in southeastern Louisiana in 2001 ( $n=3$ per bar except for $n=2$ largemouth bass at Bayou Couba).

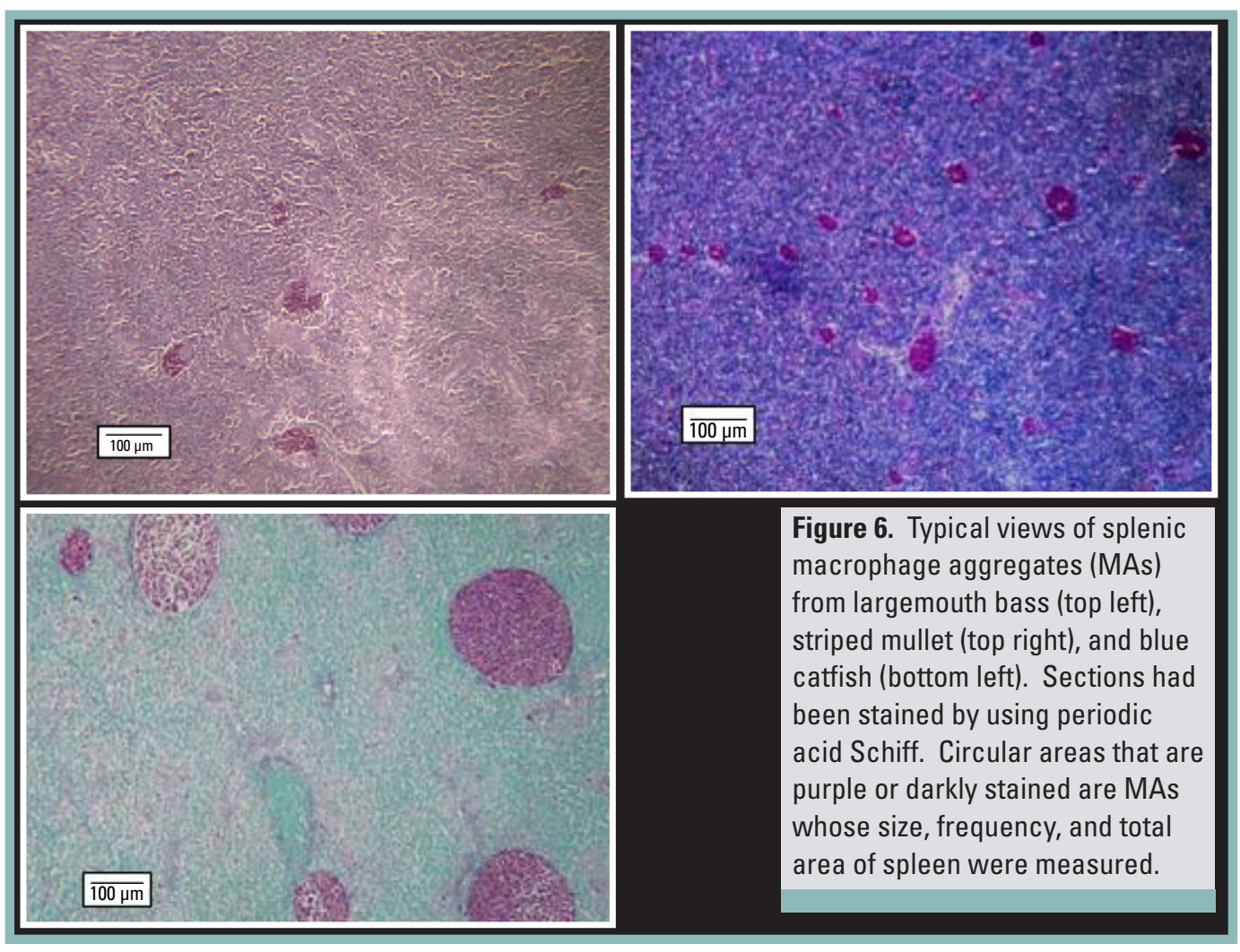




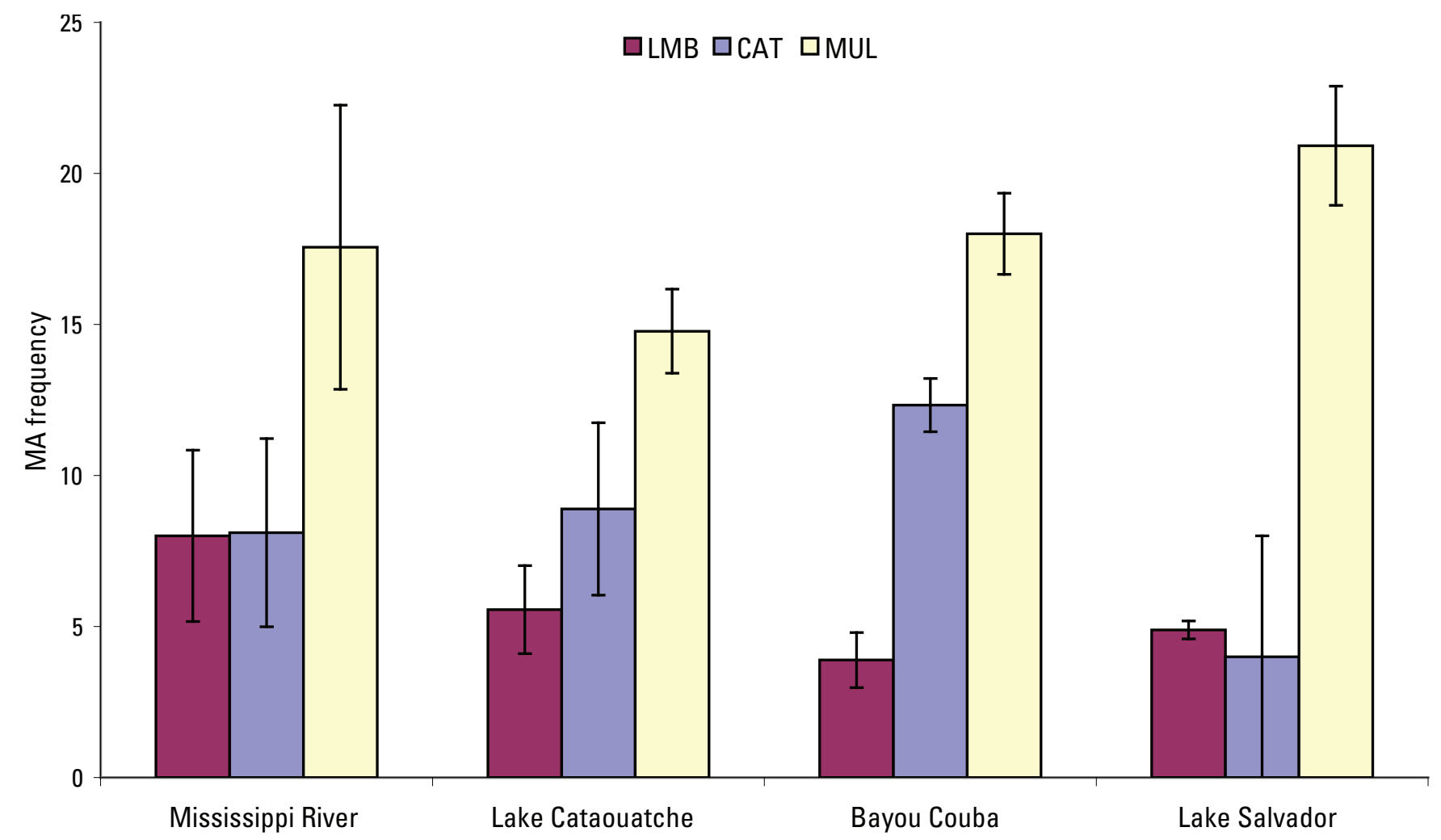

Figure 7. Frequency of macrophage aggregates (MAs) ( \pm standard error) per spleen of largemouth bass (LMB), blue catfish (CAT), and striped mullet (MUL) collected at sites in southeastern Louisiana in 2001.

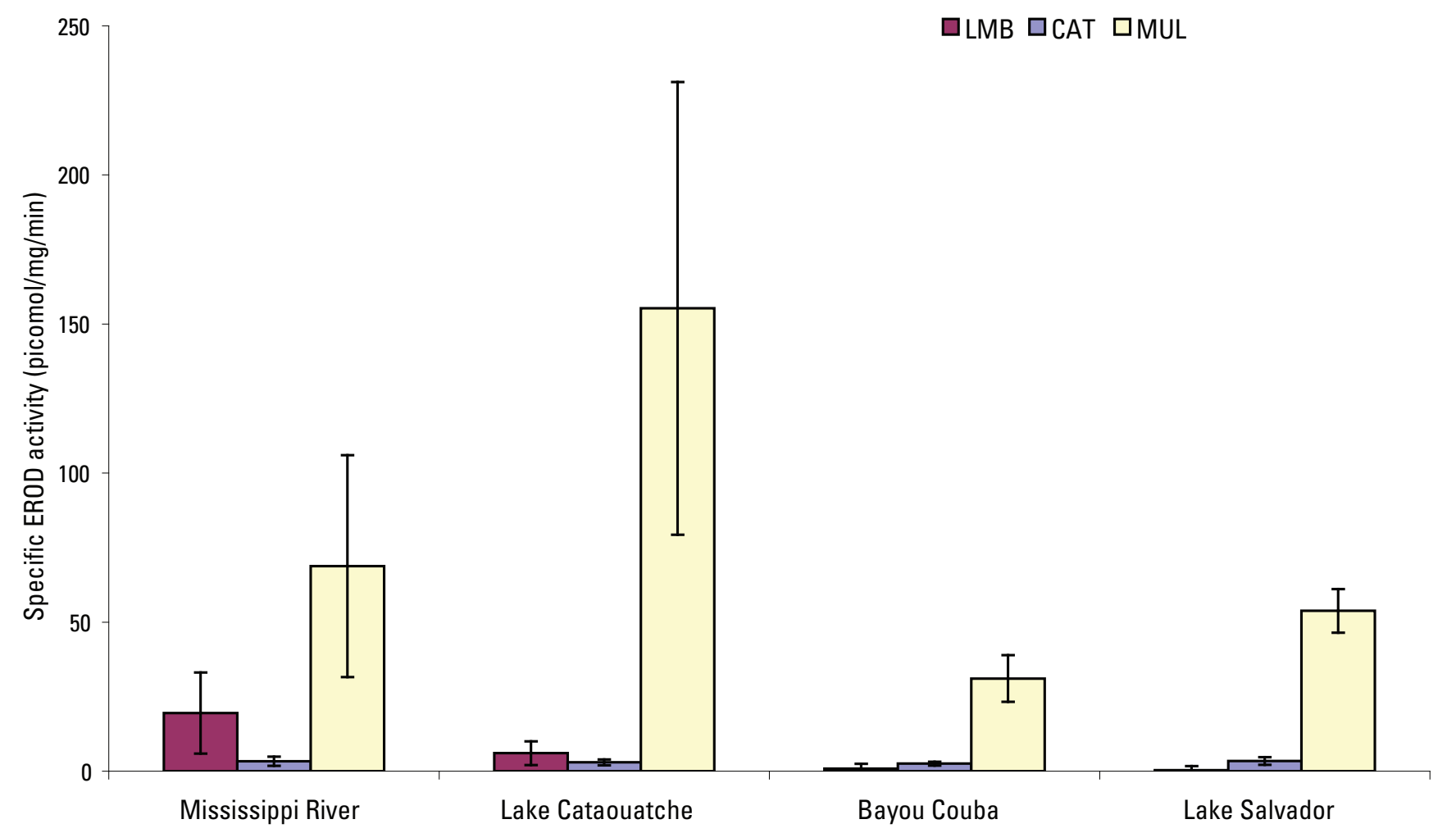

Figure 8. Average ethoxyresorufin-o-deethylase (EROD) specific activity ( \pm standard error) in largemouth bass (LMB), blue catfish (CAT), and striped mullet (MUL) collected at sites in southeastern Louisiana in 2001. 
assuming 71 percent moisture and using a conversion factor of 0.29). Levels below detection limits (BDL) reported are for aquatic samples other than bivalves from the river, which were obtained and analyzed after the other samples.

In the current study, in each sample in which "total OC" was reported (fig. 9), DDE and total PCBs were detected in all but one animal. In the current study, $p, p$ '-DDE and total PCBs were the most frequently detected OC, and they were primarily from the Mississippi River site (table 3). The OCs were detectable in 67 percent of the fish from the Mississippi River site, ranging from 0.15 to $1.09 \mu \mathrm{g} / \mathrm{g}$. From the other sites, 11 percent of the fish contained detectable levels of OCs. Only mussels from the Mississippi River had detectable levels of OCs. The levels of total OCs in mullet from Mississippi River and Bayou Couba were significantly higher $(P<0.00167)$ than levels in mullet from Lake Cataouatche and Lake Salvador. Total OCs in catfish were higher at Lake Salvador than at Lake Cataouatche and Bayou Couba $(P<$ 0.00167). Eaglet blood data yielded few detectable specific OCs (such as $p, p$ '-DDE and oxychlordane) (table 4).

In the current study, two catfish from marsh sites and two largemouth bass from the Mississippi River exhibited $p, p$ '-DDE at low levels (0.011-0.041 $\mu \mathrm{g} / \mathrm{g} \mathrm{ww})$, and one largemouth bass from the Mississippi River contained $0.15 \mu \mathrm{g} / \mathrm{g}$ ww, which does not exceed the geometric mean for NCBP (see table 5) or approach the maximum level detected in the 1995 study (8.30 $\mu \mathrm{g} / \mathrm{g} \mathrm{ww}$ ) (Schmitt, 2002). The $0.15 \mu \mathrm{g} / \mathrm{g}$ fw in a Mississippi River largemouth bass (LMB35RIVER) does, however, exceed the geometric means from bass $(0.04 \mu \mathrm{g} / \mathrm{g} \mathrm{ww})$ from the Mississippi Embayment (Schmitt, 2002).

The greatest occurrence, frequency, and concentrations of OCs found in the Caernarvon area were those of chlordane, PCBs, and DDT metabolites, and as with the current study, OCs were mainly found in the Mississippi River fishes (Conzelmann and others, 1996). No Caernarvon biota exceeded any of the NCBP OC concentrations (see table 5). In 2000, in a study at the Barataria Bay basin, fish (bowfin [Amia calva], bluegill [Lepomis macrochirus], largemouth bass, and common carp [Cyprinus carpio]) sampled about 6.4 $\mathrm{km}$ south of the Davis Pond diversion area were found to have no detectable levels of OC pesticides or PCBs (Swarzenski and others, 2004). In the 1995 BEST study (Schmitt, 2002), $p, p$ '-DDE was detected in 91 percent of the samples and at all stations, with the greatest DDT concentrations $(>0.01 \mu \mathrm{g} / \mathrm{g})$ occurring in the Mississippi River basin.

In the Mississippi River Toxics Inventory Project (MRTIP, a 3-year study of fish and shellfish tissues conducted by the Louisiana Department of Environmental Quality), fish fillet and invertebrate composite samples were collected from six sites along the Mississippi River from the Arkansas State line to Venice, La., and from adjacent flood plains between 1990 and 1994, and tissues were analyzed for priority pollutants (Henrich and others, 1995). One composite sample contained the insecticide dieldrin above the then current 0.30-ppm Food and Drug Administration (FDA) fish consumption alert level (intended to protect humans from the chronic effects of toxic substances consumed in foodstuffs). In the current study, two Mississippi River catfish contained dieldrin at levels of 0.015 and $0.077 \mu \mathrm{g} / \mathrm{g} \mathrm{ww}$ (ppm), which are below the current FDA action level of $0.100 \mathrm{ppm}$. The two catfish that showed levels of dieldrin in the Caernarvon study were also from the Mississippi River; the levels were 0.08 and $0.04 \mu \mathrm{g} / \mathrm{g}$ ww (Conzelmann and others, 1996). Aldrin, an insecticide with a chemical structure similar to that of dieldrin, breaks down to dieldrin in the body. Aldrin is on the National Priorities List of the EPA, and both have been banned for use since 1987. No toxaphene, a chlorinated camphene, was detected in any of the samples in the current study or in the Caernarvon study (Conzelmann and others, 1996). In the MRTIP, 7 percent of the composite samples had detectable toxaphene levels (Henrich and others, 1995).

In the current study, the range of total PCBs was from 0.057 to $0.79 \mathrm{ppm}$, with one value (from sample LMB35RIVER) exceeding the NCBP geometric mean (0.39 ppm). The Caernarvon total PCB values were comparable to averages from the first year of sampling in the MRTIP (Henrich and others, 1995), where the values ranged up to $0.038 \mu \mathrm{g} / \mathrm{g}$. The range of mean PCB concentrations in the composite fillets in the MRTIP study was $0.001-0.188 \mathrm{ppm}$. In the Caernarvon prediversion and postdiversion samplings (Conzelmann and others, 1996), 9 percent and 24 percent, respectively, of the fish exhibited total PCB levels that exceeded the NCBP geometric mean. In the current study, no PCBs were detected in eaglet blood (table 4). Previous studies of levels of PCBs in Louisiana's watersheds (Dowd and others, 1985; Schmitt and others, 1990) have pointed toward the importance of monitoring PCBs in Louisiana's drainages.

In a study of eagles across the Great Lakes region (Bowerman and others, 2003), measures of $p, p^{\prime}$-DDE and total PCBs in nestling blood were reflective of adult reproductive success on a regional scale. The lessening of the eggshellthinning effects because of lowered levels of $p, p$ '-DDE has been a major reason for the resurgence of bald eagle populations (Colborn, 1991); however, recovery has not been uniform, and maintaining relatively uncontaminanted food sources for eagles during the breeding season has been recommended (Bowerman and others, 2003). In 1993, the trans-nonachlor concentration was at $2.19 \mu \mathrm{g} / \mathrm{g}$ in an egg from a bald eagle from Tangipahoa Parish in Louisiana, a concentration that exceeds the geometric mean by a factor of 2.7 (Conzelmann and Rabot, 1994). In this sample, total PCBs mirrored the geometric mean (Conzelmann and Rabot, 1994).

In the current study, no mirex was detected in the aquatic animal samples or in eaglet blood. A degradation product of mirex is hexachlorobenzene (HCB). In the current study, only one fish sample (CAT39RIVER) showed levels of $\mathrm{HCB}$, which was similar to the number of occurrences in the Caernarvon study (Conzelmann and others, 1996), in which only a few fish from the Mississippi River showed levels of HCB. In the MRTIP, over 84 percent of samples showed isomers of benzene hexachloride (BHC; also known 


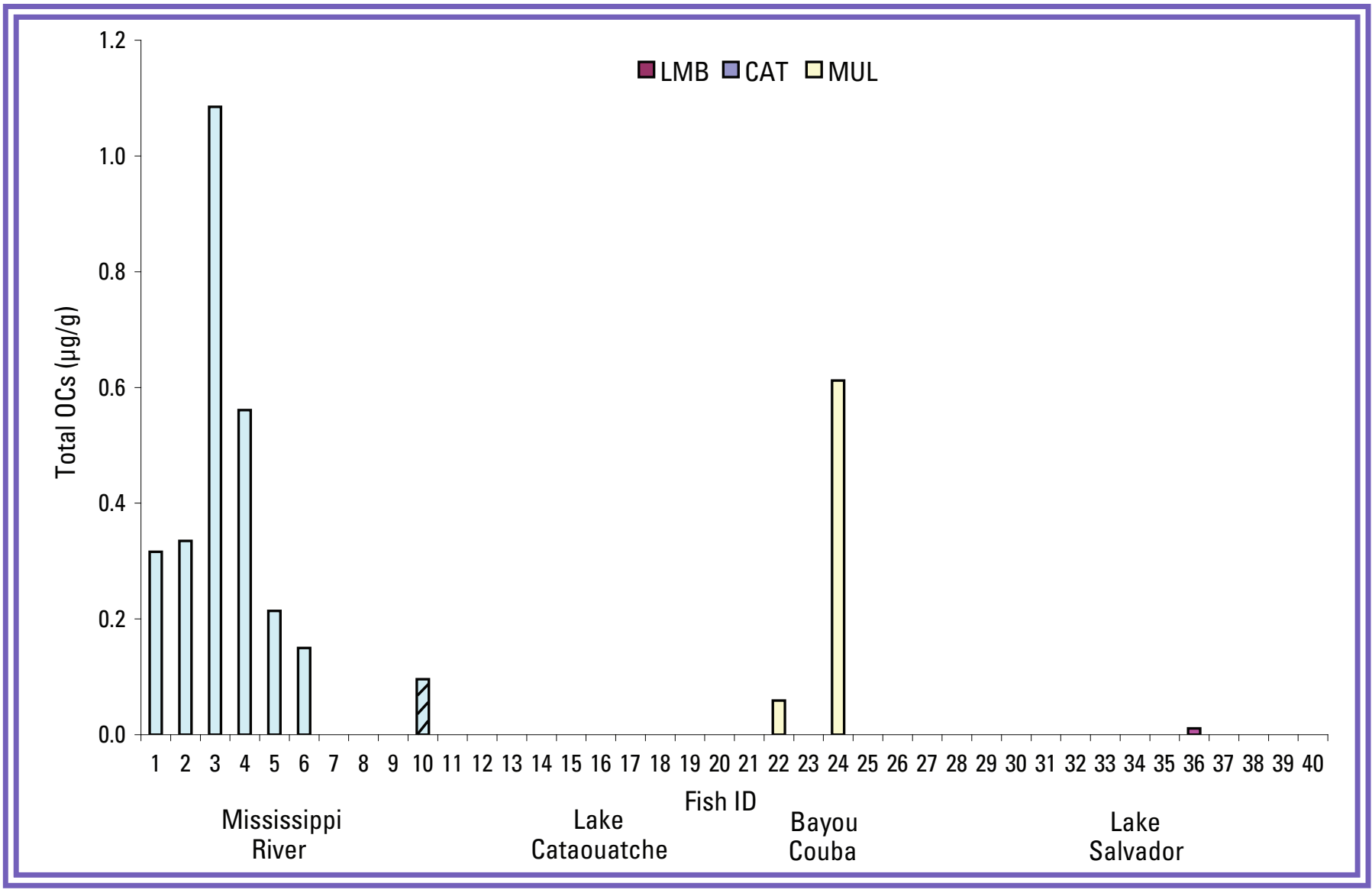

Figure 9. Total

organochlorines (OCs, in wet weight) from largemouth bass (LMB), blue catfish (CAT), and striped mullet (MUL) collected from sites in southeastern Louisiana from January through June 2001. The lower limit of detection was 0.010 parts per million. Striped bars represent values for bivalves. $B D L$, below detection limits. Quality control of data checked by the U.S. Fish and Wildlife Service Analytical Control Facility.

\begin{tabular}{clcclc}
\hline Fish ID & Sample ID & Total OCs & Fish ID & Sample ID & Total OCs \\
\hline 1 & LMB33RIVER & 0.316 & 21 & LMB10COUBA & BDL \\
2 & LMB34RIVER & 0.335 & 22 & LMB11COUBA & 0.059 \\
3 & LMB35RIVER & 1.085 & 23 & LMB3COUBA & BDL \\
4 & CAT38RIVER & 0.561 & 24 & CAT12COUBA & 0.612 \\
5 & CAT36RIVER & 0.214 & 25 & CAT13COUBA & BDL \\
6 & CAT37RIVER & 0.15 & 26 & CAT14COUBA & BDL \\
7 & MUL30RIVER & BDL & 27 & MUL26COUBA & BDL \\
8 & MUL31RIVER & BDL & 28 & MUL27COUBA & BDL \\
9 & MUL32RIVER & BDL & 29 & MUL28COUBA & BDL \\
10 & MUSSRIVER & 0.096 & 30 & MUSSCOUBA & BDL \\
11 & LMB21CATA & BDL & 31 & LMB4CAMP & BDL \\
12 & LMB24CATA & BDL & 32 & LMB5CAMP & BDL \\
13 & LMB25CATA & BDL & 33 & LMB6CAMP & BDL \\
14 & CAT22CATA & BDL & 34 & CAT1CAMP & BDL \\
15 & CAT23CATA & BDL & 35 & CAT2CAMP & BDL \\
16 & CAT7CATA & BDL & 36 & CAT3CAMP & 0.011 \\
17 & MUL18CATA & BDL & 37 & MUL15CAMP & BDL \\
18 & MUL19CATA & BDL & 38 & MUL16CAMP & BDL \\
19 & MUL20CATA & BDL & 39 & MUL17CAMP & BDL \\
20 & MUSSCATA & BDL & 40 & MUSSCAMP & BDL \\
\hline
\end{tabular}




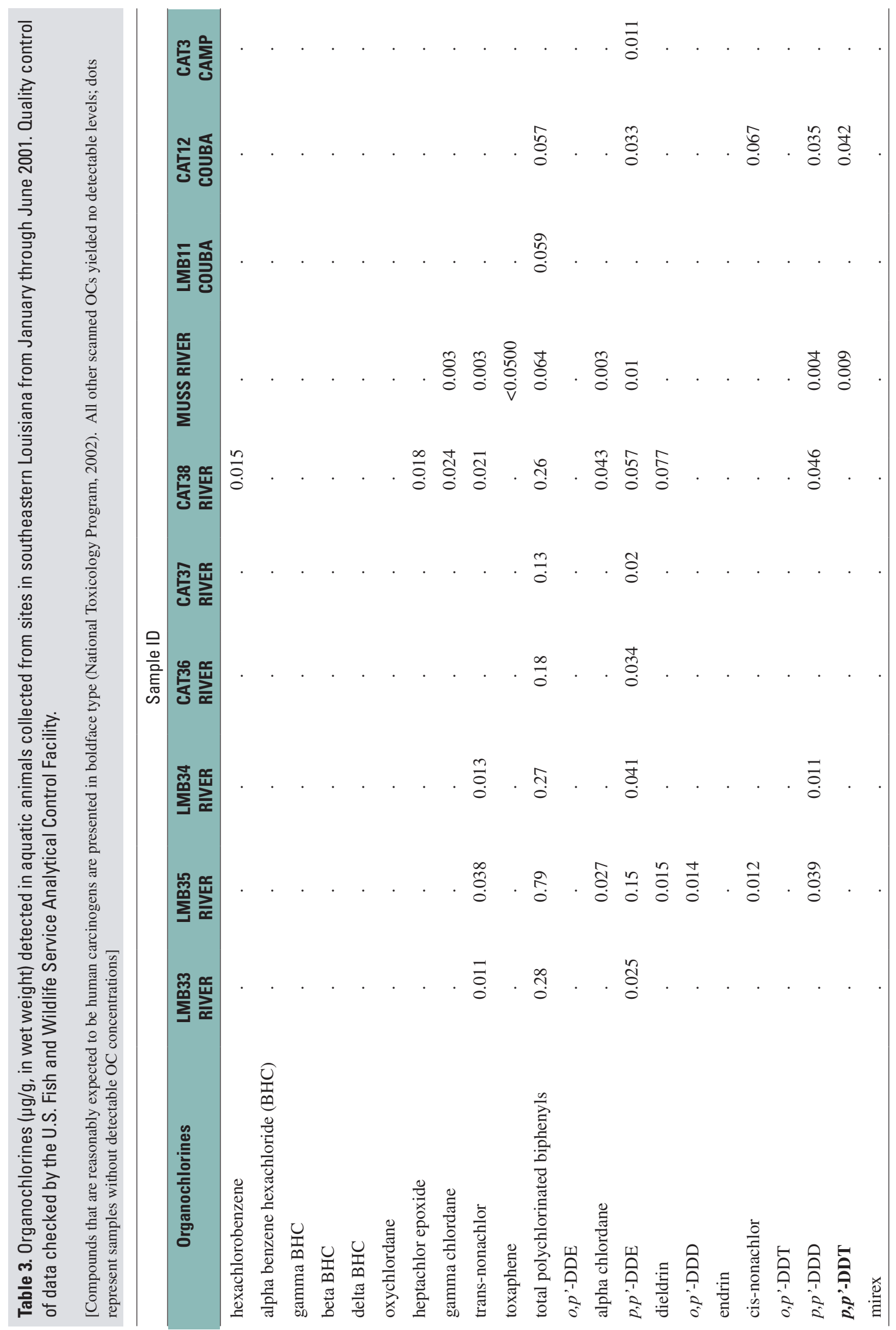


Table 4. Levels of organochlorines in eaglet whole blood. Quality control of data checked by the U.S. Fish and Wildlife Service Analytical Control Facility.

[Measurements are in $\mu \mathrm{g} / \mathrm{g}$, wet weight. Dots indicate a result that was less than the detection limit; detectable levels were lower than those indicated in toxic effects on eagles (U.S. Geological Survey, 2007b)]

\begin{tabular}{|c|c|c|c|c|c|c|}
\hline \multicolumn{7}{|c|}{ Eaglet sample ID } \\
\hline Analyte & H159 & H160 & H169 & S156 & S157 & S158 \\
\hline hexachlorobenzene & . & & . & . & . & . \\
\hline alpha benzene hexachloride (BHC) & . & & . & . & . & . \\
\hline gamma BHC & . & . & . & . & . & . \\
\hline beta BHC & . & . & . & . & . & . \\
\hline delta BHC & . & . & . & . & . & . \\
\hline oxychlordane & . & . & . & . & 0.0020 & . \\
\hline heptachlor epoxide & . & & . & . & . & . \\
\hline gamma chlordane & . & & . & . & . & . \\
\hline trans-nonachlor & . & . & . & . & . & . \\
\hline toxaphene & . & . & . & . & . & . \\
\hline total polychlorinated biphenyls & . & . & . & . & . & . \\
\hline$o, p^{\prime}-\mathrm{DDE}$ & . & . & . & . & . & . \\
\hline alpha chlordane & . & . & . & . & . & . \\
\hline$p, p^{\prime}-\mathrm{DDE}$ & . & . & 0.0050 & . & 0.0020 & 0.0060 \\
\hline dieldrin & & . & . & . & & \\
\hline$o, p^{\prime}-\mathrm{DDD}$ & . & . & . & . & & . \\
\hline endrin & . & . & . & . & . & . \\
\hline cis-nonachlor & . & . & . & . & . & . \\
\hline$o, p^{\prime}-\mathrm{DDT}$ & . & . & . & . & . & . \\
\hline$p, p^{\prime}-\mathrm{DDD}$ & . & . & . & . & . & . \\
\hline$p, p^{\prime}-\mathrm{DDT}$ & . & . & . & . & & . \\
\hline mirex & . & . & . & . & & \\
\hline
\end{tabular}


Table 5. Ranges and geometric means of organochlorines (in $\mu \mathrm{g} / \mathrm{g}$, wet weight) from the National Contaminant Biomonitoring Program (Schmitt, 1990).

[BDL, below detection limit. DDE, dichlorodiphenyldichloroethylene; DDT, dichlorodiphenyltrichloroethane; DDD, dichlorodiphenyldichloroethane]

\begin{tabular}{lcc}
\hline \multicolumn{1}{c}{ Parameter } & Range & Geometric mean \\
\hline hexachlorobenzene & BDL-0.41 & $<0.01$ \\
alpha benzene hexachloride & BDL-0.04 & 0.01 \\
gamma benzene hexachloride & BDL-0.01 & $<0.01$ \\
oxychlordane & BDL-0.29 & 0.01 \\
heptachlor epoxide & BDL-0.29 & 0.01 \\
trans-nonachlor & BDL-1.00 & 0.03 \\
toxaphene & BDL-8.20 & 0.14 \\
alpha chlordane & BDL-0.66 & 0.03 \\
gamma chlordane & BDL-0.35 & 0.02 \\
dieldrin & BDL-1.39 & 0.04 \\
endrin & BDL-0.22 & $<0.01$ \\
cis-nonachlor & BDL-0.45 & 0.02 \\
$p, p '-D D E$ & BDL-4.74 & 0.19 \\
$p, p '-D D D$ & BDL-2.55 & 0.06 \\
$p, p$ '-DDT & BDL-1.79 & 0.03 \\
total DDT & BDL-9.08 & 0.26 \\
mirex & BDL-0.44 & $<0.01$ \\
total polychlorinated biphenyls & BDL-6.70 & 0.39 \\
\hline
\end{tabular}

as hexachlorocyclohexane [of which lindane is a gamma isomer]). In that study, BHC was the compound that was found to have the highest risk component on the basis of frequency of occurrence and risk-assessment levels.

If the range of PAHs in the sediments were to correspond to $0.1-1 \mathrm{ppm} \mathrm{dw}$ (or $0.03-0.3 \mathrm{ppm} w \mathrm{w}$ ), then this would translate to biological effects in vertebrates and invertebrates (Beyer and others, 1996). In the current study, PAHs were detected in each sample (fig. 10), but no trends in accumulation were noted. The range detected in fish was $0.03-1.60 \mu \mathrm{g} / \mathrm{g} w \mathrm{w}$, and the highest level (17.534 $\mu \mathrm{g} / \mathrm{g} \mathrm{ww})$ was seen in the bivalve composite from the Mississippi River; the concentration of PAHs in bivalves reflects that in the environment (Beyer and others, 1996).

The levels of PAHs in tissues were not investigated in the MRTIP (Henrich and others, 1995), the Barataria Preserve investigation (Swarzenski and others, 2004), or the prediversion portion of the Caernarvon study (Conzelmann and others, 1996). In the Caernarvon study, in comparison with the first postdiversion sampling, the second postdiversion sampling showed an increase in occurrence and concentration in both Mississippi River and marsh biota (Conzelmann and others, 1996), with ranges of total PAHs in Mississippi River fishes from 0.03 to $1.73 \mu \mathrm{g} / \mathrm{g}$ ww and at marsh sites from 0.01 to $0.26 \mu \mathrm{g} / \mathrm{g}$ ww.

Of the PAHs (app. 1, table 1-5), benzo(a)pyrene (BaP) has received much attention in terms of immunotoxicity (Rice and Arkoosh, 2002). This compound is mutagenic, carcinogenic, and immunotoxic because of metabolic activation by hepatic xenobiotic metabolizing enzymes such as CYP1A. In fish, dimethylbenzanthracene and $\mathrm{BaP}$ are potent immunotoxic and carcinogenic agents. In the current study, the single PAH detectable in every fish was $\mathrm{BaP}$, with a range of 0.014-0.53 $\mu \mathrm{g} / \mathrm{g}$, with four fish over $0.10 \mu \mathrm{g} / \mathrm{g}$ (app. 1, table 1-6). BaP was not detectable in bivalves. One fish (MUL31RIVER, fish ID 8) showed about 53 percent of the detectable PAHs of Mississippi River fish samples. The average percent WBCs for mullet from all sites was 6.3 percent with a standard error (SE) of 0.78; MUL31RIVER displayed the highest percentage of all mullet from all sites (11.3 percent) (fig. 11). Comparatively high levels of $\mathrm{BaP}(0.53 \mu \mathrm{g} / \mathrm{g} \mathrm{ww})$ were noted in a largemouth bass (LMB5CAMP, fish ID 32), and its percent $\mathrm{WBCs}$ is relatively low at 1.3 percent as compared with the average value for all largemouth bass (6.5 percent SE 1.6). One largemouth bass (LMB10COUBA, fish ID 21) had 22 percent WBCs and was one of two (LMB24CATA, fish ID 12) of the largemouth bass containing at least eight detectable PAH compounds (app. 1, table 1-6). Fish ID 21 also had levels of mercury and cadmium at more than half the 85th percentile from the NCBP (Schmitt and Brumbaugh, 1990). These percentages of WBCs in largemouth bass reflect an immunosuppressed and immunoreactive response by fish ID 32 and fish ID 21, respectively. Additionally, parasites were noted on the gills and body of another largemouth bass (LMB5CAMP, fish ID 32); parasites are sometimes used as a bioindicator in programs that monitor environmental contaminants (Adams and others, 1990; Khan and Billiard, 2007). The presence of parasites underscores the immunosuppressed condition.

With increasing levels of total AHs (fig. 12) (app. 1, table 1-7), lowering of WBC percentages was significantly greater in largemouth bass than in catfish or mullet. For individual AH compounds, there was an interaction between fish species and n-decane, and mullet and largemouth bass had significantly higher levels than did catfish $(P=0.0175)$.

In this study, mullet (primarily from the Mississippi River) contained the highest levels of aluminum; two eaglets from the pond area showed detectable aluminum levels (see figs. 13 and 14).

In the current study, the mullet, which is planktivorous, contained detectable arsenic for which the range was from 0.72 to $2.6 \mu \mathrm{g} / \mathrm{g} \mathrm{dw}$ (or 0.21 to $0.75 \mu \mathrm{g} / \mathrm{g}$ ww estimated) (fig. 15), which is above the NCBP 85th percentile (Schmitt and Brumbaugh, 1990). The range for mussels was from $3.54 \mu \mathrm{g} / \mathrm{g} \mathrm{dw}$ (1.03 ww estimated) to $15.03 \mu \mathrm{g} / \mathrm{g} \mathrm{dw}$ (4.34 ww estimated). In the 1995-96 BEST study, the greatest concentrations of arsenic were $0.30-0.56 \mu \mathrm{g} / \mathrm{g}$, and one of the stations exhibiting a high amount was Luling, La., the southernmost station in this national study (Schmitt, 2002). 


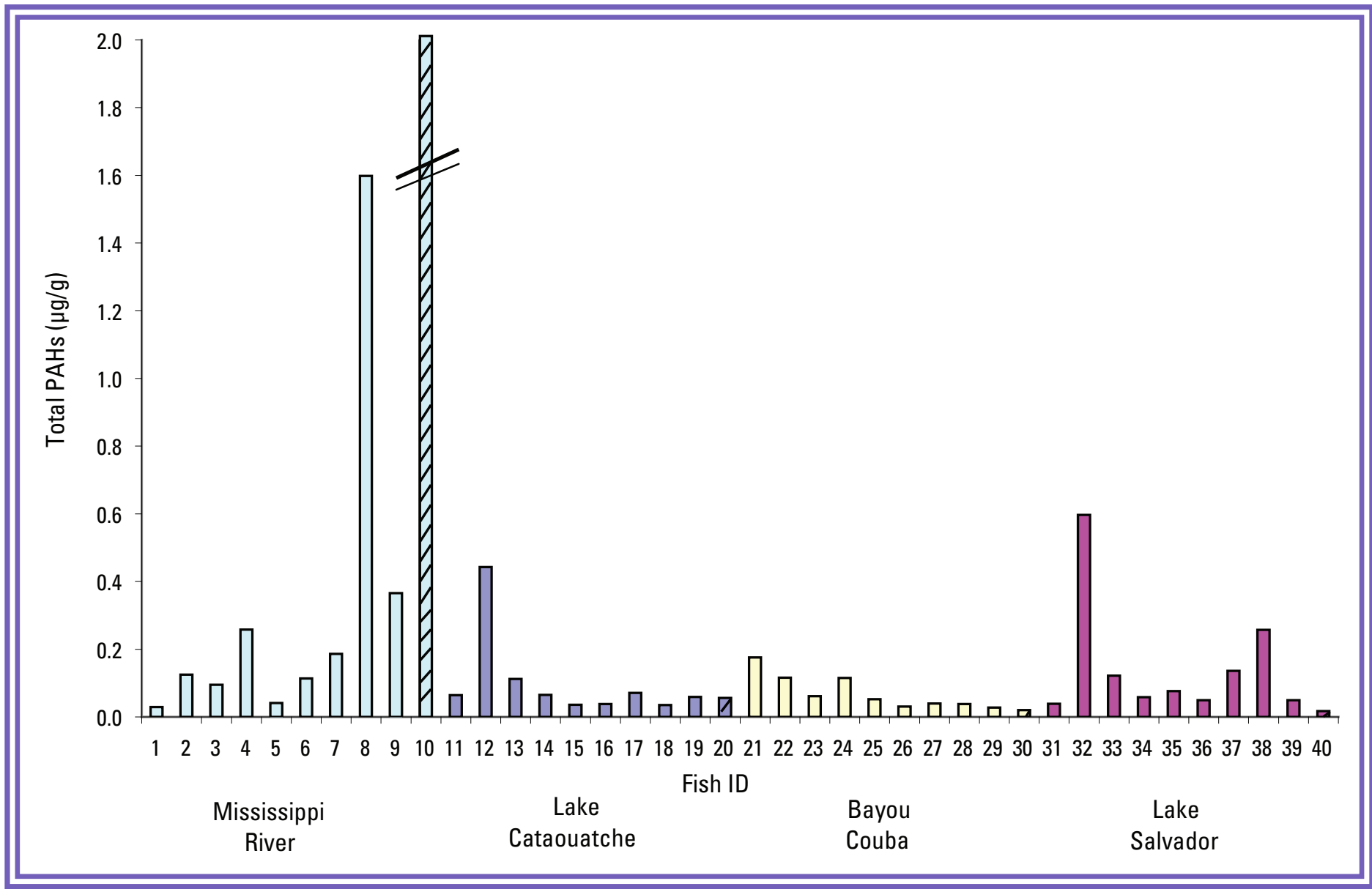

Figure 10. Total polycyclic
aromatic hydrocarbons
(PAHs) from aquatic animal
tissues collected at sites
in southeastern Louisiana
from January through June
2001. Lower limit of detection
was 0.010 parts per million
wet weight. Striped bars
represent values for bivalves.
Quality control of data
checked by the U.S. Fish and
Wildlife Service Analytical
Control Facility.

\begin{tabular}{|c|c|c|c|c|c|}
\hline Fish ID & Sample ID & Total PAHs & Fish ID & Sample ID & Total PAHs \\
\hline 1 & LMB33RIVER & 0.029 & 21 & LMB10COUBA & 0.176 \\
\hline 2 & LMB34RIVER & 0.125 & 22 & LMB11COUBA & 0.116 \\
\hline 3 & LMB35RIVER & 0.095 & 23 & LMB3COUBA & 0.061 \\
\hline 4 & CAT38RIVER & 0.258 & 24 & CAT12COUBA & 0.115 \\
\hline 5 & CAT36RIVER & 0.041 & 25 & CAT13COUBA & 0.052 \\
\hline 6 & CAT37RIVER & 0.114 & 26 & CAT14COUBA & 0.031 \\
\hline 7 & MUL30RIVER & 0.186 & 27 & MUL26COUBA & 0.040 \\
\hline 8 & MUL31RIVER & 1.598 & 28 & MUL27COUBA & 0.038 \\
\hline 9 & MUL32RIVER & 0.366 & 29 & MUL28COUBA & 0.028 \\
\hline 10 & MUSSRIVER & 17.534 & 30 & MUSSCOUBA & 0.020 \\
\hline 11 & LMB21CATA & 0.064 & 31 & LMB4CAMP & 0.039 \\
\hline 12 & LMB24CATA & 0.443 & 32 & LMB5CAMP & 0.597 \\
\hline 13 & LMB25CATA & 0.112 & 33 & LMB6CAMP & 0.122 \\
\hline 14 & CAT22CATA & 0.065 & 34 & CAT1CAMP & 0.058 \\
\hline 15 & CAT23CATA & 0.036 & 35 & CAT2CAMP & 0.076 \\
\hline 16 & CAT7CATA & 0.038 & 36 & САТЗСАМР & 0.049 \\
\hline 17 & MUL18CATA & 0.071 & 37 & MUL15CAMP & 0.136 \\
\hline 18 & MUL19CATA & 0.035 & 38 & MUL16CAMP & 0.257 \\
\hline 19 & MUL20CATA & 0.059 & 39 & MUL17CAMP & 0.049 \\
\hline 20 & MUSSCATA & 0.056 & 40 & MUSSCAMP & 0.017 \\
\hline
\end{tabular}




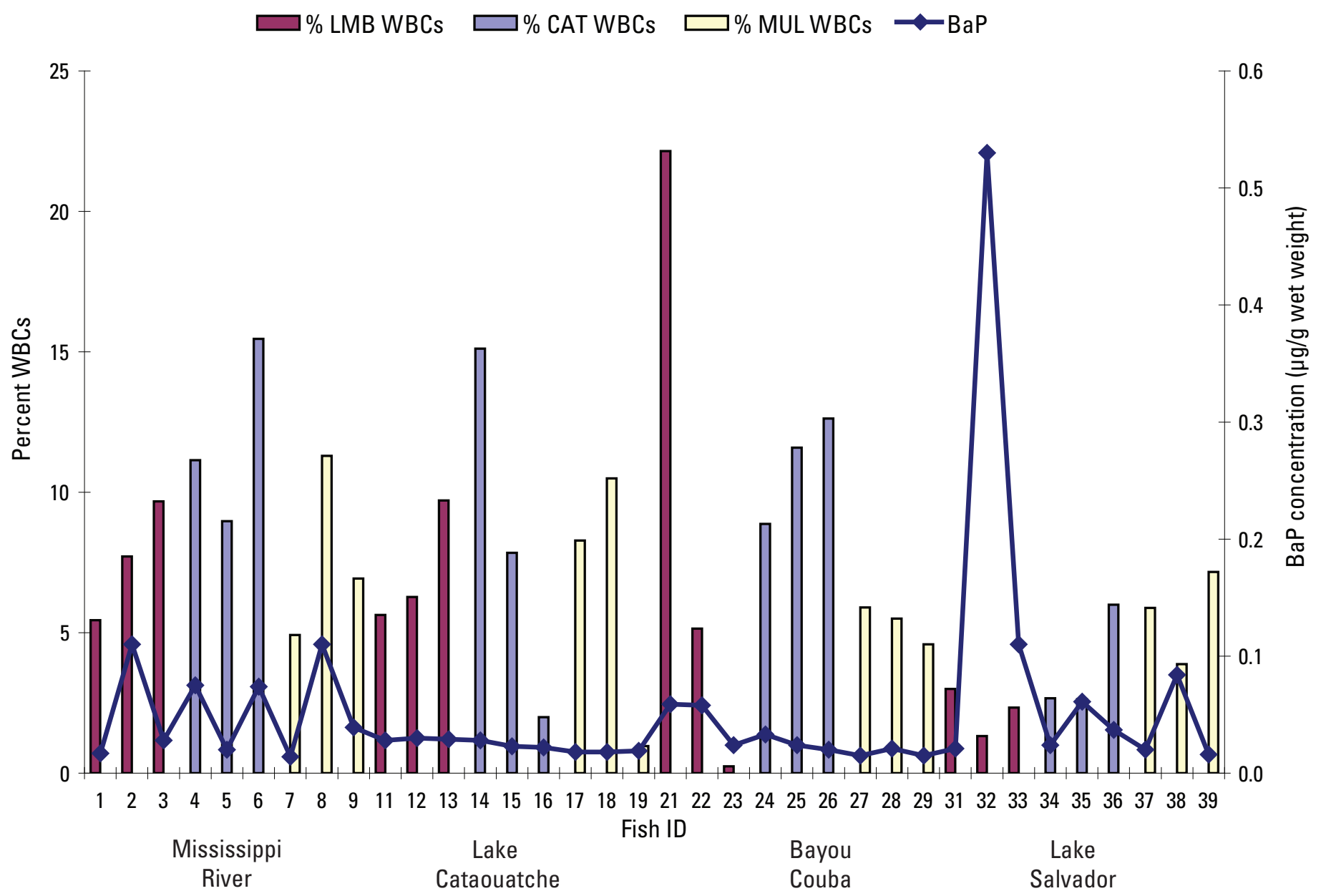

Figure 11. Percent white blood cells (WBCs) in peripheral blood from individual largemouth bass (LMB), blue catfish (CAT), and striped mullet (MUL) plotted against whole body benzo(a)pyrene (BaP) concentrations. 


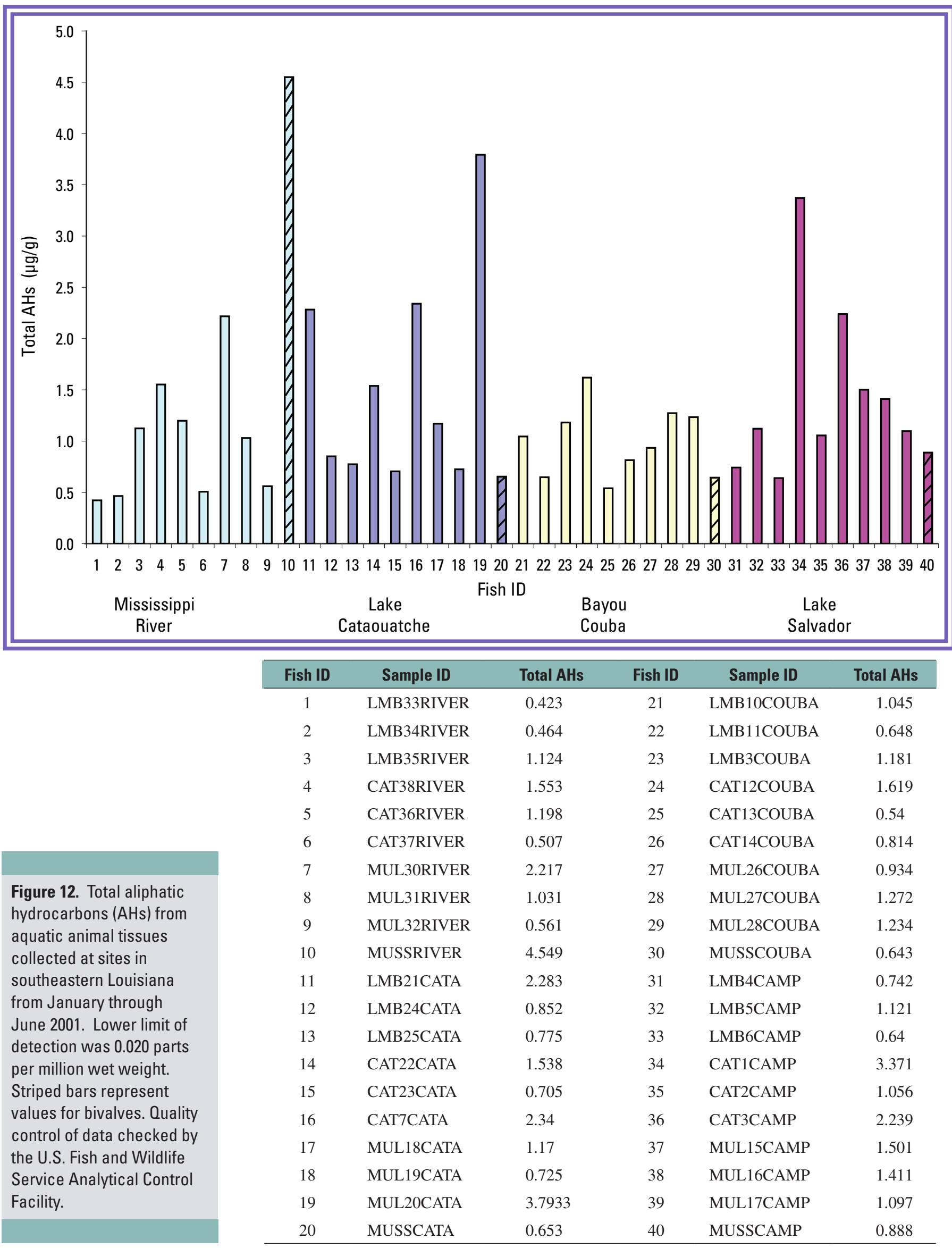




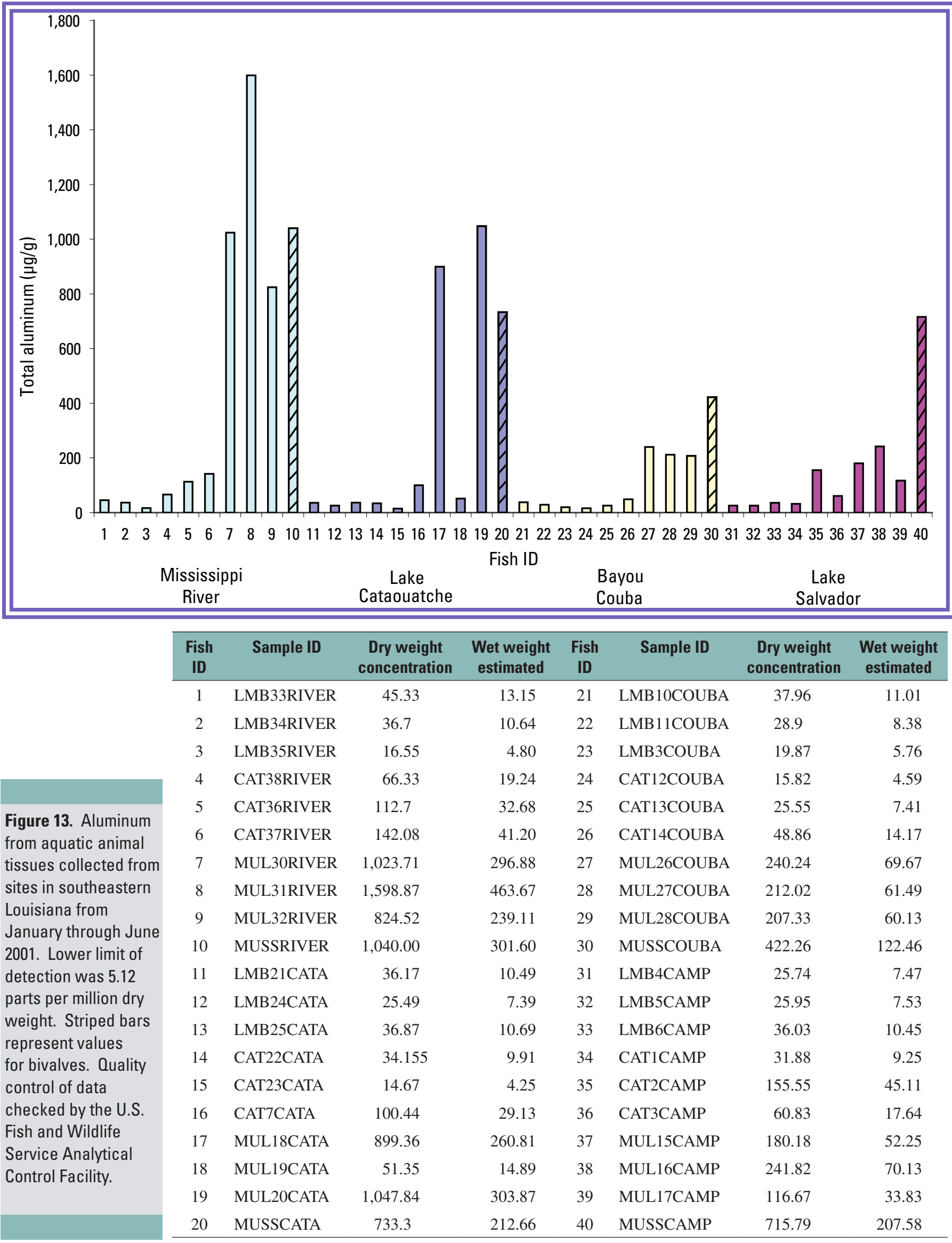




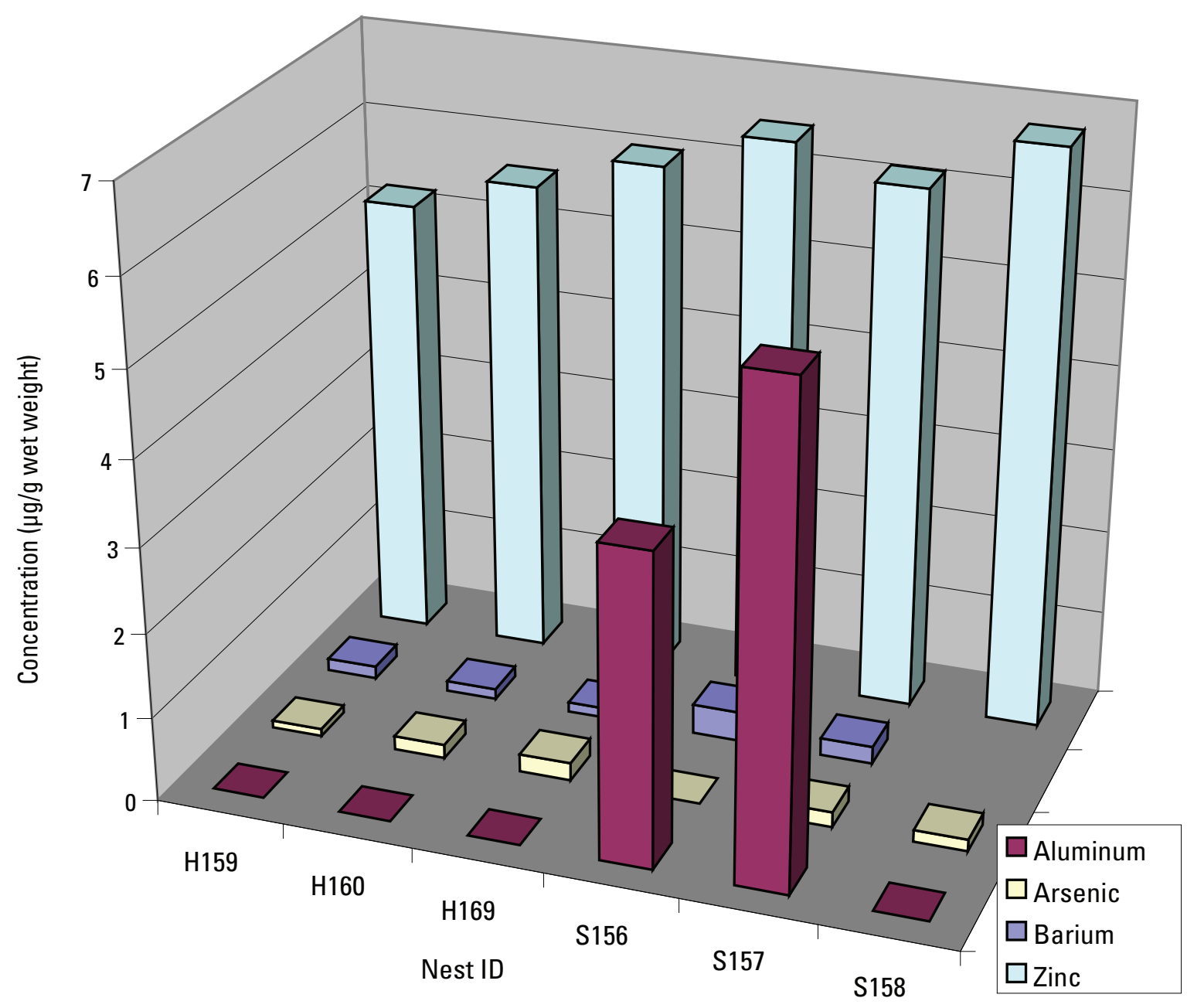

Figure 14. Concentrations of aluminum, arsenic, barium, and zinc from eaglet whole blood collected in southeastern Louisiana from January through June 2001.

The NCBP program lists the 85th percentile for arsenic as $0.27 \mu \mathrm{g} / \mathrm{g}$ ww. In the EMAP study (Summers, 2001) (see fig. 16), a composite from the Davis Pond area contained 0.543 $\mu \mathrm{g} / \mathrm{g}$ ww arsenic (table 6). In the current study, five of the six eaglet blood samples had detectable levels of arsenic with a maximum of $0.212 \mu \mathrm{g} / \mathrm{g}$ ww (fig. 14).

In the 1995-96 BEST study (Schmitt, 2002), barium concentrations were elevated in several samples, but there were few geographic trends. In the current study, each sample had a detectable level of barium, with mullet displaying the most elevated levels at Mississippi River (fig. 17). In all, the range of barium was $1.3-152.4 \mu \mathrm{g} / \mathrm{g} \mathrm{dw}$ or $0.38-44.2 \mu \mathrm{g} / \mathrm{g}$ ww (estimated). Mullet generally showed more elevated levels of barium than did mussels. Each eaglet had detectable barium levels in their blood, up to as much as $0.352 \mu \mathrm{g} / \mathrm{g} \mathrm{ww}$ (fig. 14).

In the current study, the levels of boron reported for the fish and mussels (fig. 18) were not indicative of elevated boron levels in the aquatic environment, and no detectable levels of boron were found in any of the eaglet blood samples.

In the current study, the cadmium levels reached $0.15 \mu \mathrm{g} / \mathrm{g}$ $\mathrm{dw}$ (about $0.04 \mu \mathrm{g} / \mathrm{g} \mathrm{fw}$ ) in fish and up to $2.51 \mu \mathrm{g} / \mathrm{g} \mathrm{dw}$ (about $0.73 \mu \mathrm{g} / \mathrm{g} \mathrm{fw}$ ) in mussels (MUSSRIVER, fish ID 10) (fig. 19). Of the fish having levels above the cadmium detection limit, 80 percent of those came from the Mississippi River site (fig. 19). One of the six eaglets had detectable levels of cadmium 


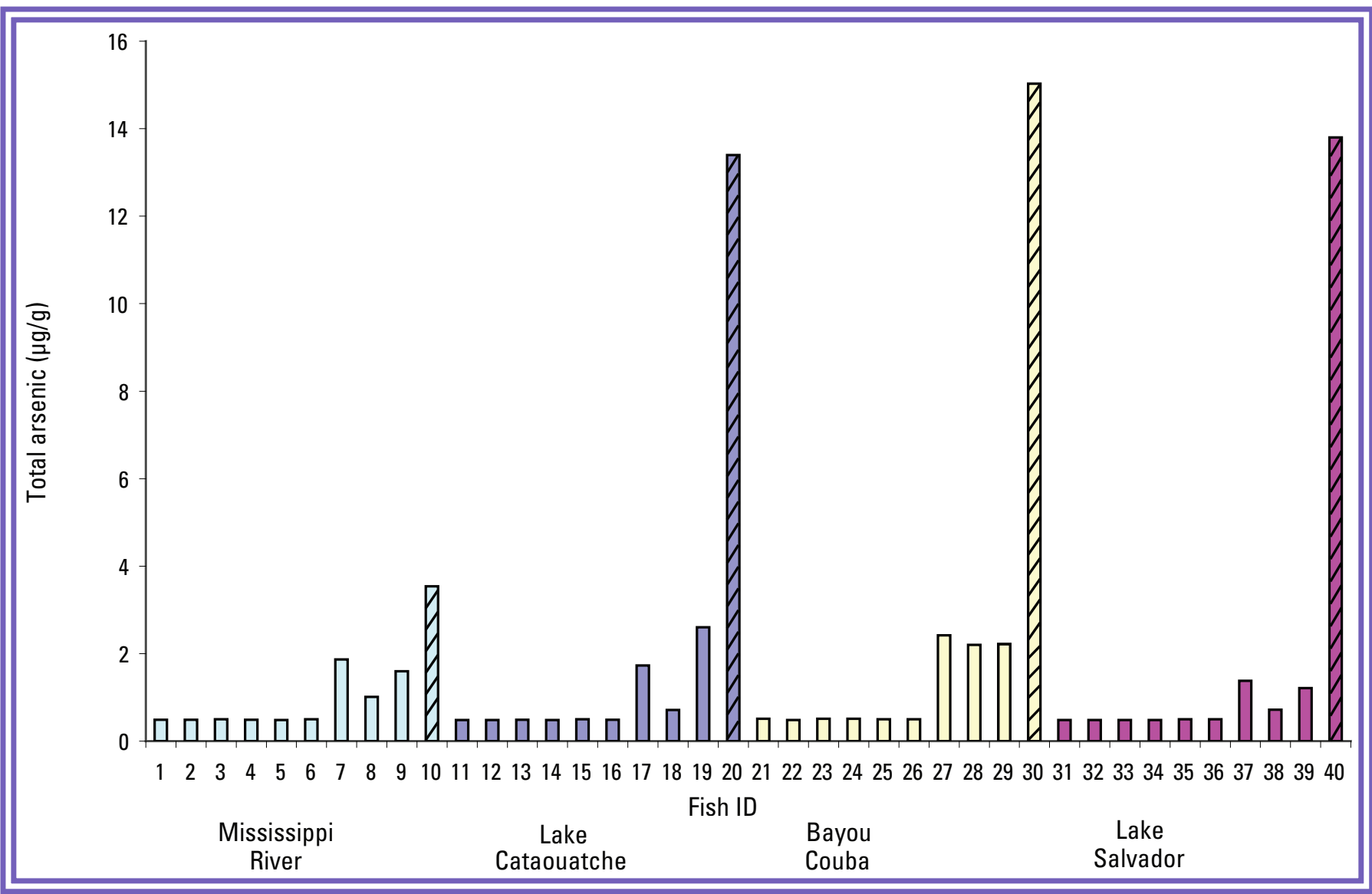

Figure 15. Arsenic
from aquatic animal
tissues collected from
sites in southeastern
Louisiana from
January through
June 2001. Lower
limit of detection
was 0.48 parts per
million dry weight.
Striped bars represent
values for bivalves.
Quality control of
data checked by the
U.S. Fish and Wildlife
Service Analytical
Control Facility.

\begin{tabular}{clcccccc}
\hline $\begin{array}{c}\text { Fish } \\
\text { ID }\end{array}$ & Sample ID & $\begin{array}{c}\text { Dry weight } \\
\text { concentration }\end{array}$ & $\begin{array}{c}\text { Wet weight } \\
\text { estimated }\end{array}$ & $\begin{array}{c}\text { Fish } \\
\text { ID }\end{array}$ & Sample ID & $\begin{array}{c}\text { Dry weight } \\
\text { concentration }\end{array}$ & $\begin{array}{c}\text { Wet weight } \\
\text { estimated }\end{array}$ \\
\hline 1 & LMB33RIVER & $<0.49$ & 0.14 & 21 & LMB10COUBA & 0.51 & 0.15 \\
2 & LMB34RIVER & $<0.49$ & 0.14 & 22 & LMB11COUBA & $<0.48$ & 0.14 \\
3 & LMB35RIVER & $<0.5$ & 0.15 & 23 & LMB3COUBA & $<0.51$ & 0.15 \\
4 & CAT38RIVER & $<0.49$ & 0.14 & 24 & CAT12COUBA & $<0.51$ & 0.15 \\
5 & CAT36RIVER & $<0.48$ & 0.14 & 25 & CAT13COUBA & $<0.5$ & 0.15 \\
6 & CAT37RIVER & $<0.5$ & 0.15 & 26 & CAT14COUBA & $<0.5$ & 0.15 \\
7 & MUL30RIVER & 1.87 & 0.54 & 27 & MUL26COUBA & 2.42 & 0.70 \\
8 & MUL31RIVER & 1.01 & 0.29 & 28 & MUL27COUBA & 2.2 & 0.64 \\
9 & MUL32RIVER & 1.6 & 0.46 & 29 & MUL28COUBA & 2.22 & 0.64 \\
10 & MUSSRIVER & 3.54 & 1.03 & 30 & MUSSCOUBA & 15.03 & 4.36 \\
11 & LMB21CATA & $<0.48$ & 0.14 & 31 & LMB4CAMP & $<0.48$ & 0.14 \\
12 & LMB24CATA & $<0.48$ & 0.14 & 32 & LMB5CAMP & $<0.48$ & 0.14 \\
13 & LMB25CATA & $<0.49$ & 0.14 & 33 & LMB6CAMP & $<0.48$ & 0.14 \\
14 & CAT22CATA & $<0.485$ & 0.14 & 34 & CAT1CAMP & $<0.48$ & 0.14 \\
15 & CAT23CATA & $<0.5$ & 0.15 & 35 & CAT2CAMP & $<0.5$ & 0.15 \\
16 & CAT7CATA & $<0.49$ & 0.14 & 36 & CAT3CAMP & $<0.5$ & 0.15 \\
17 & MUL18CATA & 1.73 & 0.50 & 37 & MUL15CAMP & 1.38 & 0.40 \\
18 & MUL19CATA & 0.71 & 0.21 & 38 & MUL16CAMP & 0.72 & 0.21 \\
19 & MUL20CATA & 2.6 & 0.75 & 39 & MUL17CAMP & 1.21 & 0.35 \\
20 & MUSSCATA & 13.4 & 3.89 & 40 & MUSSCAMP & 13.8 & 4.00 \\
\hline
\end{tabular}




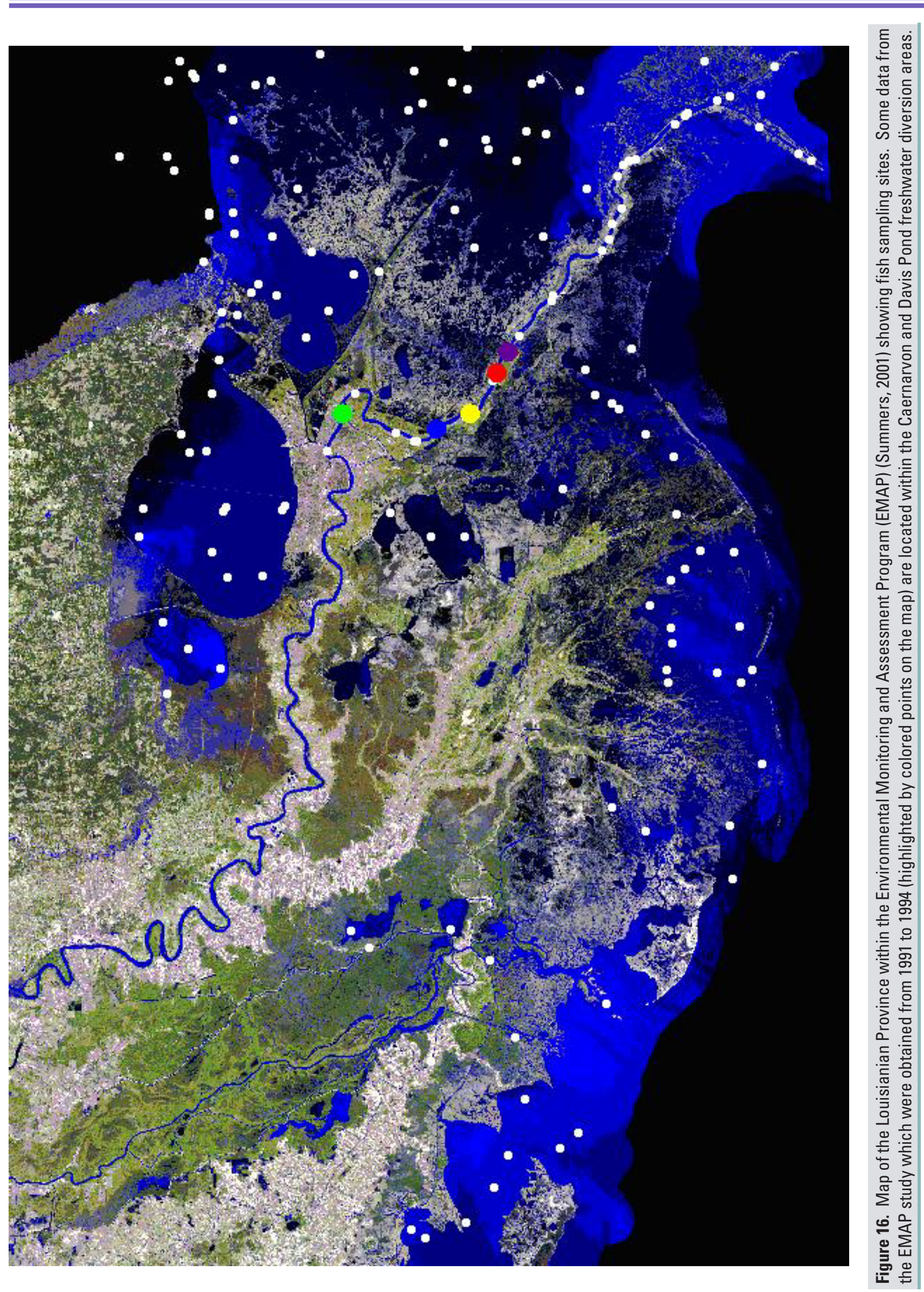


Table 6. Elements data ( $\mu \mathrm{g} / \mathrm{g}$, wet weight) from the Environmental Monitoring and Assessment Program (EMAP; Summers, 2001) fillet composites from sampling stations within the Louisianian Province whose points fall within Caernarvon and Davis Pond areas.

[Data not available for barium, boron, magnesium, manganese, strontium, and vanadium; stations are color coded as in figure 16; N.D., no data]

\begin{tabular}{ccccccccccccc}
\hline Station ID & Aluminum & Arsenic & Cadmium & Chromium & Copper & Iron & Mercury & Nickel & Lead & Selenium & Zinc \\
\hline LA92RR08 & N.D. & 0.543 & N.D. & N.D. & N.D. & 5.278 & 0.880 & 0.369 & 0.022 & 0.174 & 13.032 \\
\hline LA94RR08 & 1.089 & 0.158 & 0.001 & 0.244 & 0.154 & 0.535 & 0.050 & 0.026 & 0.002 & 0.335 & 2.930 \\
LA92RR10 & 1.043 & 0.065 & 0.195 & 0.261 & 0.391 & 8.970 & 0.170 & 0.543 & 0.022 & 0.174 & 3.323 \\
LA91RR08 & N.D. & N.D. & N.D. & N.D. & N.D. & N.D. & N.D. & N.D. & N.D. & N.D. & N.D. \\
LA91RR07 & 1.15 & 0.042 & 0.042 & 0.021 & 0.293 & 4.055 & 0.012 & 0.063 & N.D. & 0.021 & 4.912 \\
\hline
\end{tabular}

at $0.00621 \mu \mathrm{g} / \mathrm{g}$ ww (about $0.02 \mu \mathrm{g} / \mathrm{g} \mathrm{dw}$ ) (see table 7). In a study of eaglets during breeding season in Oregon (Frenzel, 1985), the geometric mean concentration of cadmium from whole blood was as much as $0.11 \mu \mathrm{g} / \mathrm{g}$ ww.

In the Caernarvon prediversion study (Conzelmann and others, 1996), levels of cadmium in fish reached $0.42 \mu \mathrm{g} / \mathrm{g}$ $\mathrm{dw}$, and in bivalves it reached up to $9.51 \mu \mathrm{g} / \mathrm{g} \mathrm{dw}$. A fish composite from the EMAP study (table 6; Summers, 2001) showed a level $(0.195 \mu \mathrm{g} / \mathrm{g} \mathrm{fw})$ above the 85 th percentile (table 1). In this study, four fish from the Mississippi River showed levels of cadmium (fig. 19) that approached the 85th percentile (table 1).

Under field conditions, birds and other wildlife may consume food containing high cadmium levels, but their diets may contain other compounds that alter the toxicity of cadmium (van Campenhout and others, 2007). In future Davis Pond biomonitoring studies, employing a lower detection limit, approximately $0.05 \mathrm{ppm} \mathrm{dw}$, would allow for a better assessment of cadmium in samples.

In the current study, 50 percent of the aquatic animal tissues exhibited levels above $4 \mu \mathrm{g} / \mathrm{g}$ dw chromium (fig. 20), and each sample contained detectable levels. Mussels generally showed lower levels than did fish. The three highest levels of chromium were detected in mullet from the Mississippi River, with a range of $13.8-21.5 \mu \mathrm{g} / \mathrm{g} \mathrm{dw}$. No eaglet blood samples contained detectable levels of chromium.

In the Caernarvon prediversion studies (Conzelmann and others, 1996), the Mississippi River fish had similar concentrations of chromium to the marsh samples, where maximum concentrations were $92.3 \mu \mathrm{g} / \mathrm{g} \mathrm{dw}(24 \mu \mathrm{g} / \mathrm{g} \mathrm{ww})$ and $95.7 \mu \mathrm{g} / \mathrm{g} \mathrm{dw}(26.6 \mu \mathrm{g} / \mathrm{g} \mathrm{ww})$, respectively. In the Caernarvon postdiversion studies (Conzelmann and others, 1996), as before, the Mississippi River fish showed concentrations of chromium not unlike those of the marsh fish samples. In the EMAP study (Summers, 2001), the amount of chromium in fish samples was as much as $0.261 \mu \mathrm{g} / \mathrm{g}$ ww (table 6).

In the current study, catfish in Bayou Couba showed higher levels of chromium $(P=0.0015)$ than did the largemouth bass or mullet from that site (fig. 20). Mullet from the Mississippi River had significantly higher concentrations of chromium than did mullet at the other three sites $(P=$
0.00167).

In the 1995-96 BEST study (Schmitt, 2002), the concentrations of copper ranged from about 0.4 to $3.8 \mu \mathrm{g} / \mathrm{g}$ with the greatest concentrations at the Luling, La., station. In the current study, 58 percent of the mullet sampled exhibited levels at or above $5.5 \mu \mathrm{g} / \mathrm{g} \mathrm{dw}$ and up to $13.77 \mu \mathrm{g} / \mathrm{g} \mathrm{dw}$ copper (fig. 21). The 85th percentile from the NCBP for copper (Schmitt and Brumbaugh, 1990) was $1.00 \mu \mathrm{g} / \mathrm{g}$ ww (3.4 $\mu \mathrm{g} / \mathrm{g} \mathrm{dw})$. Of the 36 fish sampled in the current study, 33.3 percent showed levels above the 85th percentile reported in NCBP, ranging from 0.98 to $13.77 \mu \mathrm{g} / \mathrm{g} \mathrm{dw}$. In Bayou Couba, catfish showed lower levels of copper $(P=0.0065)$ than did largemouth bass and mullet. Mullet at Lake Cataouatche and Bayou Couba had significantly higher levels of copper than did those at Lake Salvador $(P=0.0004)$. Copper was detectable in each eaglet blood sample but did not indicate unhealthful levels (fig. 22).

In the EMAP study (Summers, 2001), the amount of copper in fish samples was as much as $0.391 \mu \mathrm{g} / \mathrm{g}$ ww. In the Caernarvon prediversion studies (Conzelmann and others, 1996), the Mississippi River fish had higher concentrations of copper than did the marsh fish samples, where maximum levels were $28.1 \mu \mathrm{g} / \mathrm{g} \mathrm{dw}(6.58 \mu \mathrm{g} / \mathrm{g} w \mathrm{w})$ and $11.8 \mu \mathrm{g} / \mathrm{g} \mathrm{dw}$ $(4.22 \mu \mathrm{g} / \mathrm{g} \mathrm{ww})$, respectively. In the Caernarvon postdiversion studies (Conzelmann and others, 1996), higher frequencies of fish samples in the marsh sites showed copper levels as compared with numbers from the marsh sites in the prediversion studies, where the maximum level was $111.2 \mu \mathrm{g} / \mathrm{g}$ $\mathrm{dw}(34.7 \mu \mathrm{g} / \mathrm{g} \mathrm{ww})$ at the Mississippi River and $98.2 \mu \mathrm{g} / \mathrm{g} \mathrm{dw}$ $(32.3 \mu \mathrm{g} / \mathrm{g} \mathrm{ww})$ at the marsh site.

In the Caernarvon prediversion studies (Conzelmann and others, 1996), the maximum levels of iron in the Mississippi River and marsh fish were $640 \mu \mathrm{g} / \mathrm{g} \mathrm{dw}(166.4 \mu \mathrm{g} / \mathrm{g} \mathrm{ww})$ and $633 \mu \mathrm{g} / \mathrm{g} \mathrm{dw}(176 \mu \mathrm{g} / \mathrm{g} \mathrm{ww})$, respectively. In the current study, the highest levels of iron in fish were in mullet in the Mississippi River, with a maximum of $1,443 \mu \mathrm{g} / \mathrm{g} \mathrm{dw}(418$ $\mu \mathrm{g} / \mathrm{g} \mathrm{ww}$ ) (fig. 23). In the Caernarvon postdiversion studies (Conzelmann and others, 1996), maximum levels in the Mississippi River and marsh fish were $116.7 \mu \mathrm{g} / \mathrm{g}$ dw $(21 \mu \mathrm{g} / \mathrm{g}$ ww) and $213 \mu \mathrm{g} / \mathrm{g} \mathrm{dw}(91.6 \mu \mathrm{g} / \mathrm{g} \mathrm{ww})$, respectively. In the 


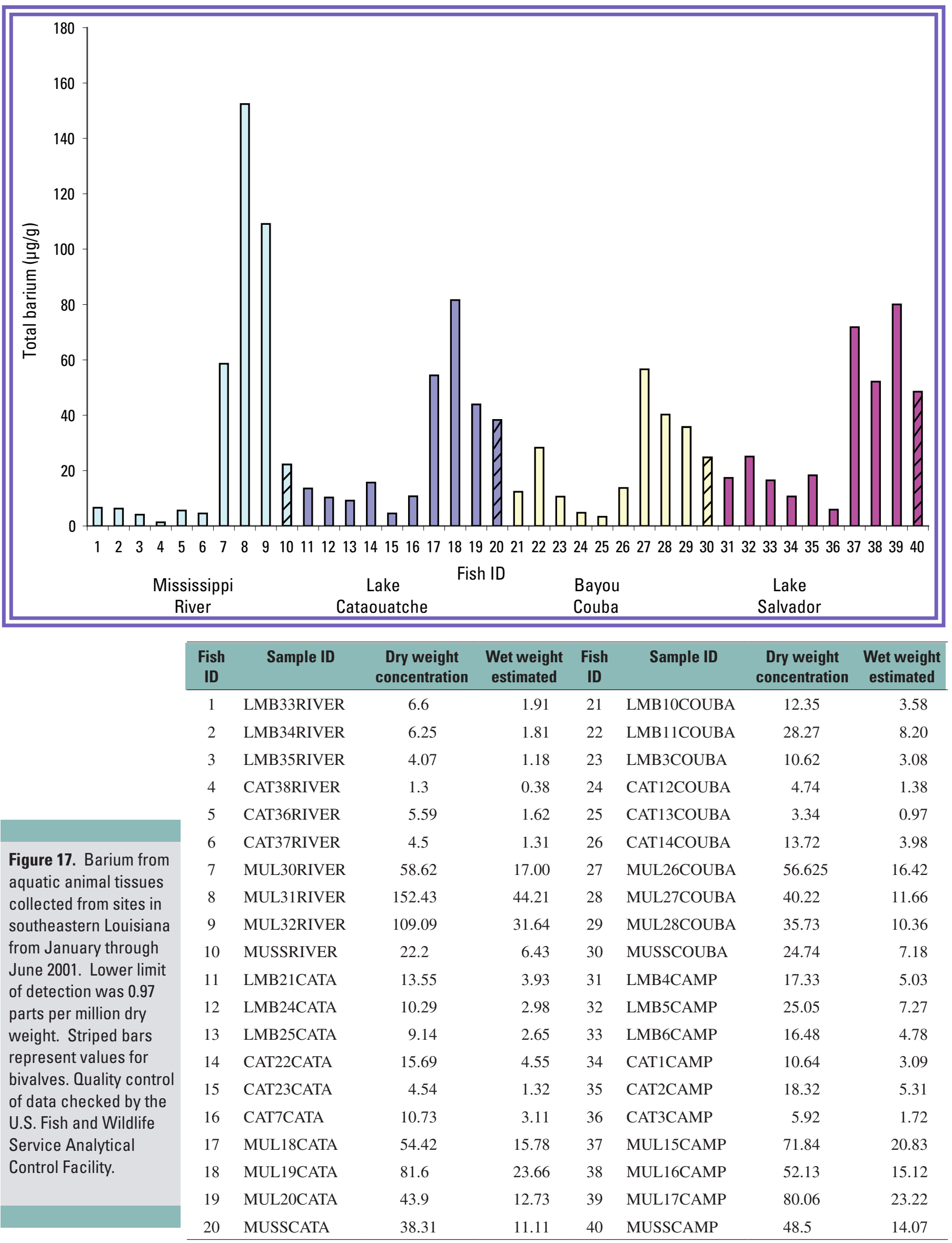




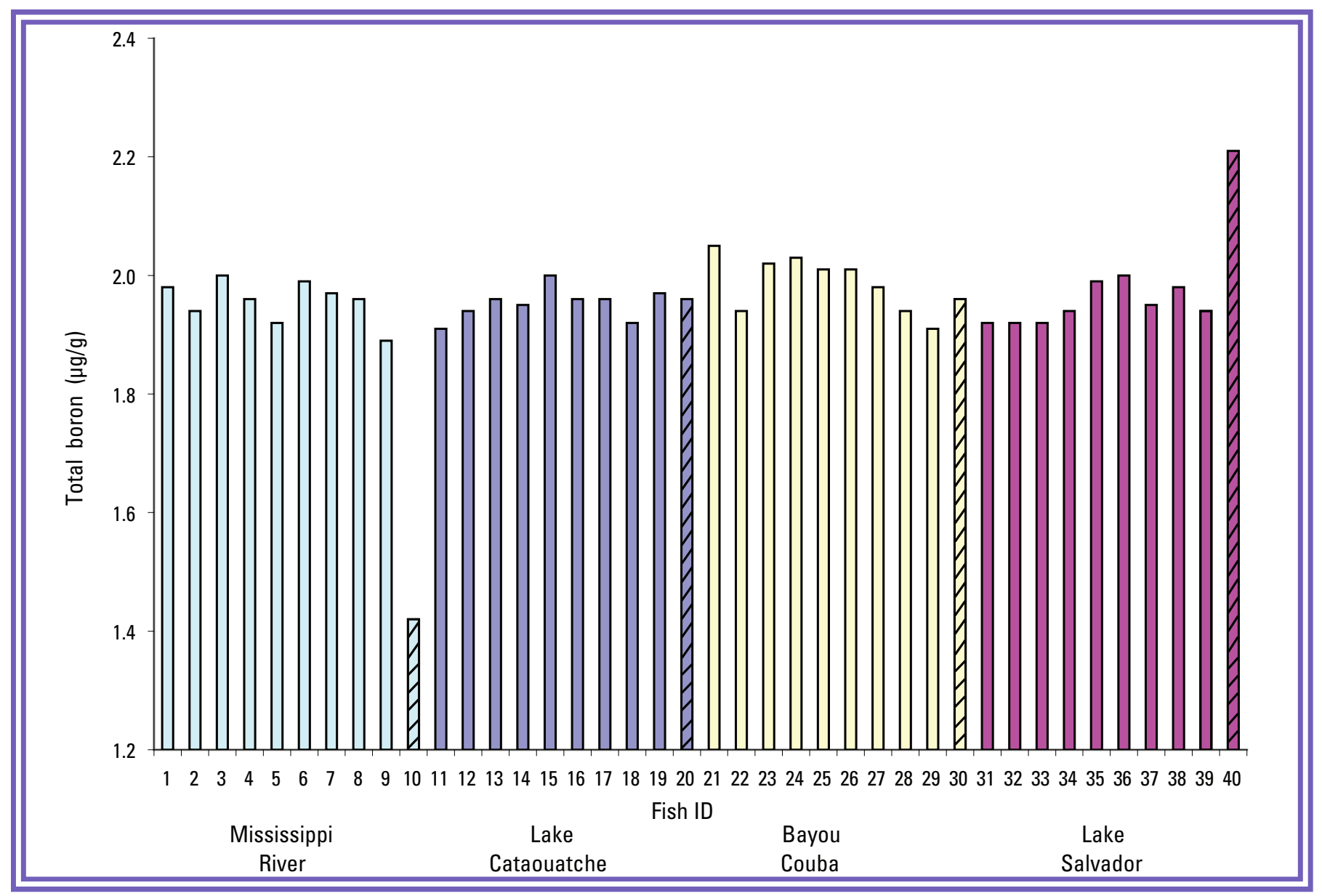

Figure 18. Boron from aquatic animal tissues collected from sites in southeastern Louisiana from January through June 2001. Lower limit of detection was 1.42 parts per million dry weight. Striped bars represent values for bivalves. Quality control of data checked by the U.S. Fish and Wildlife Service Analytical Control Facility.

\begin{tabular}{clccclcc}
\hline $\begin{array}{c}\text { Fish } \\
\text { ID }\end{array}$ & Sample ID & $\begin{array}{c}\text { Dry weight } \\
\text { concentration }\end{array}$ & $\begin{array}{c}\text { Wet weight } \\
\text { estimated }\end{array}$ & $\begin{array}{c}\text { Fish } \\
\text { ID }\end{array}$ & Sample ID & $\begin{array}{c}\text { Dry weight } \\
\text { concentration }\end{array}$ & $\begin{array}{c}\text { Wet weight } \\
\text { estimated }\end{array}$ \\
\hline 1 & LMB33RIVER & 1.98 & 0.57 & 21 & LMB10COUBA & 2.05 & 0.60 \\
2 & LMB34RIVER & 1.94 & 0.56 & 22 & LMB11COUBA & 1.94 & 0.56 \\
3 & LMB35RIVER & 2 & 0.58 & 23 & LMB3COUBA & 2.02 & 0.59 \\
4 & CAT38RIVER & 1.96 & 0.57 & 24 & CAT12COUBA & 2.03 & 0.59 \\
5 & CAT36RIVER & 1.92 & 0.56 & 25 & CAT13COUBA & 2.01 & 0.58 \\
6 & CAT37RIVER & 1.99 & 0.58 & 26 & CAT14COUBA & 2.01 & 0.58 \\
7 & MUL30RIVER & 1.97 & 0.57 & 27 & MUL26COUBA & 1.98 & 0.57 \\
8 & MUL31RIVER & 1.96 & 0.57 & 28 & MUL27COUBA & 1.94 & 0.56 \\
9 & MUL32RIVER & 1.89 & 0.55 & 29 & MUL28COUBA & 1.91 & 0.55 \\
10 & MUSSRIVER & 1.42 & 0.41 & 30 & MUSSCOUBA & 1.96 & 0.57 \\
11 & LMB21CATA & 1.91 & 0.55 & 31 & LMB4CAMP & 1.92 & 0.56 \\
12 & LMB24CATA & 1.94 & 0.56 & 32 & LMB5CAMP & 1.92 & 0.56 \\
13 & LMB25CATA & 1.96 & 0.57 & 33 & LMB6CAMP & 1.92 & 0.56 \\
14 & CAT22CATA & 1.95 & 0.57 & 34 & CAT1CAMP & 1.94 & 0.56 \\
15 & CAT23CATA & 2 & 0.58 & 35 & CAT2CAMP & 1.99 & 0.58 \\
16 & CAT7CATA & 1.96 & 0.57 & 36 & CAT3CAMP & 2 & 0.58 \\
17 & MUL18CATA & 1.96 & 0.57 & 37 & MUL15CAMP & 1.95 & 0.57 \\
18 & MUL19CATA & 1.92 & 0.56 & 38 & MUL16CAMP & 1.98 & 0.57 \\
19 & MUL20CATA & 1.97 & 0.57 & 39 & MUL17CAMP & 1.94 & 0.56 \\
20 & MUSSCATA & 1.96 & 0.57 & 40 & MUSSCAMP & 2.21 & 0.64 \\
\hline
\end{tabular}




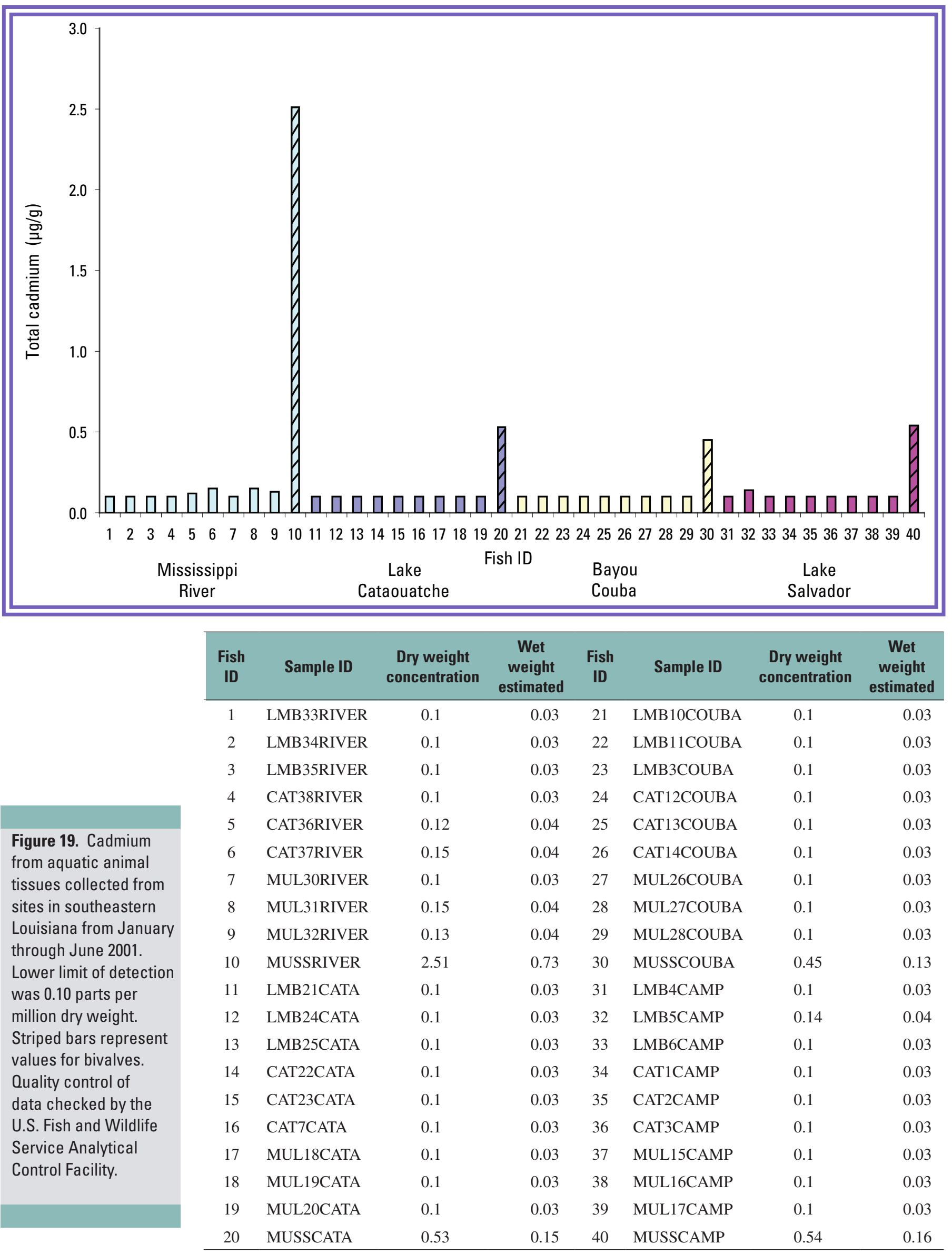


Table 7. Levels of inorganic elements ( $\mu \mathrm{g} / \mathrm{g}$, wet weight) from eaglet blood. Quality control of data checked by the U.S. Fish and Wildlife Service Analytical Control Facility.

[Dots indicate a result that was less than the detection limit]

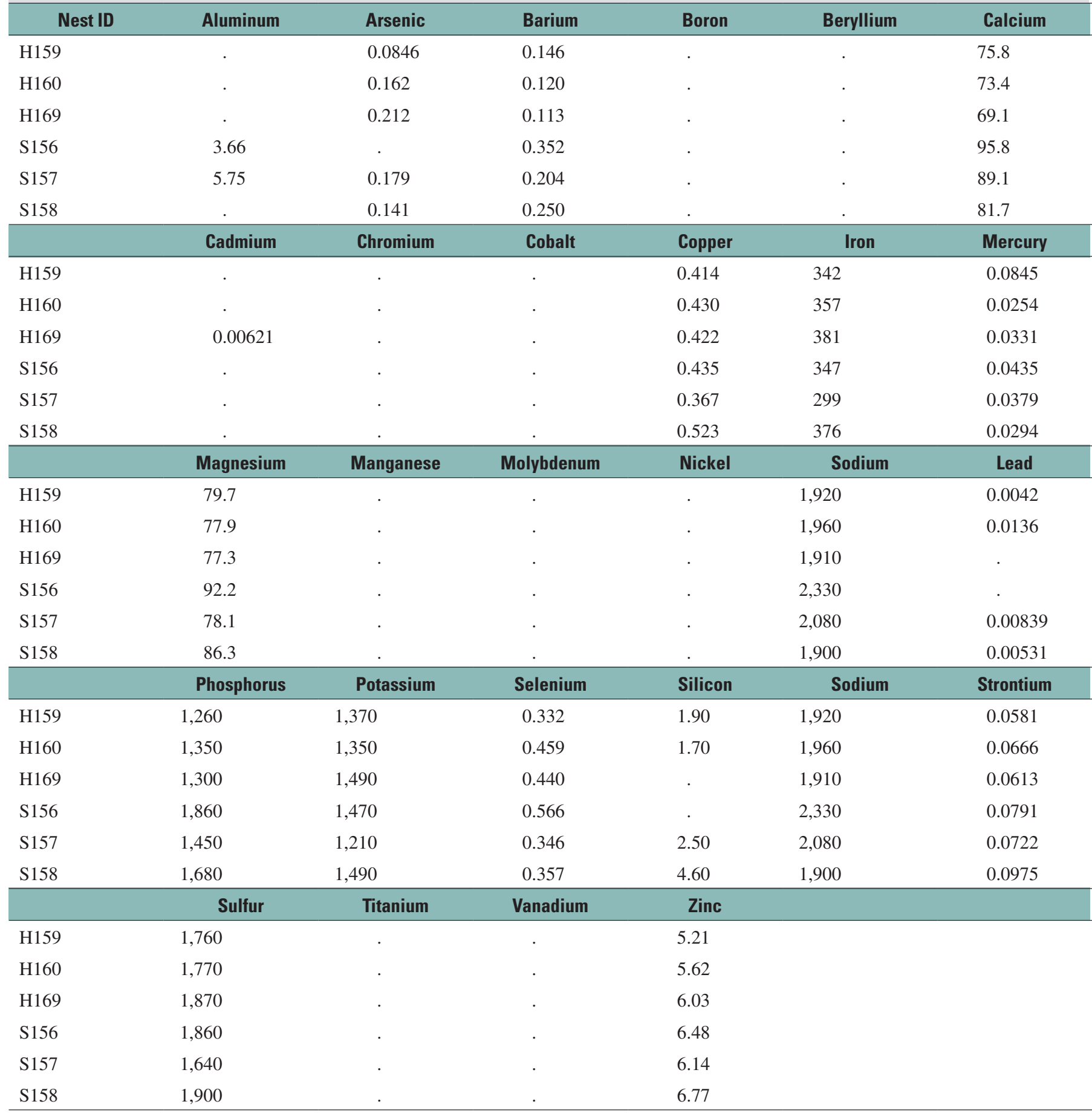




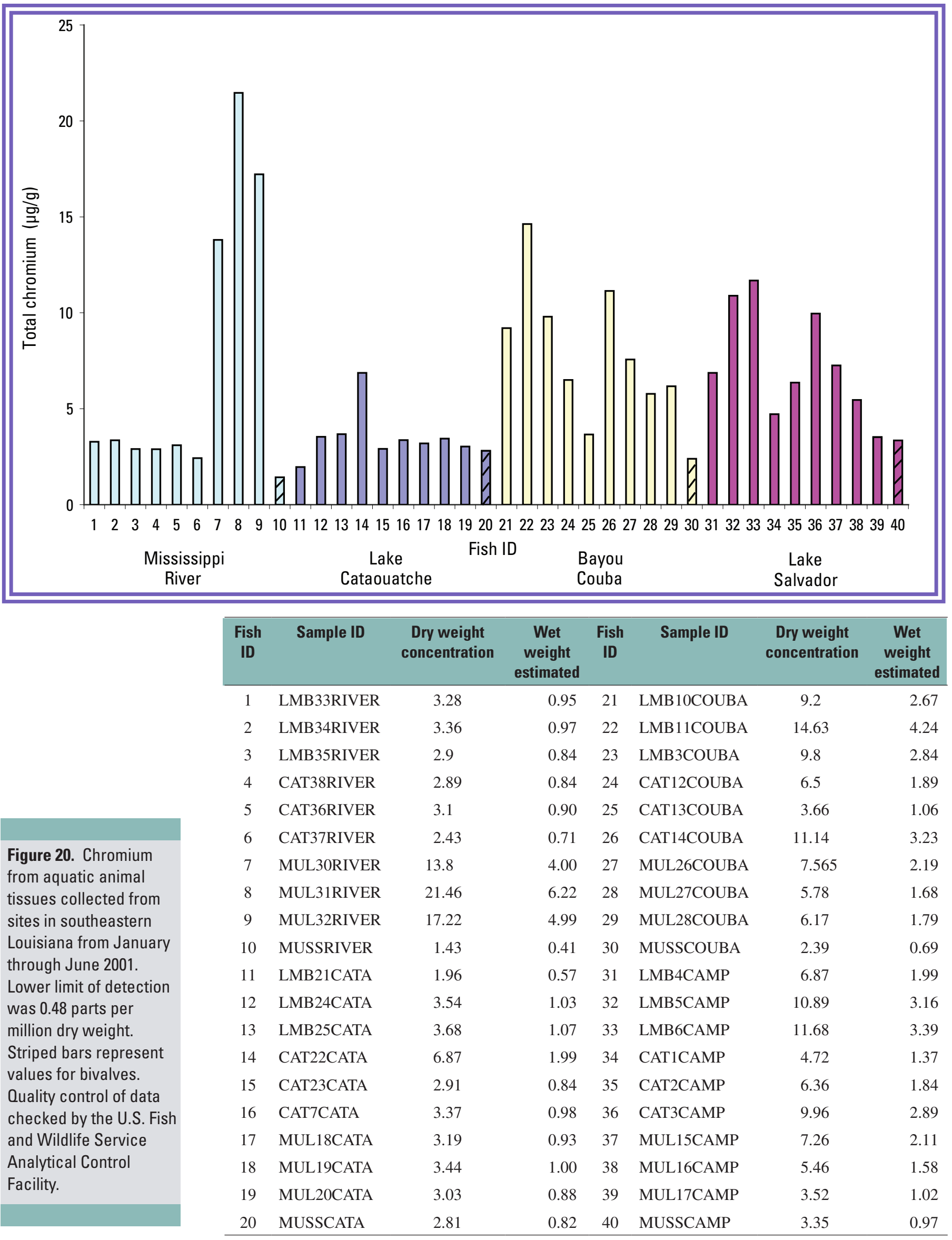




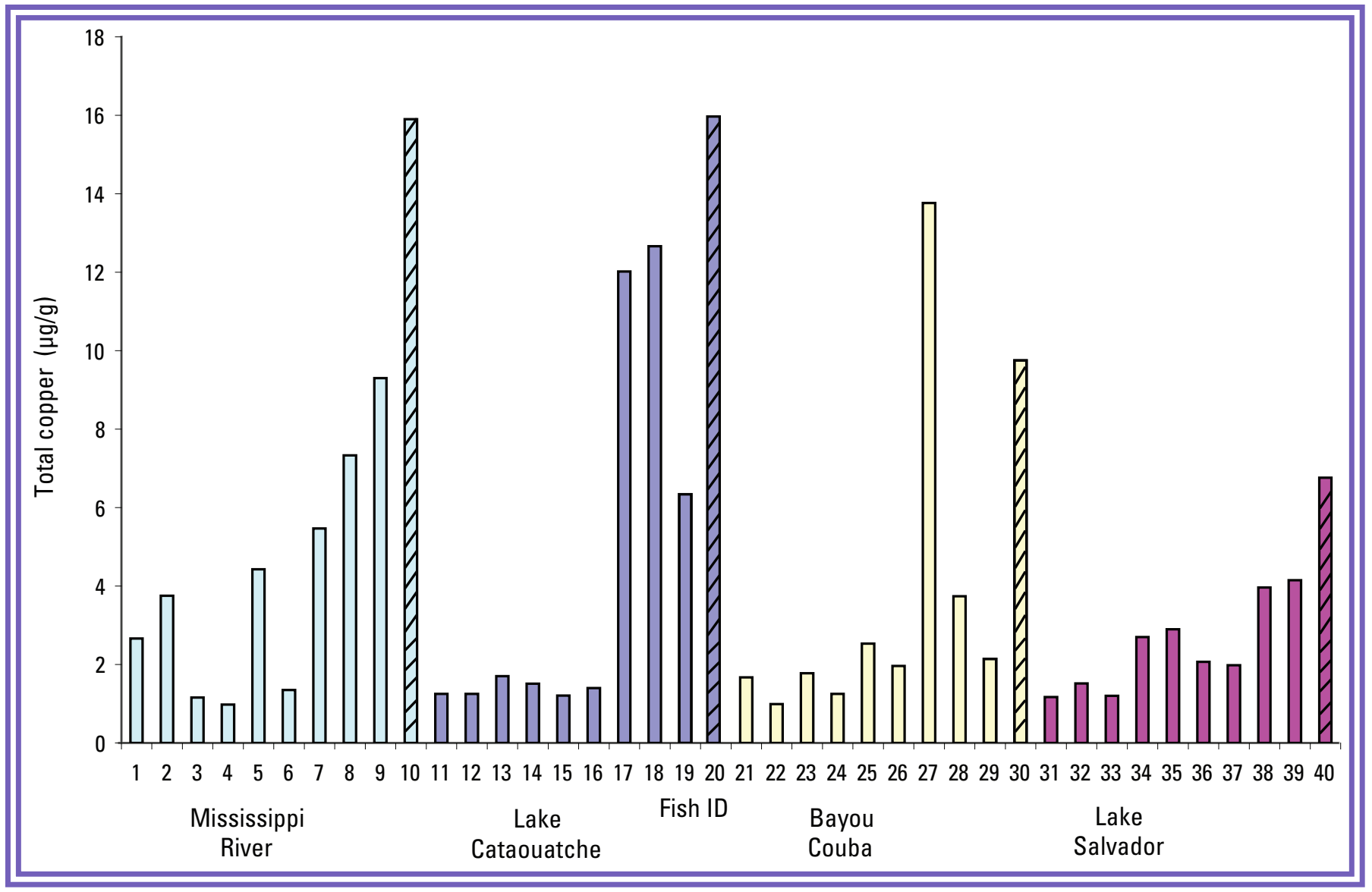

Figure 21. Copper from aquatic animal tissues collected from sites in southeastern Louisiana from January through June 2001. Lower limit of detection was 0.48 parts per million dry weight. Striped bars represent values for bivalves. Quality control of data checked by the U.S. Fish and Wildlife Service Analytical Control Facility.

\begin{tabular}{clccclcc}
\hline $\begin{array}{c}\text { Fish } \\
\text { ID }\end{array}$ & Sample ID & $\begin{array}{c}\text { Dry weight } \\
\text { concentration }\end{array}$ & $\begin{array}{c}\text { Wet weight } \\
\text { estimated }\end{array}$ & $\begin{array}{c}\text { Fish } \\
\text { ID }\end{array}$ & Sample ID & $\begin{array}{c}\text { Dry weight } \\
\text { concentration }\end{array}$ & $\begin{array}{c}\text { Wet weight } \\
\text { estimated }\end{array}$ \\
\hline 1 & LMB33RIVER & 2.66 & 0.77 & 21 & LMB10COUBA & 1.67 & 0.48 \\
2 & LMB34RIVER & 3.75 & 1.09 & 22 & LMB11COUBA & 0.99 & 0.29 \\
3 & LMB35RIVER & 1.16 & 0.34 & 23 & LMB3COUBA & 1.78 & 0.52 \\
4 & CAT38RIVER & 0.98 & 0.28 & 24 & CAT12COUBA & 1.25 & 0.36 \\
5 & CAT36RIVER & 4.43 & 1.29 & 25 & CAT13COUBA & 2.53 & 0.73 \\
6 & CAT37RIVER & 1.35 & 0.39 & 26 & CAT14COUBA & 1.96 & 0.57 \\
7 & MUL30RIVER & 5.47 & 1.59 & 27 & MUL26COUBA & 13.77 & 3.99 \\
8 & MUL31RIVER & 7.33 & 2.13 & 28 & MUL27COUBA & 3.74 & 1.09 \\
9 & MUL32RIVER & 9.3 & 2.70 & 29 & MUL28COUBA & 2.14 & 0.62 \\
10 & MUSSRIVER & 15.9 & 4.76 & 30 & MUSSCOUBA & 9.75 & 2.83 \\
11 & LMB21CATA & 1.25 & 0.36 & 31 & LMB4CAMP & 1.17 & 0.34 \\
12 & LMB24CATA & 1.25 & 0.36 & 32 & LMB5CAMP & 1.52 & 0.44 \\
13 & LMB25CATA & 1.7 & 0.49 & 33 & LMB6CAMP & 1.2 & 0.35 \\
14 & CAT22CATA & 1.51 & 0.44 & 34 & CAT1CAMP & 2.7 & 0.78 \\
15 & CAT23CATA & 1.21 & 0.35 & 35 & CAT2CAMP & 2.9 & 0.84 \\
16 & CAT7CATA & 1.4 & 0.41 & 36 & CAT3CAMP & 2.07 & 0.60 \\
17 & MUL18CATA & 12.02 & 3.49 & 37 & MUL15CAMP & 1.98 & 0.57 \\
18 & MUL19CATA & 12.66 & 3.67 & 38 & MUL16CAMP & 3.96 & 1.15 \\
19 & MUL20CATA & 6.34 & 1.84 & 39 & MUL17CAMP & 4.15 & 1.20 \\
20 & MUSSCATA & 15.97 & 4.63 & 40 & MUSSCAMP & 6.76 & 1.96 \\
\hline
\end{tabular}




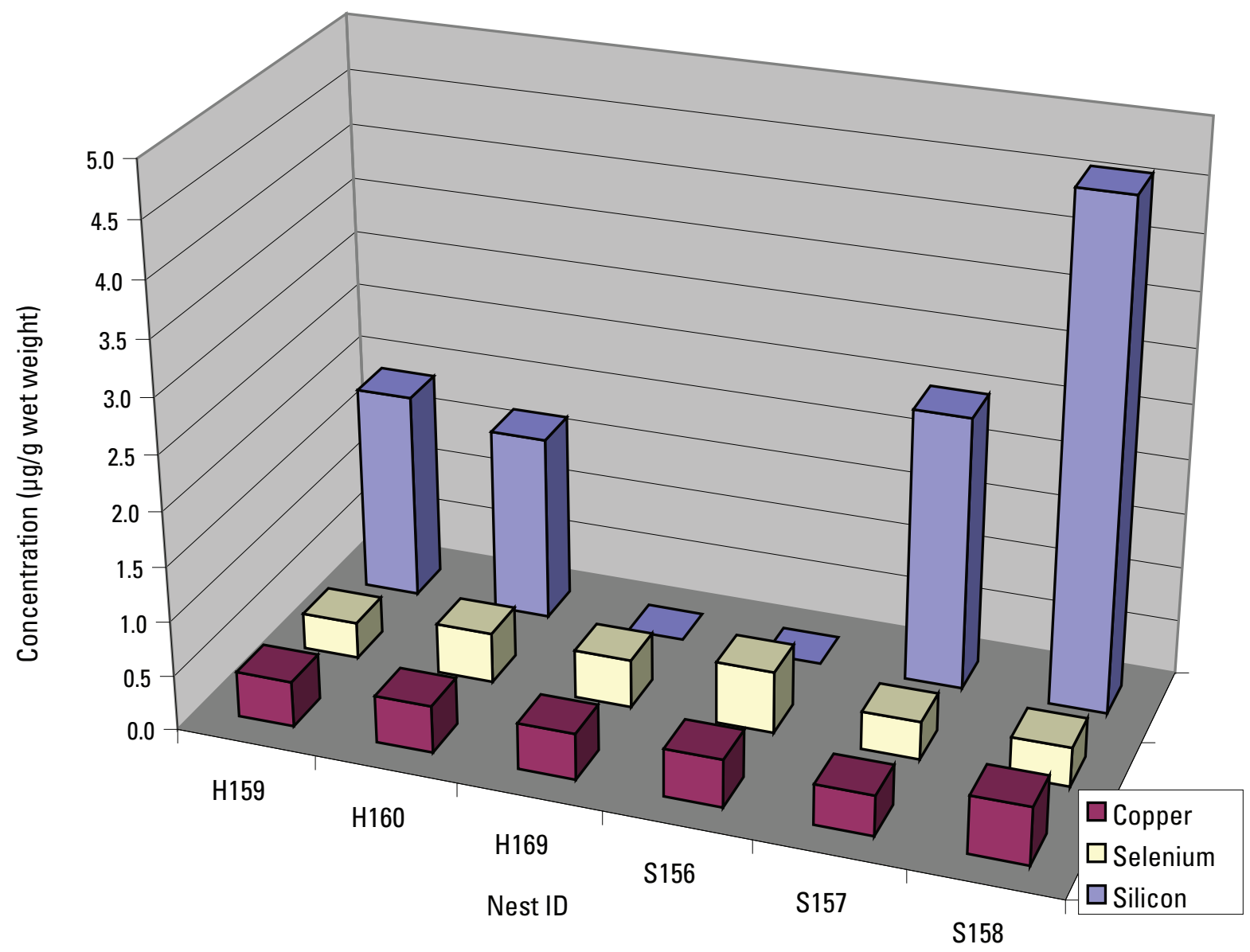

Figure 22. Concentrations of copper, selenium, and silicon from eaglet whole blood collected in southeastern Louisiana from January through June 2001.

EMAP study (table 6; Summers, 2001), the amount of iron in fish samples was up to $8.970 \mu \mathrm{g} / \mathrm{g}$ fw. In eaglets, levels of iron (fig. 24) were higher than serum chemistry values from nestlings in Michigan (Bowerman and others, 2000).

In aquatic animal tissues, the range of concentrations of lead was as much as $18.3 \mu \mathrm{g} / \mathrm{g}$ dw (MUL31RIVER, fish ID 8), with the three most elevated values coming from mullet from the Mississippi River, whereas a catfish from the Mississippi River site upstream of the structure contained $1.53 \mu \mathrm{g} / \mathrm{g} \mathrm{dw}$ (CAT37RIVER, fish ID 6) (fig. 25). In the marsh sites in the current study, a mullet (MUL26COUBA, fish ID 27) showed the highest lead levels at $0.67 \mu \mathrm{g} / \mathrm{g} \mathrm{dw}(0.19 \mu \mathrm{g} / \mathrm{g} w w)$. Eisler (1999) reported elevated levels in fish whole bodies from studies showing $6.7 \mathrm{mg} / \mathrm{kg}$ ww lead and above, and at $0.3 \mu \mathrm{g} / \mathrm{g}$ ww lead in edible tissue is hazardous to human health. In the Caernarvon prediversion studies (Conzelmann and others, 1996), the maximum levels of lead in the Mississippi River and marsh fish were $8.20 \mu \mathrm{g} / \mathrm{g} \mathrm{dw}(1.66 \mu \mathrm{g} / \mathrm{g} \mathrm{ww})$ and $296 \mu \mathrm{g} /$ $\mathrm{kg} \mathrm{dw}(84.7 \mu \mathrm{g} / \mathrm{g} \mathrm{ww})$, respectively. No postdiversion lead levels were reported.

In the current study, eaglet blood values of detectable lead ranged from 0.0042 to $0.0136 \mu \mathrm{g} / \mathrm{g} \mathrm{ww}$ (fig. 26), well below the blood level from waterfowl with elevated $(0.058 \mu \mathrm{g} / \mathrm{kg}$ ww) or poisoned $(0.4 \mathrm{~kg} / \mathrm{L} \mathrm{ww})$ levels of lead (Eisler, 1999). Most cases of lead poisoning in carnivorous birds resulted from ingestion of lead shot in food items (Custer and others, 1984). The maximum amount of lead $(0.0136 \mu \mathrm{g} / \mathrm{g} \mathrm{ww})$ detected in eaglet blood was from a marsh site (fig. 26). This level was well below the levels reported to be injurious to bald eagles (U.S. Geological Survey, 2007b). In the EMAP study (table 6; Summers, 2001), the amount of lead in fish samples was as much as $0.022 \mu \mathrm{g} / \mathrm{g}$ ww.

Magnesium (see figs. 27 and 28 and table 7) is considered a nontoxic metal in the hydrologic environment (Meade, 


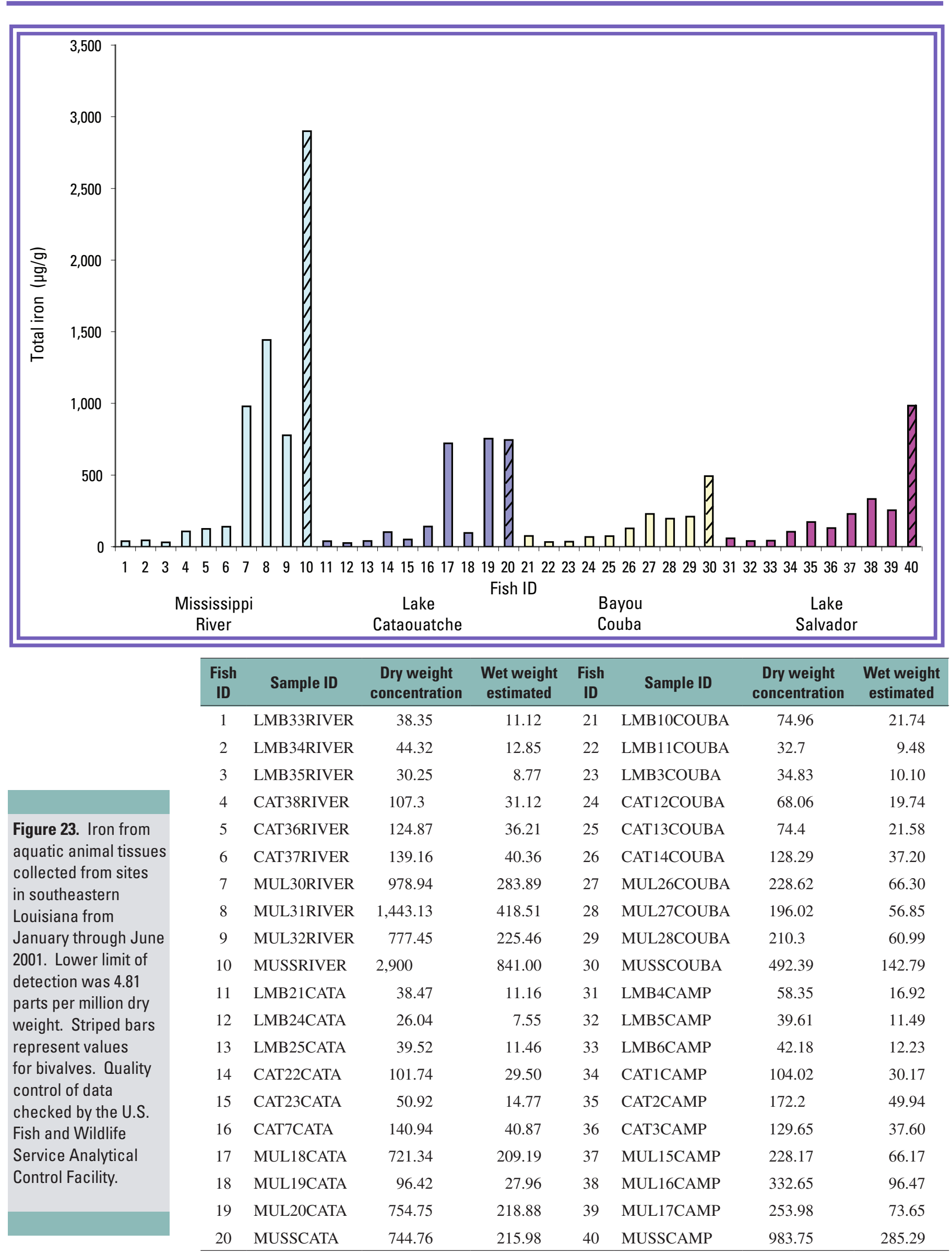




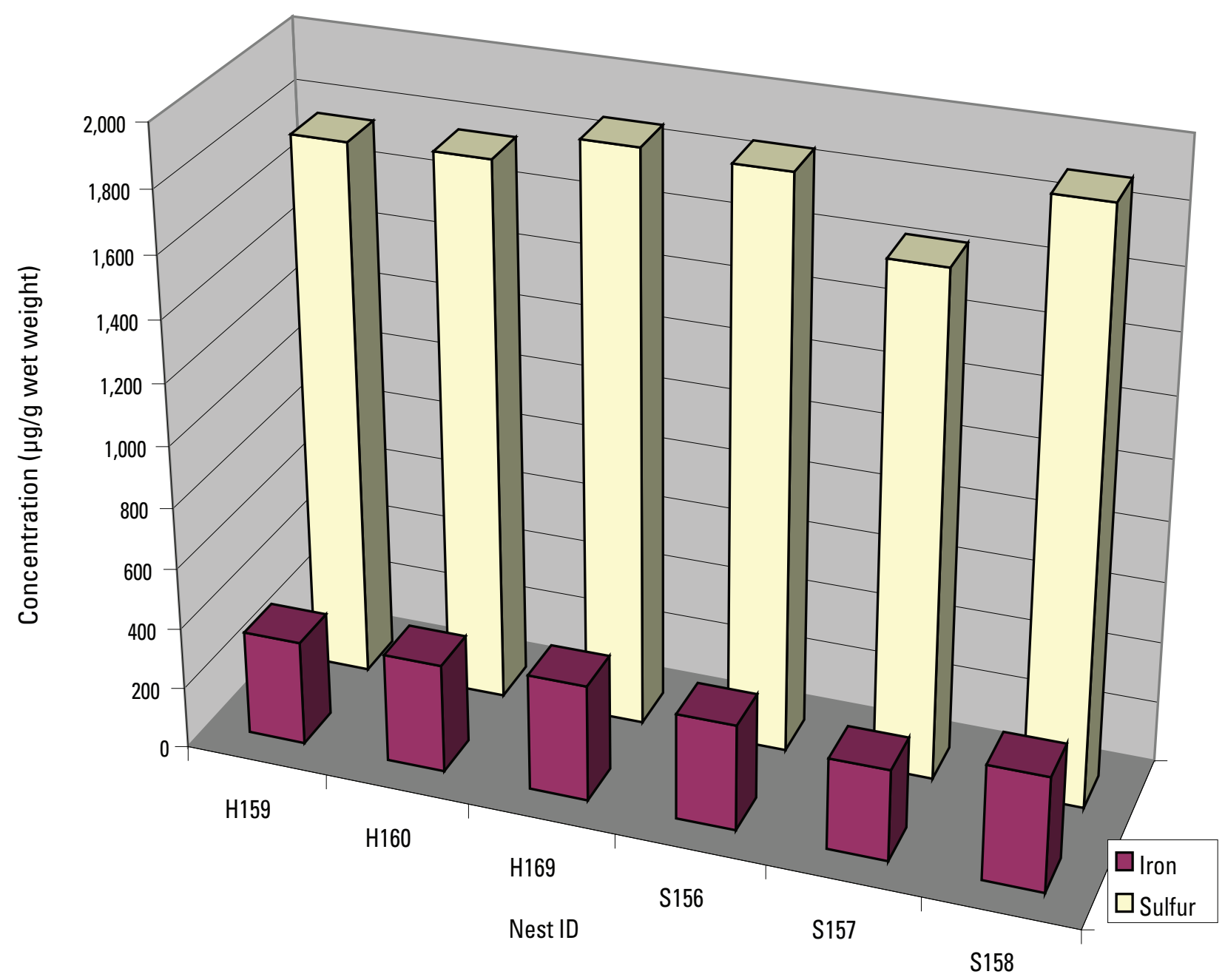

Figure 24. Concentrations of iron and sulfur from eaglet whole blood collected in southeastern Louisiana from January through June 2001.

1995). Ionic forms are essential to the function of chemical mediators, enzymes, and many cellular processes.

Manganese is considered a nontoxic metal in the hydrologic environment (Meade, 1995). In the current study, significantly higher amounts of manganese were found in Mississippi River mullet than in mullet at other sites $(P=$ 0.0008) (fig. 29).

In the current study, 67 percent of the animals sampled showed measurable mercury levels, with a range of 0.14 $0.48 \mu \mathrm{g} / \mathrm{g}$, with the highest levels seen in largemouth bass (LMB6CAMP, fish ID 33) at the point in the diversion area farthest from the Mississippi River (fig. 30). Mercury accumulates with size and age in predatory fishes to a greater extent than most other contaminants (Wiener and Spry,
1996). Some of the mercury levels of fish in the current study approached the 85th percentile of the NCBP (table 1; Schmitt and Brumbaugh, 1990). In the 2002 BEST report (Schmitt, 2002), the highest reported amount of mercury came from the Cache River, Ark. (station 207), in the Mississippi Embayment at about $0.31 \mu \mathrm{g} / \mathrm{g}$. In the EMAP study (table 6; Summers, 2001), the amount of mercury in fish samples was as much as $0.880 \mu \mathrm{g} / \mathrm{g} w w$. In the Caernarvon prediversion studies (Conzelmann and others, 1996), the maximum levels of mercury in the Mississippi River and marsh fish were $0.788 \mu \mathrm{g} / \mathrm{g} \mathrm{dw}(0.23 \mu \mathrm{g} / \mathrm{g}$ ww estimated $)$ and $0.678 \mu \mathrm{g} / \mathrm{g} \mathrm{dw}$ $(0.19 \mu \mathrm{g} / \mathrm{g}$ ww estimated), respectively. In the Caernarvon postdiversion studies (Conzelmann and others, 1996), the maximum levels in the Mississippi River and marsh fish were 


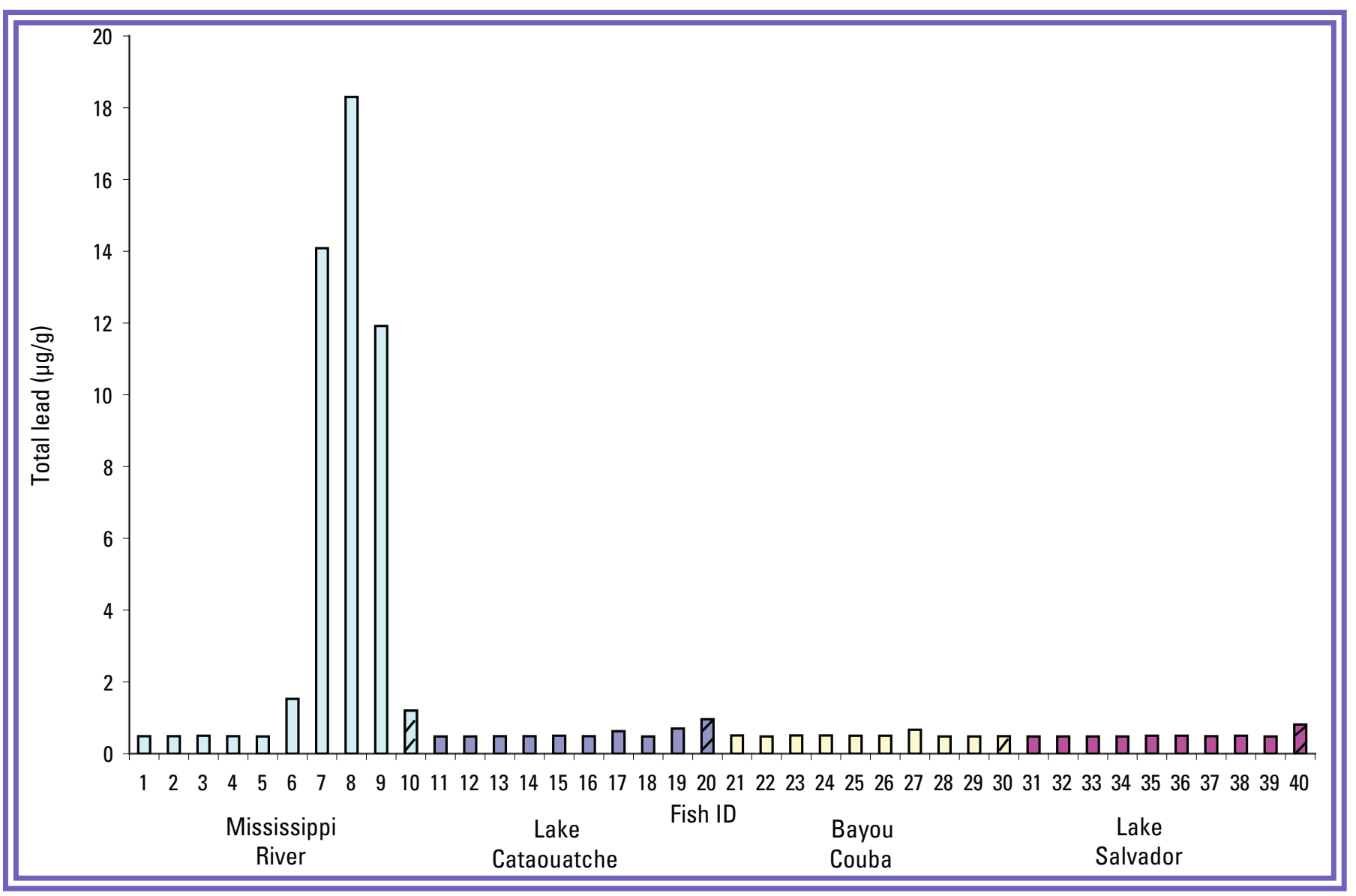

Figure 25. Lead from aquatic animal tissues collected from sites in southeastern Louisiana from January through June 2001. Lower limit of detection was 0.48 parts per million dry weight. Striped bars represent values for bivalves. Quality control of data checked by the U.S. Fish and Wildlife Service Analytical Control Facility.

\begin{tabular}{clcccccc}
\hline $\begin{array}{c}\text { Fish } \\
\text { ID }\end{array}$ & Sample ID & $\begin{array}{c}\text { Dry weight } \\
\text { concentration }\end{array}$ & $\begin{array}{c}\text { Wet weight } \\
\text { estimated }\end{array}$ & $\begin{array}{c}\text { Fish } \\
\text { ID }\end{array}$ & Sample ID & $\begin{array}{c}\text { Dry weight } \\
\text { concentration }\end{array}$ & $\begin{array}{c}\text { Wet weight } \\
\text { estimated }\end{array}$ \\
\hline 1 & LMB33RIVER & 0.49 & 0.14 & 21 & LMB10COUBA & 0.51 & 0.15 \\
2 & LMB34RIVER & 0.49 & 0.14 & 22 & LMB11COUBA & 0.48 & 0.14 \\
3 & LMB35RIVER & 0.5 & 0.15 & 23 & LMB3COUBA & 0.51 & 0.15 \\
4 & CAT38RIVER & 0.49 & 0.14 & 24 & CAT12COUBA & 0.51 & 0.15 \\
5 & CAT36RIVER & 0.48 & 0.14 & 25 & CAT13COUBA & 0.5 & 0.15 \\
6 & CAT37RIVER & 1.53 & 0.44 & 26 & CAT14COUBA & 0.5 & 0.15 \\
7 & MUL30RIVER & 14.09 & 4.09 & 27 & MUL26COUBA & 0.67 & 0.19 \\
8 & MUL31RIVER & 18.3 & 5.31 & 28 & MUL27COUBA & 0.48 & 0.14 \\
9 & MUL32RIVER & 11.92 & 3.46 & 29 & MUL28COUBA & 0.48 & 0.14 \\
10 & MUSSRIVER & 1.2 & 0.35 & 30 & MUSSCOUBA & 0.49 & 0.14 \\
11 & LMB21CATA & 0.48 & 0.14 & 31 & LMB4CAMP & 0.48 & 0.14 \\
12 & LMB24CATA & 0.48 & 0.14 & 32 & LMB5CAMP & 0.48 & 0.14 \\
13 & LMB25CATA & 0.49 & 0.14 & 33 & LMB6CAMP & 0.48 & 0.14 \\
14 & CAT22CATA & 0.485 & 0.14 & 34 & CAT1CAMP & 0.48 & 0.14 \\
15 & CAT23CATA & 0.5 & 0.15 & 35 & CAT2CAMP & 0.5 & 0.15 \\
16 & CAT7CATA & 0.49 & 0.14 & 36 & CAT3CAMP & 0.5 & 0.15 \\
17 & MUL18CATA & 0.63 & 0.18 & 37 & MUL15CAMP & 0.49 & 0.14 \\
18 & MUL19CATA & 0.48 & 0.14 & 38 & MUL16CAMP & 0.5 & 0.15 \\
19 & MUL20CATA & 0.7 & 0.20 & 39 & MUL17CAMP & 0.48 & 0.14 \\
20 & MUSSCATA & 0.96 & 0.28 & 40 & MUSSCAMP & 0.81 & 0.23 \\
\hline
\end{tabular}




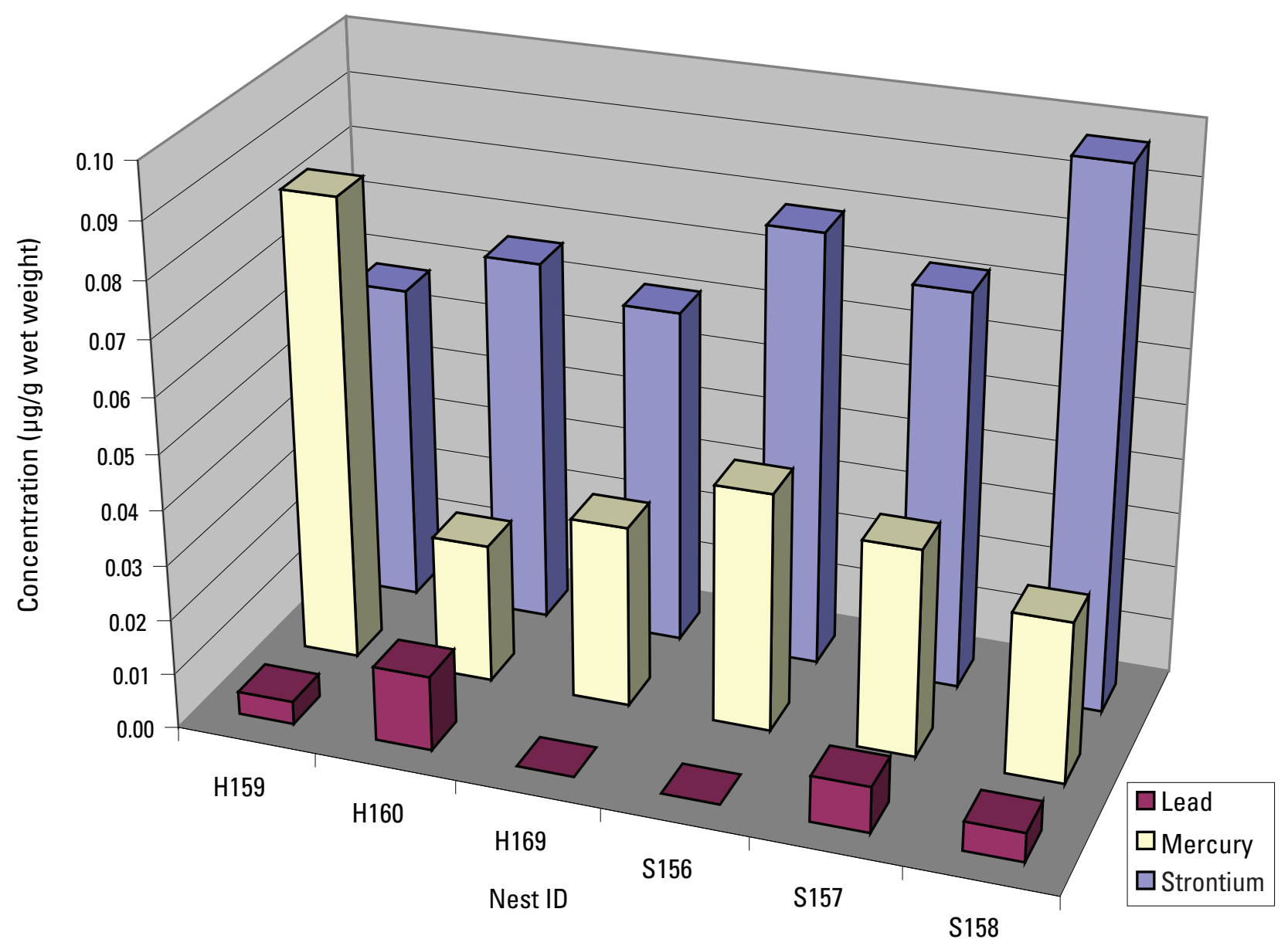

Figure 26. Concentrations of lead, mercury, and strontium from eaglet whole blood collected in southeastern Louisiana from January through June 2001.

$1.259 \mu \mathrm{g} / \mathrm{g} \mathrm{dw}(0.36 \mu \mathrm{g} / \mathrm{g}$ ww estimated $)$ and $0.608 \mu \mathrm{g} / \mathrm{g} \mathrm{dw}$ ( $0.17 \mu \mathrm{g} / \mathrm{g}$ ww estimated), respectively. In 1993, mercury concentrations from feathers of bald eagles from St. Mary Parish in Louisiana exceeded geometric means by a factor of 2.7 (Conzelmann and Rabot, 1994). In eaglet blood in the current study, mercury levels ranged from $0.0294 \mu \mathrm{g} / \mathrm{g}$ ww in the reference site to $0.0845 \mu \mathrm{g} / \mathrm{g} \mathrm{ww}$ in the experimental site (fig. 26). These concentrations can be considered low levels.

In the current study, just over 19 percent of the fish had measurable, yet relatively low, nickel levels (up to 1.63 $\mu \mathrm{g} / \mathrm{g} \mathrm{dw} ; 0.49 \mu \mathrm{g} / \mathrm{g}$ ww estimated) (fig. 31 ). No detectable levels of nickel were found in eagles (table 7). All but two eaglet samples had detectable lead levels (table 7). In the Caernarvon prediversion studies (Conzelmann and others, 1996), the maximum levels in the Mississippi River and marsh fish were $6.23 \mu \mathrm{g} / \mathrm{g} \mathrm{dw}(1.81 \mu \mathrm{g} / \mathrm{g}$ ww estimated $)$ and $20.6 \mu \mathrm{g} / \mathrm{g} \mathrm{dw}(5.97 \mu \mathrm{g} / \mathrm{g}$ ww estimated), respectively. In the
Caernarvon postdiversion studies (Conzelmann and others, 1996), the maximum levels in the Mississippi River and marsh fish were $11.49 \mu \mathrm{g} / \mathrm{g} \mathrm{dw}(3.33 \mu \mathrm{g} / \mathrm{g}$ ww estimated) and 28.7 $\mu \mathrm{g} / \mathrm{g} \mathrm{dw}(8.32 \mu \mathrm{g} / \mathrm{g}$ ww estimated), respectively. In the EMAP study (table 6; Summers, 2001), the range of concentrations of nickel was $0.026-0.543 \mu \mathrm{g} / \mathrm{g}$ ww from fish composites in the diversion areas.

In the current study, selenium levels in whole blood of eaglets ranged from 0.33 to $0.56 \mu \mathrm{g} / \mathrm{g} \mathrm{dw}$ (fig. 22). In nature, birds may eat foods that contain several chemical forms of selenium, and little is known about its ability to transfer to eggs, where embryos are most sensitive. In shorebirds, excessive amounts (7-10 $\mu \mathrm{g} / \mathrm{g} \mathrm{dw})$ of selenium in the diet has decreased egg hatchability, caused embryonic abnormalities, and reduced growth and survival of young (Williams and others, 1989). In adult birds, concentrations above $3 \mu \mathrm{g} / \mathrm{g}$ ww in the livers of laying females may be associated with 


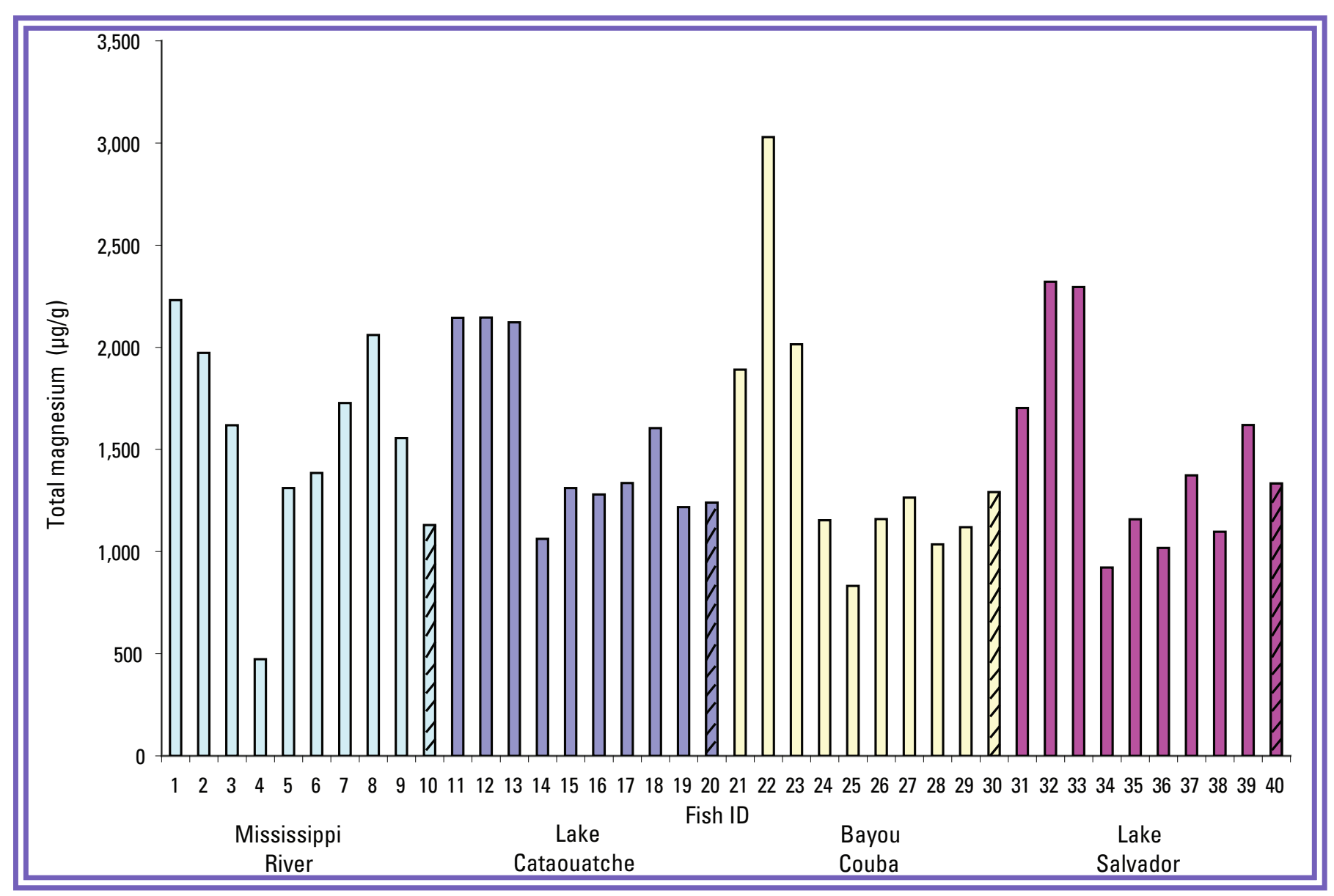

Figure 27. Magnesium
from aquatic animal
tissues collected from
sites in southeastern
Louisiana from January
through June 2001.
Lower limit of detection
was 4.81 parts per
million dry weight.
Striped bars represent
values for bivalves.
Quality control of data
checked by the U.S. Fish
and Wildlife Service
Analytical Control
Facility.

\begin{tabular}{lccclcc}
\hline Sample ID & $\begin{array}{c}\text { Dry weight } \\
\text { concentration }\end{array}$ & $\begin{array}{c}\text { Wet weight } \\
\text { estimated }\end{array}$ & $\begin{array}{c}\text { Fish } \\
\text { ID }\end{array}$ & Sample ID & $\begin{array}{c}\text { Dry weight } \\
\text { concentration }\end{array}$ & $\begin{array}{c}\text { Wet weight } \\
\text { estimated }\end{array}$ \\
\hline LMB33RIVER & $2,230.72$ & 646.91 & 21 & LMB10COUBA & $1,890.48$ & 548.24 \\
LMB34RIVER & $1,972.15$ & 571.92 & 22 & LMB11COUBA & $3,028.62$ & 878.30 \\
LMB35RIVER & $1,618.82$ & 469.46 & 23 & LMB3COUBA & $2,014.38$ & 584.17 \\
CAT38RIVER & 472.72 & 137.09 & 24 & CAT12COUBA & $1,152.95$ & 334.36 \\
CAT36RIVER & $1,311.30$ & 380.28 & 25 & CAT13COUBA & 832.55 & 241.44 \\
CAT37RIVER & $1,384.96$ & 401.64 & 26 & CAT14COUBA & $1,159.34$ & 336.21 \\
MUL30RIVER & $1,727.72$ & 501.04 & 27 & MUL26COUB & $1,264.15$ & 366.60 \\
MUL31RIVER & $2,060.48$ & 597.54 & 28 & MUL27COUBA & $1,035.48$ & 300.29 \\
MUL32RIVER & $1,555.40$ & 451.07 & 29 & MUL28COUBA & $1,119.97$ & 324.79 \\
MUSSRIVER & 1,130 & 327.70 & 30 & MUSSCOUBA & $1,291.82$ & 374.63 \\
LMB21CATA & $2,144.47$ & 621.90 & 31 & LMB4CAMP & $1,702.50$ & 493.73 \\
LMB24CATA & $2,145.02$ & 622.06 & 32 & LMB5CAMP & $2,321.16$ & 673.14 \\
LMB25CATA & $2,122.04$ & 615.39 & 33 & LMB6CAMP & $2,294.95$ & 665.54 \\
CAT22CATAE & $1,062.30$ & 308.07 & 34 & CAT1CAMP & 922.03 & 267.39 \\
CAT23CATA & $1,310.80$ & 380.13 & 35 & CAT2CAMP & $1,158.14$ & 335.86 \\
CAT7CATA & $1,280.03$ & 371.21 & 36 & CAT3CAMP & $1,017.74$ & 295.14 \\
MUL18CATA & $1,335.95$ & 387.43 & 37 & MUL15CAMP & $1,373.34$ & 398.27 \\
MUL19CATA & $1,604.10$ & 465.19 & 38 & MUL16CAMP & $1,097.36$ & 318.23 \\
MUL20CATA & $1,218.24$ & 353.29 & 39 & MUL17CAMP & $1,619.52$ & 469.66 \\
MUSSCATA & $1,239.51$ & 359.46 & 40 & MUSSCAMP & $1,333.04$ & 386.58 \\
\hline
\end{tabular}




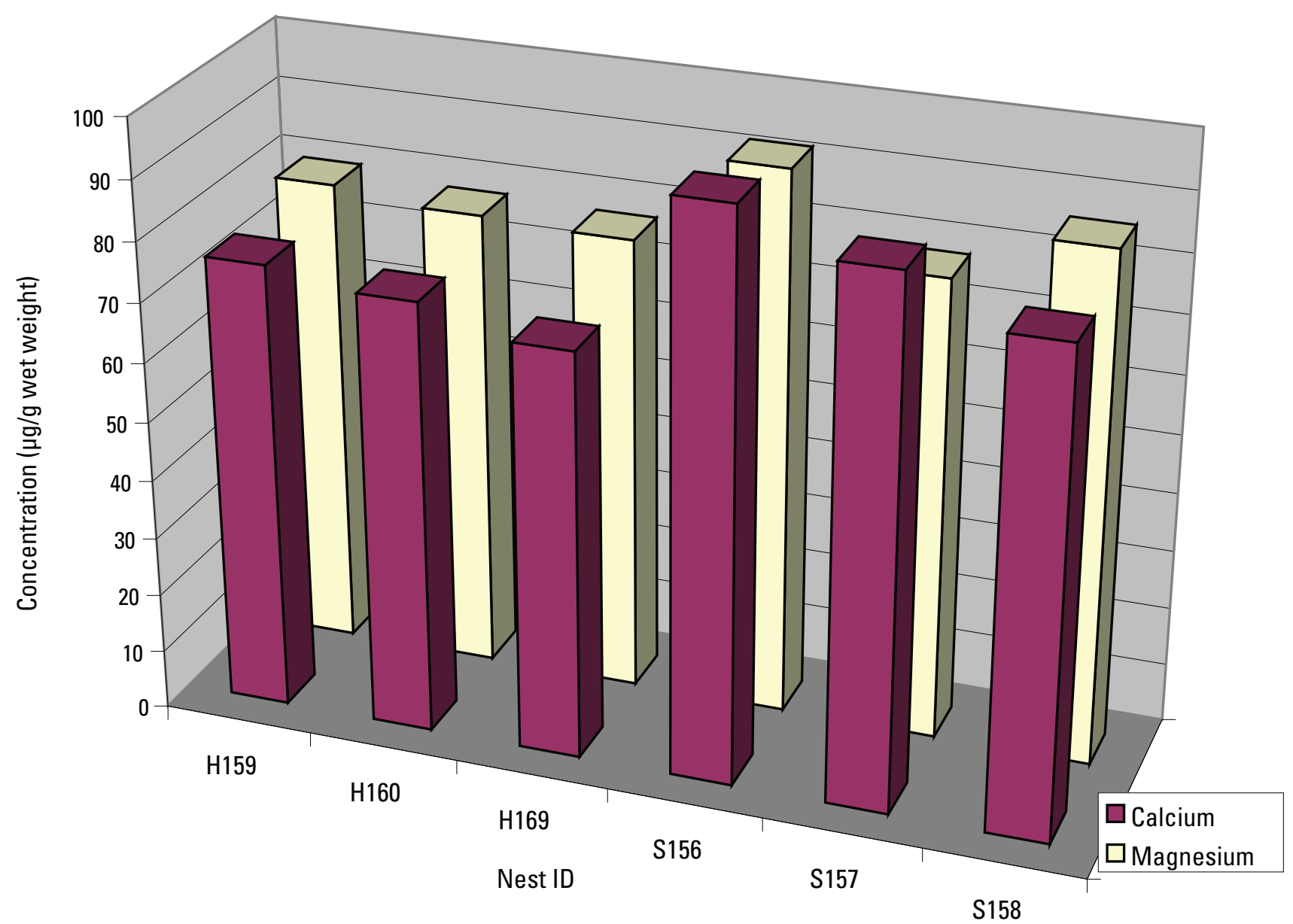

Figure 28. Concentrations of calcium and magnesium ( $\mu \mathrm{g} / \mathrm{g}$ wet weight) from eaglet whole blood collected in southeastern Louisiana from January through June 2001.

reproductive impairment, and blood samples are only sometimes comparable (Heinz, 1996). Dead mallards (Anas platyrhynchos) were seen with blood levels between 5 and 14 ppm ww selenium (Heinz, 1996).

In the current study, selenium levels in fish were generally higher than the average values found in the 1995-96 BEST study (Schmitt, 2002). Ranked geometric means from the BEST results (1995-96) ranged from about 0.20 to $1.25 \mu \mathrm{g} / \mathrm{g}$ ww in composite fish samples, with one station showing an outlying high at nearly $4 \mathrm{ppm}$. The 85th percentile for selenium from the NCBP (table 1) (Schmitt and Brumbaugh, 1990) was $0.73 \mu \mathrm{g} / \mathrm{g}$ ww. In this study, approximately 86 percent of the fish had measurable selenium levels (fig. 32), yet none reached the 85th percentile. Two of the four bivalve samples showed levels higher than the 85 th percentile, and two largemouth bass from the Mississippi River approached the 85th percentile. In the Caernarvon prediversion studies (Conzelmann and others, 1996), the maximum levels in Mississippi River and marsh fish were $3.47 \mu \mathrm{g} / \mathrm{g} \mathrm{dw}(0.90 \mu \mathrm{g} / \mathrm{g}$ ww) and $2.54 \mu \mathrm{g} / \mathrm{g} \mathrm{dw}(0.58 \mu \mathrm{g} / \mathrm{g} \mathrm{ww})$, respectively. In the Caernarvon postdiversion studies (Conzelmann and others, 1996), the maximum levels in the Mississippi River and marsh fish were $5.34 \mu \mathrm{g} / \mathrm{g} \mathrm{dw}(1.11 \mu \mathrm{g} / \mathrm{g} \mathrm{ww})$ and $3.54 \mu \mathrm{g} / \mathrm{g} \mathrm{dw}$ $(0.69 \mu \mathrm{g} / \mathrm{g} \mathrm{ww})$, respectively. In the EMAP study (table 6; Summers, 2001), the range of concentrations of selenium was $0.021-0.335 \mu \mathrm{g} / \mathrm{g}$ ww from fish composites in the diversion areas.

Strontium is considered nontoxic in hydrologic environments (Meade, 1995). As in the Caernarvon prediversion study (Conzelmann and others, 1996), in the 


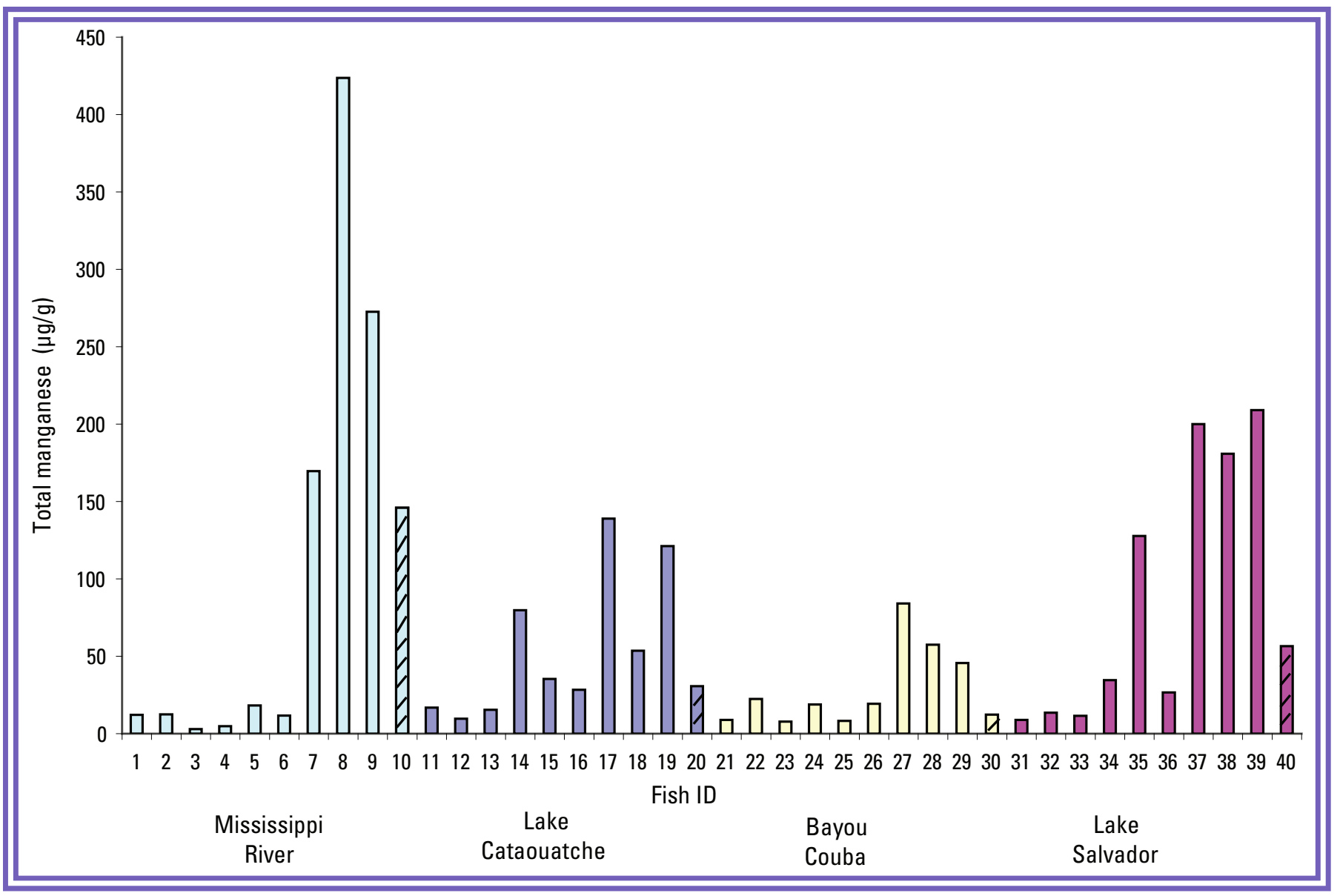

Figure 29. Manganese
from aquatic animal
tissues collected from
sites in southeastern
Louisiana from
January through
June 2001. Lower
limit of detection
was 0.96 parts per
million dry weight.
Striped bars represent
values for bivalves.
Quality control of
data checked by the
U.S. Fish and Wildlife
Service Analytical
Control Facility.

\begin{tabular}{clcrrrrr}
\hline $\begin{array}{c}\text { Fish } \\
\text { ID }\end{array}$ & Sample ID & $\begin{array}{c}\text { Dry weight } \\
\text { concentration }\end{array}$ & $\begin{array}{c}\text { Wet weight } \\
\text { estimated }\end{array}$ & $\begin{array}{c}\text { Fish } \\
\text { ID }\end{array}$ & Sample ID & $\begin{array}{c}\text { Dry weight } \\
\text { concentration }\end{array}$ & $\begin{array}{c}\text { Wet weight } \\
\text { estimated }\end{array}$ \\
\hline 1 & LMB33RIVER & 12.22 & 3.54 & 21 & LMB10COUBA & 8.94 & 2.59 \\
2 & LMB34RIVER & 12.45 & 3.61 & 22 & LMB11COUBA & 22.45 & 6.51 \\
3 & LMB35RIVER & 3.03 & 0.88 & 23 & LMB3COUBA & 7.86 & 2.28 \\
4 & CAT38RIVER & 4.81 & 1.39 & 24 & CAT12COUBA & 18.8 & 5.45 \\
5 & CAT36RIVER & 18.23 & 5.29 & 25 & CAT13COUBA & 8.33 & 2.42 \\
6 & CAT37RIVER & 11.7 & 3.39 & 26 & CAT14COUBA & 19.38 & 5.62 \\
7 & MUL30RIVER & 169.6 & 49.18 & 27 & MUL26COUBA & 84.09 & 24.39 \\
8 & MUL31RIVER & 423.64 & 122.86 & 28 & MUL27COUBA & 57.44 & 16.66 \\
9 & MUL32RIVER & 272.56 & 79.04 & 29 & MUL28COUBA & 45.66 & 13.24 \\
10 & MUSSRIVER & 146 & 42.34 & 30 & MUSSCOUBA & 12.36 & 3.58 \\
11 & LMB21CATA & 16.81 & 4.87 & 31 & LMB4CAMP & 8.81 & 2.55 \\
12 & LMB24CATA & 9.64 & 2.80 & 32 & LMB5CAMP & 13.59 & 3.94 \\
13 & LMB25CATA & 15.38 & 4.46 & 33 & LMB6CAMP & 11.49 & 3.33 \\
14 & CAT22CATA & 79.735 & 23.12 & 34 & CAT1CAMP & 34.52 & 10.01 \\
15 & CAT23CATA & 35.42 & 10.27 & 35 & CAT2CAMP & 127.73 & 37.04 \\
16 & CAT7CATA & 28.34 & 8.22 & 36 & CAT3CAMP & 26.68 & 7.74 \\
17 & MUL18CATA & 139 & 40.31 & 37 & MUL15CAMP & 200.06 & 58.02 \\
18 & MUL19CATA & 53.59 & 15.54 & 38 & MUL16CAMP & 180.78 & 52.43 \\
19 & MUL20CATA & 121.24 & 35.16 & 39 & MUL17CAMP & 209.04 & 60.62 \\
20 & MUSSCATA & 30.66 & 8.89 & 40 & MUSSCAMP & 56.51 & 16.39 \\
\hline
\end{tabular}




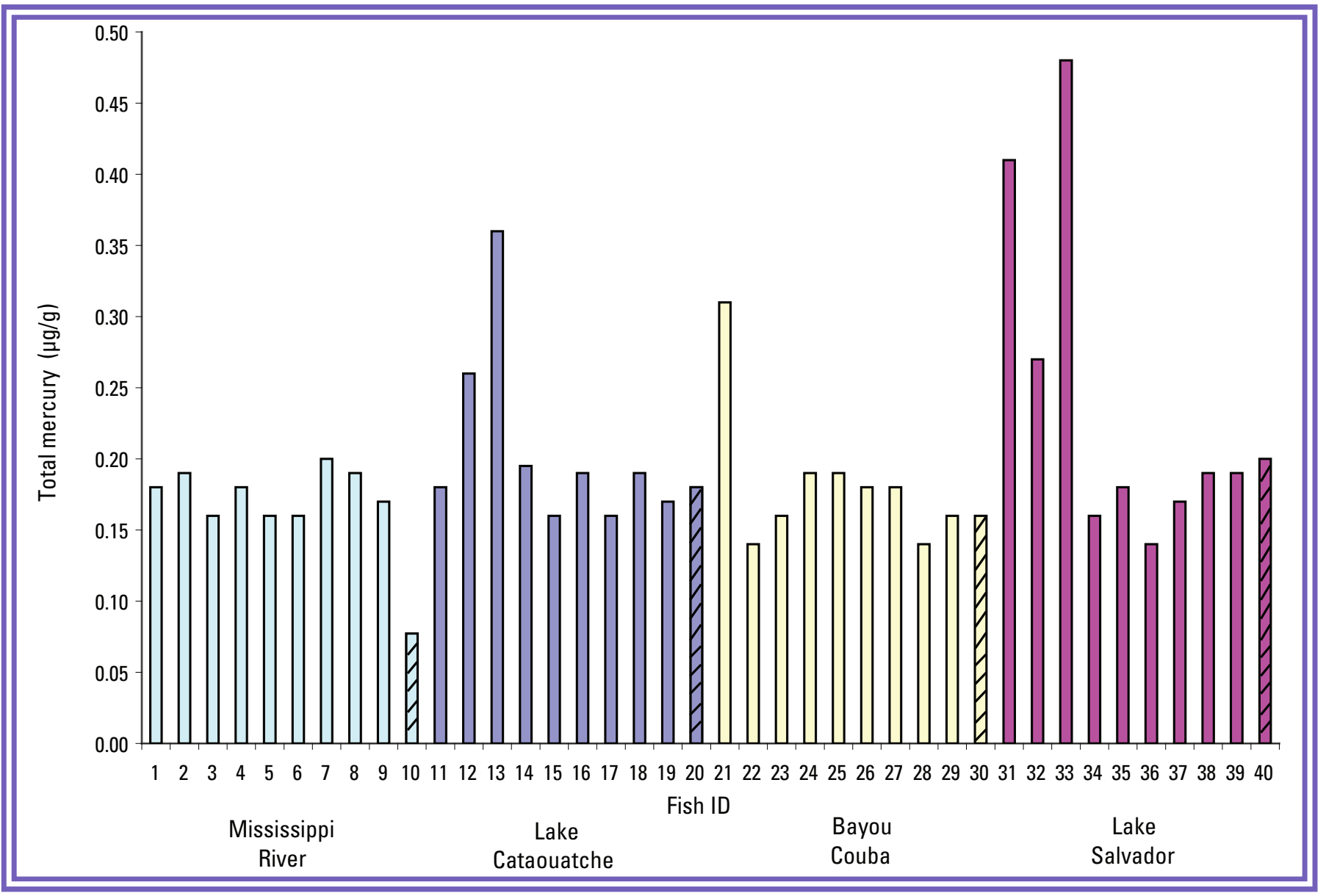

Figure 30. Mercury from aquatic animal tissues collected from sites in southeastern Louisiana from January through June 2001. Lower limit of detection was 0.16 parts per million dry weight. Striped bars represent values for bivalves. Quality control of data checked by the U.S. Fish and Wildlife Service Analytical Control Facility.

\begin{tabular}{clcccccc}
\hline $\begin{array}{c}\text { Fish } \\
\text { ID }\end{array}$ & Sample ID & $\begin{array}{c}\text { Dry weight } \\
\text { concentration }\end{array}$ & $\begin{array}{c}\text { Wet weight } \\
\text { estimated }\end{array}$ & $\begin{array}{c}\text { Fish } \\
\text { ID }\end{array}$ & Sample ID & $\begin{array}{c}\text { Dry weight } \\
\text { concentration }\end{array}$ & $\begin{array}{c}\text { Wet weight } \\
\text { estimated }\end{array}$ \\
\hline 1 & LMB33RIVER & 0.18 & 0.05 & 21 & LMB10COUBA & 0.31 & 0.09 \\
2 & LMB34RIVER & 0.19 & 0.06 & 22 & LMB11COUBA & 0.14 & 0.04 \\
3 & LMB35RIVER & 0.16 & 0.05 & 23 & LMB3COUBA & 0.16 & 0.05 \\
4 & CAT38RIVER & 0.18 & 0.05 & 24 & CAT12COUBA & 0.19 & 0.06 \\
5 & CAT36RIVER & 0.16 & 0.05 & 25 & CAT13COUBA & 0.19 & 0.06 \\
6 & CAT37RIVER & 0.16 & 0.05 & 26 & CAT14COUBA & 0.18 & 0.05 \\
7 & MUL30RIVER & 0.2 & 0.06 & 27 & MUL26COUBA & 0.18 & 0.05 \\
8 & MUL31RIVER & 0.19 & 0.06 & 28 & MUL27COUBA & 0.14 & 0.04 \\
9 & MUL32RIVER & 0.17 & 0.05 & 29 & MUL28COUBA & 0.16 & 0.05 \\
10 & MUSSRIVER & 0.077 & 0.02 & 30 & MUSSCOUBA & 0.16 & 0.05 \\
11 & LMB21CATA & 0.18 & 0.05 & 31 & LMB4CAMP & 0.41 & 0.12 \\
12 & LMB24CATA & 0.26 & 0.08 & 32 & LMB5CAMP & 0.27 & 0.08 \\
13 & LMB25CATA & 0.36 & 0.10 & 33 & LMB6CAMP & 0.48 & 0.14 \\
14 & CAT22CATA & 0.195 & 0.06 & 34 & CAT1CAMP & 0.16 & 0.05 \\
15 & CAT23CATA & 0.16 & 0.05 & 35 & CAT2CAMP & 0.18 & 0.05 \\
16 & CAT7CATA & 0.19 & 0.06 & 36 & CAT3CAMP & 0.14 & 0.04 \\
17 & MUL18CATA & 0.16 & 0.05 & 37 & MUL15CAMP & 0.17 & 0.05 \\
18 & MUL19CATA & 0.19 & 0.06 & 38 & MUL16CAMP & 0.19 & 0.06 \\
19 & MUL20CATA & 0.17 & 0.05 & 39 & MUL17CAMP & 0.19 & 0.06 \\
20 & MUSSCATA & 0.18 & 0.05 & 40 & MUSSCAMP & 0.2 & 0.06 \\
\hline
\end{tabular}




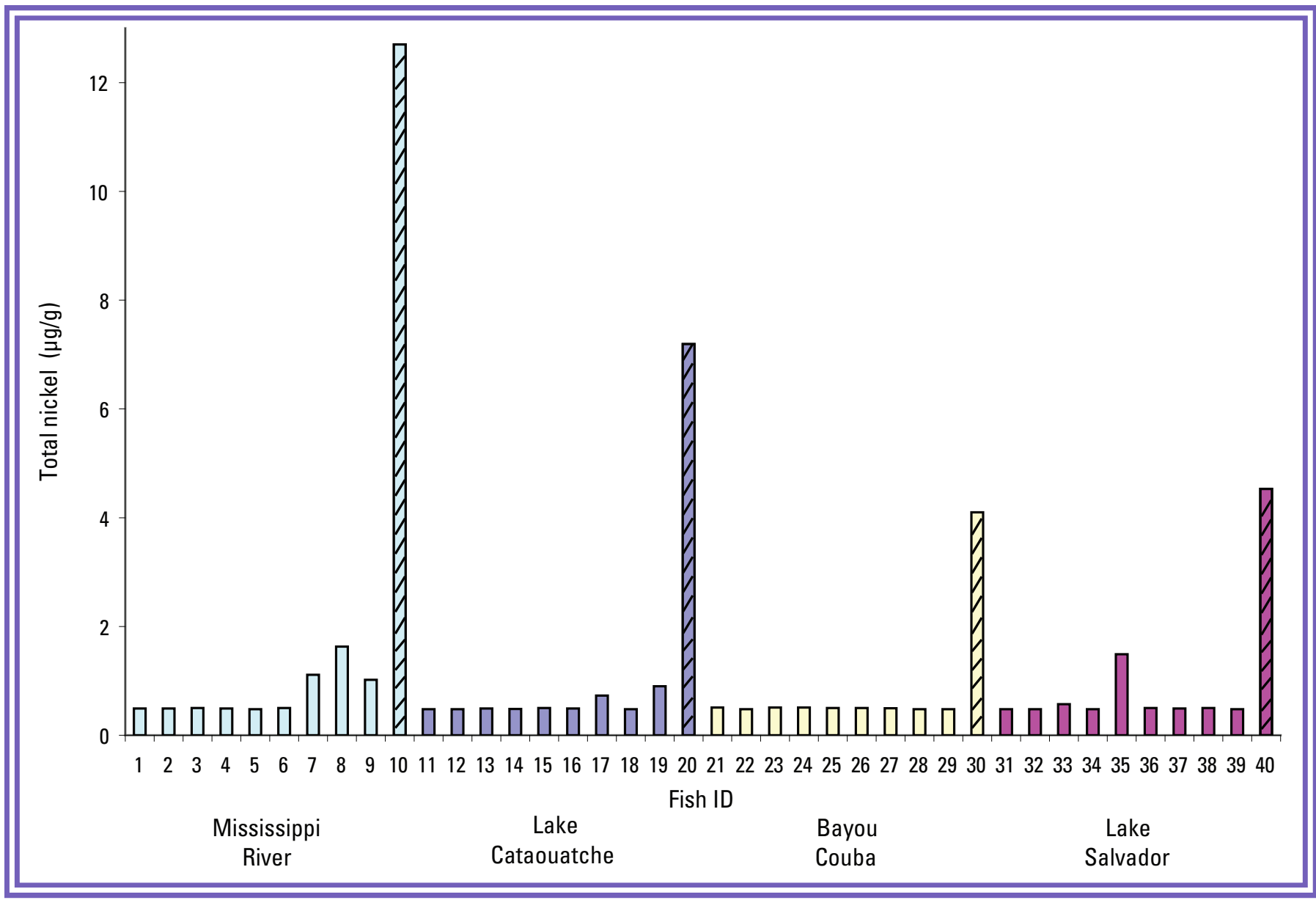

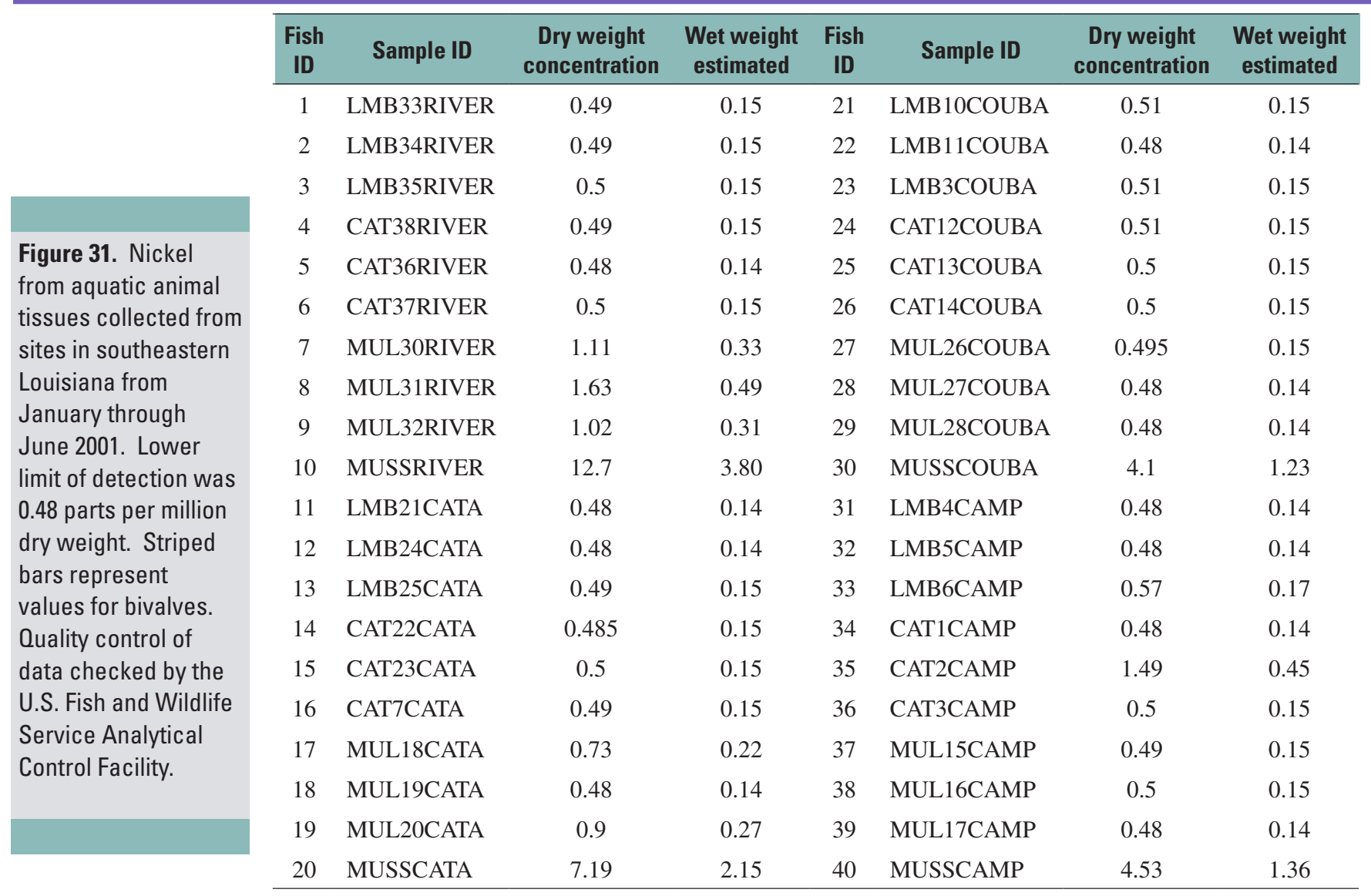




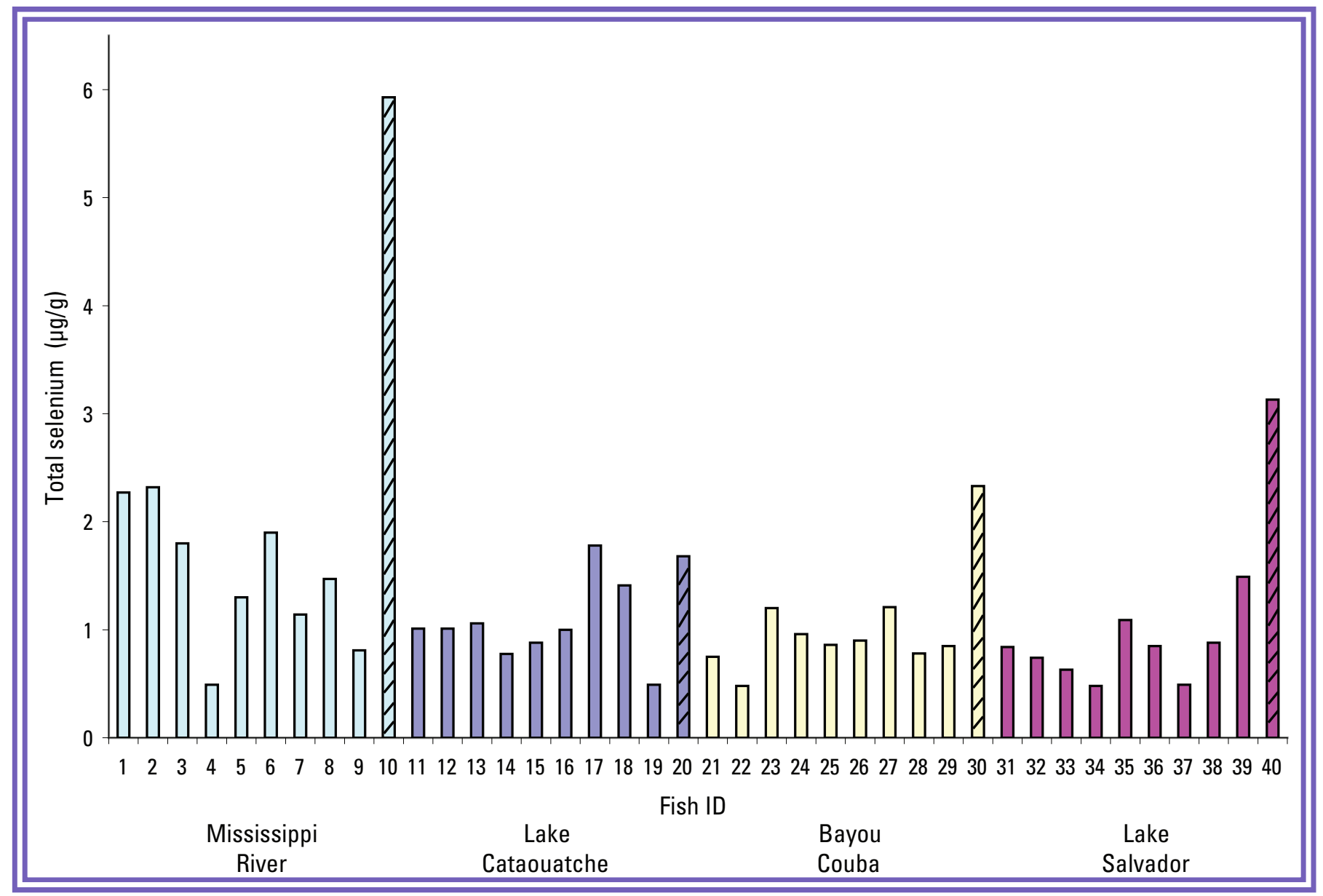

Figure 32. Selenium from aquatic animal tissues collected from sites in southeastern Louisiana from January through June 2001. Lower limit of detection was 0.48 parts per million dry weight. Striped bars represent values for bivalves. Quality control of data checked by the U.S. Fish and Wildlife Service Analytical Control Facility.

\begin{tabular}{clcccccc}
\hline $\begin{array}{c}\text { Fish } \\
\text { ID }\end{array}$ & Sample ID & $\begin{array}{c}\text { Dry weight } \\
\text { concentration }\end{array}$ & $\begin{array}{c}\text { Wet weight } \\
\text { estimated }\end{array}$ & $\begin{array}{c}\text { Fish } \\
\text { ID }\end{array}$ & Sample ID & $\begin{array}{c}\text { Dry weight } \\
\text { concentration }\end{array}$ & $\begin{array}{c}\text { Wet weight } \\
\text { estimated }\end{array}$ \\
\hline 1 & LMB33RIVER & 2.27 & 0.68 & 21 & LMB10COUBA & 0.75 & 0.22 \\
2 & LMB34RIVER & 2.32 & 0.69 & 22 & LMB11COUBA & 0.48 & 0.14 \\
3 & LMB35RIVER & 1.8 & 0.54 & 23 & LMB3COUBA & 1.2 & 0.36 \\
4 & CAT38RIVER & 0.49 & 0.15 & 24 & CAT12COUBA & 0.96 & 0.29 \\
5 & CAT36RIVER & 1.3 & 0.39 & 25 & CAT13COUBA & 0.86 & 0.26 \\
6 & CAT37RIVER & 1.9 & 0.57 & 26 & CAT14COUBA & 0.9 & 0.27 \\
7 & MUL30RIVER & 1.14 & 0.34 & 27 & MUL26COUBA & 1.21 & 0.36 \\
8 & MUL31RIVER & 1.47 & 0.44 & 28 & MUL27COUBA & 0.78 & 0.23 \\
9 & MUL32RIVER & 0.81 & 0.24 & 29 & MUL28COUBA & 0.85 & 0.25 \\
10 & MUSSRIVER & 5.93 & 1.78 & 30 & MUSSCOUBA & 2.33 & 0.70 \\
11 & LMB21CATA & 1.01 & 0.30 & 31 & LMB4CAMP & 0.84 & 0.25 \\
12 & LMB24CATA & 1.01 & 0.30 & 32 & LMB5CAMP & 0.74 & 0.22 \\
13 & LMB25CATA & 1.06 & 0.32 & 33 & LMB6CAMP & 0.63 & 0.19 \\
14 & CAT22CATA & 0.78 & 0.23 & 34 & CAT1CAMP & 0.48 & 0.14 \\
15 & CAT23CATA & 0.88 & 0.26 & 35 & CAT2CAMP & 1.09 & 0.33 \\
16 & CAT7CATA & 1.00 & 0.30 & 36 & CAT3CAMP & 0.85 & 0.25 \\
17 & MUL18CATA & 1.78 & 0.53 & 37 & MUL15CAMP & 0.49 & 0.15 \\
18 & MUL19CATA & 1.41 & 0.42 & 38 & MUL16CAMP & 0.88 & 0.26 \\
19 & MUL20CATA & 0.49 & 0.15 & 39 & MUL17CAMP & 1.49 & 0.45 \\
20 & MUSSCATA & 1.68 & 0.50 & 40 & MUSSCAMP & 3.13 & 0.94 \\
\hline
\end{tabular}


current study higher levels of strontium were seen in marsh sites (fig. 33). Catfish in Bayou Couba showed higher levels of chromium $(P=0.0015)$ and strontium $(P=0.0 .0074)$ than did mullet, yet they showed the lowest levels of copper $(P=$ 0.0065). According to NOAA SQuiRTs (Buchman, 2003), a background level of strontium in freshwater sediment is 49 $\mu \mathrm{g} / \mathrm{g} \mathrm{dw}$. In the current study, strontium levels in eaglet blood ranged from 0.0581 to $0.0975 \mu \mathrm{g} / \mathrm{g} \mathrm{dw}$ (fig. 26).

Vanadium is considered to be moderate to highly toxic in hydrologic environments (Meade, 1995). Levels of vanadium $(P=0.0156)$ in mullet were significantly higher in the Mississippi River than in Lake Cataouatche and Bayou Couba and higher than in the other two fish species (fig. 34). According to the NOAA SQuiRTs (Buchman, 2003), a background level of vanadium in freshwater sediment is 50 $\mu \mathrm{g} / \mathrm{g}$ dw. No detectable levels of vanadium were found in eaglet blood in the current study.

In the current study, one fish (MUL31RIVER, fish ID 8) showed levels of zinc at $125.4 \mu \mathrm{g} / \mathrm{g} \mathrm{dw}(37.54 \mu \mathrm{g} / \mathrm{g} \mathrm{ww}$ estimated) (fig. 35), being higher than the 85th percentile (Schmitt and Brumbaugh, 1990) (table 1). The NCBP program lists the 85th percentile for zinc at $34.2 \mu \mathrm{g} / \mathrm{g} \mathrm{fw}$ (117.9 $\mu \mathrm{g} / \mathrm{g} \mathrm{dw}$ ) (table 1). The Mississippi River bivalve sample had a level of $140 \mu \mathrm{g} / \mathrm{g} \mathrm{dw}(41.2 \mu \mathrm{g} / \mathrm{g}$ ww estimated). In the 1995-96 BEST study (Schmitt, 2002), the zinc concentration ranged from 40 to $150 \mu \mathrm{g} / \mathrm{g}$ ww in common carp (Cyprinus carpio) and was at lower levels in the other species. In the Caernarvon prediversion studies, the maximum zinc levels in Mississippi River and marsh fish were $74.7 \mu \mathrm{g} / \mathrm{g} \mathrm{dw}$ (20.1 $\mu \mathrm{g} / \mathrm{g} \mathrm{ww})$ and $97.1 \mu \mathrm{g} / \mathrm{g} \mathrm{dw}(27.0 \mu \mathrm{g} / \mathrm{g} \mathrm{ww})$, respectively. In the Caernarvon postdiversion studies, the maximum levels of zinc in Mississippi River and marsh fish were $92.8 \mu \mathrm{g} / \mathrm{g} \mathrm{dw}$ (16.7 $\mu \mathrm{g} / \mathrm{g} \mathrm{ww})$ and $83.7 \mu \mathrm{g} / \mathrm{g} \mathrm{dw}(31.4 \mu \mathrm{g} / \mathrm{g} \mathrm{ww})$, respectively. In the EMAP study (table 6; Summers, 2001), the range of concentrations of zinc was 2.93-13.03 $\mu \mathrm{g} / \mathrm{g}$ fw from fish composites in the Davis Pond area. In the current study, levels of zinc in eaglet blood ranged up to $6.8 \mu \mathrm{g} / \mathrm{g}$ ww (fig. 14).

The trace element ranges detected in fish and bivalves from the prediversion studies at Caernarvon (1990-91) and Davis Pond (2001) are presented in table 8.

Eaglets from each nest appeared healthy and in good condition except for one smaller eaglet in nest H160 (table 9). This eaglet, appearing 2 weeks younger than the other, had an injured right eye area that displayed infection. The injury appeared to be the result of an aggressive attack by the sibling. The injured eaglet was not banded, nor was a blood sample collected.

Nests sampled were those having a minimum of 5 years of past activity recorded (app. 1, table 1-4). Success for nests in the pond area (nests S156, S157, S158) and reference area (nests H169, H160, H159) was similar. When temperatures were below average during the winter of 2000 and there were drought conditions (climate data from NOAA National Weather Service), nests in both regions similarly failed.

\section{Discussion}

The coastal wetlands of Louisiana are of great national importance: they are one of the most valuable and productive habitats for fish and wildlife in North America. Loss of coastal wetlands is a complex process, and river diversion projects designed to restore lost wetlands are just beginning to show the potential risks of river-borne anthropogenic compounds. Diversions of Mississippi River water into Louisiana's coastal wetlands have been recommended to be "buffered" by wetland overland flow before it reaches larger lakes and bays, where conditions for hypoxic events may be present (Lane and others, 2001). The release of Mississippi River water introduces sediments, nutrients, and accompanying point and nonpoint source compounds into the receiving marshes. The Mississippi River and its tributaries carry runoff from agricultural lands and industrial effluents from extensive areas of the United States and some of Canada. The water quality of the lower Mississippi River is also affected by the New Orleans-Baton Rouge industrial corridor (the area along the river between the two cities). Highest flows in the river occur from February through May, whereas lowest flows generally occur during September through October. Long durations of low flow periods increase saltwater intrusion from the Gulf of Mexico.

Wildlife can be exposed to environmental contaminants through inhalation, dermal contact, or ingestion. For wildlife exposure assessments, screens are often performed for potentially significant exposures to estimate contaminant intakes or doses by significant routes of exposure. Animal representatives at different levels of the food chain can differentially concentrate elements (Guthrie and Cherry, 1979). Fish are often selected for monitoring aquatic ecosystems because they accumulate pesticides and other contaminants (Schmitt and Bunck, 1995). In aquatic ecosystems, fish represent higher order biota and thus constitute a high state of the biomagnification process of chemical pesticides (Roche and others, 2000); however, some chemicals are accumulated, while others are metabolized. A number of biotransformations and metabolic processes act to reduce contaminant levels. Generally, toxicity of compounds to fish depends on the size of the fish, the form of the compounds, overall water quality, the concentration of the compound, and exposure time. Synergistic, antagonistic, and additive effects can be expected under conditions in which levels of several elements are elevated (Sorenson, 1991). The toxicology of essential elements - such as copper, zinc, and selenium - is more complicated than that of nonessential elements such as mercury. In biomonitoring studies, atypically high concentrations would indicate potential ecotoxicological effects.

The environments to which animals are exposed represent those parts of a habitat that are functionally significant during all or part of an organism's life. In the current study, levels of compounds were determined from whole bodies of three 


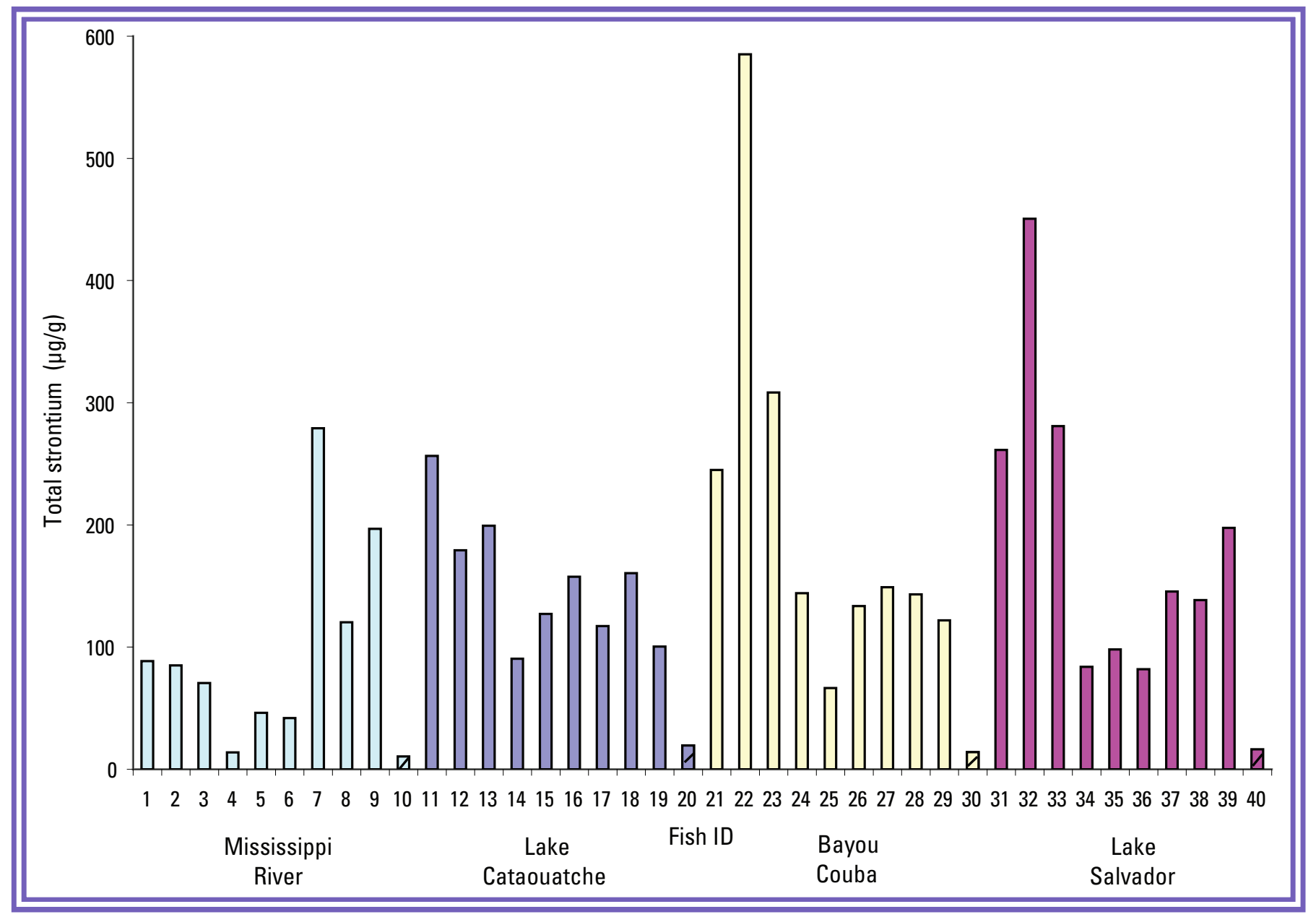

Figure 33. Strontium from aquatic animal tissues collected from sites in southeastern Louisiana from January through June 2001. Lower limit of detection was 0.48 parts per million dry weight. Striped bars represent values for bivalves. Quality control of data checked by the U.S. Fish and Wildlife Service Analytical Control Facility.

\begin{tabular}{clcccccc}
\hline $\begin{array}{c}\text { Fish } \\
\text { ID }\end{array}$ & Sample ID & $\begin{array}{c}\text { Dry weight } \\
\text { concentration }\end{array}$ & $\begin{array}{c}\text { Wet weight } \\
\text { estimated }\end{array}$ & $\begin{array}{c}\text { Fish } \\
\text { ID }\end{array}$ & Sample ID & $\begin{array}{c}\text { Dry weight } \\
\text { concentration }\end{array}$ & $\begin{array}{c}\text { Wet weight } \\
\text { estimated }\end{array}$ \\
\hline 1 & LMB33RIVER & 88.6 & 26.53 & 21 & LMB10COUBA & 245.09 & 73.38 \\
2 & LMB34RIVER & 84.95 & 25.43 & 22 & LMB11COUBA & 585.08 & 175.17 \\
3 & LMB35RIVER & 70.58 & 21.13 & 23 & LMB3COUBA & 308.32 & 92.31 \\
4 & CAT38RIVER & 13.81 & 4.13 & 24 & CAT12COUBA & 144.24 & 43.19 \\
5 & CAT36RIVER & 46.31 & 13.87 & 25 & CAT13COUBA & 66.54 & 19.92 \\
6 & CAT37RIVER & 41.96 & 12.56 & 26 & CAT14COUBA & 133.52 & 39.98 \\
7 & MUL30RIVER & 279.22 & 83.60 & 27 & MUL26COUBA & 149.095 & 44.64 \\
8 & MUL31RIVER & 120.32 & 36.02 & 28 & MUL27COUBA & 143.17 & 42.87 \\
9 & MUL32RIVER & 196.78 & 58.92 & 29 & MUL28COUBA & 121.94 & 36.51 \\
10 & MUSSRIVER & 10.6 & 3.17 & 30 & MUSSCOUBA & 14.14 & 4.23 \\
11 & LMB21CATA & 256.49 & 76.79 & 31 & LMB4CAMP & 261.32 & 78.24 \\
12 & LMB24CATA & 179.19 & 53.65 & 32 & LMB5CAMP & 450.53 & 134.89 \\
13 & LMB25CATA & 199.33 & 59.68 & 33 & LMB6CAMP & 280.98 & 84.13 \\
14 & CAT22CATA & 90.48 & 27.09 & 34 & CAT1CAMP & 83.82 & 25.10 \\
15 & CAT23CATA & 127.15 & 38.07 & 35 & CAT2CAMP & 98.16 & 29.39 \\
16 & CAT7CATA & 157.63 & 47.19 & 36 & CAT3CAMP & 81.83 & 24.50 \\
17 & MUL18CATA & 117.19 & 35.09 & 37 & MUL15CAMP & 145.44 & 43.54 \\
18 & MUL19CATA & 160.45 & 48.04 & 38 & MUL16CAMP & 138.43 & 41.45 \\
19 & MUL20CATA & 100.49 & 30.09 & 39 & MUL17CAMP & 197.63 & 59.17 \\
20 & MUSSCATA & 19.55 & 5.85 & 40 & MUSSCAMP & 16.44 & 4.92 \\
\hline & & & & & & \\
\hline
\end{tabular}




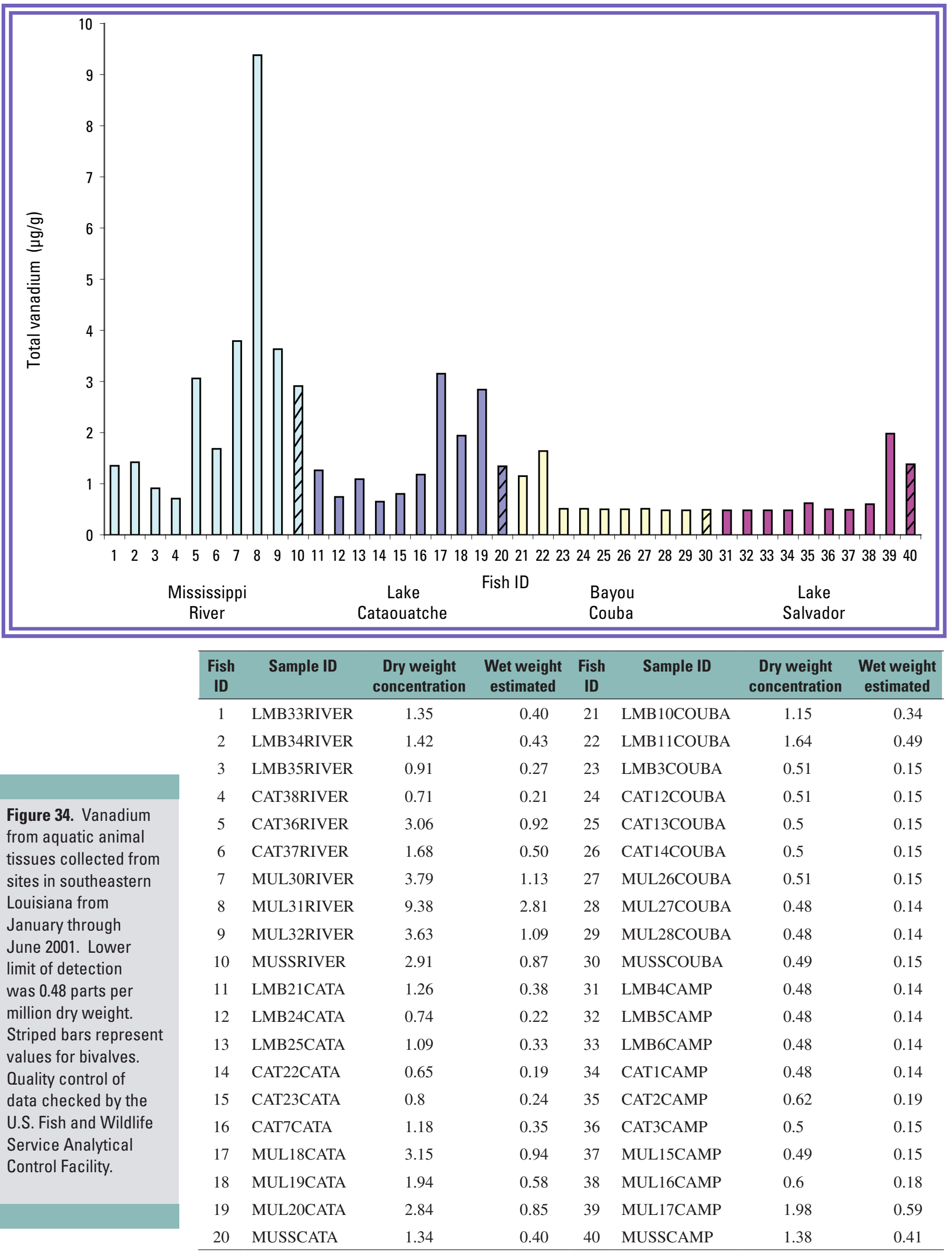




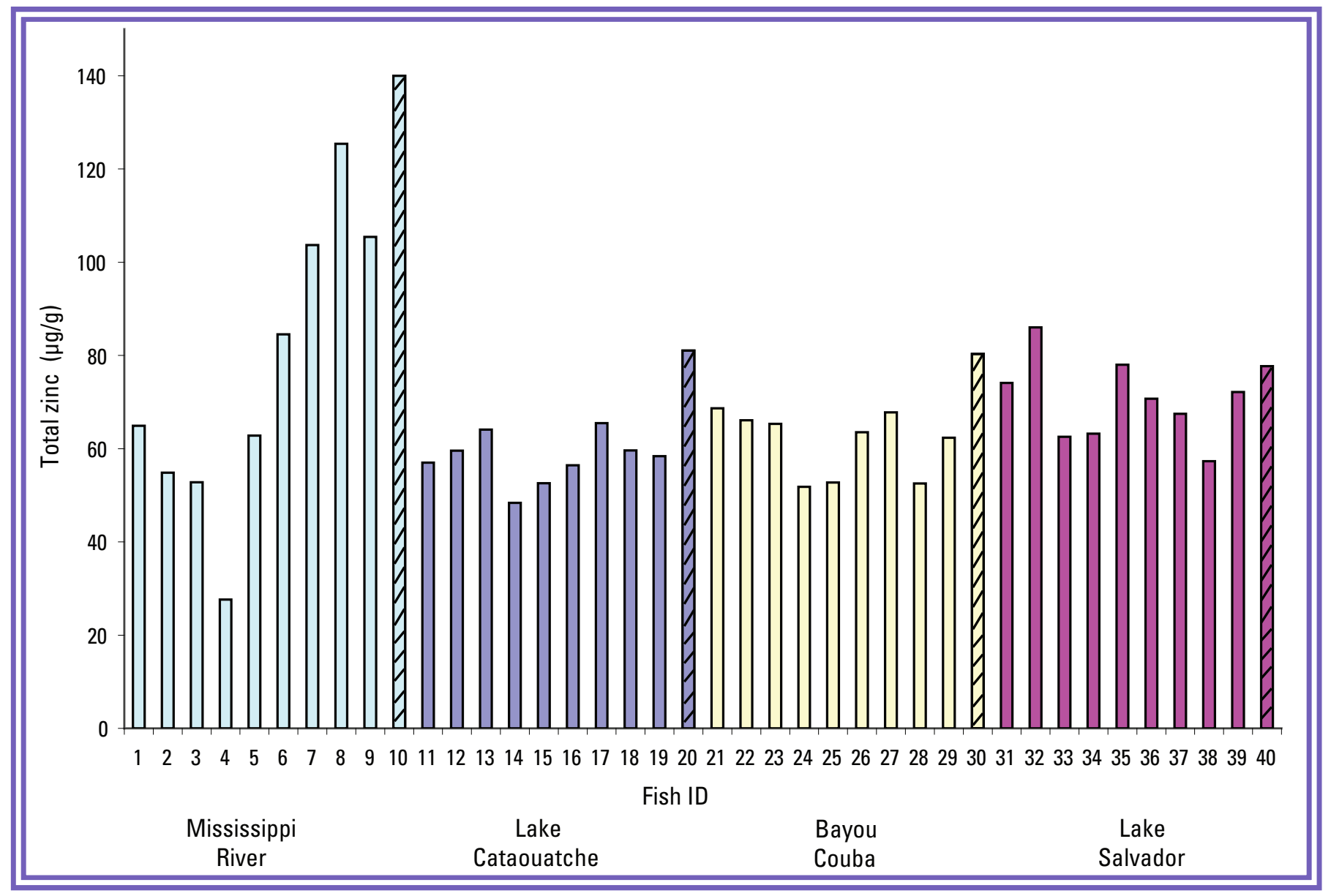

Figure 35. Zinc from aquatic animal tissues collected from sites in southeastern Louisiana from January through June 2001. Lower limit of detection was 1.01 parts per million dry weight. Striped bars represent values for bivalves. Quality control of data checked by the U.S. Fish and Wildlife Service Analytical Control Facility.

\begin{tabular}{|c|c|c|c|c|c|c|c|}
\hline $\begin{array}{l}\text { Fish } \\
\text { ID }\end{array}$ & Sample ID & $\begin{array}{l}\text { Dry weight } \\
\text { concentration }\end{array}$ & $\begin{array}{c}\text { Wet weight } \\
\text { estimated }\end{array}$ & $\begin{array}{l}\text { Fish } \\
\text { ID }\end{array}$ & Sample ID & $\begin{array}{l}\text { Dry weight } \\
\text { concentration }\end{array}$ & $\begin{array}{c}\text { Wet weight } \\
\text { estimated }\end{array}$ \\
\hline 1 & LMB33RIVER & 64.89 & 19.43 & 21 & LMB10COUBA & 68.67 & 20.56 \\
\hline 2 & LMB34RIVER & 54.85 & 16.42 & 22 & LMB11COUBA & 66.09 & 19.79 \\
\hline 3 & LMB35RIVER & 52.81 & 15.81 & 23 & LMB3COUBA & 65.34 & 19.56 \\
\hline 4 & CAT38RIVER & 27.63 & 8.27 & 24 & CAT12COUBA & 51.81 & 15.51 \\
\hline 5 & CAT36RIVER & 62.79 & 18.80 & 25 & CAT13COUBA & 52.75 & 15.79 \\
\hline 6 & CAT37RIVER & 84.55 & 25.31 & 26 & CAT14COUBA & 63.5 & 19.01 \\
\hline 7 & MUL30RIVER & 103.67 & 31.04 & 27 & MUL26COUBA & 67.76 & 20.29 \\
\hline 8 & MUL31RIVER & 125.4 & 37.54 & 28 & MUL27COUBA & 52.54 & 15.73 \\
\hline 9 & MUL32RIVER & 105.41 & 31.56 & 29 & MUL28COUBA & 62.34 & 18.66 \\
\hline 10 & MUSSRIVER & 140.00 & 41.92 & 30 & MUSSCOUBA & 80.32 & 24.05 \\
\hline 11 & LMB21CATA & 57.01 & 17.07 & 31 & LMB4CAMP & 74.12 & 22.19 \\
\hline 12 & LMB24CATA & 59.55 & 17.83 & 32 & LMB5CAMP & 86.01 & 25.75 \\
\hline 13 & LMB25CATA & 64.07 & 19.18 & 33 & LMB6CAMP & 62.57 & 18.73 \\
\hline 14 & CAT22CATVE & 48.365 & 14.48 & 34 & CAT1CAMP & 63.22 & 18.93 \\
\hline 15 & CAT23CATA & 52.56 & 15.74 & 35 & CAT2CAMP & 77.99 & 23.35 \\
\hline 16 & CAT7CATA & 56.44 & 16.90 & 36 & САТЗСАMP & 70.71 & 21.17 \\
\hline 17 & MUL18CATA & 65.47 & 19.60 & 37 & MUL15CAMP & 67.48 & 20.20 \\
\hline 18 & MUL19CATA & 59.63 & 17.85 & 38 & MUL16CAMP & 57.31 & 17.16 \\
\hline 19 & MUL20CATA & 58.41 & 17.49 & 39 & MUL17CAMP & 72.16 & 21.60 \\
\hline 20 & MUSSCATA & 81.03 & 24.26 & 40 & MUSSCAMP & 77.68 & 23.26 \\
\hline
\end{tabular}


Table 8. Trace element ranges ( $\mu \mathrm{g} / \mathrm{g}$, dry weight) detected in fish and bivalves from the prediversion studies at Caernarvon (1990-91) and Davis Pond (2001) in Louisiana.

[Caernarvon data are from Conzelmann and others (1996); shaded boxes indicate a twofold or greater difference at the high end of the range compared with its counterpart from the other study]

\begin{tabular}{|c|c|c|c|c|}
\hline Element & \multicolumn{2}{|c|}{ Fish tissue } & \multicolumn{2}{|c|}{ Bivalve tissue } \\
\hline Aluminum & $4.4-1,040$ & $15.82-1,598.87$ & $18.8-71.8$ & $422.26-1,040$ \\
\hline Arsenic & $0.33-6.26$ & $0.49-2.6$ & $3.48-5.69$ & $3.54-15.03$ \\
\hline Barium & $1.8-133.0$ & $1.3-152.43$ & $3.8-24.4$ & $22.20-48.50$ \\
\hline Boron & $1.06-7.17$ & $1.89-2.05$ & $4.44-11.30$ & $1.42-2.21$ \\
\hline Chromium & $0.5-92.3$ & $1.96-21.46$ & $0.7-3.3$ & $1.43-3.35$ \\
\hline Copper & $1.11-26.30$ & $0.98-13.77$ & $75.3-295$ & $6.76-15.97$ \\
\hline Iron & $8.9-176.0$ & $26.04-1,443.13$ & $40.6-136.9$ & $492.39-2,900$ \\
\hline Mercury & $0.025-0.79$ & $0.17-0.48$ & $0.06-0.46$ & $0.08-0.20$ \\
\hline Lead & $1.5-296$ & $0.49-18.3$ & $13.0-35.8$ & $0.49-1.20$ \\
\hline Selenium & $0.34-3.47$ & $0.49-2.32$ & $1.49-3.35$ & $1.68-5.93$ \\
\hline Strontium & $5.1-561$ & $13.81-585.08$ & $9.7-46.9$ & $10.6-19.55$ \\
\hline Vanadium & $0.53-1.67$ & $0.48-9.38$ & $0.72-1.23$ & $0.49-2.91$ \\
\hline Zinc & 24-279 & $27.63-125.4$ & $398-4,760$ & $77.68-140$ \\
\hline
\end{tabular}


Table 9. Eaglet nest and sample IDs and observations on food items in or near nest.

[Nest ID numbers of the Louisiana Department of Wildlife and Fisheries are presented in parentheses in nest and sample ID column; nests in the experimental area are coded "S," and nests in the reference areas are coded "H"]

\begin{tabular}{llc} 
Nest and sample ID & Food items & Comments \\
\hline
\end{tabular}

S156 and S157 Skull of 24-inch catfish $~ 2.5 \mathrm{lb}$ at base of nest. Freshly killed nutria

(WLF 107) (Myocastor coypus) pup in nest.

Nest in sparse grove of cypress.

$\mathrm{S} 158$

(WLF 188)

H169

(WLF 154)

H160

(WLF 085)

H 159

(WLF 108)
Skull of medium-sized nutria and a killdeer (Charadrius collaris) wing at the base of nest, an American coot (Fulica americana) wing in nest.

No evidence of food items.

Skull of marsh rabbit (Sylvilagus palustris) in nest.

Skull of nutria, northern shoveler duck (Anas clypeata) at base of nest. Mullet in nest.
Nest at the edge of a cypress grove.

Tree unstable and in flooded area.

One eaglet had damaged eye, likely fratricide, so no banding or sampling. Flotant marsh, near the edge of cypress grove.

Nest at the edge of a cypress grove. 
species of fish and two species of mussels from four sites near the Davis Pond freshwater diversion structure. Aquatic animals were representatives of potential eagle prey. Levels of contaminants were also determined from whole blood of eaglets in the diversion area and in a reference area. It was not unexpected that the different fish and mussel species would show varied biological responses and contaminant burdens.

The current study's experimental design focused on a limited group of animals as compared with the Caernarvon studies (Conzelmann and others, 1996). Mussels are primary consumers and sessile filter feeders in close association with the benthos. They bioaccumulate heavy metals and organic compounds more readily than do many other aquatic organisms (Naimo and others, 1992). Mollusks reflect bioavailable concentrations of contaminants because of the low activity of their metabolic systems (Stegeman and Lech, 1991); not all species of mollusks have decontamination enzymes such as monooxygenase enzymes (Beyer and others, 1996). Mullet are planktivores that consume relatively minute living and dead vegetable matter. Mullet from the Mississippi River are able to migrate to oxbows off the river (C. Demas, U.S. Geological Survey, oral commun.). Catfish are opportunitistic omnivores, eating live or dead creatures as well as vegetative material. Largemouth bass are carnivores that feed in the water column. Eagles are opportunistic carnivores (Dugoni, 1980), so they will feed on readily available food sources, including carrion. They also catch live fish swimming near the surface or in shallow waters.

Trophic transfer along the food chain can be an important route for the uptake and accumulation of heavy metals. Metals are naturally found in the environment, but anthropogenic emissions associated with urban and industrial activities contribute to increased metal levels in some ecosystems. Metals in water can be carried over large distances, and salinity affects metal speciation and solubility. Therefore, metal bioavailability depends on amounts as well as on the characteristics of the receiving waters. Metals can bind to various ligands to form complexes that have their own biological activity. Additive as well as ameliorative effects exist among metals, and the accumulation of particular elements differs among taxa (Mance, 1987; Schmitt, 2002), as was seen in the current study. Species-dependent subcellular metal localizations and metal speciation are sometimes seen in animals, as they were with zinc and cadmium (van Campenhout and others, 2007). The hematological systemthrough which oxygen carrying capacity can be impacted (Wu and Deng, 2006) - is a target for cadmium (Sorenson, 1991). Adult birds can suffer health impairment or death when subjected to high concentrations of some metals, such as mercury and lead (Eisler, 1999). Metals such as chromium, manganese, and lead can be passed to eggs by hens (Gochfeld, 1997). Ingestion of chromium ${ }^{+6}$ by the hen reduces egg hatchability (Gochfeld, 1997). Feathers of raptors are potentially suitable biomonitors for environmental heavy metal pollution, but external contamination (from the atmosphere or preening) can increase concentrations measured (Dauwe and others, 2003). Concentrations of some elements in the blood decrease during the molt (Dauwe and others, 2003). These facts would need to be considered if feathers were to be used in biomonitoring.

The ways in which birds react to environmental conditions as individuals, populations, or communities depend on their resilience or how they can tolerate or accommodate stress and disturbances. In the current study, the nesting results indicated that the eagles are performing equally well in the two areas studied, experimental and reference. Food availability and potential nesting habitat dictate the natural distribution of a breeding raptor population (Newton, 1976; McEwan, 1977), suggesting that nesting density may be dependent on food availability rather than territoriality.

If eagles are exposed to contaminants, it is primarily through their diet. The numbers of bald eagles in North America declined after World War II primarily because of the eggshell-thinning effects of $p, p$ '-DDE. After the ban of DDT, the numbers of bald eagles increased, but not uniformly, because habitat availability, degree of human disturbance to nesting animals, and the concentrations of environmental contaminants in the prey of the nesting eagles (Bowerman and others, 1995) influenced success. The EPA ambient water-quality criterion for DDT is $0.15 \mu \mathrm{g} / \mathrm{g}$ ww in fish for the protection of reproduction of the brown pelican (Pelecanus occidentalis), the most sensitive species evaluated (Schmitt, 2002), whereas for other avian species the range is $1-3 \mu \mathrm{g} / \mathrm{g}$ ww. Crude oil and DDE exposure to nestlings depresses corticosterone levels, which alters WBC counts and thereby can cause an immunosuppressive effect (Rattner and Eastin, 1981). These compounds also influence growth and survivability (Bowerman and others, 2002). Increases in corticosterone induction are related to increases in DDE and PCBs, so the increases show promise as a biomarker for bald eagles (Bowerman and others, 2002). The effects of environmental toxicants on bald eagle reproduction have been documented for egg hatchability, but few data are available on survivability of hatched young that are exposed to those toxicants (Bowerman and others, 2002). In the current study, $p, p$ '-DDT was detected in one catfish at Bayou Couba (CAT12COUBA, fish ID 24) at $0.42 \mu \mathrm{g} / \mathrm{g}$ ww, this being above the NCBP geometric mean of $0.03 \mu \mathrm{g} / \mathrm{g}$ ww (Schmitt, 2002). In the current study, reference sites had lower 10-year productivities ( 0.77 young occupied nest) than did study sites (1.07 young per occupied nest). The reference sites were below the healthy level of 1.0 young per occupied nest for bald eagles but above the level for population stability of 0.7 .

Molecular and cellular responses are believed to be among the most sensitive and earliest detectable biomarker responses. An example that clearly links biochemical and populationlevel effects is the effect of DDE on avian eggshells. Laboratory studies showed that DDE reduced the activity of calcium-magnesium pumps in the shell gland epithelium and thus reduced the movement of calcium from the blood to the site of shell deposition (Lundholm, 1993).

In a study in northeastern U.S. bays in which estuarine fish 
were studied to explore the relationship between contaminated habitats and biological effects, the primary pathological conditions related to contaminant distributions included giant cells in the tubular epithelium of kidney, MA proliferation in the kidney, necrotizing granulomas in the kidney, and biliary hyperplasia in the liver (Zdanowicz and others, 1986). Increase in the number or size of MAs has been used as an indicator of environmental degradation in monitoring programs (Zdanowicz and others, 1986; Bucke and others, 1992; Fournie and others, 2001). Field and laboratory studies have used MAs as indicators of environmental stress (Wolke, 1992; Agius and Roberts, 2003). Increases in MAs have been shown to be a result of exposure to metals such as mercury (Meinelt and others, 1997), pulp mill effluent (Couillard and Hodson, 1996), dioxins (van der Weiden and others, 1994), crude oil (Khan and Kiceniuk, 1984), PCBs (Pierce and others, 1980; Bowser and others, 1990; Anderson and others, 2003), and PAHs (Blazer and others, 1994).

Exposure to contaminant stressors can cause, in addition to swelling of the spleen, an accumulation of monocytic cells. Accumulation of these cells in livers and spleens has been associated with organic contaminants and low dissolved oxygen (Fournie and others, 2001). Macrophages are triggered in immune response to digest foreign particles and dead cells. In the current study, MAs were measured by using digital imaging of histological spleen sections; results indicated that the total area of MAs and their frequency were significantly different between species, where values were higher in mullet than in the other species $(P<0.0055$ and $P<0.0014$, respectively). For both MA biomarkers, there were some significant species and site interactions. When tested with nonparametric analyses, EROD enzyme levels in largemouth bass were significantly higher at the Mississippi River than at Lake Cataouatche and Bayou Couba ( $P=$ 0.0390).

Stress can be either beneficial or detrimental on an animal's system. In the current study, the concept of hormesis may be relevant in that as organisms grow and experience slight stresses, their physiological function can increase (Anderson, 1990), therefore increasing their ability to withstand the stress. However, stress may compromise the functioning of defense mechanisms such that plasma cortisol is induced, thereby increasing vulnerability to invading pathogens, including parasites. Therefore, such interactions should be considered when examining possible impacts of stressors on animals.

In the current study, contaminant levels were generally higher in samples obtained from the Mississippi River sampling site, and interspecific differences were often noted. Contaminant levels in fishes and bivalves were generally lower than those detected in samples from the Caernarvon freshwater prediversion study of 1990 (Conzelmann and others, 1996). In the current study, OCs were detectable in 67 percent of the fish from the Mississippi River site, ranging from 0.15 to $1.09 \mu \mathrm{g} / \mathrm{g}$ ww. From the other three sites, 11 percent of the fish contained detectable levels of OCs. In each sample in which total OC was reported, $p, p$ '-DDE and total PCBs were detected in all but one animal (table 3 ). In the current study, the range of total PCBs was from 0.059 to $0.79 \mathrm{ppm}$ ww, with one value (LMB35RIVER, fish ID 3) exceeding the NCBP geometric mean (0.39 ppm ww) (Schmitt and others, 1990) (table 1). The level of $p, p$ '-DDE in one Mississippi River largemouth bass (LMB35RIVER, fish ID 3) exceeded the geometric mean for bass from the Mississippi Embayment (Schmitt, 2002). One catfish from Bayou Couba contained $p$, $p$ '-DDT above the NCBP geometric mean of $0.03 \mu \mathrm{g} / \mathrm{g}$ ww (Schmitt and others, 1990) (table 1). Overall, in the current study, $p, p$ '-DDE and total PCBs were the most frequently detected OCs.

In the current study, detectable levels of PAHs were seen in each sample (fig. 10), and there were statistical differences in accumulation in a fish species. A trend of higher levels in mullet was apparent in the Mississippi River. This trend may be due to mullet feeding behavior and to the fact that higher levels of PAHs are found in sediments than in the water column. Levels of PAHs were higher in Mississippi River aquatic animals than in those from marsh sites. The single PAH compound detectable in every fish was BaP, with the range $0.014-0.53 \mu \mathrm{g} / \mathrm{g}$, with four fish showing levels over $0.10 \mu \mathrm{g} / \mathrm{g}$ (app. 1, table 1-6). PAHs act as inducers of decontamination enzymes in the liver. In water, equilibrium can be reached within 24 hours after first exposure in trout (Kennedy and Law, 1990), but responses of different fish species vary (Eisler, 1999). Deciphering effects of PAHs in vertebrates is challenging because of the decontamination processes and fates of the compounds. Invertebrates have lower rates of PAH metabolism than do fish (Stegeman and Lech, 1991).

Arsenic was detected in 36 percent of fish, with levels ranging from 0.49 to $2.6 \mu \mathrm{g} / \mathrm{g} \mathrm{dw}$ (fig. 15), and most samples had higher levels than the NCBP 85th percentile of $0.92 \mu \mathrm{g} / \mathrm{g}$ $\mathrm{dw}$ (Schmitt and Brumbaugh, 1990). Planktivorous mullet tended to accumulate arsenic to levels greater than those of the other species. Five of the six eaglet blood samples had detectable levels of arsenic, with a maximum of $0.212 \mu \mathrm{g} / \mathrm{g}$ ww (fig. 14; table 7). In the current study, each aquatic animal sample had a detectable level of barium (fig. 17), with mullet displaying the most elevated levels at the Mississippi River. Each eaglet had detectable barium levels in their blood, as much as $0.352 \mu \mathrm{g} / \mathrm{g}$ ww (fig. 14; table 7).

Of the fish having levels above the cadmium detection limit, 80 percent of those came from the Mississippi River site (fig. 19), where the maximum level was $0.15 \mu \mathrm{g} / \mathrm{g} \mathrm{dw}(0.044$ $\mu \mathrm{g} / \mathrm{g} \mathrm{ww}$ ), below the 85 th percentile of $0.17 \mu \mathrm{g} / \mathrm{g} \mathrm{dw}$ (Schmitt and Brumbaugh, 1990) (table 1). The 85th percentile from the NCBP for copper was $1.00 \mu \mathrm{g} / \mathrm{g}$ fw $(3.4 \mu \mathrm{g} / \mathrm{g} \mathrm{dw}$ ) (Schmitt and Brumbaugh, 1990) (table 1), and over 33 percent of fish in the current study displayed higher levels, from 0.98 to $13.77 \mu \mathrm{g} / \mathrm{g}$ 
$\mathrm{dw}(0.28$ to $3.99 \mu \mathrm{g} / \mathrm{g} \mathrm{ww})$ (fig. 21$)$.

Iron, manganese, barium, and aluminum, considered to be of low toxicity in hydrologic systems, were the most elevated in fish from the Mississippi River. In the current study, iron levels in striped mullet were significantly higher than those in blue catfish at the Mississippi River $(P=0.0003)$ and Lake Salvador $(P=0.0009)$. Lead levels in the Mississippi River mullet approached levels considered high in fish, but levels in eaglets were well below those considered injurious. In the BEST study of 1995-96 (Schmitt, 2002), the highest level of lead detected was $0.69 \mu \mathrm{g} / \mathrm{g}$ ww, with $0.20 \mu \mathrm{g} / \mathrm{g}$ ww being considered a high concentration. The NCBP 85th percentile for lead is $0.22 \mu \mathrm{g} / \mathrm{g}$ ww $(0.76 \mu \mathrm{g} / \mathrm{g} \mathrm{dw}$ ) (Schmitt and Brumbaugh, 1990) (table 1). In the current study, the minimum detection limit for lead was $0.48 \mathrm{ppm} \mathrm{dw}(0.14 \mathrm{ppm}$ ww) (fig. 25); therefore, a lowered limit would be helpful in postdiversion samplings. The range of mercury was $0.14-0.48$ $\mu \mathrm{g} / \mathrm{g} \mathrm{dw}(0.04-0.14 \mu \mathrm{g} / \mathrm{g} \mathrm{ww})$ (fig. 30), with the highest levels seen in largemouth bass at the southernmost sampling point within the diversion area, where methylation of mercury is not unexpected. Mercury was detected in each eaglet whole blood sample (0.025-0.085 $\mu \mathrm{g} / \mathrm{g} \mathrm{ww})$. Nickel levels in fish were relatively low, and no detectable nickel was found in eaglets. The 85th percentile from the NCBP for selenium was $2.52 \mu \mathrm{g} / \mathrm{g} \mathrm{dw}$ (Schmitt and Brumbaugh, 1990) (table 1), and in the current study, 81 percent of fish samples had measurable selenium, with notably high levels in the Mississippi River as high as $2.32 \mathrm{ppm} \mathrm{dw}(0.69 \mu \mathrm{g} / \mathrm{g} \mathrm{ww})$ in fish and a high of $5.93 \mu \mathrm{g} / \mathrm{g} \mathrm{dw}(1.78 \mu \mathrm{g} / \mathrm{g} \mathrm{ww})$ in mussels (fig. 32). The NCBP program lists the 85th percentile for zinc as $117.9 \mu \mathrm{g} / \mathrm{g}$ $\mathrm{dw}(34.2 \mu \mathrm{g} / \mathrm{g} \mathrm{ww})$ (Schmitt and Brumbaugh, 1990) (table 1). One mullet from the Mississippi River (MUL31RIVER, fish ID 8) had zinc concentrations above this level (fig. 35) at $125.4 \mu \mathrm{g} / \mathrm{g} \mathrm{dw}(37.54 \mu \mathrm{g} / \mathrm{g} \mathrm{ww})$, and eaglet blood had as much as $6.77 \mu \mathrm{g} / \mathrm{g}$ ww (fig. 14; table 7).

Hematology, a useful diagnostic tool for animal health, has been employed in establishing a blood profile for largemouth bass (Clark and others, 1979). Hematological effects can be detected by examination of the relative proportions of different blood cell types (Blaxhall, 1972). Largemouth bass displayed significantly lower WBCs with increasing AHs than did the other two fish species $(P=0.0003)$. There was a significant site effect in that WBCs in largemouth bass were higher at the Mississippi River than at Lake Salvador $(P=$ 0.0244) (fig. 5). For individual AH compounds, there was an interaction between fish species and n-decane, where mullet and largemouth bass had significantly higher levels than did catfish $(P=0.0175)$.

Postdiversion sampling will be done in a similar way, with some refinements. Postdiversion sampling will be conducted at similar sites as in the current study, with attempts to obtain aquatic animals from the Mississippi River as close to the structure intake as possible. Sampling events from fall through late winter or early spring should be attempted but may be influenced by weather events and water levels. The detection limits for several metals should be lowered, dioxins could be assessed in eaglet blood, and triazines in water could be investigated. Size ranges for adult fish will be limited, biomarker analyses will be attempted with only blue catfish in sample sizes of approximately 20 animals, and otoliths from each species can be obtained for aging fish. Overall, experimental design and results of the current study provided sound baseline information about the contaminants and their levels in three fish species, in bivalves, and in eaglet blood.

Contaminants found in blood of eaglets reflect their prey species, and based on the contaminant levels found in fish, eaglets may not be consuming primarily these species. Therefore, obtaining juvenile reptiles for contaminant analyses might be considered, as well as collecting greater blood volume and possibly analyzing blood plasma to measure OCs and PCBs. Postdiversion data will be compared with prediversion data to monitor changes.

\section{Acknowledgments}

We thank Sue Lauritzen (retired) and Paul Chadwick of NWRC for figures 1 and 2, respectively. We thank Mark McElroy, Andre LaFosse, and Ralph Allemand of LDWF for aquatic animal sampling under less than ideal conditions, and we thank Tom Hess and Jeb Linscomb of LDWF for assisting with eaglet sampling. Chip Graffe is thanked for professional tree-climbing services. We thank Paul LeBerg, University of Louisiana at Lafayette, Department of Biology; Rassa Dale of NWRC; and Darren Johnson of IAP Worldwide Services, Inc. (IAPWS), for help with statistics. Bruce Baird, formerly of the USACE, Paul Conzelmann, formerly of USFWS, and David Walther of USFWS are thanked for facilitating the project. Personnel acknowledged who facilitated biomarker data include Jaquie Craig, Rebecca White, Douglas Marsalis, and Eric Theall. We thank Chris Swarzenski (USGS), Jim Harvey (EPA), Bill Bowerman (Clemson University), and Jack Waide (NWRC) for reviewing a draft report, and we thank Beth Vairin and Christina Boudreaux (USGS) and Victoria Jenkins (IAPWS) for editorial review, layout, and production.

\section{References}

Aas, E., Baussant, T., Balk, L., Liewenborg, B., and Anderson, O.K., 2000, PAH metabolites in bile, cytochrome P4501A and DNA adducts as environmental risk parameters for chronic oil exposure-a laboratory experiment with Atlantic cod: Aquatic Toxicology, v. 51, no. 2, p. 241-258.

Adams, S.M., 2002, Biological indicators of aquatic ecosystem stress: Bethesda, Md., American Fisheries Society. 
Adams, S.M., Shugart, G.R., Southworh, G.R., and Hinton, D.E., 1990, Application of bioindicators in assessing the health of fish populations experiencing contaminant stress, in McCarthy, J.F., and Shugart, L.R., eds., Biomarkers of environmental contamination: Boca Raton, Fla., CRC Press, Lewis Publishers, p. 333-353.

Agius, C., and Roberts, R.J., 2003, Melano-macrophage centres and their role in fish pathology: Journal of Fish Diseases, v. 26, p. 499-509.

Anderson, D.P., 1990, Immunological indicators-effects of environmental stress on immune protection and disease outbreaks, in Adams, S.M., ed., Biological indicators of stress in fish: Bethesda, Md., American Fisheries Society, p. $38-50$.

Anderson, M.J., Cacela, D., Beltman, D., Teh, S.J., Okihiro, M.S., Hinton, D.E., Denslow, N., and Zelikoff, J.T., 2003, Biochemical and toxicopathic biomarkers assessed in smallmouth bass recovered from a polychlorinated biphenyl-contaminated river: Biomarkers, v. 8, p. 371-393.

Anthony, R.G., Frenzel, R.W., Isaaccs, F.B., and Garrett, M.G., 1994, Probable causes of nesting failures in Oregon's bald eagle population: Wildlife Society Bulletin, v. 22, p. 576-582.

Anulacion, B.F., Bill, B.D., and Collier, T.K., 1997, Stability of cytochrome P4501A-associated enzyme activity in cryogenically stored teleost liver samples: Chemosphere, v. 34, p. 2029-2039.

Arey, L.B., 1966, Developmental anatomy (7th ed.): Philadelphia, W.B. Saunders Co., p. 255-259.

Barnes, M.A., Power, G., and Downer, R.G.H., 1984, Stressrelated changes in lake whitefish (Coregonus clupeaformis): Canadian Journal of Fisheries and Aquatic Sciences, v. 41, p. 141-150.

Barton, B.A., Morgan, J.D., and Vijayan, M.M., 2002, Physiological and condition-related indicators of environmental stress in fish, in Adams, S.M., ed., Biological indicators of aquatic ecosystem stress: Bethesda, Md., American Fisheries Society, p. 111-148.

Barton, B.A., Schreck, C.B., and Barton, L.D., 1987, Effects of chronic cortisol administration and daily acute stress on growth, physiological conditions, and stress responses in juvenile rainbow trout: Diseases of Aquatic Organisms, v. 2, p. 173-185.

Baumann, P.C., Mac, M.J., Smith, S.B., and Harshbarger, J.C., 2003, Tumor frequencies in walleye (Stizostedion vitreum) and brown bullhead (Ameiurus nebulosus) and sediment contaminants in tributaries of the Laurentian Great Lakes: Canadian Journal of Fisheries and Aquatic Sciences, v. 48, p. 1804-1810.
Berntssen, M.H.G., Aatland, A., and Handy, R.D., 2003, Chronic dietary mercury exposure causes oxidative stress, brain lesions, and altered behaviour in Atlantic salmon (Salmo salar) parr: Aquatic Toxicology, v. 65, p. 55-72.

Beyer, W.N., Heinz, G.H., and Redmon-Norwood, A.W., 1996, Environmental contaminants in wildlife: Boca Raton, Fla., CRC Press, Inc.

Blaxhall, P.C., 1972, The hematological assessment of the health of freshwater fish: Journal of Fish Biology, v. 4, p. 593-604.

Blazer, V.S., Facey, D.E., Fournie, J.W., Courtney, L.A., and Summers, J.K., 1994, Macrophage aggregates as indicators of environmental stress, in Stolen, J.S., and Fletcher, T.C., eds., Modulators of fish immune responses, v. 1: Fair Haven, N.J., SOS Publications, p. 169-185.

Blazer, V.S., Fournie, J.W., and Weeks-Perkins, B.A., 1997, Macrophage aggregates-biomarker for immune function in fishes?, in Dwyer, F.J., Doane, T.R., and Hinman, M.L., eds., Environmental toxicology and risk assessmentmodeling and risk assessment (v. 6), ASTM STP 1317: American Society for Testing and Materials, p. 360-375.

Bowerman, W.W., Best, D.A., Giesy, J.P., Shieldcastle, M.C., Meyer, M.W., Postupalsky, S., and Sikarskie, J.G., 2003, Associations between regional differences in polychlorinated biphenyls and dichlorodiphenyldichloroethylene in blood of nestling bald eagles and reproductive productivity: Environmental Toxicology and Chemistry, v. 22, p. 371-376.

Bowerman, W.W., Giesy, J.P., Best, D.A., and Kramer, V.J., 1995, A review of factors affecting productivity of bald eagles in the Great Lakes region-implications for recovery: Environmental Health Perspectives, v. 103, p. 51-59.

Bowerman, W.W., Mehne, C.J., Best, D.A., Refsal, K.R., Lombardini, S., and Bridges, W.C., 2002, Adrenal corticotropin hormone and nestling bald eagle corticosterone levels: Bulletin of Environmental Contamination and Toxicology, v. 68, p. 355-360.

Bowerman, W.W., Stickle, J.E., Sikarskie, J.G., and Giesy, J.P., 2000, Hematology and serum chemistries of nestling bald eagles (Haliaeetus leucocephalus) in the lower peninsula of MI, USA: Chemosphere, v. 41, p. 1575-1579.

Bowser, P.R., Martineau, D., Sloan, R., Brown, R., and Carusone, C., 1990, Prevalence of liver lesions in brown bullheads from a polluted site and a nonpolluted site on the Hudson River, New York: Journal of Aquatic Animal Health, v. 2, p. 177-181.

Boyd, C.E., 1979, Water quality in warmwater fish ponds: Auburn, Ala., Auburn University. 
Brigelius-Flohe, R., 1999, Tissue-specific functions of individual glutathione peroxidases: Free Radical Biology and Medicine, v. 27, p. 951-965.

Brumbaugh, W.G., and Kane, D.A., 1985, Variability of aluminum concentrations in organs and whole bodies of smallmouth bass (Micropterus dolomieui): Environmental Science and Technology, v. 19, p. 828-831.

Bucheli, T.D., and Fent, K., 1995, Induction of cytochrome P450 as a biomarker for environmental contamination in aquatic ecosystems: Critical Reviews in Environmental Science and Technology, v. 25, no. 3, p. 201-268.

Buchman, M.F., 2003, NOAA Screening Quick Reference Tables: National Oceanic and Atmospheric Administration Coastal Protection and Restoration Division, p. 99-1, 1 p.

Bucke, D., Vethaak, A.D., and Lang, T., 1992, Quantitative assessment of melanomacrophage centres (MMCs) in dab (Limanda limanda) along a pollution transect in the German Bight: Marine Ecology Progress Series, v. 91, p. 193-196.

Buehler, D.A., 2000, Bald eagle (Haliaeetus leucocephalus), in Poole, A., and Gill, F., eds., The birds of North America, no. 506: Philadelphia, The Birds of North America, Inc.

Busacker, G.P., Adelman, I.R., and Goolish, E.M., 1990, Growth, in Schreck, C.B., and Moyle, P.B., eds., Methods for fish biology: Bethesda, Md., American Fisheries Society, p. 363-387.

Bush, B., Bennett, A.H., and Snow, J.T., 1986, Polychlorobiphenyl congeners P,P'-DDE, and sperm function in humans: Archives of Environmental Contamination and Toxicology, v. 15, p. 333-341.

Carlander, K., 1969, Handbook of freshwater fishery biology, v. 1: Ames, The Iowa State University Press, 752 p.

Carlander, K.D., 1977, Life history data on centrarchid fishes of the United States and Canada (1st ed.): Ames, Iowa State University Press, $431 \mathrm{p}$.

Clark, S., Whitmore, D.H., and McMahon, R.F., 1979, Considerations of blood parameters of largemouth bass, Micropterus salmoides: Journal of Fish Biology, v. 14, p. 147-158.

Code of Federal Regulations, 2006, Definition and procedure for the determination of the method detection limit? Revision 1.11. Title 40, pt. 136, Guidelines establishing test procedures for the analysis of pollutants, app. B, p. 319-322.

Colborn, T., 1991, Epidemiology of Great Lakes bald eagles: Journal of Toxicology and Envrionmental Health, v. 33, p. 395-453.
Collins, M.R., 1985, Species profiles-life histories and environmental requirements of coastal fish and invertebrates (south Florida)—striped mullet: U.S. Fish and Wildlife Service Biological Report 82 (11.34), U.S. Army Corps of Engineers, TR EL-82-4, 11 p., last accessed April 28, 2008, at http://www.nwrc.usgs.gov:80/publications/specintro.htm

Conzelmann, P.J., and Rabot, R., 1994, Metals, organochlorine pesticides, and polychlorinated biphenyls in bald eagles of coastal Louisiana: Lafayette, La., U.S. Fish and Wildlife Service, Southeast Region, Ecological Services, LA-944F01.

Conzelmann, P.J., Schultz, T.W., and Vogl, B.T., 1996, Caernarvon freshwater diversion contaminants monitoring study, 1990-1994: Atlanta, Ga., LFO-EC-96-02, study identifiers 91-4-4249 and 90-4-4249, $71 \mathrm{p}$.

Couillard, C.M., and Hodson, P.V., 1996, Pigmented macrophage aggregates - a toxic response in fish exposed to bleached-kraft mill effluent?: Environmental Toxicolology and Chemistry, v. 15, p. 1844-1854.

Crawford, J.K., and Luoma, S.N., 1993, Guidelines for studies of contaminants in biological tissues for the National WaterQuality Assessment Program: U.S. Geological Survey Open-File Report 92-494, 69 p.

Custer, T.W., Franson, J.C., and Pattee, O.H., 1984, Tissue lead distribution and hematologic effects in American kestrels (Falco sparverius L.) fed biologically incorporated lead: Journal of Wildlife Diseases, v. 20, p. 39-43.

Dauwe, T., Bervoets, L., Pinxten, R., Blust, R.E., and Eens, M., 2003, Variation of heavy metals within and among feathers of birds of prey-effect of molt and external contamination: Environmental Pollution, v. 124, p. 429436.

de Vlaming, V., Grossman, G., and Chapman, F., 1982, On the use of the gonadosomatic index: Comparative Biochemistry and Physiology, v. 73A, p. 31-39.

Diniz, M.S., Peres, I., and Pihan, J.C., 2005, Comparative study of the estrogenic responses of mirror carp (Cyprinus carpio) exposed to treated municipal sewage effluent (Lisbon) during two periods in different seasons: Science of the Total Environment, v. 349, p. 129-139.

Dowd, P.F., Mayfield, G.U., Coulon, D.P., Graves, J.B., and Newsom, J.D., 1985, Organochlorine residues in animals from three Louisiana watersheds in 1978 and 1979: Bulletin of Environmental Contaminants and Toxicology, v. 34, p. 832-841.

Dugoni, J.A., 1980, Habitat utilization, food habits, and productivity of nesting southern bald eagles in Louisiana: Baton Rouge, Louisiana State University, 150 p. 
Eisler, R., 1999, Contaminant hazard reviews 1-35, 1985 1999: U.S. Geological Survey Biological Science Report USGS/BRD/BSR--1997-0002

Elskus, A.A., and Stegeman, J.J., 1989, Induced cytochrome P-450 in Fundulus heteroclitus associated with environmental contamination by polychlorinated bipheynyls and polynuclear aromatic hydrocarbons: Marine Environmental Research, v. 27, p. 31-50.

Enserink, E.L., Maas-Diepeveen, J.L., and Van Leeuwen, C.J., 1991, Combined effects of metals - an ecotoxicological evaluation: Water Research, v. 25, p. 679-687.

Facey, D.E., Blazer, V.S., Gasper, M.M., and Turcotte, C.L., 2005, Using fish biomarkers to monitor improvements in environmental quality: Journal of Aquatic Animal Health, v. 17 , p. 263-266.

Farag, A.M., Stansburg, M.A., Hogstrand, C., MacConnell, E., and Bergman, H.L., 1995, The physiological impairment of free ranging brown trout exposed to metals in the Clark Fork River, Montana: Canadian Journal of Fisheries and Aquatic Sciences, v. 52, p. 2038-2050.

Farag, A.M., Woodward, D.F., Goldstein, J.N., Brumbaugh, W., and Meyer, J.S., 1998, Concentrations of metals associated with mining waste in sediments, biofilm, benthic macroinvertebrates, and fish from the Coeur d'Alene River Basin, Idaho: Archives of Environmental Contamination and Toxicology, v. 34, p. 119-127.

Fimreite, N., 1979, Accumulation and effects of mercury on birds, in Nriagu, J.O., ed., The biogeochemistry of mercury in the environment: Elsevier, p. 601-627.

Fournie, J.W., Summers, J.K., Courtney, L.A., Engle, V.D., and Blazer, V.S., 2001, Utility of splenic macrophage aggregates and an indicator of fish exposure to degraded environments: Journal of Aquatic Animal Health, v. 13, p. $105-116$

Frenzel, R.W., 1985, Environmental contaminants and ecology of bald eagles in southcentral Oregon: Corvallis, Oregon State University, Ph.D. thesis, 143 p.

Frenzel, R.W., and Anthony, R.G., 1989, Relationship of diets and environmental contaminants in wintering bald eagles: Journal of Wildlife Management, v. 53, p. 792-802.

Friedmann, A.S., Watzin, M.C., Leiter, J.C., and BrinckJohnsen, T., 1996, Effects of environmental mercury on gonadal function in Lake Champlain northern pike (Esox lucius): Bulletin of Environmental Contamination and Toxicology, v. 56, p. 486-492.

Furness, R.W., 1996, Cadmium in birds, in Environmental contaminants in wildlife-interpreting tissue concentrations: New York, CRC Lewis Publishers, p. 389-404.
Garrison, C.R., 1998, Statistical summary of surface-water quality in Louisiana-Mississippi River mainstem, 1905-95: U.S. Geological Survey Water Resources Technical Report, Louisiana Department of Transportation and Development no. 551,91 p.

Ghosh, U., Zimmerman, J.R., and Luthy, R.G., 2003, PCB and PAH speciation among particle types in contaminated harbor sediments and effects on PAH bioavailability: Environmental Science and Technology, v. 37, p. 22092217.

Gochfeld, M., 1997, Spatial patterns in a bioindicator-heavy metal and selenium concentration in eggs of herring gulls (Larus argentatus) in the New York Bight: Archives of Environmental Contamination and Toxicology, v. 33, p. $63-70$.

Goede, R.W., and Barton, B.A., 1990, Organismic indices and an autopsy-based assessment as indicators of health and condition in fish, in Adams, S.M., ed., Biological indicators of stress in fish: Bethesda, Md., American Fisheries Society, p. 93-108.

Grimsley, K.J., and D’Arconte, P.J., 2003, Annotated bibliography of water-related information and studies, Acadian-Pontchartrain study unit, Louisiana and Mississippi, 1863-2000: U.S. Geological Survey National Water-Quality Assessment Program OFR 03-9, p. 1-256, last accessed April 25, 2008, at http://la.water.usgs.gov/ pdfs/NAWQABiblio.pdf

Grubb, T.G., Wiemeyer, S.N., and Kiff, L.F., 1990, Eggshell thinning and contaminant levels in bald eagle eggs from Arizona, 1977 to 1985: The Southwestern Naturalist, v. 35, p. 298-301.

Guthrie, R.K., and Cherry, D.S., 1979, Trophic level accumulation of heavy metals in a coal ash basin drainage: Water Resources Bulletin, v. 15, p. 244-248.

Hammerschmidt, C.R., Sandheinrich, M.B., Wiener, J.G., and Rada, R.G., 2002, Effects of dietary methylmercury on reproduction of fathead minnows: Environmental Science and Technology, v. 36, p. 877-883.

Hase, A., and Hites, R.A., 1978, On the origin of polycyclic aromatic hydrocarbons in the aqueous environment, in Keith, L.H., ed., Identification and analysis of organic pollutants in water: Ann Arbor, Mich., Ann Arbor Science.

Heinz, G.H., 1996, Selenium in birds, in Beyer, W.N., Heinz, G.H., and Redmon-Norwood, A.W., eds., Environmental contaminants in wildlife-interpreting tissue concentrations: New York, CRC Lewis Publishers, p. 447-458. 
Henrich, M.D., Hindrichs, A.E., and Fleming, M.B., 1995, Water quality management division, Mississippi River toxics inventory project-fish and shellfish sampling plan, final report-July 1995, results from 1990-1994 sampling, 29 p.

Hoffman, D.J., Rice, C.D., and Kubiak, T.J., 1996, PCBs and dioxins in birds, in Beyer, J., Heinz, G.H., and RedmonNorwood, A.W., eds., Environmental contaminants in wildlife-interpreting tissue concentrations: New York, CRC Lewis Publishers, p. 165-207.

Hui, C.A., 2002, Concentrations of chromium, manganese, and lead in air and in avian eggs: Environmental Pollution, v. 120, p. 201-206.

Kennedy, C.J., and Law, F.C.P., 1990, Toxicokinetics of selected polycyclic aromatic hydrocarbons in rainbow trout following different routes of exposure: Environmental Toxicology and Chemistry, v. 9, p. 133-139.

Khan, R.A., and Billiard, S.M., 2007, Parasites of winter flounder (Pleuronectes americanus) as an additional bioindicator of stress-related exposure to untreated pulp and paper mill effluent - a five year study: Archives of Environmental Contamination and Toxicology, v. 52, p. 243-250.

Khan, R.A., and Kiceniuk, J., 1984, Histopathological effects of crude oil on Atlantic cod following chronic exposure: Canadian Journal of Zoology, v. 62, p. 2038-2043.

Kime, D.E., 1998, Disruption of liver function, in Endocrine disruption in fish: Norwell, Mass., Kluwer Academic Publishers, p. 201-246.

Lane, R.R., Day, J.W., Kemp, G.P., and Demcheck, D.K., 2001, The 1994 experimental opening of the Bonne Carre Spillway to divert Mississippi River water into Lake Pontchartrain, Louisiana: Ecological Engineering, v. 17, p. 411-422.

Lee, R.M., Gerking, S.B., and Jezierska, B., 1983, Electrolyte balance and energy mobilization in acid-stressed rainbow trout, Salmo gairdneri, and their relation to reproductive success: Environmental Biology of Fish, v. 8, p. 115-123.

Lemly, A.D., 1996, Selenium in aquatic organisms, in Beyer, W.N., Heinz, G.H., and Redmon-Norwood, A.W., eds., Environmental contaminants in wildlife-interpreting tissue concentrations: New York, CRC Lewis Publishers, p. $427-445$.

Louisiana Department of Environmental Quality, 1992, Mississippi River toxics inventory project-fish and shellfish sampling plan, interim report-May 1992, first year of data: Baton Rouge, La., Water Quality Management Division, Planning and Assessment Section, Surveillance Section, $23 \mathrm{p}$.
Lundholm, C.E., 1993, Inhibition of prostaglandin synthesis in eggshell gland mucosa as a mechanism for P,P'-DDEinduced eggshell thinning in birds - a comparison of ducks and domestic fowls - comparative biochemistry and physiology part C: Comparative Pharmacology and Toxicology, v. 106, p. 389-394.

Mance, G., 1987, Pollution threat of heavy metals in aquatic environments: Essex, England, Elsevier.

Manheim, F.T., and Hayes, L., 2002, Lake Pontchartrain basin-bottom sediments and related environmental resources: U.S. Geological Survey Professional Paper 1634.

McEwan, L.C., 1977, Nest site selection and productivity of the southern bald eagle: Gainesville, University of Florida, M.S. thesis, $64 \mathrm{p}$.

Meade, R.H., 1995, Contaminants in the Mississippi River 1987-1992, USGS: U.S. Geological Survey Circular 1133, $140 \mathrm{p}$.

Meinelt, T.H., Krüger, R., Pietrock, M., Osten, R., and Steinberg, C., 1997, Mercury pollution and macrophage centres in pike (Esox lucius) tissues: Environmental Science and Pollution Research, v. 4, p. 32-36.

Myers, M.S., and Fournie, J.W., 2002, Histopathological biomarkers as integrators of anthropogenic and environmental stressors, in Adams, S.M., ed., Biological indicators of aquatic ecosystem stress: Bethesda, Md., American Fisheries Society, p. 221-288.

Naimo, T.J., Atchison, G.J., and Holland-Bartels, L.E., 1992, Sublethal effects of cadmium on physiological responses in the pocketbood mussel, Lampsilis ventricosa: Environmental Toxicology and Chemistry, v. 11, p. 10131021.

National Research Council National Academy of Sciences Panel on Mercury, 1978, An assessment of mercury in the environment - a report: Washington, National Academy of Sciences, $185 \mathrm{p}$.

National Toxicology Program, 2002, Report on carcinogens (10th ed.) — carcinogen profiles: Research Triangle Park, N.C., U.S. Department of Health and Human Services, Public Health Service, National Toxicology Program 263 p.

Newton, I., 1976, Population limitation in diurnal raptors: Canadian Field-Naturalist, v. 90, p. 274-300.

Noaksson, E., Tjärnlund, U., Bosveld, A.T.C., and Balk, L., 2001, Evidence for endocrine disruption in perch (Perca fluviatilis) and roach (Rutilus rutilus) in a remote Swedish lake in the vicinity of a public refuse dump: Toxicology and Applied Pharmacology, v. 174, p. 160-176. 
Olsson, A., Valters, K., and Burreau, S., 2000, Concentrations of organochlorine substances in relation to fish size and trophic position - a study on perch (Perca fluviatilis L.): Environmental Science and Technology, v. 34, no. 23, p. 4878-4886.

Orihel, D.M., Paterson, M.J., Blanchfield, P.J., Bodaly, R.A., and Hintelmann, H., 2007, Experimental evidence of a linear relationship between inorganic mercury loading and methylmercury accumulation by aquatic biota: Environmental Science and Technology, v. 41, p. 49524958.

Pierce, K.V., McCain, B.B., and Wellings, S.R., 1980, Histopathology of abnormal livers and other organs of starry flounder (Platichthys stellatus) (Pallus) from the estuary of the Duwamish River, Seattle, Washington, USA: Journal of Fish Diseases, v. 3, p. 81-91.

Plachy, J., 2001, Minerals yearbook-cadmium: Washington, D.C., U.S. Geological Survey, last accessed April 25, 2008, at http://minerals.usgs.gov/minerals/pubs/commodity/ cadmium/140498.pdf

Poels, C.L.M., van der Gaag, M.A., and van der Kerkhoff, J.F.J., 1980, An investigation into the longterm effects of Rhine water on rainbow trout: Water Research, v. 14, p. 1029-1035.

Ralph, J.L., Orgebin-Crist, M., Kareyre, J., and Nelson, C.C., 2003, Disruption of androgen regulation in the prostate by the environmental contaminant hexachlorobenzene: Environmental Health Perspectives, v. 111, p. 461-466.

Ralston, C.R., Blackwell, J.L., and Ralston, N.V.C., 2006, Effects of dietary selenium and mercury on house crickets (Acheta domesticus L.)_implications of environmental co-exposures: Environmental Bioindicators, v. 1, p. 98-109.

Rattner, B.A., and Eastin, W.C., Jr., 1981, Plasma corticosterone and thyroxine conentrations during chronic ingestion of crude oil in mallard ducks (Anas platyrhynchos): Comparative Biochemistry and Physiology, v. $68 \mathrm{C}$, p. $103-107$.

Rice, C.D., 2001, Fish immunotoxicology-understanding mechanism of action, in Schlenk, D., and Benson, W.H., eds., Target organ toxicity in marine and freshwater teleosts: New York, Taylor and Francis, p. 96-138.

Rice, C.D., and Arkoosh, M.R., 2002, Immunological indicators of environmental stress and disease susceptibility in fish, in Adams, S.M., ed., Biological indicators of aquatic ecosystem stress, p. 187-220.
Roche, H., Buet, A., Jonot, O., and Ramade, F., 2000, Organochlorine residues in European eel (Anguilla anguilla), crucian carp (Carassius carassius) and catfish (Ictalurus nebulosus) from Vaccares lagoon (French National Nature Reserve of Camargue)_effects on some physiological parameters: Aquatic Toxicology, v. 48, p. 443-459.

Ross, S.T., 2001, Inland fishes of Mississippi: Jackson, University Press of Mississippi, p. 1-624.

Schlenk, D., 2001, General mechanisms of toxicity, in Schlenk, D., and Benson, W.H., eds., Target organ toxicity in marine and freshwater fish: New York, Taylor and Francis, p. 1-25.

Schmitt, C.J., 1990, Persistent organochlorine and elemental contaminants in freshwater fish of the United States- the national contaminant biomonitoring program, in Gray, R.H., ed., Environmental monitoring, restoration and assessment—what have we learned?: Richland, Wash., U.S. Department of Energy, Pacific Northwest Laboratory, p. 5-14.

Schmitt, C.J., 2002, Biomonitoring of environmental status and trends (BEST) program-environmental contaminants and their effects on fish in the Mississippi River basin: U.S. Geological Survey Biological Science Report USGS/BRD/ BSR-2002-2004, last accessed April 25, 2007, at http:// www.cerc.usgs.gov/pubs/center/pdfDocs/BEST_1995.pdf

Schmitt, C.J., Blazer, V.S., Dethloff, G.M., Tillitt, D.E., Gross, T.S., Bryant, W.L., Jr., DeWeese, L.R., Smith, S.B., Goede, R.W., Bartish, T.M., and Kubiak, T.J., 1999, Biomonitoring of environmental status and trends (BEST) program-field procedures for assessing the exposure of fish to environmental contaminants: Columbia, Mo., U.S. Geological Survey Biological Resources Division Information and Technology Report USGS/BRD-19990007, iv + 35 p. + appendixes, last accessed August 20, 2007, at http://www.cerc.usgs.gov/pubs/BEST/layout-rev2. $p d f$

Schmitt, C.J., and Brumbaugh, W.G., 1990, National contaminant biomonitoring program-concentrations of arsenic, cadmium, copper, lead, mercury, selenium, and zinc in U.S. freshwater fish, 1976-1984: Archives of Environmental Contamination and Toxicology, v. 19, p. 731-747.

Schmitt, C.J., and Bunck, C.M., 1995, Persistent environmental contaminants in fish and wildlife, in LaRoe, E.T., Farris, G.S., Puckett, C.E., Doran, P.D., and Mac, M.J., eds., Our living resources - a report to the Nation on the distribution, abundance, and health of U.S. plants, animals, and ecosystems: Washington, D.C., U.S. Department of the Interior, National Biological Service, 530 p. 
Schmitt, C.J., Dwyer, F.J., and Finger, S.E., 1984, Bioavailability of $\mathrm{Pb}$ and $\mathrm{Zn}$ from mine tailings as indicated by erythrocyte delta-aminolevulinic acid dehydratase (ALA-D) activity in suckers (Pisces: Catostomidae): Canadian Journal of Fisheries and Aquatic Sciences, v. 41, p. $1030-1040$.

Schmitt, C.J., Tillitt, D.E., and Kubiak, T.J., 1995, Biomonitoring of environmental status and trends (BEST) program - testing and implementation of selected aquatic ecosystem indicators in the Mississippi River system, 1995: National Biological Service, 10 p.

Schmitt, C.J., Zajicek, J.L., May, T.W., and Cowman, D.F., 1999, Organochlorine residues and elemental contaminants in U.S. freshwater fish, 1976-1986-national contaminant biomonitoring program: Reviews in Environmental Contamination and Toxicology, v. 162, p. 43-104.

Schmitt, C.J., Zajicek, J.L., and Peterman, P.H., 1990, National contaminant biomonitoring program-residues of organochlorine chemicals in U.S. freshwater fish, 1976-1984: Archives of Environmental Contamination and Toxicology, v. 19, p. 748-781.

Sevin, I.F., 1980, Nickel, in Waldron, H.A., ed., Metals in the environment: London, Academic Press, p. 263-291.

Smith, G.J., and Anders, V.P., 1989, Toxic effects of boron on mallard reproduction: Environmental Toxicology and Chemistry, v. 8, p. 943-950.

Smith, S.B., Donahue, A.P., Lipkin, R.J., Blazer, V.S., Schmitt, C.J., and Goede, R.W., 2002, Illustrated field guide for assessing external and internal anomalies in fish: U.S. Geological Survey Information and Technology Report 2002-0007, p. 1-46, last accessed March 25, 2007, at http:// www.cerc.usgs.gov/pubs/center/pdfDocs/ITR_2002_0007. $p d f$

Sorenson, E.M., 1991, Metal poisoning in fish: Boca Raton, Fla., CRC Press Inc., 374 p.

Stegeman, J.J., and Lech, J.J., 1991, Cytochrome P-450 monooxygenase systems in aquatic species-carcinogen metabolism and biomarkers for carcinogen and pollutant exposure: Environmental Health Perspectives, v. 90, p. 101-109.

Summers, K., 2001, National coastal condition report: U.S. Environmental Protection Agency Environmental Monitoring and Assessment Program Office of Water, last accessed April 25, 2008, at http://www.epa.gov/emap/html/ data/estuary/data/, 204 p.
Sutton, S.G., Bult, T.P., and Haedrich, R.L., 2000, Relationships among fat weight, body weight, water weight, and condition factors in wild Atlantic salmon parr: Transactions of the American Fisheries Society, v. 129, p. 527-538.

Swarzenski, C.M., Mize, S.V., Thompson, B.A., and Peterson, G.W., 2004, Fish and aquatic invertebrate communities in waterways, and contaminants in fish, at the Barataria Preserve of the Jean Lafitte National Historical Park and Preserve, Louisiana: U.S. Geological Survey Scientific Investigations Report 2004-5065, p. 1-35.

Thacker, P.D., 2006, Condors are full of lead: Environmental Science and Technology, v. 40, p. 5826.

Toft, G., Edwards, T.M., Baatrup, E., and Guillette, L.J., 2003, Disturbed sexual characteristics in male mosquitofish (Gambusia holbrooki) from a lake contaminated with endocrine disruptors: Environmental Health Perspectives, v. 111, p. 695-701.

U.S. Army Engineer District, 1995, Flood control of the Mississippi River and tributaries, Mississippi Delta region, Louisiana, salinity control structures, design memorandum no. 1-Davis Pond freshwater diversion structure, supplement no. 1-biological, hydrologic, water and sediment quality monitoring program: New Orleans, La., U.S. Army Corps of Engineers, New Orleans District, 50 p.

U.S. Environmental Protection Agency, 1980, Ambient water quality criteria document for mercury: Springfield, Va., National Technical Information Service, U.S. Environmental Protection Agency Report 440/5-80-058.

U.S. Environmental Protection Agency, 1993, Wildlife exposure factors handbook, v. I and v. II: Springfield, Va., U.S. Department of Commerce, National Technical Information Service.

U.S. Environmental Protection Agency, 1999, National recommended water quality criteria: Cincinnati, Ohio, National Center for Environmental Publications and Information, 25 p. accessed April 25, 2008, at http://www. epa.gov/waterscience/pc/1999table.pdf

U.S. Environmental Protection Agency, 2000, The USEPA Persistent, Bioaccumulative, and Toxic Pollutants (PBT) Pesticides Work Group: U.S. Environmental Protection Agency, Draft PBT national action plan for the level 1 pesticides, $107 \mathrm{p}$.

U.S. Environmental Protection Agency, 2002, National primary drinking water standards: U.S. Environmental Protection Agency, 816-F-02-013. 
U.S. Fish and Wildlife Service, 1983-89, Species profileslife histories and environmental requirements of coastal fishes and invertebrates: U.S. Fish and Wildlife Service Biological Report 82 (11), U.S. Army Corps of Engineers TR EL-82-4, last accessed April 28, 2008, at http://www. nwrc.usgs.gov:80/publications/specintro.htm

U.S. Geological Survey, 2007a, Contaminants exposure and effects - terrestrial vertebrates database: U.S. Geological Survey, last accessed April 25, 2008, at http://www.pwrc. usgs.gov/contaminants-online/

U.S. Geological Survey, 2007b, Biological and ecotoxicological characteristics of terrestrial vertebrate species residing in estuaries: U.S. Geological Survey, last accessed April 25, 2008, at http://www.pwrc.usgs.gov/ bioeco/baldeagl.htm

van Campenhout, K., Bervoets, L., and Blust, R., 2007, Assimilation efficiencies of $\mathrm{Cd}$ and $\mathrm{Zn}$ in the common carp (Cyprinus carpio) - effects of metal concentration, temperature and prey type: Environmental Pollution, v. 145, p. 905-914.

van der Oost, R., Beyer, J., and Vermeulen, N.P.E., 2003, Fish bioaccumulation and biomarkers in environmental risk assessment-a review: Environmental Toxicology and Pharmacology, v. 13, p. 148-166.

van der Weiden, M.E.J., Bleumink, R., Seinen, W., and van den Berg, M., 1994, Concurrence of P450 1A induction and toxic effects in the mirror carp (Cyprinus carpio), after administration of a low dose of 2,3,7,8-tetrachlorodibenzop-dioxin: Aquatic Toxicology, v. 29, p. 147-162.

Whyte, J.J., Jung, R.E., Schmitt, C.J., and Tillitt, D.E., 2000, Ethoxyresorufin-O-deethylase (EROD) activity in fish as a biomarker of chemical exposure: Boca Raton, Fla., CRC Press Inc., p. 347-350.

Wiemeyer, S.N., Bunck, C.M., and Stafford, C.J., 1993, Environmental contaminants in bald eagle eggs, 19801984, and further interpretations of relationships to productivity and shell thickness: Archives of Environmental Contamination and Toxicology, v. 24, p. 213-227.
Wiemeyer, S.N., Lamont, T.G., Bunck, C.M., Sindelar, C.R., Gramlick, F.J., Fraser, J.D., and Byrd, M.A., 1984, Organochlorine pesticide, polychlorobiphenyl, and mercury residues in bald eagle eggs - 1969-79_ and their relationships to shell thinning and reproduction: Archives of Environmental Contamination and Toxicology, v. 13, p. $529-549$.

Wiener, J.G., and Spry, D.J., 1996, Toxicological significance of mercury in freshwater fish, in Beyer, W.N., Heinz, G.H., and Redmon-Norwood, A.W., eds., Environmental contaminants in wildlife: Clemson, Lewis Publishers, p. 297-339.

Williams, M.L., Hothem, R.L., and Ohlendorf, H.M., 1989, Recruitment failure in American avocets and black-necked stilts nesting at Kesterson Reservoir, California, 1984-1985: The Condor, v. 91, p. 797-802.

Wolke, R.E., 1992, Piscine macrophage aggregates-a review: Annual Review of Fish Diseases, v. 2, p. 91-108.

Wu, S.M., and Deng, A.N., 2006, Effect of cadmium on hematological functions in tilapia (Oreochromis mossambicus): Bulletin of Environmental Contamination and Toxicology, v. 76, p. 891-898.

Zdanowicz, V., Gadbois, D., and Newman, M., 1986, Levels of organic and inorganic contaminants in sediments and fish tissues and prevalences of pathological disorders in winter flounder from estuaries of the Northeast United States, 1984, in Oceans ' 86 conference recordscience-engineering-adventure, v. 2, Data management, instrumentation, and economics: New York, Institute of Electrical and Electronics Engineers, p. 578-585.

Zugarramurdi, A., Parin, M.A., Gadaleta, L., Carrizo, G.A., Montecchia, C., Boeri, R.L., and Giannini, D.H., 2003, Seasonal variation in condition factor, gonadosomatic index and processing yield of carp (Cyprinus carpio): Journal of Aquatic Food Product Technology, v. 12, p. 33-45. 


\section{Appendix 1. Additional Tables and Figures}

Table 1-1. Fish collection dates and water-quality parameters at the time of sampling.

[Data are from the Louisiana Department of Wildlife and Fisheries]

\begin{tabular}{lccc}
\multicolumn{1}{c}{ Date } & Temperature $\left({ }^{\circ} \mathbf{C}\right)$ & Salinity (parts per thousand) & Conductivity (microsiemens/cm) \\
\hline January 9-10, 2001 & 17 & 2.6 & 4.84 \\
March 14, 2001 & 21 & 1.87 & 3.49 \\
May 8-9, 2001 & 27 & 1.41 & 2.75 \\
June 21, 2001 & 29 & 1.2 & 2.36 \\
\hline
\end{tabular}


Table 1-2. Fish health data and sampling dates.

[M, male; Fm, female; N, normal; S, scar; P, parasite; ME, mild erosion; Fr, frayed; T, tumors; L, lesions; E, empty; F, full; PF, partially full; Y, yellow; G, light green; GB, green to blue green; Rd-Bk, red to black; CAT, blue catfish (Ictalurus furcatus); LMB, largemouth bass (Micropterus salmoides); MUL, striped mullet (Mugil cephalus); CAMP, site at Lake Salvador; CATA, site at Lake Cataouatche; COUBA, site at Bayou Couba; MR, site at Mississippi River. * Spleen from this animal used in place of lost spleen of LMB33RIVER]

\begin{tabular}{|c|c|c|c|c|c|c|c|c|}
\hline Date & ID name & ID number & Weight (g) & Length $(\mathrm{cm})$ & Left eye & Right eye & Head & Body \\
\hline January 9, 2001 & CAT1CAMP & 34 & 4,668 & 82 & $\mathrm{~N}$ & $\mathrm{~N}$ & $\mathrm{~N}$ & $\mathrm{~N}$ \\
\hline January 9, 2001 & CAT2CAMP & 35 & 1,482 & 59 & $\mathrm{~N}$ & $\mathrm{~N}$ & $\mathrm{~N}$ & $\mathrm{~N}$ \\
\hline January 9, 2001 & САТЗСАMP & 36 & 2,354 & 69 & $\mathrm{~N}$ & $\mathrm{~N}$ & $\mathrm{~N}$ & $S$ \\
\hline January 9, 2001 & LMB4CAMP & 31 & 132 & 26 & $\mathrm{~N}$ & $\mathrm{~N}$ & $\mathrm{~L}$ & $S$ \\
\hline January 9, 2001 & LMB5CAMP & 32 & 118 & 24 & $\mathrm{~N}$ & $\mathrm{~N}$ & $\mathrm{~N}$ & $\mathrm{~N}, \mathrm{P}$ \\
\hline January 9, 2001 & LMB6CAMP & 33 & 520 & 39 & $\mathrm{~N}$ & $\mathrm{~N}$ & $\mathrm{~N}$ & $\mathrm{~N}$ \\
\hline March 14, 2001 & CAT7CATA & 16 & 1,036 & 451 & N, Red & N, Red & $\mathrm{N}$ & $S$ \\
\hline March 14, 2001 & LMBRIVER* & & 1,172 & 49 & $\mathrm{~N}$ & $\mathrm{~N}$ & $\mathrm{~N}$ & $\mathrm{~L}, \mathrm{~T}$ \\
\hline March 14, 2001 & LMB3COUBA & 23 & 142 & 23 & $\mathrm{~N}$ & $\mathrm{~N}$ & $\mathrm{~N}$ & $\mathrm{~N}$ \\
\hline March 14, 2001 & LMB10COUBA & 21 & 112 & 24 & $\mathrm{~N}$ & $\mathrm{~N}$ & $\mathrm{~N}$ & $\mathrm{~N}$ \\
\hline May 8, 2001 & LMB11COUBA & 22 & 78 & 22 & $\mathrm{~N}$ & $\mathrm{~N}$ & $\mathrm{~N}$ & $\mathrm{~T}$ \\
\hline May 8, 2001 & CAT12COUBA & 24 & 1,700 & 61 & $\mathrm{~N}$ & $\mathrm{~N}$ & $\mathrm{~N}$ & $\mathrm{~N}$ \\
\hline May 8, 2001 & CAT13COUBA & 25 & 1,516 & 62 & $\mathrm{~N}$ & $\mathrm{~N}$ & $\mathrm{~N}$ & $\mathrm{~N}$ \\
\hline May 8, 2001 & CAT14COUBA & 26 & 1,478 & 60 & $\mathrm{~N}$ & $\mathrm{~N}$ & $\mathrm{~N}$ & $\mathrm{~N}$ \\
\hline May 8, 2001 & MUL15CAMP & 37 & 119 & 26 & $\mathrm{~N}$ & $\mathrm{~N}$ & $\mathrm{~N}$ & $\mathrm{~N}$ \\
\hline May 8, 2001 & MUL16CAMP & 38 & 196 & 32 & $\mathrm{~N}$ & $\mathrm{~N}$ & $\mathrm{~N}$ & $\mathrm{~N}$ \\
\hline May 8, 2001 & MUL17CAMP & 39 & 166 & 31 & $\mathrm{~N}$ & $\mathrm{~N}$ & $\mathrm{~N}$ & $\mathrm{~N}$ \\
\hline May 8, 2001 & MUL18CATA & 17 & 275 & 34 & $\mathrm{~N}$ & $\mathrm{~N}$ & $\mathrm{~N}$ & $\mathrm{~N}$ \\
\hline May 8, 2001 & MUL19CATA & 18 & 318 & 38 & $\mathrm{~N}$ & $\mathrm{~N}$ & $\mathrm{~N}$ & $\mathrm{~N}$ \\
\hline May 8, 2001 & MUL20CATA & 19 & 325 & 31 & $\mathrm{~N}$ & $\mathrm{~N}$ & $\mathrm{~N}$ & $\mathrm{~N}$ \\
\hline May 8, 2001 & LMB21CATA & 11 & 248 & 26 & $\mathrm{~N}$ & $\mathrm{~N}$ & $\mathrm{~N}$ & $\mathrm{~N}$ \\
\hline May 8, 2001 & CAT22CATA & 14 & 1,942 & 57 & $\mathrm{~N}$ & $\mathrm{~N}$ & $\mathrm{~N}$ & $\mathrm{~N}$ \\
\hline May 8, 2001 & CAT23CATA & 15 & 3,176 & 66 & $\mathrm{~N}$ & $\mathrm{~N}$ & $\mathrm{~N}$ & $\mathrm{~N}$ \\
\hline May 8, 2001 & LMB24CATA & 12 & 192 & 28 & $\mathrm{~N}$ & $\mathrm{~N}$ & $\mathrm{~N}$ & $\mathrm{~N}$ \\
\hline May 8, 2001 & LMB25CATA & 13 & 130 & 36 & $\mathrm{~N}$ & $\mathrm{~N}$ & $\mathrm{~N}$ & $\mathrm{~N}$ \\
\hline May 8, 2001 & MUL26COUBA & 27 & 205 & 31 & $\mathrm{~N}$ & $\mathrm{~N}$ & $\mathrm{~N}$ & $\mathrm{~N}$ \\
\hline May 8, 2001 & MUL27COUBA & 28 & 278 & 28 & $\mathrm{~N}$ & $\mathrm{~N}$ & $\mathrm{~N}$ & $\mathrm{~N}$ \\
\hline May 8, 2001 & MUL28COUBA & 29 & 232 & 28 & $\mathrm{~N}$ & $\mathrm{~N}$ & $\mathrm{~N}$ & $\mathrm{~N}$ \\
\hline May 23, 2001 & MUL30RIVER & 7 & 176 & 26 & $\mathrm{~N}$ & $\mathrm{~N}$ & $\mathrm{~N}$ & $\mathrm{~N}$ \\
\hline May 23, 2001 & MUL31RIVER & 8 & 316 & 34 & $\mathrm{~N}$ & $\mathrm{~N}$ & $\mathrm{~N}$ & $\mathrm{~S}, \mathrm{P}$ \\
\hline May 23, 2001 & MUL32RIVER & 9 & 452 & 39 & $\mathrm{~N}$ & $\mathrm{~N}$ & $\mathrm{~N}$ & $\mathrm{~N}$ \\
\hline May 23, 2001 & LMB33RIVER & 1 & 122 & 21 & $\mathrm{~N}$ & $\mathrm{~N}$ & $\mathrm{~N}$ & $\mathrm{~N}$ \\
\hline May 23, 2001 & LMB34RIVER & 2 & 394 & 32 & $\mathrm{~N}$ & $\mathrm{~N}$ & $\mathrm{~N}$ & $\mathrm{~N}$ \\
\hline May 23, 2001 & LMB35RIVER & 3 & 384 & 30 & $\mathrm{~N}$ & $\mathrm{~N}$ & $\mathrm{~N}$ & $\mathrm{~N}$ \\
\hline June 21, 2001 & CAT36RIVER & 4 & 58 & 19 & $\mathrm{~N}$ & $\mathrm{~N}$ & $\mathrm{~N}$ & $\mathrm{~N}$ \\
\hline June 21, 2001 & CAT37RIVER & 5 & 12.46 & 12 & $\mathrm{~N}$ & $\mathrm{~N}$ & $\mathrm{~N}$ & $\mathrm{~N}$ \\
\hline June 21, 2001 & CAT38RIVER & 6 & 1,600 & 73 & $\mathrm{~N}$ & $\mathrm{~N}$ & $\mathrm{~S}$ & $\mathrm{~L}$ \\
\hline
\end{tabular}




\begin{tabular}{|c|c|c|c|c|c|c|c|c|c|}
\hline Opercles & Gills & Fins & Liver & Liver weight (g) & Bile & Spleen & Spleen weight (g) & Sex by gonads & Notes \\
\hline $\mathrm{N}$ & $\mathrm{N}$ & $\mathrm{N}$ & Dark red & 108.0 & $\mathrm{~F}, \mathrm{Y}$ & n.d. & n.d. & M & \\
\hline $\mathrm{N}$ & $\mathrm{N}$ & $\mathrm{N}$ & Dark red & 37.8 & $\mathrm{~F}, \mathrm{Y}$ & Rd-Bk & 2.95 & M & \\
\hline $\mathrm{N}$ & $\mathrm{N}$ & $\mathrm{N}$ & Dark red & 2.0 & $\mathrm{~F}, \mathrm{Y}$ & Rd-Bk & 0.29 & $\mathrm{Fm}$ & \\
\hline $\mathrm{N}$ & $\mathrm{N}, \mathrm{P}$ & $\mathrm{N}$ & Dark red & 3.0 & $\mathrm{~F}, \mathrm{Y}$ & Rd-Bk & 1.00 & $\mathrm{Fm}$ & \\
\hline $\mathrm{N}$ & $\mathrm{N}$ & $\mathrm{N}$ & Dark red & 11.4 & $\mathrm{~F}, \mathrm{Y}$ & Rd-Bk & 1.13 & M & \\
\hline $\mathrm{N}$ & $\mathrm{N}$ & $\mathrm{N}$ & Dark red & 17.7 & $\mathrm{~F}, \mathrm{Y}$ & Rd-Bk & 1.07 & M & \\
\hline $\mathrm{N}$ & $\mathrm{N}$ & $\mathrm{N}$ & Dark red & 1.9 & $\mathrm{~F}, \mathrm{Y}$ & $\mathrm{Rd}-\mathrm{Bk}$ & 0.09 & Fm Ripe & \\
\hline $\mathrm{N}$ & $\mathrm{N}$ & $\mathrm{N}$ & Dark red & 1.7 & $\mathrm{E}$ & Rd-Bk & 0.40 & $\mathrm{Fm}$ & \\
\hline $\mathrm{N}$ & $\mathrm{N}$ & $\mathrm{N}$ & Tan & 22.2 & $\mathrm{~F}, \mathrm{Y}$ & Rd-Bk & 2.60 & M & \\
\hline $\mathrm{N}$ & $\mathrm{N}$ & $\mathrm{N}$ & Tan & 1.2 & $\mathrm{E}$ & $\mathrm{Rd}-\mathrm{Bk}$ & 0.12 & n.d. & \\
\hline $\mathrm{N}$ & $\mathrm{N}, \mathrm{P}$ & $\mathrm{N}$ & Dark red & 3.4 & $\mathrm{E}$ & Rd-Bk & 0.52 & $\mathrm{Fm}$ & \\
\hline $\mathrm{N}$ & $\mathrm{N}, \mathrm{P}$ & $\mathrm{N}$ & Dark red & 2.8 & $\mathrm{~F}, \mathrm{Y}$ & Rd-Bk & 0.40 & $\mathrm{Fm}$ & \\
\hline $\mathrm{N}$ & $\mathrm{N}$ & $\mathrm{N}$ & Tan & 6.0 & PF, G & $\mathrm{Rd}-\mathrm{Bk}$ & 0.67 & $\mathrm{Fm}$ & \\
\hline $\mathrm{N}$ & $\mathrm{N}$ & $\mathrm{N}$ & Tan & 7.9 & PF, G & Rd-Bk & 1.46 & M & \\
\hline $\mathrm{N}$ & $\mathrm{N}, \mathrm{P}$ & $\mathrm{N}$ & Tan & 4.6 & $\mathrm{E}$ & Rd-Bk & 0.43 & M & \\
\hline $\mathrm{N}$ & $\mathrm{N}$ & $\mathrm{N}$ & Tan & 2.2 & E & $\mathrm{Rd}-\mathrm{Bk}$ & 0.29 & $\mathrm{Fm}$ & \\
\hline $\mathrm{N}$ & $\mathrm{N}$ & $\mathrm{N}$ & Tan & 2.8 & PF, Y & Rd-Bk & 0.41 & M & \\
\hline $\mathrm{N}$ & $\mathrm{N}, \mathrm{P}$ & $\mathrm{ME}$ & Tan & 3.5 & PF, G & Rd-Bk & 0.30 & M & \\
\hline $\mathrm{N}$ & $\mathrm{N}, \mathrm{P}$ & $\mathrm{N}, \mathrm{Fr}$ & Tan & 4.7 & PF, Y & Rd-Bk & 0.75 & $\mathrm{Fm}$ & \\
\hline $\mathrm{N}$ & $\mathrm{N}, \mathrm{P}$ & $\mathrm{N}$ & Tan & 9.3 & PF, Y & Rd-Bk & 1.43 & $\mathrm{Fm}$ & \\
\hline $\mathrm{N}$ & $\mathrm{N}$ & $\mathrm{N}$ & Tan & 0.8 & PF, Y & Rd-Bk & n.d. & n.d. & \\
\hline $\mathrm{N}$ & $\mathrm{N}$ & $\mathrm{N}$ & Tan & 4.2 & $\mathrm{E}$ & $\mathrm{Rd}-\mathrm{Bk}$ & 0.36 & Fm Ripe & \\
\hline $\mathrm{N}$ & $\mathrm{N}$ & $\mathrm{N}$ & Tan & 2.3 & $\mathrm{~F}, \mathrm{Y}$ & Rd-Bk & 0.27 & M & \\
\hline $\mathrm{N}$ & $\mathrm{N}$ & $\mathrm{N}$ & Dark red & 0.9 & PF, Y & $\mathrm{Rd}-\mathrm{Bk}$ & 0.06 & $\mathrm{Fm}$ & \\
\hline $\mathrm{N}$ & $\mathrm{N}$ & $\mathrm{N}$ & Dark red & 0.2 & PF, Y & Rd-Bk & $>0.001$ & Indeterminate & \\
\hline $\mathrm{N}$ & $\mathrm{N}$ & $\mathrm{N}$ & Dark red & 41.5 & $\mathrm{~F}, \mathrm{Y}$ & Rd-Bk & 9.00 & M & \\
\hline
\end{tabular}


Table 1-3. Eagle nest numbers, site locations, number of eaglets bled, and corresponding blood sample and banding identification numbers.

[Birds with "S" in ID were bled on February 14, 2001, and "H" birds were bled on February 20 or 21, 2001]

\begin{tabular}{|c|c|c|c|c|c|c|c|}
\hline Nest ID & Site location & Eaglets bled & Sample ID & Band ID & Latitude & Longitude & Parish \\
\hline 27 & $\begin{array}{l}\text { Salvador State } \\
\text { Wildlife } \\
\text { Management } \\
\text { Area }\end{array}$ & 2 of 2 & S156 and S157 & 156,157 & 29.88970 & -90.29060 & St. Charles \\
\hline 12 & $\begin{array}{l}\text { Salvador State } \\
\text { Wildlife } \\
\text { Management } \\
\text { Area }\end{array}$ & 1 of 1 & S158 & 158 & 29.86060 & -90.29140 & St. Charles \\
\hline 87 & $\begin{array}{l}\text { Mile } 75 \text { of } \\
\text { Intracoastal } \\
\text { Waterway }\end{array}$ & 1 of 2 & H169 & 168,169 & 29.61617 & -90.96867 & Terrebonne \\
\hline 129 & $\begin{array}{l}\text { Savanna Rd., } \\
\text { Houma }\end{array}$ & 1 of 2 & H160 & 160 & 29.62983 & -90.77433 & Terrebonne \\
\hline 53 & $\begin{array}{l}\text { Houma, } \\
\text { Intracoastal } \\
\text { Waterway }\end{array}$ & 1 of 1 & H159 & 159 & 29.53183 & -90.74600 & Terrebonne \\
\hline
\end{tabular}

Table 1-4. Historical nest activity (1991-2001) and estimates of numbers of eaglets fledged (1997-2001) at the same nests sampled during the current study near Davis Pond, February 2001.

[Data were obtained from the Louisiana Department of Wildlife and Fisheries (LDWF)]

\begin{tabular}{lccc}
\hline LDWF nest ID & Years of monitoring & Years of activity & Number of eaglets fledged since 1997 \\
\hline 107 & 10 & 9 & 7 \\
188 & 6 & 6 & 9 \\
154 (reference) & 8 & 7 & 7 \\
085 (reference) & 11 & 11 & 6 \\
108 (reference) & 10 & 8 & 7 \\
\hline
\end{tabular}


$\square$ LMB $\square$ CAT $\square$ MUL

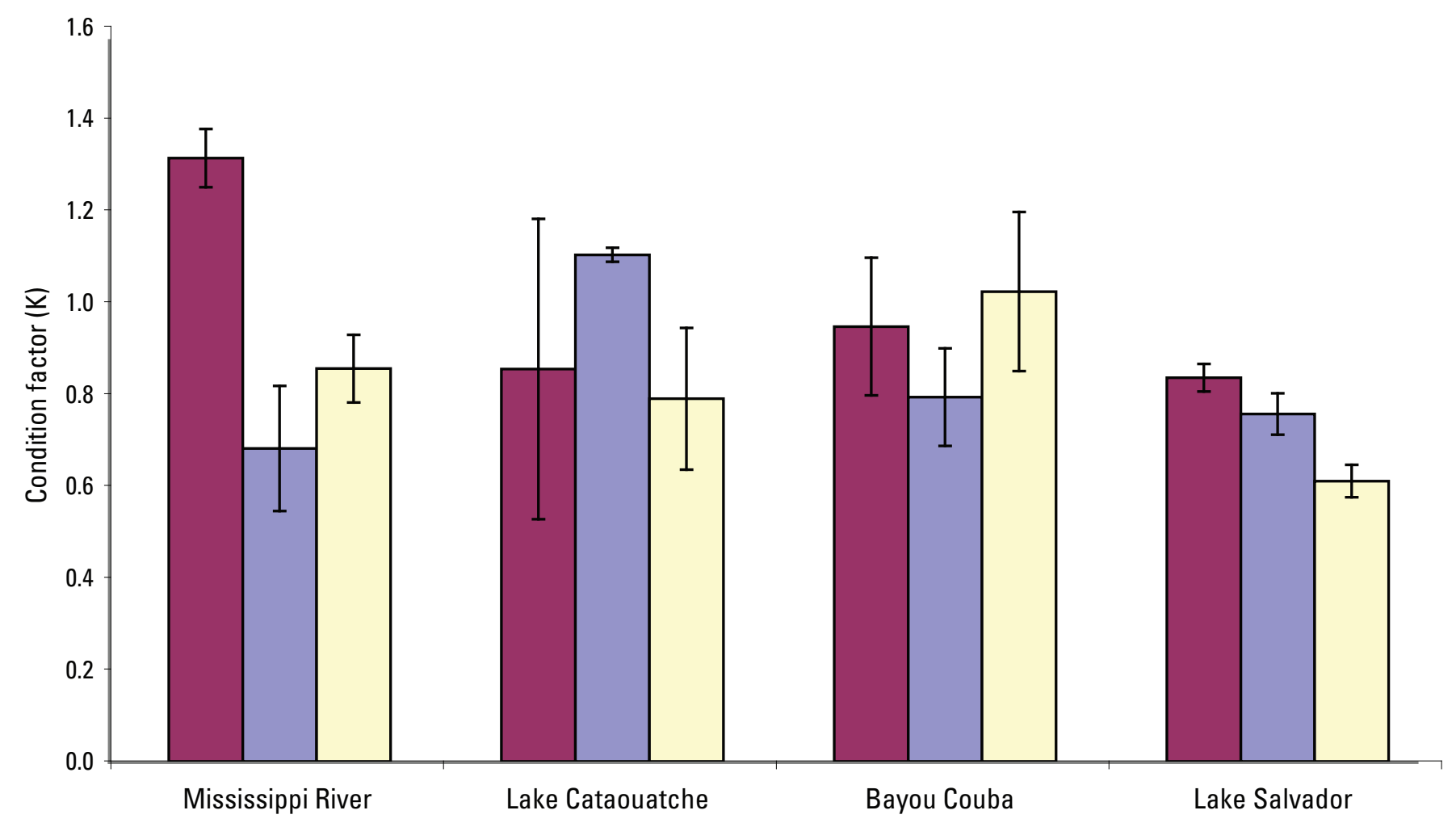

Figure 1-1. Condition factor ( \pm standard error) of largemouth bass (LMB), blue catfish (CAT), and striped mullet (MUL) collected at sites in southeastern Louisiana from January through June 2001. 


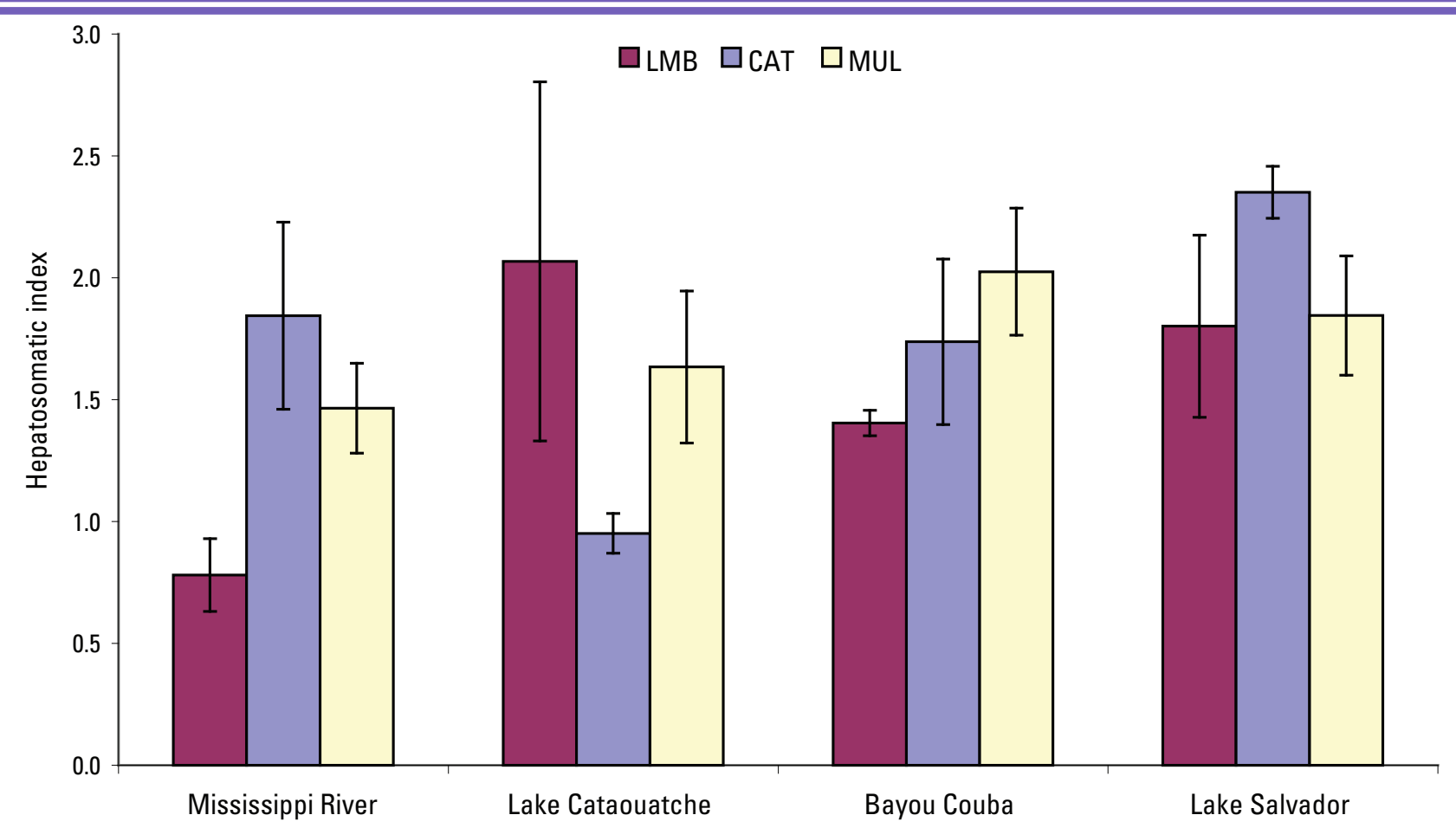

Figure 1-2. Hepatosomatic indices (HSI; liver weight/body weight $\times 100$ ) ( \pm standard error) of largemouth bass (LMB), blue catfish (CAT), and striped mullet (MUL) collected at sites in southeastern Louisiana from January through June 2001. Catfish had significantly lower HSI at Lake Cataouatche than did the other two species $(P<0.0217)$; however, males and females collected at different seasons were compared, and HSI can be influenced by breeding condition, nutrition, and sex. Trends were noted. The HSI of largemouth bass at the Mississippi River and for catfish at Lake Cataouatche were lower than the HSI for all species at the other sites. For catfish, the HSI was significantly lower at Lake Cataouatche than at the other sites.

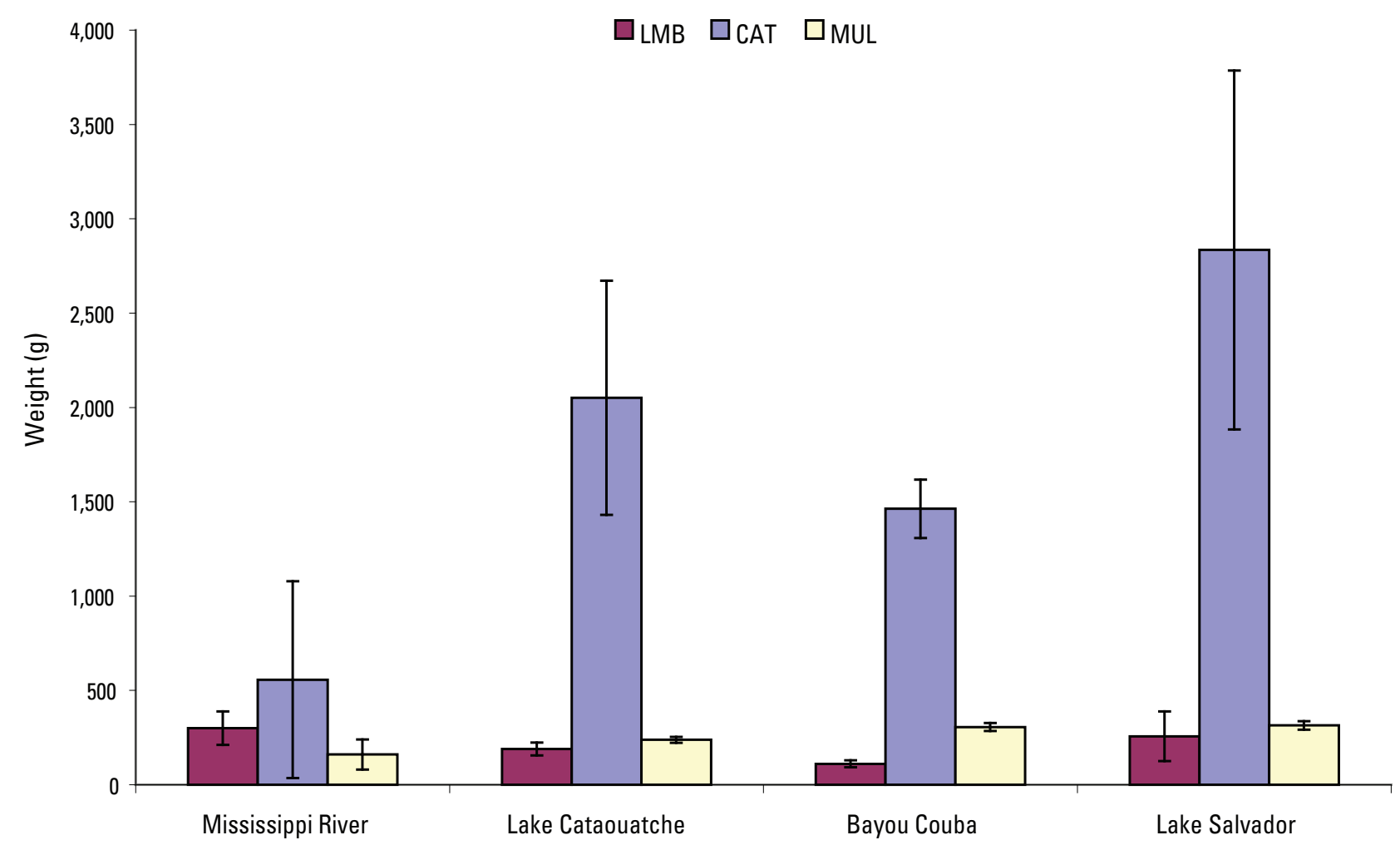

Figure 1-3. Average body weights ( \pm standard error) of largemouth bass (LMB), blue catfish (CAT), and striped mullet (MUL) collected at sites in southeastern Louisiana from January through June 2001. 


\begin{tabular}{|c|c|}
\hline \multicolumn{2}{|c|}{$\begin{array}{l}\text { [Compounds that are reasonably expected to be human carcinogens are } \\
\text { presented in boldface type (National Toxicology Program, 2002)] }\end{array}$} \\
\hline naphthalene & 1,2,5,6-dibenzanthracene \\
\hline 2-methylnaphthalene & benzo(g,h,i)perylene \\
\hline 1-methylnaphthalene & C1-naphthalenes \\
\hline biphenyl & C2-naphthalenes \\
\hline 2,6-dimethylnaphthalene & C3-naphthalenes \\
\hline acenaphthalene & C4-naphthalenes \\
\hline acenaphthene & C1-fluorenes \\
\hline 2,3,5-trimethylnaphthalene & C2-fluorenes \\
\hline fluorene & C3-fluorenes \\
\hline dibenzothiophene & C1-phenanthrenes \\
\hline phenanthrene & C2-phenanthrenes \\
\hline anthracene & C3-phenanthrenes \\
\hline 1-methylphenanthrene & C4-phenanthrenes \\
\hline fluoranthene & C1-dibenzothiophenes \\
\hline pyrene & C2-dibenzothiophenes \\
\hline 1,2-benzanthracene & C3-dibenzothiophenes \\
\hline chrysene & C1-fluoranthenes+C1-pyrene \\
\hline benzo(b)fluoranthene & C1-chrysenes \\
\hline benzo(k)fluoranthene & C2-chrysenes \\
\hline benzo(e)pyrene & C3-chrysenes \\
\hline benzo(a)pyrene & C4-chrysenes \\
\hline perylene & \\
\hline indeno(1,2,3-cd)pyrene & \\
\hline
\end{tabular}


Table 1-6. Polycyclic aromatic hydrocarbon (PAH) concentration (parts per million wet weight) per aquatic animal collected for the Davis Pond prediversion biomonitoring survey, January through June 2001. Quality control of data checked by the U.S. Fish and Wildlife Service Analytical Control Facility.

[Dots represent concentrations that were below detectable levels]

Sample ID

\section{LMB33RIVER LMB34RIVER LMB35RIVER CAT38RIVER CAT36RIVER CAT37RIVER MUL3ORIVER}

PAHs

naphthalene

0.012

2-methylnaphthalene

0.011

1-methylnaphthalene

biphenyl

0.012

2,6-dimethylnaphthalene

0.014

acenaphthalene

acenaphthene

0.014

2,3,5-trimethylnaphthalene

$\begin{array}{ll}\cdot & 0.028 \\ 0.014 & 0.01\end{array}$

dibenzothiophene

phenanthrene

0.022

0.025

0.01

0.018

anthracene

1-methylphenanthrene

0.02

fluoranthene

pyrene

1,2-benzanthracene

chrysene

benzo(b)fluoranthene

benzo(k)fluoranthene

benzo(e)pyrene

benzo(a)pyrene

perylene

indeno(1,2,3-cd)pyrene

1,2,5,6-dibenzanthracene

benzo(g,h,i)perylene

C1-naphthalenes

C2-naphthalenes

C3-naphthalenes

C4-naphthalenes

C1-fluorenes

C2-fluorenes

C3-fluorenes

C1-phenanthrenes

C2-phenanthrenes

C3-phenanthrenes

C4-phenanthrenes

C1-dibenzothiophenes

C2-dibenzothiophenes 
Sample ID

LMB33RIVER LMB34RIVER LMB35RIVER CAT38RIVER CAT36RIVER CAT37RIVER MUL30RIVER

C3-dibenzothiophenes

C1-fluoranthenes+C1-pyrene

C1-chrysenes

C2-chrysenes

C3-chrysenes

C4-chrysenes

Total PAHs
0.029
0.102

0.258
0.114

0.186 
Table 1-6. Polycyclic aromatic hydrocarbon (PAH) concentration (parts per million wet weight) per aquatic animal collected for the Davis Pond prediversion biomonitoring survey, January through June 2001. Quality control of data checked by the U.S. Fish and Wildlife Service Analytical Control Facility.-Continued

[Dots represent concentrations that were below detectable levels]

Sample ID

\begin{tabular}{l}
\hline PAHs \\
naphthalene \\
2-methylnaphthalene \\
1-methylnaphthalene \\
biphenyl \\
2,6-dimethylnaphthalene \\
acenaphthalene \\
acenaphthene
\end{tabular}

2,3,5-trimethylnaphthalene

fluorene

0.1

dibenzothiophene

phenanthrene

0.14

0.038

0.14

0.012

anthracene

0.031

0.029

1-methylphenanthrene

0.015

fluoranthene

0.15

0.034

0.11

pyrene

0.13

0.032

0.067

1,2-benzanthracene

0.11

0.029

0.018

chrysene

0.13

0.038

0.024

benzo(b)fluoranthene

0.15

0.018

benzo(k)fluoranthene

0.027

0.014

benzo(e)pyrene

0.18

0.026

benzo(a)pyrene

0.08

0.11

0.039

0.028

0.015

0.02

0.029

0.028

0.023

perylene

0.019

0.016

0.031

0.016

0.013

indeno(1,2,3-cd)pyrene

0.083

0.029

0.016

1,2,5,6-dibenzanthracene

0.067

0.022

0.011

0.024

0.021

benzo(g,h,i)perylene

0.075

0.022

C1-naphthalenes

C2-naphthalenes

C3-naphthalenes

C4-naphthalenes

C1-fluorenes

C2-fluorenes

C3-fluorenes

C1-phenanthrenes

C2-phenanthrenes

C3-phenanthrenes

C4-phenanthrenes

C1-dibenzothiophenes

C2-dibenzothiophenes 
Sample ID

MUL31RIVER MUL32RIVER LMB21CATA LMB24CATA LMB25CATA CAT22CATA CAT23CATA

C3-dibenzothiophenes

C1-fluoranthenes+C1-pyrene

C1-chrysenes

C2-chrysenes

C3-chrysenes

C4-chrysenes

Total PAHs

1.598

0.366

0.064

0.443

0.112

0.065

0.036 
Table 1-6. Polycyclic aromatic hydrocarbon (PAH) concentration (parts per million wet weight) per aquatic animal collected for the Davis Pond prediversion biomonitoring survey, January through June 2001. Quality control of data checked by the U.S. Fish and Wildlife Service Analytical Control Facility.-Continued

[Dots represent concentrations that were below detectable levels]

Sample ID

\section{CAT7CATA MUL18CATA MUL19CATA MUL20CATA LMB10COUBA LMB11COUBA LMB3COUBA}

\section{PAHs}

naphthalene

0.011

0.01

2-methylnaphthalene

1-methylnaphthalene

biphenyl

2,6-dimethylnaphthalene

acenaphthalene

acenaphthene

2,3,5-trimethylnaphthalene

fluorene

dibenzothiophene

phenanthrene

0.015

0.013

0.01

anthracene

1-methylphenanthrene

fluoranthene

pyrene

1,2-benzanthracene

chrysene

benzo(b)fluoranthene

benzo(k)fluoranthene

0.014

0.012

0.015

benzo(e)pyrene

benzo(a)pyrene

0.022

0.018

0.018

0.013

0.017

0.019

0.059

0.058

0.024

perylene

0.016

0.017

0.017

0.016

indeno(1,2,3-cd)pyrene

1,2,5,6-dibenzanthracene

0.014

0.029

0.016

benzo(g,h,i)perylene

C1-naphthalenes

C2-naphthalenes

C3-naphthalenes

C4-naphthalenes

C1-fluorenes

C2-fluorenes

C3-fluorenes

C1-phenanthrenes

C2-phenanthrenes

C3-phenanthrenes

C4-phenanthrenes

C1-dibenzothiophenes

C2-dibenzothiophenes 
Sample ID

CAT7CATA MUL18CATA MUL19CATA MUL20CATA LMB10COUBA LMB11COUBA LMB3COUBA

C3-dibenzothiophenes

C1-fluoranthenes+C1-pyrene

C1-chrysenes

C2-chrysenes

C3-chrysenes

C4-chrysenes

Total PAHs
0.038
0.035

0.059
0.061 
Table 1-6. Polycyclic aromatic hydrocarbon (PAH) concentration (parts per million wet weight) per aquatic animal collected for the Davis Pond prediversion biomonitoring survey, January through June 2001. Quality control of data checked by the U.S. Fish and Wildlife Service Analytical Control Facility.-Continued

[Dots represent concentrations that were below detectable levels]

Sample ID

CAT12COUBA CAT13COUBA CAT14COUBA MUL26COUBA MUL27COUBA MUL28COUBA LMB4CAMP

\section{PAHs}

naphthalene

2-methylnaphthalene

1-methylnaphthalene

biphenyl

2,6-dimethylnaphthalene

acenaphthalene

acenaphthene

2,3,5-trimethylnaphthalene

fluorene

dibenzothiophene

phenanthrene

0.011

anthracene

1-methylphenanthrene

fluoranthene

pyrene

1,2-benzanthracene

chrysene

benzo(b)fluoranthene

benzo(k)fluoranthene

0.046

benzo(e)pyrene

benzo(a)pyrene

0.02

0.021

0.015

0.021

perylene

indeno(1,2,3-cd)pyrene

0.019

1,2,5,6-dibenzanthracene

benzo(g,h,i)perylene

C1-naphthalenes

C2-naphthalenes

C3-naphthalenes

C4-naphthalenes

C1-fluorenes

C2-fluorenes

C3-fluorenes

C1-phenanthrenes

C2-phenanthrenes

C3-phenanthrenes

C4-phenanthrenes

C1-dibenzothiophenes

C2-dibenzothiophenes 
C3-dibenzothiophenes

C1-fluoranthenes+C1-pyrene

C1-chrysenes

C2-chrysenes

C3-chrysenes

C4-chrysenes

Total PAHs
0.115
0.031

0.04
0.028

0.039 
Table 1-6. Polycyclic aromatic hydrocarbon (PAH) concentration (parts per million wet weight) per aquatic animal collected for the Davis Pond prediversion biomonitoring survey, January through June 2001. Quality control of data checked by the U.S. Fish and Wildlife Service Analytical Control Facility.-Continued

[Dots represent concentrations that were below detectable levels]

Sample ID

LMB5CAMP LMB6CAMP CAT1CAMP CAT2CAMP CAT3CAMP MUL15CAMP MUL16CAMP

\section{PAHs}

naphthalene

2-methylnaphthalene

1-methylnaphthalene

biphenyl

2,6-dimethylnaphthalene

acenaphthalene

acenaphthene

2,3,5-trimethylnaphthalene

fluorene

dibenzothiophene

phenanthrene

anthracene

1-methylphenanthrene

fluoranthene

pyrene

1,2-benzanthracene

chrysene

benzo(b)fluoranthene

benzo(k)fluoranthene

benzo(e)pyrene

benzo(a)pyrene

0.53

0.11

\section{CATICAMP}

perylene

indeno(1,2,3-cd)pyrene

0.013

0.012

0.021

1,2,5,6-dibenzanthracene

$$
\text { . }
$$

benzo(g,h,i)perylene

C1-naphthalenes

C2-naphthalenes

C3-naphthalenes

C4-naphthalenes

C1-fluorenes

C2-fluorenes

C3-fluorenes

C1-phenanthrenes

C2-phenanthrenes

C3-phenanthrenes

C4-phenanthrenes

C1-dibenzothiophenes

C2-dibenzothiophenes 
Sample ID

LMB5CAMP LMB6CAMP CAT1CAMP CAT2CAMP CAT3CAMP MUL15CAMP MUL16CAMP

C3-dibenzothiophenes

C1-fluoranthenes+C1-pyrene

C1-chrysenes

C2-chrysenes

C3-chrysenes

C4-chrysenes

Total PAHs
0.597

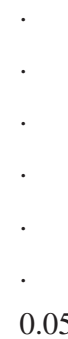

0.058
0.076

0.049
0.257 
Table 1-6. Polycyclic aromatic hydrocarbon (PAH) concentration (parts per million wet weight) per aquatic animal collected for the Davis Pond prediversion biomonitoring survey, January through June 2001. Quality control of data checked by the U.S. Fish and Wildlife Service Analytical Control Facility.-Continued

[Dots represent concentrations that were below detectable levels]

Sample ID

MUL17CAMP MUSSCATA MUSSCOUBA MUSSCAMP MUSSRIVER

\section{PAHs}

naphthalene

0.021

2-methylnaphthalene

1-methylnaphthalene

0.026

biphenyl

0.017

2,6-dimethylnaphthalene

acenaphthalene

0.013

0.032

acenaphthene

0.008

0.151

2,3,5-trimethylnaphthalene

0.019

fluorene

0.261

dibenzothiophene

0.064

phenanthrene

anthracene

0.3

1-methylphenanthrene

0.078

fluoranthene

2.53

pyrene

2.12

1,2-benzanthracene

0.993

chrysene

1.24

benzo(b)fluoranthene

0.982

benzo(k)fluoranthene

benzo(e)pyrene

0.593

benzo(a)pyrene

0.016

0.024

0.714

perylene

0.951

0.24

indeno(1,2,3-cd)pyrene

1,2,5,6-dibenzanthracene

benzo(g,h,i)perylene

C1-naphthalenes

C2-naphthalenes

C3-naphthalenes

0.104

0.088

C4-naphthalenes

0.26

C1-fluorenes

C2-fluorenes

C3-fluorenes

C1-phenanthrenes

C2-phenanthrenes

C3-phenanthrenes

C4-phenanthrenes

C1-dibenzothiophenes

C2-dibenzothiophenes 
Sample ID

MUL17CAMP MUSSCATA MUSSCOUBA MUSSCAMP MUSSRIVER

C3-dibenzothiophenes

C1-fluoranthenes+C1-pyrene

C1-chrysenes

C2-chrysenes

C3-chrysenes

C4-chrysenes

Total PAHs

0.049

0.056

0.02

0.658

0.697

0.045

17.534 
Table 1-7. Aliphatic hydrocarbon (AH) concentrations ( $\mu \mathrm{g} / \mathrm{g}$, wet weight) per aquatic animal collected for the Davis Pond prediversion biomonitoring survey, January through June 2001. Quality control of data checked by the U.S. Fish and Wildlife Service Analytical Control Facility.

[Dots represent concentrations that were below detectable levels]

Sample ID

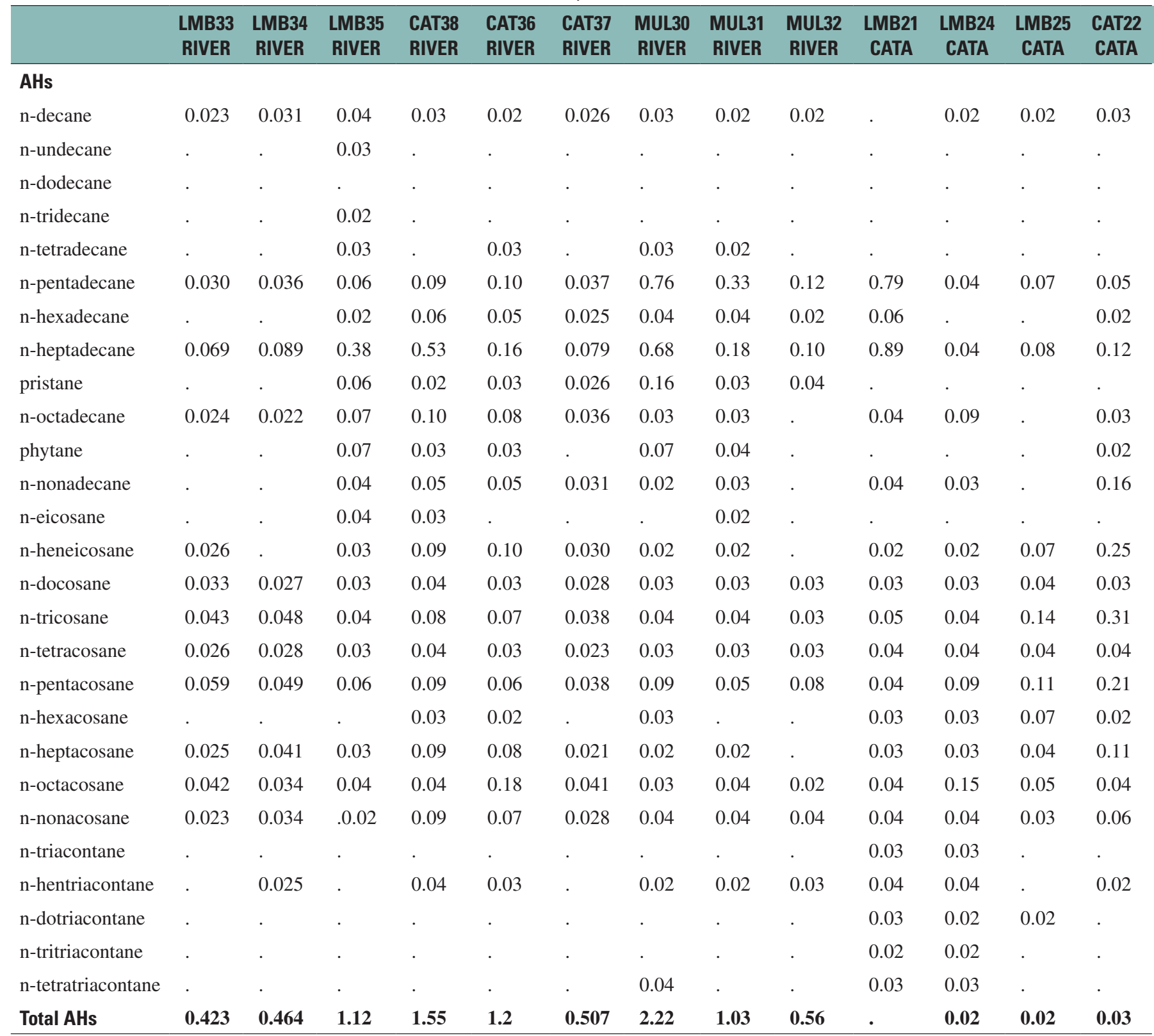




\section{Sample ID}

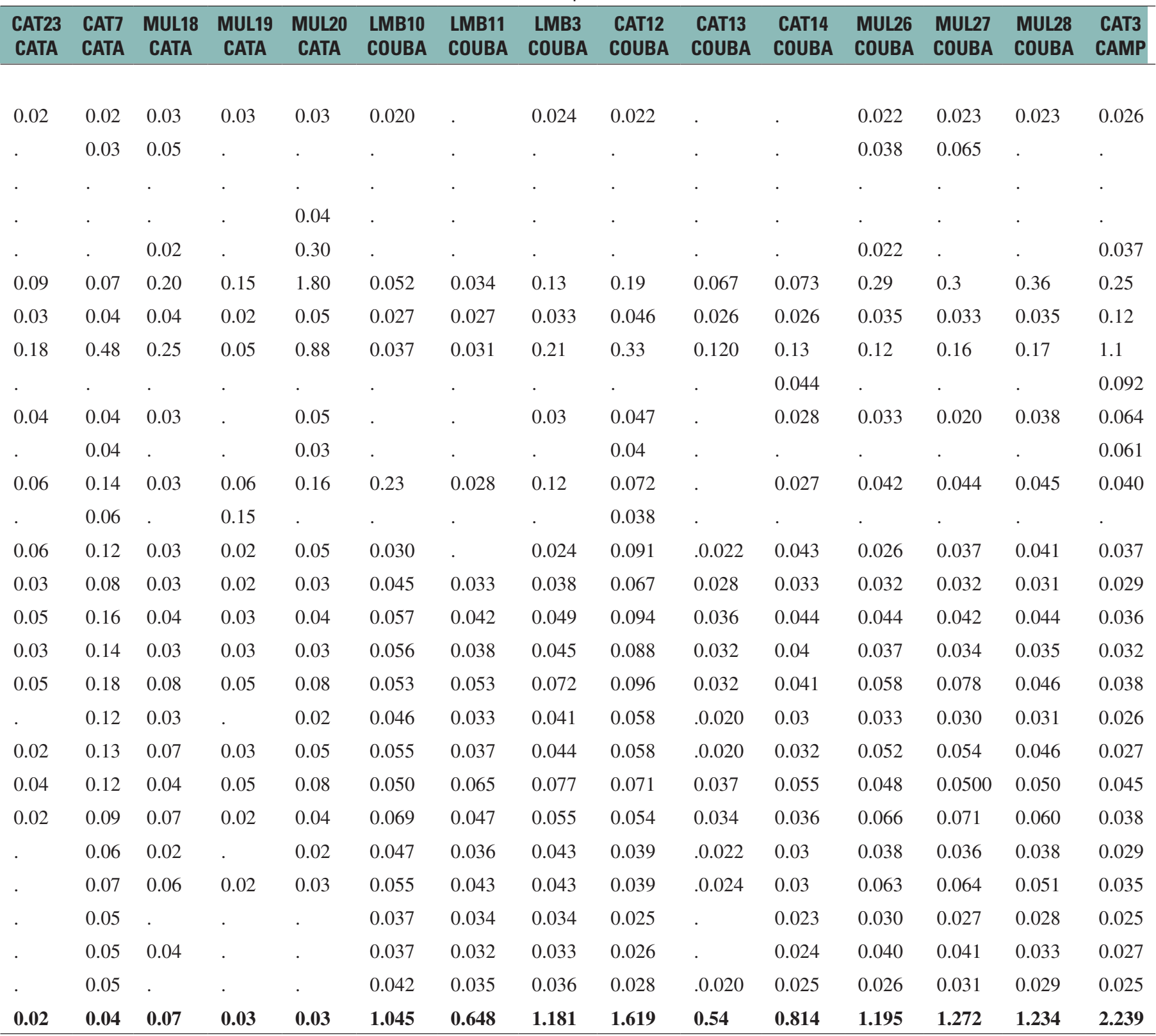


Table 1-7. Aliphatic hydrocarbon (AH) concentrations ( $\mu \mathrm{g} / \mathrm{g}$, wet weight) per aquatic animal collected for the Davis Pond prediversion biomonitoring survey, January through June 2001. Quality control of data checked by the U.S. Fish and Wildlife Service Analytical Control Facility.-Continued

[Dots represent concentrations that were below detectable levels]

Sample ID

\begin{tabular}{|c|c|c|c|c|c|c|c|c|c|c|c|c|}
\hline & $\begin{array}{l}\text { MUL15 } \\
\text { CAMP }\end{array}$ & $\begin{array}{l}\text { MUL16 } \\
\text { CAMP }\end{array}$ & $\begin{array}{l}\text { MUL17 } \\
\text { CAMP }\end{array}$ & $\begin{array}{l}\text { LMB4 } \\
\text { CAMP }\end{array}$ & $\begin{array}{l}\text { LMB5 } \\
\text { CAMP }\end{array}$ & $\begin{array}{l}\text { LMB6 } \\
\text { CAMP }\end{array}$ & $\begin{array}{l}\text { CAT1 } \\
\text { CAMP }\end{array}$ & $\begin{array}{l}\text { CAT2 } \\
\text { CAMP }\end{array}$ & $\begin{array}{l}\text { MUSS } \\
\text { CATA }\end{array}$ & $\begin{array}{l}\text { MUSS } \\
\text { COUBA }\end{array}$ & $\begin{array}{l}\text { MUSS } \\
\text { CAMP }\end{array}$ & $\begin{array}{l}\text { MUSS } \\
\text { RIVER }\end{array}$ \\
\hline \multicolumn{13}{|l|}{ AHs } \\
\hline n-decane & 0.024 & 0.063 & 0.032 & 0.023 & 0.024 & . & . & . & 0.025 & 0.029 & 0.042 & 0.126 \\
\hline n-undecane & . & . & 0.022 & . & . & . & . & . & . & . & . & 0.241 \\
\hline n-dodecane & . & . & . & . & . & . & . & . & . & . & . & 0.321 \\
\hline n-tridecane & . & . & . & . & . & . & . & . & . & . & . & 0.308 \\
\hline n-tetradecane & . & . & 0.021 & . & . & . & . & . & . & . & . & 0.262 \\
\hline n-pentadecane & 0.27 & 0.36 & 0.15 & 0.042 & 0.033 & 0.039 & 0.27 & 0.062 & 0.052 & 0.026 & 0.037 & 0.215 \\
\hline n-hexadecane & 0.036 & 0.036 & 0.034 & 0.024 & 0.022 & 0.020 & 0.053 & 0.026 & . & . & 0.020 & 0.119 \\
\hline n-heptadecane & 0.27 & 0.36 & 0.15 & 0.026 & 0.025 & 0.032 & 1.3 & 0.24 & 0.046 & 0.051 & 0.038 & 0.158 \\
\hline pristane & . & . & . & . & . & . & 0.023 & . & . & . & 0.021 & 0.2 \\
\hline n-octadecane & 0.033 & . & . & 0.021 & . & 0.020 & 0.023 & . & 0.025 & . & 0.022 & 0.11 \\
\hline phytane & 0.030 & 0.028 & 0.033 & . & . & . & . & . & . & . & . & 0.115 \\
\hline n-nonadecane & 0.16 & . & . & 0.037 & 0.024 & 0.025 & 0.074 & 0.063 & . & . & 0.074 & 0.113 \\
\hline n-eicosane & 0.027 & 0.028 & 0.053 & . & . & . & 0.020 & . & . & 0.035 & 0.029 & 0.117 \\
\hline n-heneicosane & 0.058 & 0.02 & 0.023 & 0.029 & 0.023 & 0.021 & 0.11 & 0.076 & 0.062 & 0.079 & 0.030 & 0.105 \\
\hline n-docosane & 0.032 & 0.032 & 0.031 & 0.038 & 0.037 & 0.037 & 0.049 & 0.034 & 0.027 & 0.026 & 0.030 & 0.091 \\
\hline n-tricosane & 0.041 & 0.046 & 0.045 & 0.046 & 0.046 & 0.043 & 0.090 & 0.074 & 0.034 & 0.044 & 0.044 & 0.77 \\
\hline n-tetracosane & 0.034 & 0.042 & 0.04 & 0.042 & 0.046 & 0.041 & 0.057 & 0.036 & 0.026 & 0.044 & 0.036 & 0.066 \\
\hline n-pentacosane & 0.048 & 0.052 & 0.053 & 0.066 & 0.045 & 0.051 & 0.074 & 0.052 & 0.11 & 0.071 & 0.100 & 0.083 \\
\hline n-hexacosane & 0.030 & 0.035 & 0.036 & 0.036 & 0.034 & 0.03 & 0.05 & 0.030 & . & 0.041 & 0.031 & 0.053 \\
\hline n-heptacosane & 0.039 & 0.047 & 0.060 & 0.040 & 0.034 & 0.033 & 0.058 & 0.046 & 0.16 & 0.13 & 0.12 & 0.124 \\
\hline n-octacosane & 0.16 & 0.032 & 0.030 & 0.048 & 0.54 & 0.052 & 0.86 & 0.13 & 0.061 & 0.039 & 0.091 & 0.075 \\
\hline n-nonacosane & 0.054 & 0.059 & 0.088 & 0.048 & 0.039 & 0.039 & 0.060 & 0.043 & 0.025 & 0.028 & 0.046 & 0.188 \\
\hline n-triacontane & 0.033 & 0.036 & 0.040 & 0.034 & 0.031 & 0.034 & 0.046 & 0.031 & . & . & . & 0.081 \\
\hline n-hentriacontane & 0.043 & 0.048 & 0.060 & 0.047 & 0.038 & 0.036 & 0.044 & 0.034 & . & . & 0.029 & 0.236 \\
\hline n-dotriacontane & 0.026 & 0.029 & 0.030 & 0.031 & 0.027 & 0.028 & 0.034 & 0.026 & . & . & . & 0.092 \\
\hline n-tritriacontane & 0.027 & 0.03 & 0.039 & 0.034 & 0.027 & 0.03 & 0.036 & 0.023 & . & . & 0.022 & 0.104 \\
\hline n-tetratriacontane & 0.026 & 0.028 & 0.027 & 0.030 & 0.026 & 0.029 & 0.040 & 0.030 & . & . & 0.026 & 0.076 \\
\hline Total AHs & 1.501 & 1.411 & 1.097 & 0.742 & 1.121 & 0.64 & 3.371 & 1.056 & 0.653 & 0.643 & 0.888 & 4.549 \\
\hline
\end{tabular}




\section{Appendix 2. Background and Environmental Relevance}

In order to relate the data from the Davis Pond prediversion monitoring study to historical and regional data, several resources were consulted, including documents generated from the U.S. Geological Survey (USGS) Biomonitoring of Environmental Status and Trends (BEST) program. The BEST program was initiated, in part, as a revision and expansion of the National Contaminant Biomonitoring Program (NCBP). One aspect of the BEST program focused on monitoring contaminants and effects across broad geographic areas. In the BEST program, fish were collected from 46 sites in the Mississippi River basin (1995); 16 sites in the Columbia River basin (1997); 10 sites in the Rio Grande basin (1997); and one reference site in West Virginia. Sites were located at the historical NCBP fish monitoring stations in all three basins; at USGS National Stream Quality Accounting Network (NASQAN) waterquality sampling sites in the Columbia River and Rio Grande basins; and at sites of the National Water-Quality Assessment (NAWQA) program (of the USGS Water Resources Discipline) in the Mississippi Embayment and eastern Iowa River basins study units within the Mississippi River basin.

The primary species targeted at each site in these programs were common carp (Cyprinus carpio) and largemouth bass (Micropterus salmoides); other species, mostly other black basses (Micropterus spp.), percids (Sander spp.), salmonids, suckers (Catostomidae), and catfish (Ictaluridae), were collected as alternates, depending on habitat and location. Individual fish (about 40 per station) were analyzed for several biomarkers in order to assess potential effects of contaminants. For a completion report, full biomarker descriptions, and raw data see Schmitt, Zajicek, and others (1999) and Schmitt (2002).

Several other resources were of value for the current study for relating relevant levels of concern and in explaining possible mechanisms of toxicity, including a text devoted to metal poisoning in fish by Sorenson (1991), a book on interpreting contaminant concentrations (Beyer and others, 1996), a book on metals in fishes (Mance, 1987), the latest report on carcinogenic compounds (National Toxicology Program, 2002), National Oceanic and Atmospheric Administration (NOAA) Screening Quick Reference Tables (SQuiRTs) (Buchman, 2003), the USGS Contaminant Hazard Reviews (Eisler, 1999), Meade's (1995) report on contaminants in the Mississippi River, and references from peer-reviewed literature. Values in the Davis Pond prediversion monitoring survey (hereafter the current study) were compared directly with those documented in the first freshwater diversion project in the New Orleans area, the Caernarvon freshwater diversion report (Conzelmann and others, 1996). In that study, levels were reported for numerous individual fish species as well as for fish composites and oyster composites.

Many characteristics of the hydrologic environment influence the toxicity of compounds to aquatic organisms. For instance, hardness and salinity are factors. The hardness of water increases as more calcium and magnesium ions are dissolved in it. Hardness is reported as the equivalent concentration of calcium carbonate in milligrams per liter. Generally, the toxicity of compounds to fish decreases as the water hardness increases (Mance, 1987). The Mississippi River water in the New Orleans region approximates $10 \mathrm{mg} / \mathrm{L}$; the range of dissolved magnesium from 1905 to 1995 was 8.1$12 \mathrm{mg} / \mathrm{L}$ (Garrison, 1998). The $\mathrm{pH}$ of the Mississippi River changes seasonally; the minimum in 2001 was reported as $\mathrm{pH}$ 7.0 in late January, and the maximum was $\mathrm{pH} 8.1$ in August (Garrison, 1998). The acid and alkaline death points in warmwater fish pond culture are $\mathrm{pH} 4$ and $\mathrm{pH} 11$, respectively, and reproduction diminishes at values below pH 6.5 (Boyd, 1979). Also, reducing salinity generally increases toxicity (Mance, 1987). The conductivity of water is a measure of its ability to convey an electrical current; distilled water has a conductivity of about 1 microsiemens/cm, and natural waters have conductivities of 20-1,500 microsiemens/cm (Boyd, 1979). Further, loads or concentrations of compounds in river water are influenced by river flow. Therefore, for a more accurate comparison of both biomarkers and concentrations in tissues, obtaining samples during one season of the year within a 3-month period would be preferable.

Excessive levels of even essential metals can be detrimental to organisms. Essential metals include cobalt, iron, copper, manganese, molybdenum, vanadium, strontium, and zinc. The nonessential heavy metals of particular concern are cadmium, chromium, mercury, lead, arsenic, and antimony. Heavy metals exist in waters in several phases such as particulate, colloidal, and dissolved. As stated previously, the solubility of trace metals is determined by the water $\mathrm{pH}$, the type and concentration of ligands onto which the trace metal can adsorb, and the redox environment of the system. Sediment composed of fine sand and silt will generally have higher levels of adsorbed metal than will sediment based on other materials. Metals also have a high affinity for humic acids, organoclays, and oxides coated with organic matter. Metals may be desorbed from the sediment if the water increases in salinity (as seen in estuaries), decreases in redox potential (as seen in oxygen-deficient conditions), or decreases in $\mathrm{pH}$.

The noted organic and inorganic compounds that may affect fish health and that were assessed in the current study are discussed individually in the following sections. 


\section{Organochlorines}

The U.S. Environmental Protection Agency

(EPA) lists aldrin, dieldrin, chlordane, $p, p$ '-

dichlorodiphenyltrichloroethane (DDT), mirex, and toxaphene as "level 1" priority persistent, bioaccumulative, and toxic pollutants identified for action through the National Action Plan (U.S. Environmental Protection Agency, 2000). Highly chlorinated, persistent organic pesticides were once widely used in large quantities in the United States. Because evidence supports adverse environmental and human health effects, their use was canceled in the United States in the 1970s and 1980s (U.S. Environmental Protection Agency, 2000).

The most persistent metabolite of the pesticide DDT is dichlorodiphenyldichloroethylene (DDE) (Schmitt, 1990), which along with DDT is reasonably expected to be a human carcinogen. DDT is the common name for the technical product consisting of $65-80$ percent $p, p$ '-DDT. Other components include $o, p$ '-DDT (20 percent), $p, p$ '-TDE (DDD) [1,1-dichloro-2,2-bis(4-chlorophenyl)ethane] (up to 4 percent), and $o, o^{\prime}$-DDT (trace amounts). These compounds are soluble in fats and organic solvents. Environmental residues of DDT and its degradation products persist in many areas from historical use, especially in cotton-growing areas. From 1946 to 1972 , DDT was one of the most widely used insecticides in the world, but in 1972 it was banned.

Toxaphene is reasonably anticipated to be a carcinogen in humans (National Toxicology Program, 2002). Primarily used as an insecticide for cotton and other crops, to control ectoparasites on livestock, and to kill undesirable fish species in lakes and streams, its use has been banned since 1990 (Eisler, 1999). Toxaphene use increased as DDT was phased out, and it became the most heavily used pesticide in the United States in the early to mid-1970s. Mirex was used in the United States from 1958 to 1978 primarily as a fire retardant additive, and approximately 25 percent was used as an insecticide to control fire ants in the Southern United States; it remains persistent in the environment (Eisler, 1999). Banned from use since the mid-1960s, hexachlorobenzene (HCB) was used as a fungicide and is considered an animal carcinogen. Normal development of the male rat reproductive tract has been impeded by HCB, which interferes with androgen action (Ralph and others, 2003) and induces other health problems. This impedence also occurs with organochlorines (OCs), which have similar mechanisms of action.

Several mixtures of polychlorinated biphenyls (PCBs), including Aroclor 1260 and 1254 and Kanochlor 500, are reasonably anticipated to be human carcinogens (National Toxicology Program, 2002). There are approximately 209 possible PCB isomers. Since the early 1970s, all uses of PCBs in the United States have been confined to closed systems such as electrical capacitors, transformers, and gas-transmission turbines. Before 1972, there were many uses, including plasticizers and pesticide extruders, but a ban was implemented in 1979 (Hoffman and others, 1996). Currently, PCB use is granted by petition for use in immersion oil in low fluorescence microscopy and in research and development. PCBs have been found in runoff, sediments, soil, and underground oil-water layers, and they are environmentally persistent, resisting breakdown. They are readily absorbed from water into the fats of plankton and so enter the aquatic food chain through fish and then piscivorous birds, where eagles and other raptors are at the top of the aquatic food chain (Hoffman and others, 1996). Therefore, PCBs and polychlorinated dibenzodioxins accumulate at progressively higher concentrations, or biomagnify, as they become deposited in the fat of the body. In a food web, biomagnification is defined as a diet-dependent increase of contaminant concentrations, above the concentrations expected from equilibrium partitioning with the surrounding water, where biomagnification of lipophilic OCs has been shown in aquatic food chains (Olsson and others, 2000). In humans, three PCB congeners have been shown to be inversely correlated with sperm motility (Bush and others, 1986).

\section{Polycyclic Aromatic Hydrocarbons}

Of the total number of polycyclic aromatic hydrocarbons (PAHs), 15 are carcinogens (National Toxicology Program, 2002; Rice and Arkoosh, 2002). The PAHs have more than one benzene ring in their structure, are ubiquitous in nature, and originate mainly from anthropogenic sources such as discharges from ships, road runoff, petroleum spills, and industrial processes. PAHs form as a result of incomplete combustion of organic matter (Hase and Hites, 1978); many have been identified in the aquatic environment (Kennedy and Law, 1990). Generally, higher levels of PAHs are found in sediments (about 1,000 times more) than in the water column; surface waters have the highest concentrations in the water column (Beyer and others, 1996). Because of the strong binding of hydrophobic organic compounds such as PAHs and PCBs, sediments serve as a long-term source of these contaminants to water bodies and biota (Ghosh and others, 2003). Sixteen PAHs have been recommended as priority pollutants by the EPA and other agencies. In general, PAHs do not biomagnify to their full potential, despite their high lipid solubility, because most PAHs are metabolized (Eisler, 1999). In ecotoxicological studies, after oil spill contamination, xenobiotic metabolizing enzymes such as cytochrome P450 are induced, and PAHs, coplanar PCBs, polychlorinated dibenzofurans, and dibenzodioxins act as inducers of cytochrome P4501A, one of the best-studied biomarkers (Bucheli and Fent, 1995). Studies have shown that levels of liver microsomal cytochrome P450 correlate with contamination by PAHs (Elskus and Stegeman, 1989; Aas and others, 2000). 


\section{Aluminum}

Aluminum is a naturally occurring metal and is generally considered nontoxic (Meade, 1995). The maximum contaminant level of aluminum in ground water is $0.05-0.20$ parts per million (ppm); for surface freshwater, the acute concentration of concern is $0.750 \mathrm{ppm}$; and the chronic concentration level of concern is $0.087 \mathrm{ppm}$ (Buchman, 2003). High levels of ingested aluminum can affect mechanical properties of bones, and changes in mechanical properties of bone may influence avian flight (Hui and Ellers, 1999).

\section{Arsenic}

Arsenic occurs naturally in Earth's crust, often as the sulfide of complex minerals with copper, lead, iron, and other metals. Arsenic is released into the environment from industrial sources, from electric generating stations or power plants, from the use of chemicals to decrease aquatic weeds, and from the use of arsenic-based pesticides and cotton defoliants (Sorenson, 1991; Schmitt, 2002). Arsenic is found in wood preservatives in pressure treatments. Arsenic has not been produced in the United States since 1985. Historically, the EPA limited arsenic in drinking water to a maximum level of $0.05 \mu \mathrm{g} / \mathrm{L}$, and effective as of 2006, the level was lowered to $0.010 \mu \mathrm{g} / \mathrm{L}$. Agricultural applications provide the largest anthropogenic source of arsenic in the environment (Eisler, 1999).

Inorganic arsenicals are more toxic than organic arsenicals, and trivalent forms are more toxic than pentavalent forms (Mance, 1987; Eisler, 1999). Inorganic arsenic compounds are known to be human carcinogens. An association between environmental exposure to arsenic through drinking water and skin cancer has been confirmed. Epidemiological studies showed that drinking water containing $0.35-1.14 \mu \mathrm{g} / \mathrm{L}$ arsenic caused elevated risks for cancers of the bladder and other organs. Liver hepatocytes display effects of arsenic toxicity (Sorenson, 1991).

Arsenic is accumulated from water by a variety of organisms; however, there is no evidence of magnification along the aquatic food chain (Eisler, 1999). Planktivorous fishes tend to accumulate arsenic to a greater degree than do other fishes (Sorenson, 1991). Arsenic accumulation is not correlated with fish total length, dry weight, wet weight, or condition factors (Sorenson, 1991), as is also the case with cadmium and zinc. Adverse effects of arsenicals on aquatic organisms have been reported at concentrations of $1.3-5 \mathrm{mg} /$ $\mathrm{kg} \mathrm{ww}$ in tissue in aquatic animals and in birds at various levels in different species (Eisler, 1999).

\section{Barium}

Barium is a naturally occurring element and is considered as having low toxicity (Meade, 1995). The EPA maximum contaminant level for barium in drinking water is $2 \mathrm{ppm}$ $(\mathrm{mg} / \mathrm{L})$. Common sources of barium in water are discharges of drilling wastes, from metal refineries, and from eroded natural deposits. Barium sulfate is used as a weighting agent for drilling mud, but it is not considered toxic (Manheim and Hayes, 2002). Barium concentrations greater than those expected in naturally occurring sediments have been observed in Lakes Pontchartrain and Maurepas (Manheim and Hayes, 2002). Barium may be a tracer of certain waste streams, and values near New Orleans have reached 4,000 $\mu \mathrm{g} / \mathrm{g}$ in sediment cores from dredged pits.

\section{Boron}

Boron is a naturally occurring element that has moderate to high toxicity (Meade, 1995). Human activities such as mining, coal burning, use of agricultural fertilizers and chemicals, and use of borax laundry detergents have resulted in loadings to air and water. Natural levels are more elevated at higher salinities. Agricultural drainwaters contaminated with boron are considered potentially hazardous to waterfowl and other wildlife populations throughout areas of the Western United States (Smith and Anders, 1989). Boron compounds can accumulate in animal tissues and in aquatic ecosystems because of the relatively high water solubility of boron compounds (see Eisler, 1999). Little is known about the effect of boron ingestion on bird reproduction, although both boric acid and borax produced mortality and teratogenic development when injected into eggs, but no evidence of mutagenicity or carcinogenicity has been indicated (Eisler, 1999). Excessive consumption can adversely affect growth, survival, or reproduction in sensitive mammals. Recommended criteria for the protection of sensitive species include less than $30 \mathrm{mg} / \mathrm{kg}$ in waterfowl diets and less than 1.0 $\mathrm{mg} / \mathrm{L}$ for aquatic life. The effects of boron are highly species specific.

Representative species of aquatic plants, invertebrates, fishes, and amphibians can usually tolerate up to $10 \mathrm{mg} / \mathrm{L}$ of boron for extended periods without adverse effects, although it has been suggested that concentrations greater than $0.1 \mathrm{mg} / \mathrm{L}$ may ultimately affect reproduction in rainbow trout (Oncorhynchus mykiss) and that greater than $0.2 \mathrm{mg} / \mathrm{L}$ may impair survival of other fish species (Eisler, 1999). In waterfowl, diets that contain 30-100 mg/kg ww adversely affect growth rate. Elevated tissue residues were recorded in ducks fed diets containing between 100 and $300 \mathrm{mg} / \mathrm{kg}$, and reduced survival occurred at dietary levels of $1,000 \mathrm{mg} /$ $\mathrm{kg}$. Boron is a potent avian teratogen when injected directly into embryos during the first 96 hours of development. No observed adverse effect was noted for waterfowl when their diet contained less than $13 \mathrm{mg} / \mathrm{kg}$ ww boron, but adverse effects were noted at levels of $30-100 \mathrm{mg} / \mathrm{kg}$ ww. 


\section{Cadmium}

Cadmium is a rare element not found in its pure state in nature, where it typically occurs as a sulfide form in zinc deposits. Cadmium has been used in paint pigments, in dental amalgams, and as a tin substitute, and since World War II, it has been used in batteries, pigments, stabilizers for plastics, coatings and electroplating, and alloys. Dredging, lowered $\mathrm{pH}$, and altered redox potential can increase the bioavailability of cadmium (Eisler, 1999). Use has declined because of concerns about its toxicity (Plachy, 2001). Under the Safe Drinking Water Act of 1974 (as amended, 42 U.S.C., $300 \mathrm{j}-9$ ), the maximum contaminant level for cadmium is 0.005 $\mu \mathrm{g} / \mathrm{L}$. The EPA maximum contaminant level for cadmium in drinking water is $5 \mu \mathrm{g} / \mathrm{L}$ (parts per billion [ppb], or 0.005 $\mathrm{ppm}$ ), and for water supporting aquatic life, it is $12 \mu \mathrm{g} / \mathrm{L}$ (ppb, or 0.012 ppm) (Meade, 1995). Cadmium and cadmium compounds are known to be human carcinogens (National Toxicology Program, 2002). Studies in animals and in isolated cells or tissues indicate that ionic cadmium or compounds that release ionic cadmium cause genetic damage and are carcinogens. Marine organisms are generally more resistant than freshwater biota, and morbidity of animals has been shown to increase with exposure time, a decrease in water hardness, and a decrease in organism age (Eisler, 1999).

Species differ in their responses to cadmium challenge (Sorenson, 1991). Some symptoms of sublethal cadmium levels in animals include growth inhibition, anemia, and testicular damage (Sorenson, 1991; Eisler, 1999). Cadmium tends to accumulate in viscera of vertebrates, especially the liver and kidneys, and cadmium can bioaccumulate in some species (Sorenson, 1991). Birds have been shown to be relatively resistant to lethal effects of elevated cadmium, which is likely due to metallothioneins (proteins that bind heavy metals). Cadmium can interfere with the ability of metallothionein to regulate zinc and copper (Furness, 1996). In birds, intestinal absorption of iron is reduced with an increased dietary intake of cadmium, and elevated concentrations affect iron, zinc, and copper concentrations in tissues (see Furness, 1996), which in turn interferes with enzyme activity.

Cadmium is present in many materials and is released to the environment from a variety of sources; geometric means range from less than $0.01 \mu \mathrm{g} / \mathrm{g}$ to $0.04 \mu \mathrm{g} / \mathrm{g}$ ww (Schmitt, 2002), with $0.17 \mu \mathrm{g} / \mathrm{g} \mathrm{dw}$ (about $0.05 \mu \mathrm{g} / \mathrm{g}$ ww) considered relatively high in fish (Schmitt and Brumbaugh, 1990).

\section{Chromium}

Chromium is widely distributed in air, water, soil, and food. Hexavalent chromium has the greatest biological activity among chromium chemical species, with the toxic effect of chromium ${ }^{+6}$ being related to its strong oxidizing action. The primary uses of chromium are in metallurgy, refractory, and chemical industries, and elevated levels are seen near industrial operations and municipal waste-treatment facilities (Eisler, 1999). It is used in pigments, alloys, bricks, and wood preservatives, and chromium pigments often include strontium, zinc, and lead.

Chromium is essential for normal metabolism in humans and some animals and has been counteractive in the deleterious effects of other metals (Eisler, 1999). No biomagnification has been demonstrated with chromium. Most investigators agree that chromium in biological materials is usually in the trivalent state. Chromium uptake in trout (Salmonidae) increased when $10 \mathrm{ppb}$ of ionic cadmium was present in solution, demonstrating that uptake patterns are not predictable for single components in complex mixtures (Eisler, 1999). In mollusks, concentrations of chromium are reported to decrease with increasing body weight and increasing salinity, suggesting a sort of homeostatic regulation of chromium. Survival was depressed in young American black ducks (Anas rubripes) fed 10 or 50 ppm dietary chromium ${ }^{+3}$ for 10 weeks, suggesting that they may be adversely affected if they remain in contaminated areas for extended periods (Eisler, 1999).

Chromium toxicity to aquatic biota is significantly influenced by abiotic variables such as hardness, temperature, $\mathrm{pH}$, and salinity of water and by biological factors such as species, life stage, and potential differences in sensitivities of local populations. Tissue levels in excess of $4.0 \mu \mathrm{g} / \mathrm{g} \mathrm{dw}$ should be viewed as presumptive evidence of chromium contamination, although the significance of tissue chromium residues is unclear (see Eisler, 1999). Proposed chromium criteria for the protection of animals are tissue concentrations of less than 0.2 ppm ww (about $0.69 \mathrm{dw}$ ). Chromium has moderate to high toxicity and is reasonably expected to be a human carcinogen (Eisler, 1999; National Toxicology Program, 2002).

Chromium, manganese, and lead can be passed to eggs by hens (Gochfeld, 1997), and exposure of embryos to inflated levels is deleterious (Hui, 2002). Rock dove (Columba livia) populations were found to be unaffected by atmospheric levels of these compounds (Hui, 2002).

\section{Copper}

Copper is released from a variety of sources, including mining and industrial processes, and has moderate to high toxicity in the aquatic environment (Meade, 1995). Copper is an essential element found in a number of proteins and enzymes; therefore, complicated mechanisms are involved in regulating internal levels (Sorenson, 1991). Prior exposure to copper enables fish to tolerate higher subsequent exposures (Sorenson, 1991). Toxicity results when external levels exceed a value. Hardness, alkalinity, and $\mathrm{pH}$ of water appear to be important modulating factors for toxicity of copper, and natural waters contain organic complexing agents that can reduce free copper. Copper accumulates preferentially in gills 
and liver (Schmitt, 2002), but deposition in species is variable (Sorenson, 1991). Adverse effects on organism health and physiology in brown trout (Salmo trutta) (Farag and others, 1995) were seen at levels of 5.49-7.56 $\mu \mathrm{g} / \mathrm{g}$ ww. Reduced filtration by zebra mussels (Dreissena spp.) was seen at 50 ppm copper in water; when water had levels at 0.8-1.4 ppm, levels of 12.6-17.7 ppm dw were found in tissue (see Eisler, 1999). The EPA maximum contaminant level for copper in drinking water is $1.3 \mathrm{ppm}(\mathrm{mg} / \mathrm{L})$, and for supporting aquatic life it is 20 ppm (Meade, 1995). Very few data are available on copper toxicity in avian wildlife (Eisler, 1999). Levels in field-collected bald eagle eggs were reported to be up to 1.2 $\mathrm{mg} / \mathrm{kg} \mathrm{ww}$ (Eisler, 1999).

\section{Iron}

Iron is considered a nontoxic metal in the hydrologic environment (Meade, 1995) and is classified as a nonpriority pollutant by the EPA (U.S. Environmental Protection Agency, 2002). The elements aluminum, iron, and manganese are major constituents of sediments (Meade, 1995), and their concentrations in fish may reflect the accumulation of particulate material in the fish (Brumbaugh and Kane, 1985). Therefore, these higher levels in mullet in the current study may reflect their feeding behavior.

\section{Lead}

The EPA regulates lead and certain lead compounds and has established a maximum concentration for lead of 0.05 $\mu \mathrm{g} / \mathrm{L}$ in wastes. The maximum concentration for lead in drinking water is $0.0 \mu \mathrm{g} / \mathrm{L}$. Under the Safe Drinking Water Act, the EPA has set an action level of $0.015 \mu \mathrm{g} / \mathrm{L}$. Much of the environmental lead remains from past emissions (Schmitt, 2002). Lead is readily accumulated in fish from food and water but does not biomagnify (Farag and others, 1998). The 85th percentile from the NCPB for lead (Schmitt and Brumbaugh, 1990) was $0.22 \mu \mathrm{g} / \mathrm{g}$ ww $(0.76 \mu \mathrm{g} / \mathrm{g} \mathrm{dw})$. High levels in fish have been shown to be deleterious to heme synthesis, especially when in combination with zinc (Schmitt and others, 1984; Schmitt, 2002). Generally, organolead compounds have been shown to be more toxic than inorganic lead compounds, and younger organisms are more susceptible (see Eisler, 1999). Lead modifies the function and structure of kidney, bone, the central nervous system, and the hematopoietic system and produces adverse biochemical, histopathological, neuropsychological, fetotoxic, teratogenic, and reproductive effects. Lead concentrations are usually highest in ecosystems near lead mining, smelting, and refining activities; lead storage battery recycling plants; areas of high vehicular traffic; urban and industrialized areas; sewage and spoil disposal areas; dredging sites; and areas of heavy hunting pressure (see Eisler, 1999).

Lead-poisoned waterfowl tend to seek seclusion and often die in areas of heavy cover; these carcasses are rapidly removed by predators and scavengers and may result in secondary lead poisoning, especially among raptors such as the bald eagle (Haliaeetus leucocephalus) (see Eisler, 1999). Of 293 bald eagles found dead nationwide between 1978 and 1981, 17 (5.8 percent) probably died of lead poisoning after ingesting hunter-killed or hunter-crippled waterfowl containing lead pellets (see Eisler, 1999). Endangered condors (Gymnogyps californianus) have been impacted by lead in ammunition: captive birds' levels were found to be 10 times lower than wild condors' blood-lead concentrations (Thacker, 2006).

In water, lead is most soluble and bioavailable under conditions of low $\mathrm{pH}$, low organic content, low concentrations of suspended sediments, and low concentrations of the salts of calcium, iron, manganese, zinc, and cadmium. Accordingly, solubility of lead is low in water, except in areas of local pointsource discharges (see Eisler, 1999). Lead and its compounds tend to concentrate in the water surface microlayer (the upper $0.3 \mathrm{~mm}$ ), especially when surface organic materials are present in thin films (see Eisler, 1999).

\section{Magnesium}

Magnesium is considered a nontoxic metal in the hydrologic environment (Meade, 1995). Magnesium has been found to reduce toxicity of zinc. This has been used to explain the effect of increased water hardness in reducing zincinduced toxicity (Sorenson, 1991).

\section{Mercury}

Mercury in water can come from erosion of natural deposits, discharge from refineries and factories, emissions from coal-fired plants, and runoff from landfills and croplands. Most of the mercury in whole fish occurs as the highly toxic methylmercury (Schmitt, 2002), whereby methylation is primarily a microbial process. Some environmental conditions often associated with high mercury levels include newly flooded reservoirs, waters with low acid-neutralizing capacity, high humic content, shallow lakes with high littoral/pelagic ratios, gold mining, industrial discharges, agricultural use of alkylmercury fungicides, and disturbed wetlands. A direct relationship exists between deposition of inorganic mercury and the production of methylmercury (Orihel and others, 2007). Mercury accumulates with size and age in predatory fishes to a greater extent than do most other contaminants (Wiener and Spry, 1996). The diet is the primary route of methylmercury uptake by fish in natural waters, and accumulation seems to be most rapid in summer months (Wiener and Spry, 1996). Mercury has been shown to have various effects on reproduction in several species of fish, including toxicity to embryos, teratogenicity, and reduction in hatchability. Mercury can induce necrotic changes in any organ examined (Sorenson, 1991).

Monitoring programs for mercury typically employ fillet 
or whole body samples. Muscle is the primary tissue for which data have been obtained on methylmercury-intoxicated fish in laboratory and field studies. The concentration ranges for lab studies are similar (Wiener and Spry, 1996); the threshold whole-fish concentration for adverse effects of methylmercury on fish is in the range of $0.7-5.3 \mu \mathrm{g} / \mathrm{g}$ ww, varying with taxon. The 85th percentile from the NCBP for mercury (Schmitt and Brumbaugh, 1990) was $0.17 \mu \mathrm{g} / \mathrm{g}$ ww $(0.59 \mu \mathrm{g} / \mathrm{g} \mathrm{dw})$.

The regulatory and scientific focus on mercury in aquatic ecosystems has been motivated largely by the health risks of consuming contaminated fish because exposure to methylmercury is almost wholly due to consumption of fish. The EPA maximum concentration of mercury in drinking water is $0.002 \mathrm{ppm}$, and for supporting aquatic life it is 0.05 ppm (Meade, 1995). (The EPA and U.S. Food and Drug Administration provide consumption advisories [http://www.fda.gov/bbs/topics/news/2004/NEW01038. $h t m l]$ ). The EPA aquatic life criterion for mercury (U.S. Environmental Protection Agency, 1980) was based on the hazard to humans rather than hazards to fish; the criterion established that the concentration in water can result in $1 \mathrm{mg} /$ $\mathrm{kg}(\mathrm{ppm}) \mathrm{ww}$ in fish. Louisiana has adopted a more restrictive human health advisory standard of $0.5 \mathrm{mg} / \mathrm{kg}$, consistent with the recommendations by the National Research Council National Academy of Sciences Panel on Mercury (1978).

Methylmercury is a heavy metal organotoxin formed primarly by sulfate-reducing bacteria in anoxic sediments, and it is primarily the form that can be geologically concentrated and biomagnified through food chains (Eisler, 1999). Bioaccumulation and toxicity of mercury are both ameliorated by selenium, but the mechanisms and extent of these effects are not well characterized (Ralston and others, 2006). Methylmercury has been found to decrease reproduction of adult fathead minnow (Pimephales promelas) at dietary concentrations encountered by predatory fishes in aquatic systems with methylmercury-contaminated food webs (Hammerschmidt and others, 2002) and to induce brain injury and alter behavior (Berntssen and others, 2003). The level at which mercury is lethal to birds varies with species, sex, age, and physiological condition. The intake of mercury in wild birds almost exclusively occurs via contaminated food. Reduced hatchability, fertility, and embryo vitality have been seen in various bird species influenced by mercury in their diet (see Fimreite, 1979).

\section{Nickel}

Nickel compounds are reasonably anticipated to be human carcinogens (National Toxicology Program, 2002). Nickel is regulated by the EPA's clean water effluent guideline for industrial point sources. Nickel is ubiquitous in the biosphere and is essential for growth of some species of plants and animals (Eisler, 1999). Nickel is found in scrap metal recycling, in electroplating, as a chemical catalyst, in alkaline batteries, in coins and machinery parts, and in fossil fuels (Sevin, 1980). Nickel was at one time refined in Louisiana, but the refinery in Braithwaite in Plaquemines Parish stopped producing nickel compounds in the mid-1980s.

In aquatic systems, nickel occurs as soluble salts adsorbed onto or associated with clay particles or organic matter (see Eisler, 1999). Mixtures of metals (arsenic, cadmium, copper, chromium, mercury, lead, and zinc) containing nickel salts are more toxic to water fleas (Daphniidae) and fishes than are individual nickel components (Enserink and others, 1991). Nickel-mediated carcinogenic damage has been shown: breakage of deoxyribonucleic acid (DNA), mutations, chromosomal damage, cell transformation, and disrupted DNA repair (National Toxicology Program, 2002). Nickel can bind ionically to cellular components, and it has been shown to inhibit cellular antioxidant defenses by the production of reactive oxygen species (see Eisler, 1999). Albumin is the main transport protein in blood. Concentrations in whole blood, serum, and urine are good indices of nickel exposure (see Eisler, 1999). Nickel is soluble in lipids and penetrates cell membranes. Nickel is a reproductive toxicant in animals; degenerative changes have been shown in testes, epididymis, and spermatozoa of rats (see Eisler, 1999), and it can affect the immune, cardiac, and excretory systems.

Nickel concentrations in fish tissues from nickelcontaminated environments were reported to be $52 \mu \mathrm{g} / \mathrm{g}$ ww (Eisler, 1999). Nickel concentrations in avian tissues in excess of $10 \mathrm{mg} / \mathrm{kg} \mathrm{dw}(\sim 2.9 \mathrm{mg} / \mathrm{kg} \mathrm{ww})$ for kidney or $3 \mathrm{mg} / \mathrm{kg} \mathrm{dw}$ (about $0.87 \mathrm{mg} / \mathrm{kg} \mathrm{ww}$ ) for liver are sometimes associated with adverse effects. For most avian species examined, when internal organs exhibited less than $3 \mathrm{mg} / \mathrm{kg} \mathrm{dw}$ (about 0.87 $\mathrm{mg} / \mathrm{kg} \mathrm{ww}$ ), pathology was normal, but nickel-contaminated environments have elevated internal organs with nickel levels as high as $30 \mathrm{mg} / \mathrm{kg} \mathrm{dw}$ (about $8.7 \mathrm{mg} / \mathrm{kg} \mathrm{ww}$ ).

\section{Selenium}

Almost all selenium is a byproduct of copper refining (National Toxicology Program, 2002). It is widely distributed in the environment, occurring in ground water, surface water, rocks, soils, and food, and it is an essential element associated with antioxidant functions (Brigelius-Flohe, 1999). Most environmental selenium is present as selenite $\left(\mathrm{Se}^{+6}\right)$ at about 0.2-0.4 ppm. In the United States, selenium is normally present at levels of about $0.47 \mathrm{ppm}$ ww fish, but whole body levels of about $1 \mathrm{ppm}$ are not uncommon (Sorenson, 1991). Dry weight levels of selenium from contaminated sites ranged from 4.28 to $197 \mathrm{ppm}$ (1.24 to $57.13 \mathrm{ppm} \mathrm{ww}$ ) (Sorenson, 1991). Coal and petroleum combustion are the main sources of selenium pollution. Scrubber sludge is a powerplant waste in which selenium may be a contaminant. Discharges from coal ash waste into watersheds have resulted in direct mortality of individual fishes and in reproductive failure (see Sorenson, 1991). High concentrations of selenium are deposited on the surface of the smallest particulates released 
from powerplants, where the 1-um-diameter particles can lodge in alveoli in air-breathing animals and solubilize toxic elements. Selenium is methylated and demethylated in the environment and cycled through a number of components of the food web. Its interactions with other environmental contaminants — such as mercury, cadmium, and arsenic — can complicate interpretations of biological impacts (Heinz, 1996).

Selenium is one of the most toxic elements to fish. The EPA maximum contaminant level in drinking water is 0.05 ppm (U.S. Environmental Protection Agency, 2002), and the 85th percentile from the NCBP (Schmitt and Brumbaugh, 1990) was 0.73 ppm ww in fish tissue. Selenium-induced toxicity varies with species, temperature, the presence of parasites, specimen age, source, exposure concentration and time, dietary source, and chemical form. Length of dietary exposure is correlated with increased negative effects. When selenium was at a level of $3.2 \mathrm{ppm} \mathrm{dw}$ in diet, growth of mosquitofish (Gambusia spp.) was decreased in 90 days (Sorenson, 1991).

Selenium has been implicated in reproductive failure (Williams and others, 1989) and in elimination of fish communities (Beyer and others, 1996). Selenium exacerbates the reproductive toxicity effects induced by mercury. Mortality of zebrafish (Danio rerio) larvae increased sharply at the level of 3 ppm selenium. Ascites (abdominal fluid) and convex spinal flexure are symptomatic. The liver is the major concentrating organ. Anemia is a result of excess or low levels, at which there are low erythrocyte numbers and irregularly shaped cells. The toxic effects threshold for overall fish health and reproductive vigor is $4 \mu \mathrm{g} / \mathrm{g} \mathrm{dw}$ whole body selenium (Lemly, 1996). The margin between normal and unhealthful concentrations of selenium is small, and the element tends to bioaccumulate (Beyer and others, 1996).

\section{Zinc}

Zinc is released into the environment from a number of sources primarily associated with human activities (about 96 percent) (Eisler, 1999) and is considered to range from moderate to highly toxic in hydrologic environments (Meade, 1995). Major sources of anthropogenic zinc are discharges from industrial sewage, combustion of fossil fuels, road surface runoff, and erosion of agricultural soils (Eisler, 1999). Zinc is ubiquitous in tissues of plants and animals and is essential for normal growth, reproduction, and wound healing (Eisler, 1999). After ingestion, it is absorbed across membranes in several organs. It forms stable complexes with sulfur, phosphorus, and carbon, and it is an essential element that works as a cofactor for enzymes, many of which interact with DNA and ribonucleic acid (RNA) (Eisler, 1999). Metallothioneins play a role in zinc homeostatis, and in turn, zinc is a potent inducer of metallothioneins (Eisler, 1999). Concentrations of zinc are normally less than $700 \mu \mathrm{g} / \mathrm{kg} \mathrm{dw}$ in fish and less than $210 \mu \mathrm{g} / \mathrm{kg} \mathrm{dw}$ in birds. Zinc uptake in fish is used as an indicator of contamination in waters, and low oxygen levels decrease the tolerance of fish to zinc; conversely, hardwater increases the tolerance of fish to zinc. Effects are lethal or sublethal for most fish species in the range 50-235 $\mu \mathrm{g} \mathrm{Zn/L} \mathrm{(parts} \mathrm{per} \mathrm{billion),} \mathrm{and} \mathrm{reproductive}$ impairment is a sensitive indicator (Eisler, 1999). Males have an increased susceptibility to zinc poisoning in a number of fish species, and zinc can inhibit spawning (Sorenson, 1991). Tissue residues may not be a reliable indication of zinc contamination (Eisler, 1999). Impacts of zinc deficiency in animals include growth retardation, testicular atrophy, skin changes, and poor appetite. Symptoms of exposure to high zinc levels are difficult ventilation and gill damage. Peachfaced lovebirds (Agapornis roseicollis) died within 5 weeks of placement in a newly erected wire cage; dead birds had elevated liver zinc concentrations of $75-156 \mathrm{mg} / \mathrm{kg} \mathrm{dw}$ versus normal values of 21-33 mg/kg dw (Eisler, 1999).

\section{References}

Aas, E., Baussant, T., Balk, L., Liewenborg, B., and Anderson, O.K., 2000, PAH metabolites in bile, cytochrome P4501A and DNA adducts as environmental risk parameters for chronic oil exposure - a laboratory experiment with Atlantic cod: Aquatic Toxicology, v. 51, no. 2, p. 241-258.

Berntssen, M.H.G., Aatland, A., and Handy, R.D., 2003, Chronic dietary mercury exposure causes oxidative stress, brain lesions, and altered behaviour in Atlantic salmon (Salmo salar) parr: Aquatic Toxicology, v. 65, p. 55-72.

Beyer, W.N., Heinz, G.H., and Redmon-Norwood, A.W., 1996, Environmental contaminants in wildlife: Boca Raton, Fla., CRC Press, Inc.

Boyd, C.E., 1979, Water quality in warmwater fish ponds: Auburn, Ala., Auburn University.

Brigelius-Flohe, R., 1999, Tissue-specific functions of individual glutathione peroxidases: Free Radical Biology and Medicine, v. 27, p. 951-965.

Brumbaugh, W.G., and Kane, D.A., 1985, Variability of aluminum concentrations in organs and whole bodies of smallmouth bass (Micropterus dolomieui): Environmental Science and Technology, v. 19, p. 828-831.

Bucheli, T.D., and Fent, K., 1995, Induction of cytochrome P450 as a biomarker for environmental contamination in aquatic ecosystems: Critical Reviews in Environmental Science and Technology, v. 25, no. 3, p. 201-268.

Buchman, M.F., 2003, NOAA Screening Quick Reference Tables: National Oceanic and Atmospheric Administration Coastal Protection and Restoration Division, p. 99-1, 1 p. 
Bush, B., Bennett, A.H., and Snow, J.T., 1986, Polychlorobiphenyl congeners P,P'-DDE, and sperm function in humans: Archives of Environmental Contamination and Toxicology, v. 15, p. 333-341.

Conzelmann, P.J., Schultz, T.W., and Vogl, B.T., 1996, Caernarvon freshwater diversion contaminants monitoring study, 1990-1994: Atlanta, Ga., LFO-EC-96-02, study identifiers 91-4-4249 and 90-4-4249, 71 p.

Eisler, R., 1999, Contaminant hazard reviews 1-35, 19851999: U.S. Geological Survey Biological Science Report USGS/BRD/BSR-1997-0002, online at http://www.pwrc. usgs.gov/infobase/eisler/reviews.cfm

Elskus, A.A., and Stegeman, J.J., 1989, Induced cytochrome P-450 in Fundulus heteroclitus associated with environmental contamination by polychlorinated bipheynyls and polynuclear aromatic hydrocarbons: Marine Environmental Research, v. 27, p. 31-50.

Enserink, E.L., Maas-Diepeveen, J.L., and Van Leeuwen, C.J., 1991, Combined effects of metals — an ecotoxicological evaluation: Water Research, v. 25, p. 679-687.

Farag, A.M., Stansburg, M.A., Hogstrand, C., MacConnell, E., and Bergman, H.L., 1995, The physiological impairment of free ranging brown trout exposed to metals in the Clark Fork River, Montana: Canadian Journal of Fisheries and Aquatic Sciences, v. 52, p. 2038-2050.

Farag, A.M., Woodward, D.F., Goldstein, J.N., Brumbaugh, W., and Meyer, J.S., 1998, Concentrations of metals associated with mining waste in sediments, biofilm, benthic macroinvertebrates, and fish from the Coeur d'Alene River Basin, Idaho: Archives of Environmental Contamination and Toxicology, v. 34, p. 119-127.

Fimreite, N., 1979, Accumulation and effects of mercury on birds, in Nriagu, J.O., ed., The biogeochemistry of mercury in the environment: Elsevier, p. 601-627.

Furness, R.W., 1996, Cadmium in birds, in Environmental contaminants in wildlife-interpreting tissue concentrations: New York, CRC Lewis Publishers, p. 389-404.

Garrison, C.R., 1998, Statistical summary of surface-water quality in Louisiana-Mississippi River mainstem, 1905-95: U.S. Geological Survey Water Resources Technical Report, Louisiana Department of Transportation and Development no. 551,91 p.
Ghosh, U., Zimmerman, J.R., and Luthy, R.G., 2003, PCB and PAH speciation among particle types in contaminated harbor sediments and effects on PAH bioavailability: Environmental Science and Technology, v. 37, p. 2209 2217.

Gochfeld, M., 1997, Spatial patterns in a bioindicator-heavy metal and selenium concentration in eggs of herring gulls (Larus argentatus) in the New York Bight: Archives of Environmental Contamination and Toxicology, v. 33, p. $63-70$.

Hammerschmidt, C.R., Sandheinrich, M.B., Wiener, J.G., and Rada, R.G., 2002, Effects of dietary methylmercury on reproduction of fathead minnows: Environmental Science and Technology, v. 36, p. 877-883.

Hase, A., and Hites, R.A., 1978, On the origin of polycyclic aromatic hydrocarbons in the aqueous environment, in Keith, L.H., ed., Identification and analysis of organic pollutants in water: Ann Arbor, Mich., Ann Arbor Science.

Heinz, G.H., 1996, Selenium in birds, in Beyer, W.N., Heinz, G.H., and Redmon-Norwood, A.W., eds., Environmental contaminants in wildlife-interpreting tissue concentrations: New York, CRC Lewis Publishers, p. 447-458.

Hoffman, D.J., Rice, C.D., and Kubiak, T.J., 1996, PCBs and dioxins in birds, in Beyer, J., Heinz, G.H., and RedmonNorwood, A.W., eds., Environmental contaminants in wildlife-interpreting tissue concentrations: New York, CRC Lewis Publishers, p. 165-207.

Hui, C.A., 2002, Concentrations of chromium, manganese, and lead in air and in avian eggs: Environmental Pollution, v. 120, p. 201-206.

Hui, C.A., and Ellers, O., 1999, Effect of high aluminum consumption on mechanics and composition of furculae of free-ranging coots: Environmental Toxicology and Chemistry, v. 18, p. 970-975.

Kennedy, C.J., and Law, F.C.P., 1990, Toxicokinetics of selected polycyclic aromatic hydrocarbons in rainbow trout following different routes of exposure: Environmental Toxicology and Chemistry, v. 9, p. 133-139.

Lemly, A.D., 1996, Selenium in aquatic organisms, in Beyer, W.N., Heinz, G.H., and Redmon-Norwood, A.W., eds., Environmental contaminants in wildlife-interpreting tissue concentrations: New York, CRC Lewis Publishers, p. 427-445. 
Mance, G., 1987, Pollution threat of heavy metals in aquatic environments: Essex, England, Elsevier, 372 p.

Manheim, F.T., and Hayes, L., 2002, Lake Pontchartrain basin-bottom sediments and related environmental resources: U.S. Geological Survey Professional Paper 1634.

Meade, R.H., 1995, Contaminants in the Mississippi River 1987-1992, USGS: U.S. Geological Survey Circular 1133, $140 \mathrm{p}$.

National Research Council National Academy of Sciences Panel on Mercury, 1978, An assessment of mercury in the environment - a report: Washington, National Academy of Sciences, $185 \mathrm{p}$.

National Toxicology Program, 2002, Report on carcinogens (10th ed.) — carcinogen profiles: Research Triangle Park, N.C., U.S. Department of Health and Human Services, Public Health Service, National Toxicology Program 263 p.

Olsson, A., Valters, K., and Burreau, S., 2000, Concentrations of organochlorine substances in relation to fish size and trophic position - a study on perch (Perca fluviatilis L.): Environmental Science and Technology, v. 34, no. 23, p. 4878-4886.

Orihel, D.M., Paterson, M.J., Blanchfield, P.J., Bodaly, R.A., and Hintelmann, H., 2007, Experimental evidence of a linear relationship between inorganic mercury loading and methylmercury accumulation by aquatic biota: Environmental Science and Technology, v. 41, p. 49524958.

Plachy, J., 2001, Minerals yearbook-cadmium: Washington, D.C., U.S. Geological Survey, last accessed April 25, 2008, at http://minerals.usgs.gov/minerals/pubs/commodity/ cadmium/140498.pdf

Ralph, J.L., Orgebin-Crist, M., Kareyre, J., and Nelson, C.C., 2003, Disruption of androgen regulation in the prostate by the environmental contaminant hexachlorobenzene: Environmental Health Perspectives, v. 111, p. 461-466.

Ralston, C.R., Blackwell, J.L., and Ralston, N.V.C., 2006, Effects of dietary selenium and mercury on house crickets (Acheta domesticus L.)_implications of environmental co-exposures: Environmental Bioindicators, v. 1, p. 98-109.

Rice, C.D., and Arkoosh, M.R., 2002, Immunological indicators of environmental stress and disease susceptibility in fish, in Adams, S.M., ed., Biological indicators of aquatic ecosystem stress, p. 187-220.
Schmitt, C.J., 1990, Persistent organochlorine and elemental contaminants in freshwater fish of the United States- the national contaminant biomonitoring program, in Gray, R.H., ed., Environmental monitoring, restoration and assessment-what have we learned?: Richland, Wash., U.S. Department of Energy, Pacific Northwest Laboratory, p. $5-14$.

Schmitt, C.J., 2002, Biomonitoring of environmental status and trends (BEST) program-environmental contaminants and their effects on fish in the Mississippi River basin: U.S. Geological Survey Biological Science Report USGS/BRD/ BSR-2002-2004, last accessed April 25, 2007, at http:// www.cerc.usgs.gov/pubs/center/pdfDocs/BEST_1995.pdf

Schmitt, C.J., and Brumbaugh, W.G., 1990, National contaminant biomonitoring program-concentrations of arsenic, cadmium, copper, lead, mercury, selenium, and zinc in U.S. freshwater fish, 1976-1984: Archives of Environmental Contamination and Toxicology, v. 19, p. 731-747.

Schmitt, C.J., Dwyer, F.J., and Finger, S.E., 1984, Bioavailability of $\mathrm{Pb}$ and $\mathrm{Zn}$ from mine tailings as indicated by erythrocyte delta-aminolevulinic acid dehydratase (ALA-D) activity in suckers (Pisces: Catostomidae): Canadian Journal of Fisheries and Aquatic Sciences, v. 41, p. 1030-1040.

Schmitt, C.J., Zajicek, J.L., May, T.W., and Cowman, D.F., 1999, Organochlorine residues and elemental contaminants in U.S. freshwater fish, 1976-1986 - national contaminant biomonitoring program: Reviews in Environmental Contamination and Toxicology, v. 162, p. 43-104.

Sevin, I.F., 1980, Nickel, in Waldron, H.A., ed., Metals in the environment: London, Academic Press, p. 263-291.

Smith, G.J., and Anders, V.P., 1989, Toxic effects of boron on mallard reproduction: Environmental Toxicology and Chemistry, v. 8, p. 943-950.

Sorenson, E.M., 1991, Metal poisoning in fish: Boca Raton, Fla., CRC Press Inc., 374 p.

Thacker, P.D., 2006, Condors are full of lead: Environmental Science and Technology, v. 40, p. 5826.

U.S. Environmental Protection Agency, 1980, Ambient water quality criteria document for mercury: Springfield, Va., National Technical Information Service, U.S. Environmental Protection Agency Report 440/5-80-058. 
U.S. Environmental Protection Agency, 2000, The USEPA Persistent, Bioaccumulative, and Toxic Pollutants (PBT) Pesticides Work Group: U.S. Environmental Protection Agency, Draft PBT national action plan for the level 1 pesticides, $107 \mathrm{p}$.

U.S. Environmental Protection Agency, 2002, National primary drinking water standards: U.S. Environmental Protection Agency, 816-F-02-013.

Wiener, J.G., and Spry, D.J., 1996, Toxicological significance of mercury in freshwater fish, in Beyer, W.N., Heinz, G.H., and Redmon-Norwood, A.W., eds., Environmental contaminants in wildlife: Clemson, Lewis Publishers, $\mathrm{p}$. 297-339.

Williams, M.L., Hothem, R.L., and Ohlendorf, H.M., 1989, Recruitment failure in American avocets and black-necked stilts nesting at Kesterson Reservoir, California, 1984-1985: The Condor, v. 91, p. 797-802. 


\section{Appendix 3. Citations for Chemical Names and Abbreviations}

Table 3-1. Citations for chemical names and abbreviations.

[Final list compiled according to the National Institute of Standards and Technology (NIST) Web site (http://webbook.nist.gov/chemistry/); NIST Standard Reference Database No. 69, June 2005 release, last accessed May 9, 2008. CAS, Chemical Abstracts Service. This report contains CAS Registry Numbers ${ }^{\circledR}$, which is a Registered Trademark of the American Chemical Society. CAS recommends the verification of the CASRNs through CAS Client Services $\left.{ }^{\mathrm{SM}}\right]$

\begin{tabular}{|c|c|c|}
\hline Aliphatic hydrocarbons & CAS registry number & Some alternative nan \\
\hline n-decane & $124-18-5$ & \\
\hline n-undecane & $1120-21-4$ & \\
\hline n-dodecane & $112-40-3$ & \\
\hline n-tridecane & $629-50-5$ & \\
\hline n-tetradecane & $629-59-4$ & \\
\hline n-pentadecane & $629-62-9$ & \\
\hline n-hexadecane & $544-76-3$ & \\
\hline n-heptadecane & $629-78-7$ & \\
\hline pristane & $1921-70-6$ & \\
\hline n-octadecane & $593-45-3$ & \\
\hline phytane & $638-36-8$ & \\
\hline n-nonadecane & $629-92-5$ & \\
\hline n-eicosane & $112-95-8$ & n-Icosane \\
\hline n-heneicosane & $629-94-7$ & n-Henicosane \\
\hline n-docosane & $629-97-0$ & \\
\hline n-tricosane & $638-67-5$ & \\
\hline n-tetracosane & $643-31-1$ & \\
\hline n-pentacosane & $629-99-2$ & \\
\hline n-hexacosane & $630-01-3$ & \\
\hline n-heptacosane & $593-49-7$ & \\
\hline n-octacosane & $630-02-4$ & \\
\hline n-nonacosane & $630-03-5$ & \\
\hline n-triacontane & $638-68-6$ & \\
\hline n-hentriacontane & $630-04-6$ & \\
\hline n-dotriacontane & $544-85-4$ & \\
\hline n-tritriacontane & $630-05-7$ & \\
\hline n-tetratriacontane & $14167-59-0$ & \\
\hline
\end{tabular}


Table 3-1. Citations for chemical names and abbreviations.-Continued

[Final list compiled according to the National Institute of Standards and Technology (NIST) Web site (http://webbook.nist.gov/chemistry/); NIST Standard Reference Database No. 69, June 2005 release, last accessed May 9, 2008. CAS, Chemical Abstracts Service. This report contains CAS Registry Numbers ${ }^{\circledR}$, which is a Registered Trademark of the American Chemical Society. CAS recommends the verification of the CASRNs through CAS Client Services ${ }^{\mathrm{SM}}$ ]

\section{Organochlorines}

(HCB) hexachlorobenzene

(alpha-BHC) alpha-benzene hexachloride

(gamma-BHC) gamma-benzene hexachloride

$58-89-9$

(beta-BHC) beta-benzene hexachloride

$319-85-7$

(delta-BHC) delta-benzene hexachloride

319-86-8

oxychlordane

$27304-13-8$

heptachlor epoxide

$1024-57-3$

gamma-chlordane

$5103-74-2$

$39765-80-5$

trans-nonachlor

toxaphene

PCB-Total
8001-35-2

N/A
Some alternative names

Benzene, hexachloro-; Perchlorobenzene; Amatin; Anticarie; Bunt-cure; Bunt-no-more; Hexcachlorbenzen; Hexachlorobenzene

$\alpha$-Lindane; Cyclohexane, 1,2,3,4,5,6-hexachloro-; Cyclohexane, $\alpha$-Hexachlorane; $\alpha$-Hexachlorcyclohexane; $\alpha$-Hexachlorocyclohexane; $\alpha-\mathrm{HCH} ; \alpha-1,2,3,4,5,6-$ Hexachlorocyclohexane; ENT 9,232; Hexachlorcyclohexan; $1-\alpha, 2-\alpha, 3-\beta, 4-\alpha, 5-\beta, 6-\beta$-Hexachlorocyclohexane; $\alpha$-bhc; HCH- $\alpha$

Lindane; Cyclohexane, 1,2,3,4,5,6-hexachloro-, (1 $\alpha, 2 \alpha, 3 \beta, 4 \alpha, 5 \alpha, 6 \beta)$-; Cyclohexane, 1,2,3,4,5,6-hexachloro-, $\gamma$-; $\gamma$-Benzene hexachloride; $\gamma$-BHC; $\gamma$-Hexachloran; $\gamma$-Hexachlorane; $\gamma$-Hexachlorobenzene; $\gamma$-Hexachlorocyclohexane; $\gamma$-HCH; $\gamma$-Lindane; Gammasan; Lindafor; Murfume grain store smoke; New kotol; Scabene lotion; Viton; Cyclohexane, 1,2,3,4,5,6-hexachloro-, $\gamma$-isomer

Cyclohexane, 1,2,3,4,5,6-hexachloro-, $(1 \alpha, 2 \beta, 3 \alpha, 4 \beta, 5 \alpha, 6 \beta)$-; Cyclohexane, 1,2,3,4,5,6-hexachloro-, $\beta$-; $\beta$-Benzene hexachloride; $\beta$-Hexachlorocyclohexane; $\beta$-HCH; $\beta$-Lindane; $\beta$-bhc; $\mathrm{BHC}(\beta)$; HCH- $\beta$

$\delta$-Lindane; Cyclohexane, 1,2,3,4,5,6-hexachloro-, (1 $\alpha, 2 \alpha, 3 \alpha, 4 \beta, 5 \alpha, 6 \beta)-;$ Cyclohexane, 1,2,3,4,5,6-hexachloro-, $\delta$-; $\delta$-(Aeeee)-1,2,3,4,5,6-Hexachlorocyclohexane; $\delta$-Benzene hexachloride; $\delta$-BHC; Bhc $\delta$; 1,2,3,4,5,6-Hexachlorocyclohexane

2,5-Methano-2h-indeno[1,2-b]oxirene, 2,3,4,5,6,6a,7,7octachloro-1a,1b,5,5a,6,6a-hexahydro-, (1a $\alpha, 1 \mathrm{~b} \beta, 2 \alpha, 5 \alpha, 5 \mathrm{a} \beta, 6 \beta, 6 \mathrm{a} \alpha)-;$ 4,7-Methanoindan, 1,2,4,5,6,7,8,8-octachloro-2,3-epoxy-3a,4,7,7a-tetrahydro-, exo,endo-; Octachlor epoxide; Oxychlordan

2,5-Methano-2H-indeno[1,2-b]oxirene, 2,3,4,5,6,7,7-heptachloro1a, 1b,5,5a,6,6a-hexahydro-, (1a $\alpha, 1 \mathrm{~b} \beta, 2 \alpha, 5 \alpha, 5 \mathrm{a} \beta, 6 \beta, 6 \mathrm{a} \alpha)$-; 4,7-Methanoindan, 1,4,5,6,7,8,8-heptachloro-2,3-epoxy3a,4,7,7a-tetrahydro-; $\beta$-Heptachlorepoxide; Epoxyheptachlor; ENT 25,584; HCE; Velsicol 53-CS-17; Heptachlore epoxide

Trans-chlordane with other names: 4,7-Methano-1Hindene, 1,2,4,5,6,7,8,8-octachloro-2,3,3a,4,7,7ahexahydro-, $(1 \alpha, 2 \beta, 3 \mathrm{a} \alpha, 4 \beta, 7 \beta, 7 \mathrm{a} \alpha)-;$ 4,7-Methanoindan, $1 \beta, 2 \alpha, 4 \alpha, 5,6,7 \alpha, 8,8$-octachloro-3a $\beta, 4,7,7 \mathrm{a} \beta$-tetrahydro-; $\beta$-Chlordan; $\beta$-Chlordane; trans-Chlordan; Chlordan, trans-; 4,7-Methanoindan, 3a- $\beta, 4,7,7 \mathrm{a}-\beta$-tetrahydro- $1-\beta, 2-\alpha, 4$ $\alpha, 5,6,7-\alpha, 8,8$-octachloro-; trans- $\gamma$-Chlordane; Chlordane trans; Chlordane $\gamma$ (trans) 
Table 3-1. Citations for chemical names and abbreviations.-Continued

[Final list compiled according to the National Institute of Standards and Technology (NIST) Web site (http://webbook.nist.gov/chemistry/); NIST Standard Reference Database No. 69, June 2005 release, last accessed May 9, 2008. CAS, Chemical Abstracts Service. This report contains CAS Registry Numbers ${ }^{\circledR}$, which is a Registered Trademark of the American Chemical Society. CAS recommends the verification of the CASRNs through CAS Client Services ${ }^{\text {SM }}$ ]

\begin{tabular}{lccc} 
& Organochlorines & CAS registry number \\
\hline$o, p$ '-DDE & $3424-82-6$ & B
\end{tabular}

Benzene, 1-chloro-2-[2,2-dichloro-1-(4-chlorophenyl) ethenyl]-; o,p-DDE; 1,1-Dichloro-2-(o-chlorophenyl)2-(p-chlorophenyl)ethylene; 2-(2-Chlorophenyl)-2-(4chlorophenyl)-1,1-dichloroethylene; 1,1-Dichloro-2(o-chlorophenyl)-2-(p-chlorophenyl)ethene; Ethylene, 1-(o-chlorophenyl)-1-(p-chlorophenyl)-2,2-dichloro-; 1-Chloro2-[2,2-dichloro-1-(4-chlorophenyl)vinyl]benzene; 2,4'-DDE

alpha-chlordane

$5103-71-9$

$p, p^{\prime}-\mathrm{DDE}$

$72-55-9$

Dieldrin

$60-57-1$

$o, p^{\prime}-\mathrm{DDD}$
Cis-chlordane with other names: 4,7-Methano-1Hindene, 1,2,4,5,6,7,8,8-octachloro-2,3,3a,4,7,7ahexahydro-, $(1 \alpha, 2 \alpha, 3 \mathrm{a} \alpha, 4 \beta, 7 \beta, 7 \mathrm{a} \alpha)-;$ 4,7-Methanoindan, $1 \alpha, 2 \alpha, 4 \beta, 5,6,7 \beta, 8,8$-octachloro-3a $\alpha, 4,7,7 \mathrm{a} \alpha$-tetrahydro-; $\alpha$-Chlordan; $\alpha$-Chlordane; cis-Chlordan; Chlordan, cis-; Chlordane cis

Benzene, 1,1'-(dichloroethenylidene)bis[4-chloro-; Ethylene, 1,1-dichloro-2,2-bis(p-chlorophenyl)-; p,p'-(Dichlorodiphenyl) dichloroethylene; DDE; 1,1-Dichloro-2,2-Bis(p-chlorophenyl) ethylene; 1,1-Dichloro-2,2-di(p-chlorophenyl)ethylene; 2,2-Bis(4-chlorophenyl)-1,1-dichloroethylene; 4,4'DDE; 2,2-Bis(p-chlorophenyl)-1,1-dichloroethylene; p,p'-(Dichlorodiphenyl)-2,2-dichloroethylene; DDT dehydrochloride; 1,1-Bis(p-chlorophenyl)-2,2dichloroethylene; 1,1-Dichloro-2,2-bis(p-chlorophenyl) ethene; 1,1'-(Dichloroethenylidene)bis(4-chlorobenzene); 2,2-Bis(4-chlorophenyl)-1,1-dichloroethene;

Dichlorodiphenyldichloroethylene; 4,4'-DDEe; p,p-Dde; 1-Chloro-4-[2,2-dichloro-1-(4-chlorophenyl)vinyl]benzene; $\operatorname{DDE}(p, p$ ')

1,2,3,4,10,10-Hexachloro-6,7-epoxy-1,4,4a,5,6,7,8,8a-octahydro1,4-endo-exo-5,8-dimethanonaphthalene; exo-Dieldrin; Aldrin epoxide; Alvit 55; Dieldrex; Dielmoth; Dildrin; Dorytox; ENT-16225; HEOD; Illoxol; Insectlack; Kombi-Albertan; Moth Snub D; Octalox; Red Shield; SD 3417; Termitox; Alvit; Compd. 497; Compound 497; Dieldrite; ENT 16,225; Hexachloroepoxyoctahydro-endo,exo-dimethanonaphthalene; NCI-C00124; Panoram D-31; Quintox; Shelltox; Termitoxrm [BDH]; Murdiel; Dieldrine

Benzene, 1-chloro-2-[2,2-dichloro-1-(4-chlorophenyl)ethyl]-; Ethane, 1,1-dichloro-2-(o-chlorophenyl)-2-(p-chlorophenyl)-; o,p'-Dichlorodiphenyldichloroethane; o,p'-DDD; o,p'TDE; Chloditan; Chlodithane; CB 313; Lysodren; Mitotan; NSC-38721; 2,2-Bis(2-Chlorophenyl-4-chlorophenyl)1,1-dichloroethane; 2,4'-Dichlorodiphenyldichloroethane; 1-(o-Chlorophenyl)-1-(p-chlorophenyl)-2,2-dichloroethane; 1-(2-Chlorophenyl)-1-(4-chlorophenyl)-2,2-dichloroethane; (o,p)-DDD; Chlodithan; Ethane, 2-(o-chlorophenyl)-2-(pchlorophenyl)-1,1-dichloro-; Khlodithan; NCI-C04933; 1,1-Dichloro-2-(o-chlorophenyl)-2-(p-chlorophenyl) ethane; 1,1-Dichloro-2,2-bis(2,4'-dichlorophenyl)ethane; 2-(o-Chlorophenyl)-2-(p-chlorophenyl)-1,1-dichloroethane; 2,4'-DDD; 1,1-Dichloro-2-(p-chlorophenyl)-2-(o-chlorophenyl) ethane; 2,4'-Dichlorophenyldichlorethane; o,p-Tde; Opeprim; o,p'-DDE; 1-Chloro-2-[2,2-dichloro-1-(4-chlorophenyl)ethyl] benzene 
Table 3-1. Citations for chemical names and abbreviations.-Continued

[Final list compiled according to the National Institute of Standards and Technology (NIST) Web site (http://webbook.nist.gov/chemistry/); NIST Standard Reference Database No. 69, June 2005 release, last accessed May 9, 2008. CAS, Chemical Abstracts Service. This report contains CAS Registry Numbers ${ }^{\circledR}$, which is a Registered Trademark of the American Chemical Society. CAS recommends the verification of the CASRNs through CAS Client Services ${ }^{\mathrm{SM}}$ ]

$\begin{array}{lll}\text { Organochlorines } & \text { CAS registry number } & \text { Some alternative names }\end{array}$

Endrin

$72-20-8$

cis-nonachlor

$5103-73-1$

$o, p^{\prime}-\mathrm{DDT}$

789-02-6

$p, p$ '-DDD

$72-54-8$
2,7:3,6-Dimethanonaphth[2,3-b]oxirene, 3,4,5,6,9,9-hexachloro1a,2,2a,3,6,6a,7,7a-octahydro-, (1a $\alpha, 2 \beta, 2 \mathrm{a} \beta, 3 \alpha, 6 \alpha, 6 \mathrm{a} \beta, 7 \beta, 7 \mathrm{a} \alpha)$-; 1,4:5,8-Dimethanonaphthalene, 1,2,3,4,10,10-hexachloro6,7-epoxy-1,4,4a,5,6,7,8,8a-octahydro-, endo,endo-; Cmpd. 269; Endrex; Endricol; Experimental Insecticide 269; EN 57; Mendrin; Oktanex; SD 3419; 1,2,3,4,10,10-Hexachloro6,7-Epoxy-1,4,4a,5,6,7,8,8a-octahydro-exo-1,4-exo-5,8dimethanonaphthalene; Compd. 269; Compound 269; Endrin isomer; ENT 17,251; Hexachloroepoxyoctahydroendo,endo-dimethanonaphthalene; Hexadrin; NCI-C00157; 1,2,3,4,10,10-Hexachloro-6,7-epoxy-1,4,4a,5,6,7,8,8aoctahydro-endo-1,4-endo-5,8-dimethanonaphthalene; 1,2,3,4,10,10-Hexachloro-6,7-epoxy-1,4,4a,5,6,7,8,8aoctahydro-1,4-endo,endo-5,8-dimethanonaphthalene; Endrin mixture; 3,4,5,6,9,9-Hexachloro-1a,2,2a,3,6,6a,7,7a-octahydro2,7:3,6-dimethanonaphth(2,3-b)oxirene; Latka 269; NA 2761; Nendrin; OMS 197; Rcra waste number P051; SD 3419 Illoxol; Endrine

4,7-Methano-1H-indene, 1,2,3,4,5,6,7,8,8-nonachloro2,3,3a,4,7,7a-hexahydro-, $(1 \alpha, 2 \alpha, 3 \alpha, 3 \mathrm{a} \alpha, 4 \beta, 7 \beta, 7 \mathrm{a} \alpha)-$; 4,7-Methanoindan, $1 \alpha, 2 \alpha, 3 \alpha, 4 \beta, 5,6,7 \beta, 8,8$-nonachloro$3 \mathrm{a} \alpha, 4,7,7 \mathrm{a} \alpha$-tetrahydro-; Nonachlor, cis-

o,p'-DDT; Benzene, 1-chloro-2-[2,2,2-trichloro-1-(4chlorophenyl)ethyl]-; Ethane, 1,1,1-trichloro-2-(ochlorophenyl)-2-(p-chlorophenyl)-; 2-(2-Chlorophenyl)2-(4-chlorophenyl)-1,1,1-trichloroethane; 2,4'-DDT; 1-(o-Chlorophenyl)-1-(p-chlorophenyl)-2,2,2-trichloro ethane; Ethane, 2-(o-chlorophenyl)-2-(p-chlorophenyl)-1,1,1-trichloro-; 1,1,1-Trichloro-2-(o-chlorophenyl)-2-(p-chlorophenyl)ethane; 2,2-Bis(o,p-chlorophenyl)-1,1,1-trichloroethane; o,p-Ddt; 1-Chloro-2-[2,2,2-trichloro-1-(4-chlorophenyl)ethyl]benzene; Ddt-o,p'

1,1-Dichloro-2,2-bis(p-chlorophenyl)ethane; Benzene, 1,1'-(2,2-dichloroethylidene)bis[4-chloro-; Ethane, 1,1-dichloro-2,2-bis(p-chlorophenyl)-; p,p'-(Dichlorodiphenyl) dichloroethane; p,p'-TDE; Dichlorodiphenyldichloroethane; Dilene; DDD; TDE; 1,1-Bis(p-Chlorophenyl)-2,2dichloroethane; 1,1-Bis(4-chlorophenyl)-2,2-dichloroethane; 1,1-Dichloro-2,2-bis(4-chlorophenyl)ethane; 2,2-Bis(pchlorophenyl)-1,1-dichloroethane; 2,2-Bis(4-chlorophenyl)-1,1dichloroethane; 4,4'-DDD; ENT 4,225; NCI-C00475; Rhothane d-3; Rothane; Tetrachlorodiphenylethane; 1,1-Dichloor2,2-bis(4-chloor fenyl)-ethaan; 1,1-Dichlor-2,2-bis(4-chlorphenyl)-aethan; 1,1-Dichloro-2,2-di(4-chlorophenyl)ethane; 1,1-Dicloro-2,2-bis(4-cloro-fenil)-etano; NA 2761; OMS 1078; Benzene, 1,1'-(2,2-dichloroethylidene)bis*4-chloro-; p,p'Dichlorodiphenyl-2,2-dichloroethylene; p,p-Ddd; 1-Chloro4-[2,2-dichloro-1-(4-chlorophenyl)ethyl]benzene; p,p'-ddd; $\operatorname{DDD}(\mathrm{p}, \mathrm{p}$ ') 
Table 3-1. Citations for chemical names and abbreviations.-Continued

[Final list compiled according to the National Institute of Standards and Technology (NIST) Web site (http://webbook.nist.gov/chemistry/); NIST Standard Reference Database No. 69, June 2005 release, last accessed May 9, 2008. CAS, Chemical Abstracts Service. This report contains CAS Registry Numbers ${ }^{\circledR}$, which is a Registered Trademark of the American Chemical Society. CAS recommends the verification of the CASRNs through CAS Client Services ${ }^{\text {SM }}$ ]

\begin{tabular}{lcc} 
& Organochlorines & CAS registry number \\
\hline$p, p$ '-DDT & $50-29-3$
\end{tabular}

p,p'-DDT; Chlorophenothane; $\alpha, \alpha$-Bis(p-chlorophenyl)$\beta, \beta, \beta$-trichlorethane; $\mathrm{p}, \mathrm{p}$-Dichlorodiphenyltrichloroethane; Aavero-extra; Agritan; Arkotine; Azotox; Azotox M-33; Bosan supra; Bovidermol; Chlorphenothan; Chlorphenotoxum; Citox; Clofenotan; Clofenotane; Deoval; Detox; Detoxan; Dibovin; Dicophane; Dodat; Dykol; DDT; Estonate; Ethane, 1,1,1-Trichloro-2,2bis(p-chlorophenyl)-; Ethane, 1,1,1-trichloro-2,2-bis(4chlorophenyl)-; ENT-1506; Gesafid; Gesarol; Ivoran; Mutoxan; Neocid; Neocidol, Solid; Parachlorocidum; Pentachlorin; Penticidum; PEB1; Trichlorobis(4' Chlorophenyl)ethane; Zerdane; 1,1-Bis(p-chlorophenyl)2,2,2-trichloroethane; 1,1,1-Trichloro-2,2-bis(p-chlorophenyl) ethane; 1,1,1-Trichloro-2,2-bis(4,4'-dichlorodiphenyl) ethane; 2,2-Bis(p-chlorophenyl)-1,1,1-trichloroethane; 4,4'-Dichlorodiphenyltrichloroethane; 4,4'-DDT; 1,1-Bis(4chlorophenyl)-2,2,2-trichloroethane; 1,1,1-trichloro-22-bis(4-chlorophenyl)ethane; Anofex; Chlorphenotane; Dichlorodiphenyltrichloroethane; Didigam; Didimac; Genitox; Guesarol; Gyron; Ixodex; Kopsol; Neocidol; NCI-C00464; Pentech; Ppzeidan; Rukseam; Santobane; Tafidex; Trichlorobis(4-chlorophenyl)ethane; Zeidane; 1,1,1-Trichloor2,2-bis(4-chloor fenyl)-ethaan; 1,1,1-Trichlor-2,2-bis(4-chlorphenyl)-aethan; 1,1,1-Trichloro-2,2-bis(p-chlorophenyl)ethane chlorophenothane; 1,1,1-Trichloro-2,2-di(4-chlorophenyl) ethane; 1,1,1-Tricloro-2,2-bis(4-cloro-fenil)-etano; Chlorophenothan; Chlorophenotoxum; Dedelo; Dibovan; Diphenyltrichloroethane; ENT 1,506; Gesapon; Gesarex; Guesapon; Havero-extra; Hildit; Micro ddt 75; Mutoxin; NA 2761; OMS 16; R50; Rcra waste number U061; Tech ddt; Penticide; Zithiol; p,p-DDT; 2,2,2-Trichloro-1,1-bis(4chlorophenyl)ethane; $\mathrm{p}, \mathrm{p}$ '-Dichlorodiphenyltrichloromethylm ethane; 1, 1-Dichloro-2-(o-chlorophenyl)-2-(p-chlorophenyl) ethane; 1, 1-Dichloro-2,2-bis(2,4'-dichlorophenyl)ethane; 1,1'-(2,2,2,-Trichloroethylidene)bis[4-chlorobenzene]; 2-(o-Chlorophenyl)-2-(p-chlorophenyl)-1,1-dichloroethane; De De Tane; Dichlorodiphenyltrichlorethane; Dicophaner; Dnsbp; Ethane, 1, 1-dichloro-2-(o-chlorophenyl)-2-(p-chlorophenyl)-; Ethane, 2-(o-chlorophenyl)-2-(p-chlorophenyl)-1,1-dichloro-; Geusapon; 1-Chloro-4-[2,2,2-trichloro-1-(4-chlorophenyl) ethyl]benzene; 1,1-bis(p-Chlorophenyl)-2,2,2-trichIoroethane; $\operatorname{DDT}(\mathrm{p}, \mathrm{p}$ ') 
Table 3-1. Citations for chemical names and abbreviations.-Continued

[Final list compiled according to the National Institute of Standards and Technology (NIST) Web site (http://webbook.nist.gov/chemistry/); NIST Standard Reference Database No. 69, June 2005 release, last accessed May 9, 2008. CAS, Chemical Abstracts Service. This report contains CAS Registry Numbers ${ }^{\circledR}$, which is a Registered Trademark of the American Chemical Society. CAS recommends the verification of the CASRNs through CAS Client Services ${ }^{\mathrm{SM}}$ ]

Organochlorines CAS registry number $\quad$ Some alternative names

mirex

$2385-85-5$
1,3,4-Metheno-2h-cyclobuta[c,d]pentalene, dodecachlorooctahydro- with other names: Dodecachlorooctahydro-1,3,4-metheno-2H-cyclobuta[cd] pentalene; 1,3,4-Metheno-1H-cyclobuta[cd]pentalene, 1,1a,2,2,3,3a,4,5,5,5a,5b,6-dodecachlorooctahydro-; CG-1283; Dechloran Plus; Dechlorane; Dechlorane Plus; Dechlorane Plus 515; Dechlorane 4070; Dechlorane 515; ENT 25,719; GC 1283; Hexachlorocyclopentadiene Dimer; Paramex; Pentacyclodecane, dodecachloro-; Perchlorodihomocubane; Perchloropentacyclodecane; Perchloropentacyclo[5.2.1.0( sup2,6).0(sup3,9).0(sup5,8)]decane; 1,3-Cyclopentadiene, 1,2,3,4,5,5-hexachloro-, dimer; Bichlorendo; Cyclopentadiene, hexachloro-, dimer; Decane,perchloropentacyclo-; Dodecachlorooctahydro-1,3,4-metheno-1H-cyclobuta(cd) pentalene; Dodecachloropentacyclodecane; Dodecachlorop entacyclo(3,3,2,0(sup2,6),o(sup3,9),0(sup7,10))decane; Hrs 1276; NCI-C06428; Perchloropentacyclo(5.2.1.02,6.03,9.05,8) decane; 1,3,4-Metheno-1H-cyclobuta(cd)pentalene, dodecachlorooctahydro-; 1,1a,2,2,3,3a,4,5,5,5a,5b,6Dodecachlorooctahydro-1,3,4-metheno-1H-cyclobuta(cd) pentalene; Dodecachloropentacyclo(3.2.2.02,6,03,9,05,10) decane; Ferriamicide; 1,2,3,4,5,5-Hexachloro-1,3cyclopentadiene dimer; Mirex

\begin{tabular}{|c|c|c|}
\hline Polycyclic aromatic hydrocarbons & CAS registry number & Some alternative names \\
\hline naphthalene & $91-20-3$ & $\begin{array}{l}\text { Albocarbon; Dezodorator; Moth flakes; Naphthalin; Naphthal } \\
\text { Naphthene; Tar camphor; White tar; Camphor tar; Moth bal } \\
\text { Naftalen; NCI-C52904; Mighty 150; Mighty rd1; Napthaler } \\
\text { molten; Rcra waste number U165; UN 1334; UN } 2304\end{array}$ \\
\hline 2-methylnaphthalene & $91-57-6$ & $\begin{array}{l}\text { Naphthalene, 2-methyl-; } \beta \text {-Methylnaphthalene; } \\
\text { 2-Methylnaphthalene; 2-methyInaphthalene; Methyl-2- } \\
\text { naphthalene }\end{array}$ \\
\hline 1-methylnaphthalene & $90-12-0$ & $\begin{array}{l}\text { Naphthalene, 1-methyl-; } \alpha \text {-Methylnaphthalene; } \\
\text { 1-Methylnaphthalene; Methyl-1-naphthalene }\end{array}$ \\
\hline biphenyl & $92-52-4$ & $\begin{array}{l}\text { 1,1'-Biphenyl; Bibenzene; Diphenyl; Phenylbenzene; } \\
\text { 1,1'-Diphenyl; Lemonene; Phenador-X; PHPH; Xenene; } \\
\text { Carolid al; Tetrosin ly; 1,1-Biphenyl }\end{array}$ \\
\hline 2,6-dimethylnaphthalene & $581-42-0$ & Naphthalene, 2,6-dimethyl \\
\hline acenaphthalene & $208-96-8$ & Acenaphthylene; Cyclopenta[de]naphthalene; \\
\hline acenaphthene & $83-32-9$ & $\begin{array}{l}\text { Acenaphthylene, 1,2-dihydro-; Peri-Ethylenenaphthalene; } \\
\text { Naphthyleneethylene; 1,2-Dihydroacenaphthylene; } \\
\text { 1,8-Ethylenenaphthalene; acenaphtene }\end{array}$ \\
\hline 2,3,5-trimethylnaphthalene & $2245-38-7$ & $\begin{array}{l}\text { Naphthalene, 2,3,5-trimethyl-; 1,6,7-Trimethylnaphthalene; } \\
\text { 2,3,5-Trimethylnaphthalene }\end{array}$ \\
\hline fluorene & $86-73-7$ & $\begin{array}{l}\text { 9H-Fluorene; o-Biphenylenemethane; Diphenylenemethane; } \\
\text { Methane, diphenylene-; 2,2'-Methylenebiphenyl; } \\
\text { 2,3-Benzindene; o-Biphenylmethane }\end{array}$ \\
\hline
\end{tabular}


Table 3-1. Citations for chemical names and abbreviations.-Continued

[Final list compiled according to the National Institute of Standards and Technology (NIST) Web site (http://webbook.nist.gov/chemistry/); NIST Standard Reference Database No. 69, June 2005 release, last accessed May 9, 2008. CAS, Chemical Abstracts Service. This report contains CAS Registry Numbers ${ }^{\circledR}$, which is a Registered Trademark of the American Chemical Society. CAS recommends the verification of the CASRNs through CAS Client Services $\left.{ }^{\text {SM }}\right]$

\section{Polycyclic aromatic hydrocarbons}

dibenzothiophene

phenanthrene

anthracene

1-methylphenanthrene

fluoranthene

206-44-0

pyrene

129-00-0

1,2-benzathracene

56-55-3

chrysene

218-01-9

benzo(b)fluoranthene

205-99-2

benzo(k)fluoranthene

207-08-9

benzo(e)pyrene

192-97-2

benzo(a)pyrene

50-32-8

perylene
198-55-0

\section{Some alternative names}

[1,1'-Biphenyl]-2,2'-diyl sulfide; Dibenzo[b,d]thiophene; Diphenylene sulfide; 2,2'-Biphenylylene sulfide;

9-Thiafluorene; $\alpha$-Thiafluorene

Phenanthren; Phenanthrin; Phenantrin

Anthracin; Green Oil; Paranaphthalene; Tetra Olive N2G; Anthracene oil; p-Naphthalene; Anthracen; Coal tar pitch volatiles:anthracene; Sterilite hop defoliant

Phenanthrene, 1-methyl-

Benzene, 1,2-(1,8-naphthalenediyl)-; Benzo[jk]fluorene; Idryl; 1,2-(1,8-Naphthylene)benzene; Benzo[jk]fluorene, idryl; Benzene, 1,2-(1,8-naphthylene)-; 1,2-Benzacenaphthene; 1,2-(1,8-Naphthalenediyl)benzene; Rcra waste number U120; 1,2-(1,8-Naphthalene)benzene; FA; Fluoranthrene

$\beta$-Pyrene; Benzo[def]phenanthrene; Pyren; Coal tar pitch volatiles:pyrene

Benzo(a)anthracene; Benzanthracene; Benzanthrene; Benzoanthracene; Benzo[a]anthracene; Benzo[b] phenanthrene; Tetraphene; 1,2-Benzanthracene; 1,2-Benzanthrene; 1,2-Benzoanthracene; 1,2-Benz[a] anthracene; 2,3-Benzophenanthrene; BA; Naphthanthracene; 1,2-Benzanthrazen; 2,3-Benzphenanthrene; Rcra waste number U018

Benzo[a]phenanthrene; 1,2-Benzophenanthrene; 1,2-Benzphenanthrene; Benz(a)phenanthrene; 1,2,5,6-Dibenzonaphthalene; Rcra waste number U050; Crysene

Benz[e]acephenanthrylene; Benzo[b]fluoranthene; Benzo[e] fluoranthene; 2,3-Benzofluoranthrene; benzo[e] acephenanthrylene; $\mathrm{B}(\mathrm{b}) \mathrm{F}$; 2,3-Benzofluoranthene; 4,5-Benzofluoranthene; 2,3-Benzfluoranthene; 3,4-benzfluoranthene; 3,4-benzofluoranthene; Benz[b] fluoranthene

Dibenzo[b,jk]fluorene; 11,12-Benzofluoranthene; 2,3,1',8'-Binaphthylene; 8,9-Benzofluoranthene

4,5-Benzopyrene; 4,5-Benzpyrene; B(e)P; Benzo(1)pyrene; Benz(e)pyrene; 9,10-Benzpyrene

Benz[a]pyrene; 1,2-Benzpyrene; 3,4-Benzopyrene; 3,4-Benzpyrene; 3,4-Benz[a]pyrene; 6,7-Benzopyrene; Benzo[ $\alpha]$ pyrene; Benzo[d,e,f]chrysene; B(a)P; BP; 3,4-Benzopirene; 3,4-Benzpyren; 3,4-BP; Rcra waste number U022; Benzopyrene

Peri-Dinaphthalene; Dibenz[de,kl]anthracene; Perilene 
Table 3-1. Citations for chemical names and abbreviations.-Continued

[Final list compiled according to the National Institute of Standards and Technology (NIST) Web site (http://webbook.nist.gov/chemistry/); NIST Standard Reference Database No. 69, June 2005 release, last accessed May 9, 2008. CAS, Chemical Abstracts Service. This report contains CAS Registry Numbers ${ }^{\circledR}$, which is a Registered Trademark of the American Chemical Society. CAS recommends the verification of the CASRNs through CAS Client Services ${ }^{\mathrm{SM}}$ ]

\section{Polycyclic aromatic hydrocarbons}

indeno(1,2,3-cd)pyrene

1,2,5,6-dibenzanthracene

benzo(g,h,i)perylene

C1-naphthalenes

C2-naphthalenes

C3-naphthalenes

C4-naphthalenes

C1-fluorenes

C2-fluorenes

C3-fluorenes

C1-phenanthrenes

C2-phenanthrenes

C3-phenanthrenes

C1-dibenzothiophenes

C4-phenanthrenes

C2-dibenzothiophenes

C3-dibenzothiophenes

C1-fluoranthenes+C1-pyrene

C1-chrysenes

C2-chrysenes

C3-chrysenes

C4-chrysenes
$53-70-3$

\section{CAS registry number}

193-39-5

53-70-3

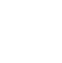

N/A

N/A

N/A

N/A

N/A

N/A

N/A

N/A

N/A

N/A

N/A

N/A

N/A

N/A

N/A

N/A

N/A

N/A

\section{Some alternative names}

o-Phenylenepyrene; Indenopyrene; 1,10-(o-Phenylene)pyrene; 1,10-(1,2-Phenylene)pyrene; 2,3-(o-Phenylene)pyrene; IP; 2,3-Phenylenepyrene; 1,10-(ortho-Phenylene)pyrene; Rcra waste number U137

Dibenz(a,h)anthracene; Dibenzo[a,h]anthracene; DBA; 1,2:5,6-Benzanthracene; 1,2:5,6-Dibenzanthracene; 1,2:5,6-Dibenzoanthracene; 1,2,5,6-Dibenzanthracene; Db(a,h)a; Dibenz(a,h)antracene; 1,2,5,6-Dibenzanthraceen; 1,2:5,6-Dibenz(a)anthracene; 1,2,5,6-DBA; Rcra waste number U063

191-24-2 Benzo-1,12-perylene; 1,12-Benzoperylene; 1,12-Benzperylene

N/A 
Table 3-1. Citations for chemical names and abbreviations.-Continued

[Final list compiled according to the National Institute of Standards and Technology (NIST) Web site (http://webbook.nist.gov/chemistry/); NIST Standard Reference Database No. 69, June 2005 release, last accessed May 9, 2008. CAS, Chemical Abstracts Service. This report contains CAS Registry Numbers ${ }^{\circledR}$, which is a Registered Trademark of the American Chemical Society. CAS recommends the verification of the CASRNs through CAS Client Services ${ }^{\text {SM }}$ ]

\begin{tabular}{llc}
\multicolumn{1}{c}{ Inorganic compounds } & CAS registry number & Some alternative names \\
\hline aluminum & N/A & $\mathrm{Al}$ \\
arsenic & N/A & $\mathrm{As}$ \\
barium & N/A & $\mathrm{Ba}$ \\
boron & N/A & $\mathrm{B}$ \\
cadmium & N/A & $\mathrm{Cd}$ \\
chromium & N/A & $\mathrm{Cr}$ \\
copper & N/A & $\mathrm{Cu}$ \\
iron & N/A & $\mathrm{Fe}$ \\
mercury & N/A & $\mathrm{Hg}$ \\
magnesium & N/A & $\mathrm{Mg}$ \\
manganese & N/A & $\mathrm{Mn}$ \\
nickel & N/A & $\mathrm{Ni}$ \\
lead & N/A & $\mathrm{Pb}$ \\
selenium & N/A & $\mathrm{Se}$ \\
strontium & N/A & $\mathrm{Sr}$ \\
vanadium & N/A & $\mathrm{V}$ \\
zinc & N/A & $\mathrm{Zn}$ \\
\hline
\end{tabular}




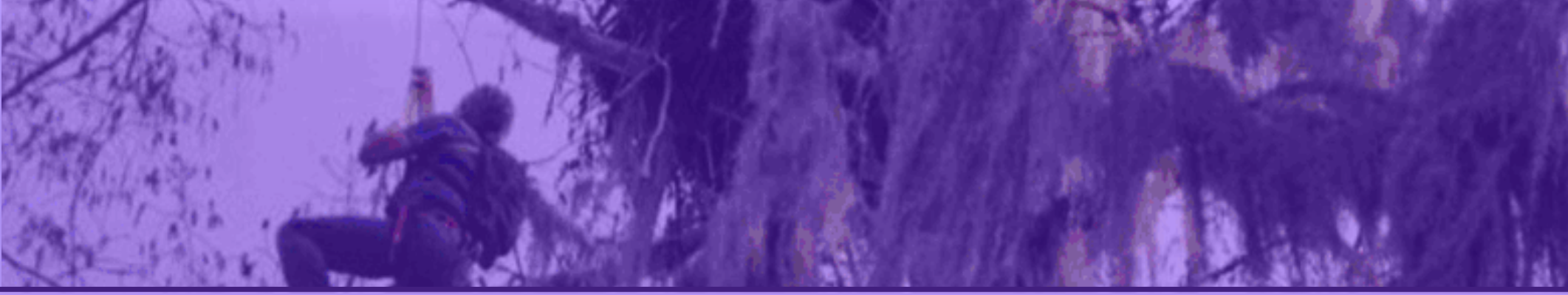



